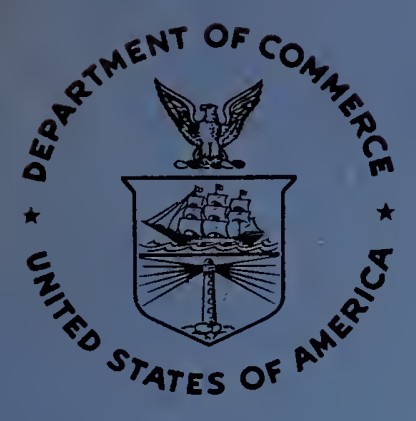

Water Quality and Molluscan Shellfish: An Overview of the Problems and the Nature of Appropriate Federal Laws

Washington, D.C.

March 1977

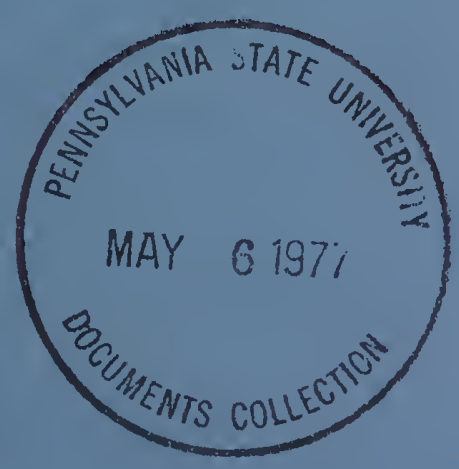

U.S. DEPARTMENT OF COMMERCE

National Oceanic and Atmospheric Administration National Marine Fisheries Service 

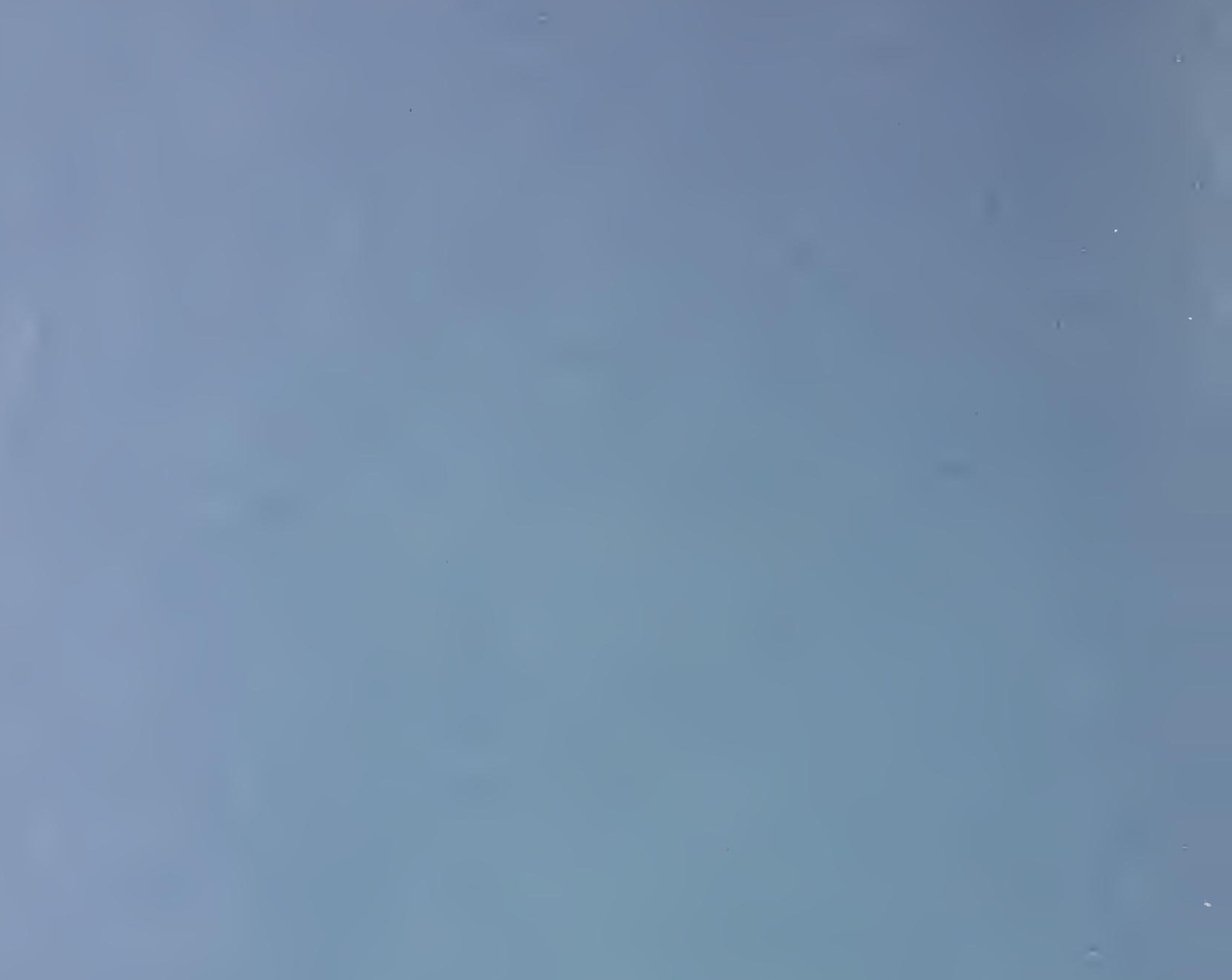

1

$y^{2}=$ 


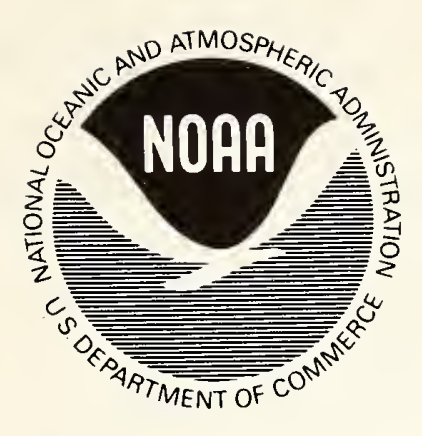

\section{Water Quality and}

Molluscan Shellfish:

An Overview of the

\section{Problems and the
Nature of Appropriate Federal Laws}

Conducted in cooperation with, and under contract to, The National Marine Fisheries Service, Washington, D.C.

Principal Investigator

David R. Zoellner

The views and recommendations contained in this report are not necessarily those of The National Marine Fisheries Service

Stanford Research Institute

Center for Resource and

Environmental Systems Studies

1611 North Kent Street

Arlington, Virginia 22209

\section{U.S. DEPARTMENT OF COMMERCE} Juanita M. Kreps, Secretary

National Oceanic and Atmospheric Administration

Robert M. White, Administrator

National Marine Fisheries Service

Robert W. Schoning, Director 
Without the assistance in various ways of a number of people, this report would not have been produced. Principal among these were the efforts of Mr. Allen Zink and Mr. Cornelius Kelly. Mr. Zink is an attorney with SRI and he responded admirably to the challenge of evaluating the effectiveness of Federal law. Mr. Kelly acted as a consultant to SRI, bringing to the project an expertise gained through many years of experience acquired directing State and Federal shellfish programs. Many long hours, nights, and weekends were contributed in travel, interviews, drafting, reviewing, correcting, and recorrecting by several SRI staff: Mr. Michael Sadler, Mrs. Ellen Burr, Ms. Gail Patelcuis, Ms. Julie Bishop and by temporary staff: Ms. Diane White and Mr. William Dix. Helpful review and comments were provided by senior SRI staff: Mr. Charles Hulburt, Mr. Warren Berning, and $\mathrm{Mr}$. James Bick. Principal typing assistance was provided by Ms. Sonya Tenney, Mrs. Sally Miller, Ms. Sharon Hale, Mrs. Cynthia Brathwaite, and Mrs. Joan Hill. Last and by no means least was the very significant review, coordination, and editing effort provided by Mr. James Spencer of SRI.

Overall review and collaboration on specific sections were provided by NMFS staff. 
ACKNOWLEDGMENTS . . . . . . . . . . . . . . . . . . . ii

LIST OF TABLES. . . . . . . . . . . . . . . . . . vii

GLOSSARY. . . . . . . . . . . . . . . . . . . ix

I INIRODUCTION. . . . . . . . . . . . . . . . 1

A. Viability of Molluscan Shellfish Resources . . 1

B. Water Quality. . . . . . . . . . 1

C. Laws and Their Effectiveness . . . . . . . 2

II PURPÓSE AND APPROACH. . . . . . . . . . . . . 4

III POLLUTION AND OTHER IMPACTS ON RESOURCES. . . . . . 6

A. Effects of Natural Phenomena . . . . . . 6

1. Hurricanes, Floods, and Strong Winds . . . 6

2. Uncontrolled Runoff. . . . . . . . 8

3. Diseases and Predation ........ . 11

4. Red Tides and Other Plankton Blooms. . . . 13

B. Effects of Man's Activities. . . . . . . 15

1. Agricultural and Silvicultural Activitiy . 15

a. Disease Organisms. . . . . . . 15

b. Pesticides.......... . . . 17

2. Industrial Activity. . . . . . . . . 18

a. Pesticides and Chemical Manufacturing. 19

b. Industrial Waste Processing and Discharges . . . . . . . . . . 21

c. Power Generation . . . . . . . . 22

3. Municipal Activities . . . . . . . 25

a. Construction and Maintenance Activities . . . . . . . . . 
b. Storm and Wastewater Collection. . .

c. Sewage and Wastewater Treatment. . .

d. Chlorination and Other Forms of

e. Solid Waste Disposal . . . . . . . 30

4. Coastal Zone Development . . . . . . 30

a. Sediments. . . . . . . . . 31

b. Wetland Destruction and Hydrologic

c. Discharges .. . . . . . . . 33

5. Water Resource Development . . . . . 35

a. Channelization . . . . . . . 36

b. Water Impoundments . . . . . . 37

c. Interbasin Transfer. . . . . . . 38

d. Effectiveness of Impact Controls . . . 38

6. Long-Term Effects of Chemicals and Their Residuals............ . . . 39

IV COMPETITIVE USES--CONFLICTS AND PRESSURES . . . . . 42

A. Conflicts Between Man and Nature . . . . . 43

B. Commercial-Recreational Use Conflicts. . . . . 44

C. Institutional Conflicts. . . . . . . . . 44

V GROWING WATER CLASSIFICATION, TRENDS, EVALUATION VALUE LOSSES, AND POTENTIAL INCREASES IN PRODUCTION 45

A. Growing Water Classification. . . . . . . 45

B. Trends in Closures. . . . . . . . . . 48

C. Evaluation of Trends in Water Quality . . . . 48

D. Estimated Value Losses Resulting from Closure of Contaminated Water to Harvesting. . . . . . 50

1. General . . . . . . . . . . . 50

2. Losses of Resource and Habitat. . . . . 52

E. Potential Increases in Domestic Catch . . . . 52

F. The National Shellfish Register . . . . . . 54

G. Summary . . . . . . . . . . . . . . 55 
A. Federal Water Pollution Control Act Amendments of 1972 (FWPCA). . . . . . . .

1. Water Quality Standards . . . . . .

2. Effluent Limitations and the National Pollutant Discharges Elimination System (NPDES)

3. Marine Sanitation Devices . . . . . .

4. Disposal of Dredging Spoil. . . . . .

5. Toxic Discharges. . . . . . . . .

6. Municipal Sewage Treatment. . . . . .

7. Stormwater Runoff . . . . . . . . .

a. Urban Runoff. . . . . . . . . .

b. Agricultural Wastes . . . . . .

8. Areawide Planning . . . . . . . . .

9. P.L. 92-500 Summary . . . . . . .

B. River and Harbor Act of 1899. . . . . . .

C. Marine Protection, Research, and

Sanctuaries Act of 1972, as Amended . . . . .

D. Fish and Wildlife Coordination Act of 1958. . .

E. Coastal Zone Management Act of 1972, the Amendments of 1976. . . . . . . . . . .

F. The Submerged Lands Act and the Outer Continental Shelf Lands Act . . . . . . .

G. Deepwater Port Act of 1974. . . . . . .

H. Fishery Conservation and Management Act of 1976 . . . . . . . . . . . . .

I. The National Environmental Policy Act of 1969 and the Estuarine Areas Act. . . . . .

J. The Water Resources Planning Act. . . . . . 
K. Research and Development Laws . . . . . . . 94

L. Summary . . . . . . . . . . . . 95

VII CONCLUSIONS AND SUGGESTED OPTIONS . • . . • . . . 99

A. Research Needs. . . . . . . . . . 99

1. Conclusion. . . . . . . . . . 99

2. Option. . . . . . . . . . . 101

B. Fish and Wildlife Coordination. . . . . . 102

1. Conclusion. . . . . . . . . . 102

2. Option. . . . . . . . . . . . 102

C. Shellfish Growing Waters. . . . . . . . 102

1. Conclusion. . . . . . . . . . 102

2. Option. . . . . . . . . . . . 103

D. Water Quality Control Laws. . . . . . . 103

1. Conclusion. . . . . . . . . . . 103

2. Option. . . . . . . . . . . . 103

E. The Coasta1 Zone Management Act of 1972 . . . 103

1. Conclusion. . . . . . . . . . . 103

2. Option. . . . . . . . . . . 103

F. Consistent Agency Jurisdiction. . . . . . . 104

1. Conclusion. . . . . . . . . . . 104

2. Option. . . . . . . . . . . 106

APPENDICES

A. CASE STUDIES. . . . . . . . . . . . A A-1

B. LEgISLATION . . . . . . . . . . . . B B-2

C. CONTACTS AND INTERVIEWS . . . . . . . . . . . C-1

D. BIBLIOGRAPHY. . . . . . . . . . . . . D D-1 
Table 1 Calculated Quantities of Pollutants that Would Enter Receiving Waters--Hypothetical City

Table 2 Industrial Discharges by Industry Group. • . . 19

Table $3^{\circ}$ Acid Production, by Kind--1960 to 1973 . . . 20

TAble 4 Coastal Zone Activities and Direct Impacts. . . 32

Table 5 Amounts of U.S. Petroleum and Petroleum

Hydrocarbon Released into the Marine

Environment

Table 6 Net changes in Shellfish Growing Water Areas Between 1966 and 1976. . . . . . . . 51

Table 7 Summary of Value Loss--A1l Species . . . . 52

Table 8 Estimated Potential Increase in Domestic

Catch (1972-1985) by Species and State

Due to Impact of P.L. 92-500 on Water Quality

and Therefore Biological Productivity. . . . . 53

Table 9 NPDES Permit Program ․ . • • . • • . 61

Table 10 State-By-State Breakdown of NPDES Permits

Issued by States and EPA Program Status for

the 23 Coastal States, September 30, 1976 • • 65

Table 11 EPA Guidelines for Secondary Treatment . • $\quad$ - 71

Table 12 National Marine Fisheries Service Environmental Assessment Division Caseload

Responses 
Digitized by the Internet Archive in 2012 with funding from

LYRASIS Members and Sloan Foundation

http://www.archive.org/details/waterqualitymoll00stan 
BAT

BOD

BPT

COD

COE

CZMA

EHA

EIS

EPA

FDA

FEPCA

FIFRA

FWCA

FWPCA

GPD

HEW

HUD

MPN

MSX

NEPA

NMFS

NOAA

NPDES

best available control technology

biochemical oxygen demand

best practible control technology

chemical oxygen demand

Army Corps of Engineers

Coastal Zone Management Act

Environmental Health Administration

environmental impact statement

Environmental Protection Agency

Food and Drug Administration

Federal Environmental Pesticide Control Act

Federal Insecticide, Fungicide, and Rodenticide Act

Fish and Wildlife Coordination Act

Federal Water Pollution Control Act

ga11ons per day

Department of Health, Education, and Welfare

Department of Housing and Urban Development

most probable number

a lethal and highly infectious fungal disease of shellfish, especially oysters (Identification uncertain--Haplosporidium sp., Mackin; Minchinia nelsoni, NMFS)

National Environmental Policy Act

National Marine Fisheries Service

National Oceanic and Atmospheric Administration

National Pollution Discharge Elimination System 


$\begin{array}{ll}\text { NRDC } & \text { Natural Resources Defense Council } \\ \text { OPEC } & \text { Organization of Petroleum Exporting Countries } \\ \text { PCBs } & \text { polychlorinated biphenyls } \\ \text { Ppb } & \text { parts per billion } \\ \text { PPm } & \text { parts per million } \\ \text { PSP } & \text { paralytic shellfish poisoning } \\ \text { SRI } & \text { Stanford Research Institute } \\ \text { STP } & \text { sewage treatment plant } \\ \text { SWCB } & \text { State Water Control Board } \\ \text { USDA } & \text { Department of Agriculture } \\ \text { VIMS } & \text { Virginia Institute of Marine Science }\end{array}$


This study was undertaken by Stanford Research Institute (SRI) under contract from the National Marine Fisheries Service (NMFS), National Oceanic and Atmopheric Administration (NOAA), Department of Commerce, pursuant to Coastal Zone Management Act Amendments of 1976, Sec. 16. The purpose of the study was to review the effect of water quality on molluscan shellfish and the impact of Federal laws concerning water quality.

This report discusses the threats to the shellfish acreage open or closed to recreational and commercial harvesting, the availability of the shellfish resource, and the closure of harvestable areas in the interest of public health and the general health of the resource. The report primarily addresses questions related to oysters, clams and mussels, since these are the principal molluscan shellfish consumed raw or partially cooked.

Unless so indicated, no differentiation is intended in this report between wild, planted or controlled shellfish stocks (aquaculture) where there are references to water quality as it effects resources, production, planting, seed sources, shellfish beds or other aspects of reproduction, growth or harvest. Water quality requirements for reproduction, growth and general vigor of a given shellfish species, its harvest and use, are considered to be the same whether stocks are in open or controlled waters.

In the evaluation of the findings, relevant laws were reviewed to consider their effectiveness. Pertinent enforcement, abatement, and advisory programs were reviewed as to their effect, positive or negative, on shellfish resources.

\section{A. Viability of Molluscan Shellfish Resources}

Threats to the continued viability of molluscan shellfish resources are a matter of mounting concern among the public, various Federal, state, and local agencies, and the shellfish industry. Public health, discussed below, and economic and social impacts are the questions of prime importance in this context. The rate at which shellfish growing waters are closed to harvesting has been decreasing in recent years; however, the decrease in resource productivity continues unabated. This results in loss of employment in the shellfish industry, and in other economic consequences such as higher prices to the consumer. Damage to molluscan shellfish and their habitat results in changes that are reversible by man, nature, or both. However, some changes are irreversible and the resource is lost beyond recovery.

\section{B. Water Quality}

An important aspect of the study of water quality is the specific needs of the molluscan shellfish organism for its survival and propagation. Chief among these needs are a suitable supply of food, adequate oxygen for respiration, a habitat relatively free of silting material, and a suitable range of temperature, salinity, and chemical parameters. These conditions are 
often interfered with or controlled, to a greater or lesser extent, by man's activities in the environment. Interference may also be the result of natural disasters, such as heavy runoff, floods, or hurricanes.

Man-caused water quality impacts on molluscan shellfish resources can be divided into two major categories. The first can be considered as water quality changes which generally do not kill the shellfish resource but may contaminate it so that it cannot be safely used for human food, or affect its flavor so that it is not desirable for human consumption. Mollusks that are contaminated with pathogenic organisms from sewage or other sources, pesticides, heavy metals or other toxic substances, are not suitable for human consumption. Contamination by petroleum derivatives, copper or other chemicals which cause undesirable tastes in shellfish significantly affects their marketability.

The second category of man-caused water quality impacts are those resulting in habitat changes which significantly alter the viability of the resource or even its continued existence. A positive habitat alteration such as improved oxygen, nutrient, salinity, temperature or water circulation conditions could increase the productivity of shellfish. Conversely, reductions in vaibility or elimination of the population can be caused directly or indirectly by toxic pollutants, oxygen deficiencies, or other conditions which some organisms may not tolerate during certain phases of their life cycles. Physical, chemical or biological alteration of the habitat through construction of dams, reservoirs, channels, levees, jetties, or urban areas, destroy organisms or prevent their reproduction. Further, changes in salinity, temperature, nutrient or other water quality parameters can favor the distribution of disease and predator organisms.

The sanitary quality of shellfish growing areas is by far the principal factor that currently influences the quality of molluscan shellfish as a food product. Shellfish meats are often consumed raw, or only partially cooked, and with few exceptions the entire animal is consumed. Filter feeding mollusks pump prodigious quantities of water, entrapping plankton and some of the suspended and dissolved inert material from water passed over the gills. They are relatively indiscriminating in their retention of pathogeus in addition to harmless bacteria and viruses. Of no less concern are the unknowns surrounding the many toxic compounds such as pesticides, other synthetic chemicals, heavy metals, and petroleum and distillates found in the environment. The uptake rate of these materials, the physiological consequences, the storage and purging properties, and the carcinogenic qualities are important for both mollusk and man.

Case studies of U.S. estuarine areas that exemplify these problems are presented in Appendix A.

C. Laws and Their Effectiveness

Laws that relate to water quality and the molluscan shellfish industry fall into four general categories: (1) Policy and goals, (2) research and development, (3) standards and enforcement, and (4) planning and management. 
These laws are reviewed individually for their effectiveness in dealing with water quality problems encountered in the study. They are also reviewed collectively to determine whether additional legislation would be beneficial.

The four laws that have the greatest impact on water quality and molluscan shellfish resources are:

(1) Federal Water Pollution Control Act Amendments of 1972 (FWPCA).

(2) Rivers and Harbors Act of 1899.

(3) Marine Protection, Research, and Sanctuaries Act of 1972.

(4) Fish and Wildlife Coordination Act of 1958.

The effectiveness of these laws is discussed in Section VI-A through VI-D, and the laws are more extensively described in Appendix B. 
The purpose of this study is to examine the quality of waters in representative commercially important molluscan shellfish growing areas, identify leading threats to the health of the resource and to the consumer, examine the causes of these problems, and review the relevant Federal laws for their effectiveness in addressing the problems. Key states were chosen for intensive investigation. Coastal areas of Maine, New York, New Jersey, Maryland, Virginia, Louisiana, and Washington were selected because, taken together, they are the main oyster, clam, and mussel producing states and represent the overall ecological situation along the coastlines of the United States.

Initial interviews were conducted at the headquarters and regional offices of the Food and Drug Administration (FDA), the Environmental Protection Agency (EPA), the Army Corps of Engineers (COE), and NMFS. During the interviews, an attempt was made to validate the selection of key states and to determine whether additional states should be studied. In the selection of individuals to interview, differences in the functions of state and Federal agencies were taken into consideration. Agencies and officials of the Federal Government have their counterparts in the state governments, but their roles differ. The role of the Federal agencies is that of providing overview, policy, direction, and funding, while the state agencies have a more direct role in providing means for carrying out enforcement, monitoring, and conservation activities. However, several Federal agencies are directly involved in regulatory, monitoring, and conservation activities.

Persons interviewed in the Federal agencies, and later, in the states, included:

(1) Administrators having direct responsibility for the overall direction of programs and for coordination of their efforts with other programs.

(2) Specialists responsible for the implementation of specific program components.

The specific program areas and the agencies responsible for these programs included:

(1) Enforcement compliance--FDA, EPA, COE, and the state agencies with counterpart roles.

(2) Permits--EPA, FDA, COE, and the state agencies with counterpart roles.

(3) Standards and criteria--EPA, FDA, and the state agencies with counterpart roles.

(4) Environmental assessment--EPA, COE, NMFS, FWS, and the state agencies with counterpart roles. 
(5) Conservation--NMFS, FWS, and the state agencies with counterpart roles.

A number of key personnel from the molluscan shellfish industry were interviewed because of their direct concern with this study. The molluscan industry played a significant role in initiating action for developing the National Shellfish Sanitation Program, a voluntary arrangement between representatives from industry and Federal and state governments to assure safe shellfish production and processing.

In addition to its use of interviews, the study team also obtained information on environmental effects from impact statements, water quality studies, resource surveys of approved and prohibited areas, and related reports and documents. The information acquired from both the interviews and the literature was divided into two general categories: (1) Information having to do with the administrative and technical programs responsible for implementing the law, and (2) information concerning the effects, positive or negative, of the law on the quality of shellfish growing areas and the extent of shellfish resources. Information concerning programs was obtained from organization charts, statements of mission and function, policy statements, rules and regulations, and budgetary data. 
A variety of factors affect the molluscan shellfish habitat. Some of these are the result of natural phenomena, but the major threats are the consequences of man's activities. This section discusses the effects of nature and the activities of man that have the greatest impact on the viability of estuarine waters.

\section{A. Effects of Natural Phenomena}

1. Hurricanes, Floods, and Strong Winds

Hurricanes, floods, and strong winds cause changes that can have significant effects on mollusks, depending, of course, on the degree of intensity of the causative agent.

The physical power of high winds and the wave action of hurricanes can cause alterations in beaches, sand bars, weltands, and molluscan shellfish beds ranging from minor alterations to total destruction. Shellfish beds may be broken up and scattered about, buries in sediment, or both. Physical changes from hurricanes also include the opening of new passages or the closing of old ones, which can alter current patterns and intensities. These changes create problems for sessile organisms reliant on large amounts of water being transported over their location for feeding, distribution of larvae, and other natural functions.

Floodwaters are capable of transporting large quantities of sediment and sludge, and at the same time flush pockets of poor-quality water from upstream areas. These floodwaters are ultimately delivered to an estuary where the sediments smother and contaminate the molluscan shellfish in varying degree. In addition, flooding may adversely affect mollusks by exposing them to abnormally large quantities of fresh water for prolonged periods. Long periods of exposure to water of very low salinity cause mollusks to close their shells and stop pumping. Physiological changes such as altered respiration and metabolism occur as a consequence, leading to a weakened condition and an increased susceptibility to disease. As an example, Hurricane Agnes caused heavy mortalities in oysters and soft clams in the upper Chesapeake Bay. A study done for the Baltimore District Corps of Engineers revealed that in Maryland, as a result of Hurricane Agnes, over 90 percent of the soft-shell clams died from the combined stresses of low salinity and high temperature. 17

Harvesting may be stopped in such cases to preserve that portion of the resource that remains viable and thus capable of replenishing the population over a period of time.

Another problem associated with hurricane flooding is contamination of estuarine waters by raw sewage from treatment plants which, as a

I/ "The Effects of Tropical Storm Agnes on Chesapeake Bay," Baltimore District, Army Corps of Engineers, March 1975. 
result of heavy rains, are themselves flooded. This situation usually results in the contaminated shellfish beds being closed for public health reasons.

The effects of floods of less than hurricane-driven proportion are not necessarily negative and can in fact have beneficial results. Periodic freshets delivered to an estuary are beneficial to mollusks of commercial value. These minifloods serve to lower the salinity and purge the shellfish beds of some of the many predators found therein, which may be intolerant of very low salinities. Examples are conchs and oyster drills that prey on oysters in brackish waters of higher salinities.

Winds of less than hurricane speeds can cause direct physical damage to shellfish beds. Moreover, high winds cause turbulence, mixing the bottom waters and suspending sediments and associated contaminants. Recombinant materials eventually resettle and may cause varying degrees of smothering or contamination, or both, among the molluscan population.

In shallow estuaries, wind-driven high and low tides may expose or flood shellfish flats and reefs for extended periods of time. As a protective device some shellfish, particularly oysters, remain dormant during adverse conditions. During this time there is to pumping activity and therefore no food or oxygen is taken in. These tides may alter the normal fluctuations in flow patterns of an estuary--i.e., the fluctuations may bring about minifreshets or an extended period of higher than normal salinities. These fluctuations influence the distribution of predators and the feeding patterns as mentioned above, but again the degree of influence varies with wind intensity.

Hurricanes, floods, and high winds also tend to intensify problems along the coast as well as in estuaries. During inclement weather particularly, the risk potential for oil spills due to shipping accidents and damage to coastal structures is increased. Section III-B-4, Coastal Zone Development, treats this subject in greater detail.

Threats to the shellfish environment resulting from natural phenomena are intensified by man's activities. The potential degradation of the molluscan shellfish habitat during hurricanes, floods, and strong winds, is increased due to the added effect of coastal development, resulting mainly from energy resource development, population influx, and demands for recreation. The trend in increased damages is a function of increased development rather than an increase in the occurrence of natural phenomena. The water quality in upstream waters of estuarine tributaries is progressive1y becoming degraded due to competing uses of the stream by industrial and urban development. Projects for the construction of locks and dams for flood plain protection of these developments further degrade water quality. 


\section{Uncontrolled Runoff}

Runoff is a term applied to that part of the hydrologic cycle in which water flows diffusely over ground surfaces on its way to a collecting stream and on to the "ultimate sink"--the ocean. From there water evaporates and reforms into clouds, from where rain falls to become runoff once again. Runoff results from rain, sleet, hail, and snow, and varies with season, with climate, and with soil type.

Principal runoff contaminants result from imprudent agricultural, forest, and urban activities. Plowing and clearing releases sediments, fertilization releases nutrients, plant and animal pest control releases pesticides, and livestock wastes result in the release of oxygen-demanding wastes and large quantities of micro-organisms.

Forest activities that release sediments include clear-cutting of timber, construction and use of logging roads, the drainage of bogs and swamps, and delayed replanting of overcut areas. Urban activities culminating in the construction of buildings and roads generate large quantities of sediment. Industrial activities utilize stationary machinery and transportation vehicles which contribute oils, greases, and heavy metals.

The spraying and fertilizing of lawns, gardens, and agricultural crops release pesticides and nutrients. In urban areas the runoff problem is intensified because of buildings and extensive paved surfaces. Such land modifications result in the rapid transporting of large volumes of water heavy in solids, nutrients, oxygen-demanding waste, heavy metals, pesticides and animal and human wastes contaminated by viruses and bacteria to sewers or directly to receiving waters.

Table 1 represents a perspective on the quantity and types of wastes in urban storm runoff. 
Table 1.--CALCULATED QUANTITIES OF POLLUTANTS THAT WOULD ENTER RECEIVING WATERS--HYPOTHETICAL CITY

$\begin{array}{cll}\begin{array}{c}\text { Street Surface } \\ \text { Runoff }\end{array} & \text { Raw } & \text { Secondary } \\ \text { Following 1-hr } & \text { Sanitary } & \text { Plant } \\ \text { Storm } & \text { Sewage } & \text { Effluent }\end{array}$

Settleable p.lus suspended solids $(1 \mathrm{~b} / \mathrm{hr})$ 560,000
5,600
880 1,300 130

BOD5 $(1 \mathrm{~b} / \mathrm{hr})$ 1,100 110

Kjeldah1 nitrogen (1b/hr) 880 210 20

Phosphates ( $1 \mathrm{~b} / \mathrm{hr}$ ) 440 50 2.5

Total coliform bacteria (organisms/hr) $4000 \times 10^{10}$ $460,000 \times 10^{10}$ $4.6 \times 10^{10}$

Source: Sartor and Boyd (1972) in "Chesapeake Bay Future Conditions Report," Appendix 12, "Fish and Wildlife," draft, U.S. Fish and Wildlife Service, Department of the Interior, 1976.

Suspended and settleable solids, oxygen-demanding wastes, nutrients, heavy metals, and pesticides constitute the five major discharge constituents of stormwater runoff. A major impact of suspended sediments is their ability to transport metals, halogenated hydrocarbons, microbes, and nutrients adsorbed and absorbed to the particle surface. Another significant impact of sediment is the increase of turbidity which decreases light penetration necessary for photosynthesis and therefore production of plankton, a prime food source for molluscan shellfish. Sediments transported to an estuary may also, in the course of time, bury large areas of shellfish beds. For example, over a 36-year period, 6,000 to 7,000 acres of productive oyster reefs were smothered in Matagorda Bay, Texas.시 The transport of sediments to estuaries also requires routine maintenance dredging of channels and canals for navigation--a significant problem to molluscan shellfish. This problem is discussed in Section III-B-4, Coastal Zone Development.

1/ Norris, 1953, in Galtsoff, P.S., "The American Oyster, Crassostrea virginca," Fishery Bulletin, Vol. 64, 1964. 
Nutrients, namely nitrogen, phosphorus, and oxygen-demanding organic materials, present significant problems for molluscan shellfish in a variety of ways. Excessive nutrient enrichment of waters tends to create large blooms in plankton, particularly algae, a food supply of shellfish. The consequences of this phenomenon for molluscan shellfish are not entirely understood, but there appear to be three principal effects. Excessive numbers of unicellular algae may choke the filter feeding mechanisms. Shifts in species composition may starve mollusks whose diet is species--specific. Further, the microbial decomposition, or nocturnal respiration of large numbers of short-lived organisms uses proportionately large amounts of oxygen also needed by the shellfish. Finally, high numbers of undesirable species of algae can cause objectionable flavor in mollusks or may result in a concentration of bio-toxins unacceptable for human consumption. Further descriptions of these effects are found in the case studies of Great South Bay, New York and Raritan Bay, New Jersey, presented in Appendix A. In the Chesapeake Bay area, near cities such as Baltimore, Washington, Norfolk, and Richmond, dissolved oxygen levels are often already depressed because of waste discharges. Surges of oxygen-demanding substances from stormwater discharges can cause dissolved oxygen (DO) to drop to levels that result in severe stress and mortality among estuarine organisms such as shellfish.

Pesticides are transported to the estuary in solution or adhered to particles where the pesticides are then deposited in sediment or taken up by organisms. The uptake may occur directly through ingestion and absorption, or indirectly through the food chain. Very little is known about their physical and chemical behavior in living organisms. Not enough is known about these compounds to allow accurate prediction of their effects, however, enough is known to cause concern. Studies in Georgia have shown Toxaphene levels in one case to be 6 parts per million (ppm) in oysters living two miles from a Toxaphene plant outfall, and in another case dredging activity caused Toxaphene levels in oysters to vary between 2 and $5 \mathrm{ppm}$. Toxaphene, along with DDT and Parathion, is toxic to oysters at concentrations of approximately one ppm in water.I/ Mirex, a highly persistent pesticide shown to be moderately carcinogenic in laboratory studies and chronically toxic to crabs and shrimp was found nationally to be the fourth most commonly found pesticide residue among oysters and other shellfish. 1 )

Some bacteria and viruses from animal wastes are known to be harmful to man as well as to livestock and other animals. However, there is a lack of adequate information particularly concerning specific types of bacteria and viruses and their concentration in runoff. In urban storm runoff, large quantities of bacteria accompany large volumes of water. If this water is not released by storm sewers directly to the receiving waters, it can be stored for short periods of time, recirculated for primary and secondary treatment, and then released. However, due to increased construction costs

If Ming-Yu Li, "Pollution in Nation's Estuaries Originating from the Agricultural Use of Pesticides," in "Estuarine Pollution Control: A National Assessment," report in preparation, U.S. Environmental Protection Agency, 1976. 
and the larger land requirements, this method is rarely used. In the case of combined storm and sanitary sewers the added storm runoff flow to the treatment plant tends to flood the system, causing treatment to become ineffective. Often the best that can be done is to disinfect the effluent in an effort to decrease the potential risk of releasing waters with large amounts of microorganisms of basically unknown character and concentration. In treating urban runoff via separate or combined sewers, large doses of chlorine are administered for disinfection. Aside from the doubtful effectiveness of chlorine as a disinfectant, particularly for viruses, there is question of its effect on the environment as a toxic substance. This problem is further addressed in the discussion of municipal waste treatment in Section III-B-3, municipal activities.

Of all the waste sources, the most difficult to control are those not emanating from end-of-the pipe or other discrete points. Contaminants carried in runoff are one of the most significant of these uncontrollable wastes. Voluntary sources control practices in logging, plowing, and construction are sporadic and have questionable effectiveness. A large part of the problem is the lack of control technology. The solution in some cases may be a combination of structural and nonstructural methods. Examples of the former may include walls, dikes, ditches, and barriers. Examples of the latter include permits, ordinances, and comprehensive planning.

\section{Diseases and Predation}

Most of the adult molluscan shellfish of commercial importance are sessile organisms; they are mobile only in the free-swimming larval stage of their life cycle, a comparatively short period. This means that when environmental conditions become adverse, the mollusk cannot move to a more suitable habitat, but must remain and endure the consequences. This vulnerability is partially compensated for by having a durable shell, which in some species may be closed for short periods of adverse conditions.

Diseases of bacterial, viral, and fungal origin, and parasites, commensals, and predators of many kinds affect molluscan shellfish in various ways. Oysters, clams, and mussels may suffer from both infection and infectious diseases. The first category is associated with the malfunction of physiological systems, a typical proliferative diseases, and deficiencies in the environment such as lack of food, unsuitable salinity and water temperature, and pollution by domestic sewage and industrial wastes. The second category, infectious diseases, is caused by pathogens and parasites. Clear distinction between the two types of pathological conditions is not always possible because resistance to infection is lowered by an unfavorable environment, and a shellfish weakened by adverse conditions more easily succumbs to infection. Heated water inflows tend to decrease activity in shellfish, causing them to be more susceptible to viral infection. Changes in freshwater inflows may affect the distribution of salinity dependent disease organisms, such as MSX (Minchinia nelsoni), M. costalis and Dermocystidium marinum. Pesticides and hydrocarbons have been shown to be associated with various disorders and the strong possibility exists that molluscan collagen-vascular 
aberrations occur as a"result of Kepone contamination. 1/ Epidemic neoplastic diseases are suspected of being associated with environmental carcinogens. The etiology of noninfectious diseases in mollusks is not very well known. A few microorganisms infecting the mollusks have been identified as pathogens. The taxonomic position of others is not known and some are called by code numbers. Molluscan populations throughout the world suffer from periodic widespread mortalities which are probably associated with infectious agents, but since the life cycles of some of the pathogens have not been described, the evidence remains circumstantial. Two examples of pathogens are discussed below. They were chosen because of their wide occurrence.

The Dermocystidium fungus infecting oysters is probably the most dangerous pathogen associated with periodic mortalities of oysters in the waters of southern states. The major effect of the infection is a loss of weight; an average of roughly 33 percent. The infection produces a mortality which, according to Mackin (1961) and Galtsoff (1964), 2/ have virtually destroyed large populations of seed oysters planted in Louisiana in a single summer. The life history and biology of Dermocystidium have been elucidated, particularly the transport of spores by water and their penetration into the tissues, the details of the reproductive cycle, and the relationship between environmental conditions and the degree of infection.

The microorganism MSX was first discovered when a massive mortality occurred in April and May of 1957, affecting up to 85 percent of the planted oysters in Delaware Bay within three years and almost completely ruining the industry of the States of New Jersey and Delaware. MSX has infective stages in June. The disease can be diagnosed in oysters by August with resulting mortalities in September and subsequent high levels of mortality occurring the following winter and spring. Neither the parasite's life history nor the way in which it infects the oysters is fully understood.

There are many organisms that prey on bivalve shellfish, including flatworms, other mollusks such as oyster drills, starfish, crustaceans,, fishes, birds, and mammals. The most widely distributed species of oyster drill, Urosalpinx, is found along the Pacific and entire Atlantic coasts, and another, Thais, is found on the Pacific, the Gulf of Mexico, and part of the Atlantic coasts. The migration of these drills is rather limited. The egg cases of Urosalpinx may be introduced into beds during seeding. Oyster planting by shellfish growers may be the major factor in the wide dispersal of drills and in its introduction into areas previously free of the predator. They drill holes in the shell by combined physical and chemical action and are particularly destructive to young bivalves. In

1/ Murchelano, R., personal communication, Oxford Marine Laboratory, National Marine Fisheries Service, 1977.

2/ Galtsoff, P.S., "The American Oyster, Crassotrea virginica," Fishery Bulletin, Vol. 64, 1964.

3/ Currently green crabs have begun wreaking havoc among the soft shell clams along the Maine coast. Robert Dow, Maine Department Marine Resources, personal communication, November, 1976. 
Cape Cod coastal waters, which are infested by these snails, the oyster spat (young) have very little chance of surviving the first year. Seed oysters are often wiped out before the end of the second year. Adults with thick shells suffer less. There are many places in Long Island Sound, on the eastern shore of Virginia between Chincoteague and Cape Charles, and in other regions, where drills commonly kill 60 to 70 percent of the seed oysters and sometimes annihilate the entire crop. Brackish water bars the drills from the upper parts of estuaries. Survival of drills in water of low salinity depends on the temperature and on the concentration of salts to which they were acclimated. As discussed in Section III-A-1, Hurricanes, Floods, and Strong Winds, floods tend to purge shellfish beds of many predators, drills included.

One species of starfish on the Atlantic coast, Asterias, is quite destructive. Accurate statistics on the destruction caused by this species are not available. However, the numerical strength of a starfish population over a relatively small area can be visualized from the record of only one company which in 1929 removed over 10 million adult starfish from 11,000 acres of oyster beds in Narragansett Bay.1/ Generally, starfish populations on various parts of the Atlantic coast fluctuate within wide limits with years of great abundance often followed by years of relative scarcity. The reproduction season of starfish in New England slightly precedes that of oysters. When oyster larvae reach the shelling stage, the substrate space available for their attachment is already occupied by young starfish. The new set of oysters may be completely decimated by young starfish. Adult starfish are passively transported by currents floating just above the bottom. They feed on mollusks by mechanically forcing the shell open far enough to evert their stomachs and digest the body without first ingesting it. Starfish are usually found in water of high salinity and do not invade shellfish beds in brackish water. Control methods usually include mopping or dredging.

Environmental contaminants which may only subtly affect shellfish populations can produce a food product which is unsafe for human consumption. For example, mollusks can concentrate human pathogens such as typhoid, polio, hepatitis and other microbial agents. However, there have been no known cases of transmittal of polio viruses to humans through consumption of mollusks. Noninfectious agents such as paralytic shellfish poisoning (PSP), Kepone, heavy metals and other industrial and agricultural contaminants are also concentrated by mollusks which can limit their marketability. Thus, these factors affect the molluscan shellfish industry significantly.

\section{Red Tides and Other Plankton Blooms}

The food requirements of various molluscan species are not clearly understood, nor is there a clear understanding of the water quality requirements of the unicellular algae on which they feed. It is

1/ Galtsoff, P.S., "The American Oyster, Crassostrea virginica," Fishery Bulletin, Vo1. 64, 1964. 
difficult to fully explain the mechanisms involved in the cause, and therefore the control, of plankton blooms.

The high concentrations of phytoplankton that occur during blooms can be harmful to shellfish. Experimental work has clearly shown that at a certain high concentration of several forms (Nitzschia closterium, Prorocentrum triangulatum, Englena viridis, and Chlorella), the rate of water transport by mollusks is reduced, and feeding ceases. 1/

A recent plankton bloom off the New Jersey coast that resulted in the death of a large number of finfish and surf clams was discussed during the study interviews. An investigation had been made and a report submitted by the National Marine Fisheries Service. $2 /$ It was suspected that the cause for the algal bloom was the presence of abundant nutrients from the New York Bight, New Jersey shore communities, and discharges into Raritan Bay and New York Harbor. The low oxygen levels responsible for the fish kills were probably a result of oxygen demand by microbes in decomposing the algal cells. Further details are given in Appendix A in the case study on Raritan Bay, New Jersey.

A major difficulty with large algal blooms is the increased production of metabolities, some of which are toxic to fish and humans. One of these toxins causes paralysis and even death in humans. The disease is known as paralytic shellfish poisoning (PSP). The toxin apparently has no adverse effect on shellfish, but a reliable antidote is not known for persons affected by poisoning. Toxins are present in three or four species of plankton (Gonyaulax) that are ingested and metabolically assimilated by shellfish. The problem is often repeated and unpredictable and is an important factor in consumption of shellfish species on the North Atlantic and Pacific coasts. The shellfish involved on the East Coast are primarily mussels and clams. In Maine, this has recently become a serious and recurring problem; the presence of these species of plankton during the summer is cause for closing shellfish beds until the threat of contamination has passed. However, additional information is being sought on the cause and effect relationships involved. $3 /$ PSP toxin has also been frequent problem on the Pacific coast. California issues a coast-wide closure order for mussel and clam beds from May 1 to October 31. Some bays have been closed due to toxicities in mussels. 4 /

1/ Loosanoff and Engle, 1947, in Galtsoff, P.S., "The American Oyster, Crassostrea virginica," Fishery Bulletin, Vol. 64, 1964.

2/ "Mortalities of Fish and Shellfish with Anoxic Bottom Water in the Middle Atlantic Bight," U.S. Department of Commerce, National Marine Fisheries Service, September 1976.

3/ Dow, R.L., personal communication, December 1976.

4/ "A Comprehensive Review of the Commercial Mussel Industries in the United States," (draft), Appendix III of "Report of the Secretary of Commerce to Congress, Section 16--Shellfish Sanitation Regulation--CZM Act Amendments," p. 9.5b-3, Office of Fisheries Development, National Marine Fisheries Service, 1977. 
Another algal organism that blooms under appropriate stimuli is the dinoflagellate, Gymnodium breve, occurring frequently on the Gulf coast of Florida. The plankter is a rusty red and imparts a distinct color to the water when appearing in great quantity, hence the term "red tide." This red tide has caused several enormous fish kills. The toxins of this organism have also been found in mollusks. There is concern about possible deaths in humans as a result of ingesting mollusks which have concentrated these toxins. Red tides have occurred in many areas.

Control of toxic algal blooms may or may not be possible through an understanding of the organisms role in estuarine and marine ecosystems. As a starting point, attempts to control nutrients from runoff as well as from domestic waste (sludge dumping, ocean outfalls, and septic systems) may have a beneficial effect. As long as these activities and practices continue and as long as there is a human population influx into coastal zones, the natural phenomena of red tides and other plankton blooms may occur with greater frequence and intensity.

\section{B. Effects of Man's Activities}

\section{Agricultural and Silvicultural Activity}

Between 1950 and 1974, agricultural production per acre increased over 50 percent. The Nation's population increased by about 40 percent and the average amount of food consumed by each person increased 8 percent while agricultural product exports almost doubled. Although land in production decreased by 4 percent during this period, greater use of pesticides, fertilizers, irrigation, improved farm management, better crop varieties, and intensive use of productive lands increased the harvest. 1 f

Sediment, nutrients, microorganisms, and pesticides are the principal sources of concern resulting from agricultural and silvicultural activities Runoff is the chief means by which these constituents reach the estuaries and ultimately molluscan shellfish. Sediments and nutrients and their origin and impact on molluscan shellfish were previously discussed in Sections III-A-2, Uncontrolled Runoff, and III-A-4, Red Tides and Other P1ankton Blooms.

\section{a. Disease Organisms}

Bacterial diseases that have been transmitted to human beings or livestock by contaminated water include not only intestinal illnesses such as dysentery, typhoid fever, paratyphoid fevers, cholera, and gastroenterities, but also less frequently, tuberculosis, anthrax, and others. Since pathogenic diseases, such as brucellosis, tularemia, and salmonella infections are common to man and certain animal species, it

1/ Carter, H.L., "Future Land Requirements to Produce Food for an Expanding Population, Perspectives on Prime Lands," U.S. Department of Agriculture, 1975. 
is highly probable that these diseases are transmitted in water polluted by animal discharges.1/ The survival of disease organisms in the environment depends on such factors as oxygen supply, pH, temperatures, sunlight, nutrient supply, sedimentation, etc. Other factors determining pathogenic infection include virulence, chance of ingestion by proper hosts, and the resistance of the hosts.

Because of the operation of so many variables, public health practice is based not on the probability but on the possibility of infection. Public health officials are concerned with ensuring that shellfish are consumed without harm to the public. Of course, it is possible for water to be so safe that absolutely no risk is taken when using it; however, it is possible to ensure that water is safe to such a degree that the dangers involved are small' enough to be properly ignored. As stated earlier in the report, molluscan shellfish pump large quantities of water. To emphasize this point, the following example is given. Under optimal conditions of temperature and salinity, an average adult oyster can transport water at the rate of 15 liters per hour. With 250 large oysters to a bushel and 1000 bushels per acre, an oyster bed of that size would require 3.75 million liters of water per hour. 2/ Accordingly, most constituents in shellfish growing waters pass through the gills of the shellfish with the consequent risk of retaining disease organisms.

The difficulties of controlling unsanitary wastes from agricultural operations basically stem from two major problems. The first is that except for cattle feedlots and irrigation reuse return flow, there are no EPA requirements for treating contaminants from agricultural activities. The consequences of this are brought out in the case study of Apalachicola, Florida, presented in Appendix A.

The second problem became apparent to the study team during discussions with many state officials dealing in health, water quality, and the shellfish resources. There was not only a general disagreement concerning the suitability of current bacterial standards for shellfish growing waters, but there was also a lack of understanding concerning the source and quantity of microbial contaminants from livestock, as well as the degree of threat to human health. This point was emphasized by a complaint from one state official who said there was no quick way to distinguish between coliforms from humans and coliforms from cattle. This complaint is partly due to lack of information on the etiology of viral and bacterial organisms involved and partly. to the inability of state-of-the-art analytical methods to provide quick, accurate answers.

1/ Snyder, C.W., 1951, and S.C. Prescott, C.E.A. Winslow, and M.H. McCrady, 1945, in J.E. McKee and H.W. Wolf, "Water Quality Criteria," U.S. Department of Health, Education and Welfare, Public Health Service, 1963.

2/ Galtsoff, P.L., "The American Oyster, Crassostrea virginica," Fishery Bulletin, Vol. 64, 1964. 
The extensive use of chemical pesticides poses a threat to the molluscan shellfish industry. The most important aspect is the threat to the resource itself from chronic exposure to sublethal levels of toxic substances. Sublethal effects of contaminants are manifestations of physiological, functional or biochemical changes that do not directly kill, but impair the ability to survive. Studies of the effects of a number of pollutants, particularly pesticides and heavy metals, have been performed on embryos and larvae of the American oyster, Crassostrea virginica, and the hard clam, Mercenaria mercenaria. In most cases embryos of these two bivalves were more sensitive to these pollutants than larvae. It is also known that the embryonic and larval stages of marine animals are generally more sensitive than the juvenile and adult stages. Studies of the effects of heavy metals on oyster embryos have also shown that in some cases genetic damage occurs at concentrations which do not cause mortality. This implies that, although the embryos were not killed outright, they might not survive through their larval stage, thereby affecting recruitment. A distinction is made between developing embryos and fully formed larvae because of the differences in sensitivity between the two stages. Moreover, growth of larvae may be drastically reduced at concentrations of a pollutant too low to cause direct mortality. Such a reduction in growth would prolong the pelagic life of the larvae and thus, increase their chance of loss through predation, disease and dispersion, therefore reducing recruitment into the population. $1 / \underline{2}$ / $\underline{3} / \underline{4} \underline{5} / \underline{6} /$

1/ Calabrese, A. and D.A. Nelson. Inhibition of embryonic development of the hard clam, Mercenaria mercenaria, by heavy metals. Bull. Env. Contamination and Tox. Vol. II(1), 1974.

2/ Davis, H.C. and H. Hidu. Effects of pesticides on embryonic development of clams and oysters and on survival and growth of the larvae. Fish. Bull. Vol. 67(2), 1969.

3/. Calabrese, A. How some pollutants affect embryos and larvae of American oyster and hard-shell clam. Mar. Fish. Rev. Vol. 34(11-12), 1972.

4/ Calabrese, A. and H.C. Davis. Effects of "soft" detergents on embryos and larvae of the American oyster (Crassostrea virginica). Proc. Nat. Shellfish Assoc. Vol. 57, 1967.

5/ Calabrese, A., R.S. Collier, D.A. Nelson and J.R. MacInnes. The toxicity of heavy metals to embryos of the American oyster Crassostrea virginica. Mar. Biol. Vo1. 18, 1973.

6/ Calabrese, A., J.R. MacInnes, D.A. Nelson and J.E. Miller. Survival and growth of bivalve larvae under heavy-metal stress. Mar. Biol. 1976. 
Reduction in growth rate, as well as diminished reproductive capabilities, are important because they affect future yields. Lowered disease resistance will also affect production. Some pesticides are enyzme specific and affect non-target organisms such as clams, oysters, and mussels. Mollusks have the ability to concentrate certain pesticides from almost undetectable levels in the environment to levels in their tissues which are unacceptable for human consumption. Kepone concentration in oysters from the lowest James River in Virginja is a good example of concentrations that could be harmful to consumers. In this particular case, the risk is reduced because most of the oysters produced in the lower James River are seed oysters which will be transplanted to Kepone-free growing areas for depuration.

Another aspect of the threat of pesticides to the shellfish industry is that of seizure for violative residues. While this happens only on rare occasions, it is a disaster to the producer whose product is removed from the marketplace. Seafood producers do not have the protection of legislation which would reimburse them for losses due to unintended residues.

There are no tolerance levels for pesticide residues in seafood products since these levels are based only on the intentional application of a chemical to a food product. The Food and Drug Administration and later the Environmental Protection Agency established Action Levels for pesticide residues in seafood for consumer protection. To date, Action Levels apply only to persistent chlorinated synthetics, (e.g., DDT, Dieldrin, Kepone) and to metals.

A parallel action by the Environmental Protection Agency, which may ultimately benefit the shellfish industry, is the gradual elimination of persistent chlorinated compounds and certain other high-rish chemicals. This action should ultimately reduce the threat of pesticides to the seafood industry.

\section{Industrial Activity}

An ever-increasing number of industrial toxicants are appearing in the Nation's waterways. In interviews with Federal and state agency personnel on the East Coast, issues were raised concerning industrial water quality problems affecting estuarine ecology, including the viability of molluscan shellfish resources and sanitary conditions of shellfish growing waters. The problems can be divided into (1) pesticide and chemical manufacturing, (2) industrial waste processing and discharges, and (3) power generation. Table 2 shows the number of discharge permits issued to industries by group. Their relative distribution indicates the activity of a given group of industrial dischargers. Discussion is limited to the remaining four specific categories; chemical and allied products, paper and allied products, electric and gas utilities, and petroleum and coal products. 
Groups
Number of Discharge

Permits
Chemical and allied products

522

Paper and allied products

407

Electric and gas utilities

392

Textiles

151

Fabricated metal products

149

Iron and steel

142

Petroleum and coal products

136

A11 others

902

Source: Biggs, R.B., "The Effects of Industrialization on the Estuary," in "Estuarine Pollution Control: A National Assessment," report in preparation, U.S. Environmenta1 Protection Agency, 1976.

\section{a. Pesticide and Chemical Manufacturing}

The production of synthetic organic pesticides (fungicides, herbicides, insecticides, and rodenticides) varied between 1.1 and 1.3 billion pounds between 1967 and 1972. If Polychlorinated biphenyls (PCB) production peaked in 1970 at approximately 85 million pounds, decreased by more than half in 1971, and then increased in 1972 and 1973 to approximately 39 million pounds and 42 million pounds, respectively. Oysters were found to accumulate PCBs from the water and PCBs have been shown to significantly decrease oyster growth at levels as low as 5 parts per bililion (ppb). Il

Table 3 indicates the production of acids in the United States from 1960 to 1973, and in virtually all cases it has increased.

1/ Lincor, J.L., "The Impact of Synthetic Organic Compounds on Estuarine Systems," in "Estuarine Pollution Control: A National Assessment," report in preparation, U.S. Environmental Protection Agency, 1976. 
Table 3--ACID PRODUCTION, BY KIND--1960 to 1973

(Billions of Pounds, Approx.)

Year:

1960

1965

1970

1972

1973

Acids

$\begin{array}{lccccc}\text { Sulfuric } & 36.0 & 50.0 & 60.0 & 62.0 & 64.0 \\ \text { Nitric } & 6.6 & 9.8 & 13.4 & 16.0 & 16.8 \\ \text { Phosphoric } & 4.2 & 7.8 & 11.4 & 13.4 & 13.6 \\ \text { Hydrochloric } & 2.0 & 2.8 & 4.0 & 4.6 & 5.0 \\ \text { Hydrofluoric } & 0.2 & 0.3 & 0.4 & 0.4 & 0.5 \\ \text { TOTAL ACIDS } & 49.0 & 70.7 & 89.2 & 96.4 & 99.9\end{array}$

Source: "Statistical Abstract of the United States," Bureau of the Census, Department of Commerce, 1975.

Chemical wastes enter estuarine and marine systems by stream and river flow and by ocean dumping. Their toxic properties and ecological effects have only recently received widespread attention. Concern regarding the actual and potential effects of these chemicals upon fishery resources was expressed by agency respresentatives in New York, New Jersey, and in recent publications.

Filter feeding mollusks accumulate metals such as aluminum (found to reach levels of $5 \mathrm{~g} / \mathrm{kg}$ ) from ingestion of phytgplankton, and enormous amounts of zinc $(99 \mathrm{~g} / \mathrm{kg})$ from direct filtering. 1 Davey and Phelps also state that sediments in estuaries tend to have unnaturally high levels of metals, and that benthic systems are frequently stressed beyond the biological breaking point. They also suggest that estuarine waters are not uniformly mixed, and can contain high local concentrations of metals at sediment/water or freshwater/saltwater interfaces. They cite as an example of the human health aspect the outbreak of mercury poisoning in Japan in 1953 from contamination of fish and shellfish.

I/ Davey, E.W. and D.K. Phelps, "Trace Metals in the Oceans: Problem or No?", in "Estuarine Pollution Control: A National Assessment," report in preparation, U.S. Environmental Protection Agency, 1976. 
Solid and semi-solid industrial waste discharges entering fresh and marine waters amount to 235 million tons (dry weight) per year. In addition, an estimated 35 million tons of industrial wastewater sludge are disposed of annually. I/ The disposal of these quantities poses chronic threats to marine and estuarine communities, including shellfish. The dumping of waste into the New York Bight is discussed in the Raritan Bay, New Jersey case study (see Appendix A.)

Pulp waste from paper product companies contains toxic substances, such as sulfites, that adversely affect oyster physiology. High biochemical oxygen demand (BOD) associated with pulp wastes reduces oxygen levels for aquatic organisms, including molluscan shellfish. Moreover, pulp mill wastes have been shown to reduce the number of hours the valves of mollusks are open, generally in proportion to the concentration of toxic substances in the water. $\underline{27}$

Permitted pulp wastes are still a significant problem in the Pacific Northwest. In the State of Washington, for example, there were five companies that discharged approximately 100 million gallons per day (GPD) into receiving waters in the eastern portion of Grays Harbor during 1974.의 Due partially to the extensive shellfish resources in the western portion of the Harbor, efforts have been made to mitigate the impacts of the discharges. (See the case study on Washington State in Appendix A.)

Other industrial discharges, including seafood processors, are located on or near the Nation's estuaries. Using Washington State as an example, approximately three million GPD of seafood processing wastes enter State estuarine areas. Most of these discharges take place in the proximity of other industrial dischargers in Grays Harbor mentioned above. However, the volume is considerably less, and the biodegradable components of these discharges seem to pose a less serious threat to water quality degradation than is the case with industrial effluents.

The number of inadvertent or accident polluting discharges reported in the U.S. waters during 1973 was greater than 13,000 with a total volume of approximately 24.3 million gallons. Tankers were responsible for nearly 4.5 million gallons of discharge while onshore facilities accounted for approximately 5.8 million gallons during that one year. The number of oil spills was close to 3,000, and the volume approximated

1/ "Draft final report to the National Commission on Water Quality," Environmental Quality Systems, Inc., 1976.

2/ Galsoff, P.S., "The American Oyster, Crassostrea virginica," Fishery Bulletin, Vol. 64, 1964.

$3 /$ Washington Marine Atlas, Vol. 4, Department of Natural Resources, State of Washington, 1974. 
13 million gallons. As the number of coastal-based petroleum handling facilities and their production capacity expands, the number and volume of discharges is expected to increase proportionally unless prompt action is taken. A recent estimate for petroleum and hydrocarbons released from coastal refineries into the marine environment of the United States is on the order of 66 million pounds per year. 1 /

The physiological impacts on shellfish organisms begin when the oil fractions enter from the water across membrane surfaces and impede ciliary activities. Oil uptake can sometimes be discharged when shellfish are depurated in clean water. Conversely, three independent studies found that oysters exposed for two months to an oil spill. did not appreciably purge oil pollutants even after 180 days in cleaner waters.1/ A discussion of coastal development, including oil shipping commerce and its impacts, is given in Section III-B-4, Coastal Zone Development.

\section{c. Power Generation}

Utilities are major dischargers of heated effluents into surface waters of the United States. Large modern power plants using once-through cooling such as those located at Hog Island on the James River, Virginia and at Calvert Cliffs, Maryland, heat more than two billion gallons of water per day. $/$ The substantial volume of heated water and the chemical constituents of the wastewater from such plants can be expected to affect biological resources.

Aquatic organisms, including larval stages of shellfish, are often entrained through this cooling system where they are subjected to heat shock, pressure changes, shear forces, biocides and other potential damaging effects before discharge. The condenser cooling systems of these plants are regularly fouled by a large variety of sedentary life forms, thereby restricting water flow and efficiency of the plant. Biocides, such as chlorine compounds, are regularly used to eliminate these undesirable species. Treatment can consist of continuous low level application of biocide to the cooling water flow, or intermittent treatment at either high or low level concentrations. Biocides are generally destructive to organisms entrained at time of treatment as well as to the target forms. Discharge of chlorine and other biocides to receiving waters is a major problem. Section III-B-3-d, chlorination and other Forms of Disinfection, discusses many of the downstream impacts of chlorination which are similar in many respects to the antifouling processes in power plants.

1/ Farrington, J.W., "Oil Pollution in the Coastal Environment," in "Estuarine Pollution Control: A National Assessment," report in preparation, U.S. Environmental Protection Agency, 1976.

2/ "Chesapeake Bay Future Conditions Report," Appendix 12, "Fish and Wildlife," draft report, U.S. Army Corps of Engineers, Baltimore District, January 1976. 
Other methods of controlling the fouling problem and discharges of biocides include mechanical cleaning, heat treatment by reversing the flow, and several types of closed-cycle cooling. The latter means is especially effective in reducing the numbers of fouling organisms, the volume of water taken from the estuary, the amount of biocide needed, and the discharge of both heat and biocides to the estuary. Several other major physical, chemical and biological impacts of power plants to the receiving waters are also eliminated or reduced when a closed-cycle cooling system is used. A closed-cycle system may require withdrawls of only one to three percent of the volume of input water as required for once-through cooling. I/

However, algicides and fungicides are used for cooling-tower cleansing at an annual rate of three million pounds, and wood used in cooling-tower construction is treated with chromated preservatives. 27 Depending on the volume of water, total he st output, temperature rise of cooling water, and other factors, heated effluents may not always appear to be as serious a threat to shellfish as either the use of chlorine as a biocide or the synergistic effects of power plant condenser erosion or corrosion combined with chlorine. In the Chesapeake Bay, 2.2 million pounds of chlorine (see the following section for discussion of breakdown products, toxicity, etc.) per year are discharged from power generation facilities. 3 / Jensen 4 / states that in studies made at the Chalk Point Generating Station on the Patuxent River estuary in Maryland, before and after operation, oyster beds within 1200 feet of the discharge canal showed no major effects on the growth, condition, and reproductive development as a result of plant operation. However, chlorination procedures were said to be responsible for substantial reduction of phytoplankton photosynthetic capacity upon which oysters are

1/ Biggs, R.B., "The Effects of Industrialization on the Estuary," 1.c. "Estuarine Pollution Control: A National Assessment," report in preparation, U.S. Environmental Protection Agency, 1976.

2/ von Rumker, R., E.W. Lawless, and A.F. Meiners, "Protection, Distribution, Use, and Environmental Impact Potential of Selected Pesticides," Office of Pesticide Programs, U.S. Environmenta1 Protection Agency, 1974.

3/ Davis, W.P., and D.P. Middaugh, "A Review of the Impact of Chlorination Processes Upon Marine Ecosystems," in "Estuarine Pollution Control: A National Assessment," report in preparation, U.S. Environmental Protection Agency, 1976.

4/ Jensen, L.D., "The Effects of Thermal Discharges upon Aquatic Organisms in Estuarine Waters with Discussion of Limiting Factors," in "Estuarine Pollution Control: A National Assessment," report in preparation, U.S. Environmental Protection Agency, 1976. 
partially dependent. In another study, Mihursky $1 /$ states that chlorine can kill organisms and oxidize the organic compounds of bottom sediments and thus release absorbed heavy metals. Further, he states that these effects, when combined with heavy metal releases from condenser system corrosion or erosion, can be found in "magnifier-concentrator" organisms such as shellfish (see Section III-B-3, Municipal Activities, for discussion of chlorination).

Kennish $2 /$ recently reported that hard clams at the Oyster Creek Nuclear Power Plant in New Jersey showed reductions of 10 to 30 percent in the rate of shell thickness growth during summer because of high water temperatures resulting from plant operation. Effects were noted up to $1.6 \mathrm{kilometers} \mathrm{from} \mathrm{the} \mathrm{mouth} \mathrm{of} \mathrm{Oyster} \mathrm{Creek.} \mathrm{It} \mathrm{was} \mathrm{also}$ noted that sudden temperature changes (by as much as $5^{\circ} \mathrm{C}$ within several hours time) resulted in physiological shock and reduced growth.

Roosenburg $3 /$ reported increased copper uptake by oysters near the outlet of a steam electric station on the Patuxent River in Maryland. He suggested that copper uptake may be increased by cther stress factors such as heat or biocides. He cited several authors who reported on similar events. He states that copper uptake in oysters results in a green coloration and a bitter taste, rendering them unfit for human consumption and disqualifying such areas for the production of marketable oysters.

Hydroelectric power generation which approached 3000 trillion BTUs in $1974^{4}$ may also affect estuarine waters. The impoundment of water for energy purposes by dams and reservoirs alters the flows into estuarine systems. Potential loss of essential nutrients and changes in estuarine

1/ Mihursky, J.A., "Thermal Discharges and Estuarine Systems," in "Estuarine Pollution Control: A National Assessment," report in preparation, U.S. Environmental Protection Agency, 1976.

2/46/Kennish, Michael J., "Monitoring Thermal Discharges: A Natural Method," Underwater Naturalist, Vol. 9, No. 4, pp. 8-11, June 1976.

3/ Roosenburg, William H., "Greening and Copper Accumulation in the American Oyster, Crassostrea virginica, in the Vicinity of a Steam Electric Generating Station," Chesapeake Science, Vol. 10, No. 344, pp. 241-252, September - December 1969. 
hydrodynamics are but two of the impacts associated with such upstream alterations.1/2/ The impacts of these changes on estuarine and coasta 1 fishery resources, which are totally or highly dependent on estuarine waters for all or some portion of their life cycle, are relatively unknown (see the case study on Apalachicola Bay in Appendix A).

\section{Municipal Activities}

Cities, towns and villages can adversely impact natural resources by construction and maintenance activities, wastewater collection and treatment, and solid waste disposal。 The following discussions relate the significance of these activities to molluscan shellfisheries.

\section{a. Construction and Maintenance Activities}

Construction and maintenance of streets, roads and highways, rea1 estate developments, shopping centers and industrial tracts can generate significant sediment loads. Section III-A-2, Uncontrolled Runoff, describes sediment effects in greater detail, but it is appropriate here to note that annual loads from construction sites in Rhode Island contributed approximately 278 million tons or 25 percent of the total sediment runoff yield in that state. 37 Since Rhode Island's estuaries also support molluscan shellfisheries, it is appropriate to conclude that sediment loads of this magnitude would directly affect them.

\section{b. Storm and Wastewater Collection}

Extensive impermeable surface areas characterizing urban environments not only remove aquifer recharge capabilities, but also greatly magnify freshwater runoff in stormwater collection and distribution systems. In addition to the sediment, oil, heavy metal, pesticides, and fertilizer "surges" following a rainfall, large volumes of water pass directly into the estuary. Clams, mussels, and oysters are naturally adapted to normal fluctuations between fresh and saline conditions, but prolonged discharges of stormwaters in concert with direct runoff and precipitation can physiologically stress these and like organisms beyond their capacities for self maintenance. (See Great South Bay Case Study, Section 2, Appendix A.)

1/ Livingston, R.L., "Resource Management and Estuarine Function with Application to the Apalachicola Drainage System," in "Estuarine Pollution Control: A National Assessment," report in preparation, U.S. Environmenta1 Protection Agency, 1976.

2/ Whitfield, W.K., Jr., and D.S. Beaumariage, "Shellfish Management in Apalachicola Bay--Past, Present, Future," unpublished report.

3/ "National Water Quality Inventory, 1975 Report to Congress," U.S. Environmental Protection Agency, 1975. 
In some municipalities, sanitary wastewater collection systems lack the structural integrity to prevent leakage of their contents into subsurface soils. Another major cause of contamination and subsequent closure of shellfish beds is the mixing of sanitary and stormwater wastes in combined systems. Obviously, repairing and upgrading collecting systems should be a sought after goal. One study 1 estimated that $\$ 235$ billion may be necessary for adequate stormwater control. However, this value includes the entire nation, and the cost of upgrading priority systems in shellfish states should be considerably less. Enforcing street and parking lot cleanup as well as planning retention-filtration systems into new works should measurably decrease short-and long-term impacts.

\section{c. Sewage and Wastewater Treatment}

As noted above, the sanitary condition of shellfish growing waters is usually associated with the effectiveness of adjacent wastewater treatment facilities. Overloads caused by combinations of municipal wastes and heavy runoff into combined sewer collection systems, inadequate design capacity for present and future population growth, lack of training of small plant operators, and present disinfection techniques that are found to be biologically disruptive to aquatic organisms, appear to be common in facilities throughout the regions. Untreated domestic sludge and effluent wastes containing heavy metals, chlorinated hydrocarbons, and other toxic substances affect the shellfish organism itself and pose a public health hazard when contaminated shellfish are consumed. Excessive and unnatural supplies of nutrient levels in septic tank leachates and sewage effluent stimulate algal blooms. As discussed previously, nutrient levels are associated with estuarine eutrophication, oxygen depletion, and have been related to fish kill. 2 /

EPA has reported that in 1976 there węre 20,881 municipal wastewater treatment facilities in the United States. $\underline{3}$ Facilities included: primary, 2,704; upgraded primary, 67; secondary, 17,049; and advanced or tertiary, 1,061.4/ Eighty-four percent of the facilities were of the secondary type

1/ "Needs Survey," reported in "National Water Quality Inventory: 1975 Report to Congress," U.S. Environmental Protection Agency, 1975.

2/ Clark, J., "Status of Estuarine Ecosystems in Relation to Shellfish Resources," in "Estuarine Pollution Control: A National Assessment," report in preparation, U.S. Environmental Protection Agency, 1976.

3i "Municipal Wastewater Treatment Facilities Directory," draft, U.S. Environmental Protection Agency, 1976.

4/ These definitions applied to the period when the data was first collected (1971). Primary = Sedimentation with or without chlorination. Secondary = Sedimentation and conventional biologic processes (e.g., trickling filter, activated sludge) with or without chlorination. Tertiary = Secondary treatment plus additional conventional treatment which will remove additional BOD and/or solids, e.g., terminal lagoon, sand filter. Source: J. Boyd, telephone communication, 1977. Division of Monitoring and Data Support, U.S. Environmental Protection Agency, Washington, D.C. 
with design capacity flows of less than one million GPD. In 1975, 65 percent of the population relied on primary treatment or no treatment at all. Municipal yaste facilities process an estimated 10,000 dry tons of sludge per day. $\underline{1}$

EPA officials indicated to the study team that perhaps 50 percent of all permitted municipalities will meet 1977 point source effluent limitations. However, if the unreliability of data supplied to EPA by municipalities in the South Atlantic-Gulf States is indicative of the Nation, the 50 percent compliance rate for 1977 may be an unattainable objective.

Assuming that 50 percent of the municipalities are either not in compliance or have not received permits, bacteriological problems currently affecting shellfish will continue. The EPA estimated that over $\$ 50$ billion were required to upgrade existing facilities and construct new ones in the 23 Coastal States. 29 The needs associated with the seven key shellfish producing states highlighted in this report approximated $\$ 29$ billion; of which over half were attributed to the needs of New York State.

Some of the significant municipal waste treatment factors affecting shellfish resources and estuarine water quality are either too difficult to control at present from a technical standpoint, or unrealistic in view of the limited construction monies.

The widespread use of the chlorination process is seen as a significant threat and is treated below in Section III-B-3-d, Chlorination and Other Forms of Disinfection.

\section{d. Chlorination and Other Forms of Disinfection $3 /$}

The use of chlorine for disinfection in wastewater treatment facilities in the United States has increased significantly with the addition of new plants and the upgrading of others. Only recently has the efficacy and environmental impact of chlorine, the least expensive disinfectant, been examined seriously.

Large quantities of chlorine, specifically hypochloric acid (HOC1) and associated breakdown compounds, are released through plant effluents into natural ecosystems. Because of chlorine's high toxicity, its use for

1/ Bastian, R.K., "Municipal Sludge Management," EPA Construction Grants Program, U.S. Environmental Protection Agency, April 1976.

2/ "National Water Quality Inventory, 1975, Report to Congress," U.S. Environmental Protection Agency, 1975.

3/ This problem discussion was written with the assistance of Walter Blogoslawski, Northeast Fisheries Center, NMFS, Milford Laboratory, Connecticut. 
bacterial and viral control by nearly every municipality has caused concern to public health officials, estuarine ecologists, and the public $1 /$

Studies show that oysters reduce pumping activity when chlorine concentrations exceed $0.01 \mathrm{ppm}$; at concentrations of $1.0 \mathrm{ppm}$, effective pumping could not be maintained. 27 Chlorine residuals have been known to exceed 2.0 ppm.

One laboratory study $3 /$ found 15 chlorine derivatives in sewage effluents. Concentrations were nontoxic, but some of the chlorinated organics had a very slow decay process. A buildup of these derivatives in the water column or in the sediments might destroy phytoplanktonic organisms fed upon by shellfish.

In Maryland, 27 million pounds of chlorine per year are discharged into the Chesapeake Bay from municipal wastewater treatment facilities. $4 /$ Twenty-three other states bordering on marine ecosystems similarly employ full-time chlorination.

Recent investigations demonstrated that chlorinated sewage effluents in Maryland and Virginia drastically reduced the total number of fish species downstream from treatment plants. 5 Aquatic organisms normally characterizing streams receiving unchlorinated discharges were not found. A 50 percent reduction in the species diversity index occurred at $0.1 \mathrm{ppm}$. Because estuarine ecology is influenced by upstream events, organisms dependent on organic detritus and other nutrients affected by chlorine residuals would be directly affected.

Residual chlorine or its derivatives from sewage treatment plants caused a massive fish kill in the James River, Virginia, during May and June 1973. - In a laboratory study, mussels detached from their substrate after chlorine levels exceeded $0.02 \mathrm{ppm}$. 7/ Chlorine reacts with humic substances in wastewater to form trihalomethanes, human carcinogens. The chronic exposure of marine animals to trihalomethanes produces an increase in tissue disorders.

I/ $3 / 4 /$ 7/ Davis, W.P. and D.P. Middaugh, "A Review of the Impact of Chlorination Processes upon Marine Ecosystems," in "Estuarine Pollution Control: A National Assessment," report in preparation, U.S. Environmental Protection Agency, 1976.

2/ $5 /$ "Quality Criteria for Water," Office of Water Hazardous Materials, U.S. Environmental Protection Agency, 1976.

6/ Kelly, C.B., "The Toxicity of Chlorinated Waste Effluents to Fish and Considerations of Alternative Processes for the Disinfection of Waste Effluents," Virginia State Water Control Board, 1974.

8/ Conference on Aquatic Pollutants with Special Emphasis on Neoplasia, New York Academy of Science, 1976. 
Concern with fish and shellfish toxicity thresholds is sometimes irrelevant because of other factors. For example, interviews with various Federal agency representatives and a brief review of one treatment plant's monthly records revealed that technical competence was deficient. Overchlorination, periods of underchlorination, or no chlorination and arbitrary chlorination were serious problems. If a plant operator does not consider possible adverse effects of chlorine and its derivatives on the organisms within and downstream of receiving waters, controls, standards, criteria and technologies would be ineffective.

The 1972 Federal Water Pollution Control Act Amendments administered by the Environmental Protection Agency established standards of "best practicable treatment" (BPT) of effluents by July 1977, and "best available treatment" (BAT) by 1983. By 1985 there are to be no discharges into navigable waters. As compliance deadlines approach, with the 1983 goal of "fishable" and "swimmable" waters (emphasis added), and with the goal of "no discharges" by 1985, alternative methods of disinfection may become necessary.

Recently circulated EPA criteria for marine organisms provide a total residual chlorine criterion of $0.01 \mathrm{ppm}$ to afford protection to marine aquatic life. 17 The criteria should also be effective in controlling contaminated wastewater effluents.

However, chlorine reacts quite differently in seawater than in fresh water. Mangum and McIlhenny (1975) $2 /$ found that chlorinated seawater produced a relatively long-lived oxidant believed to be hypobromite. Recent work by Morris and Carpenter $3 / 4 /$ presented at the First Chlorination Conference in October 1975 at Oak Ridge, Tennessee suggested that chlorine reacts with naturally occurring bromide in salt water to form $\mathrm{HOBr}$ which may have profound and/or adverse effects on marine species. Davis and Middaugh5/ suggested actual limits of chlorine or "oxidant species" which will produce lethal effects in various marine organisms.

1/ "Quality Criteria for Water," Office of Water Hazardous Materials, U.S. Environmental Protection Agency, 1976.

2/ Mangum, D.C. and W.F. McIlhenny, "Control of Marine Fouling in Intake Systems--A Companion of Ozone and Chlorine," in Blogoslawski and Rice (eds.), International Ozone Institute, 1975.

3/ Morris, J.C., "The Chemistry of Aqueous Chlorine in Relation to Water Chlorination," pp. 27-42, in Proceedings of the Conference on the Environmental Impact of Water Chlorination, R.L. Jolley, ed., U.S. Envi ronmental Protection Agency, 1976.

4/ Carpenter, J. H. and D. L. Macalady, "Chemistry of Halogens in seawater," in Proceedings of the Conference on the Environmental Impact of Water Chlorination, R.L. Jolley, ed., U.S. Environmental Protection Agency, 1976.

5/ Davis, W.P and D.P. Middaugh, "A Review of the Impact of Chlorination Processes upon Marine Ecosysteme," in "Estuarine Pollution Control: A National Assessment," report in preparation, U.S. Environmental Protection Agency, 1976. 
Dechlorination is said to account for an additional two percent of the total treatment cost associated with disinfection. By first chlorinating the effluent, then dechlorinating to remove potentially harmful substances, residual levels should drop to an acceptable limit. Costs may increase somewhat, but maintenance or enhancement of estuarine resources may make it a worthwhile undertaking.

Ultraviolet (UV) irradiation is also effective for bacterial disinfection. and leaves no residue that could be discharged into receiving waters. It is more expensive than dechlorination however, and the equipment available would limit applicability to plants handling flows of no more than $10 \mathrm{MGD}$. In the intial stages of facility design this process also requires a higher financial outlay than chlorination-dechlorination system.

Ozone is an effective disinfectant with few residuals. Tests in the following locations have all demonstrated the feasibility of ozone disinfection: Whiting, Indiana; Strasbourg, Pennsylvania; Estes Park, Colorado; Los Angeles, California; and Louisville, Kentucky. The Midlands, Michigan sewage treatment plant has treated 6.5 MGD since 1963. In Canada, 20 smaller facilities are in operation. Ozone gas has been used for many years in France and Germany to treat drinking water and wastewater, and today more than 500 municipalities in 50 countries use ozone as a disinfectant. Ozonation, however, is more expensive than either chlorination or ultraviolet treatment.

\section{e. Solid Waste Disposal}

Estuarine areas have historically been convenient disposal sites for municipal and industrial solid wastes. Municipal operations account for 90 percent of the total landfill in the United States.1/

A danger to estuarine waters and organisms is associated with leachates carried in water percolating through the solid waste. Leachate generation in the United States may approach some 46 billion gallons annually, a significant percentage of which enters estuarine areas where it introduces toxicants, heavy metals, pesticides, and oxygen demanding compounds. I/

\section{Coastal Zone Development}

The combination of abundant water supply and proximity to port facilities has prompted manufacturing, refining, and power production industries to make increasing use of the coastal zone (see Section III-B-2, Industrial Activity). During 1975, 447 new plants or plant expansions on or near navigable waters were announced by various companies--a substantial increase over $1974 . \underline{2}$

1/ Feibusch, H.A., "Solid Waste Disposal and its Relationship to Estuarine Pollution," in "Estuarine Pollution Control: A National Assessment," report in preparation, U.S. Environmental Protection Agency, 1976.

2/ Coastal Plains Center for Marine Development Services, The Marine Newsletter, Vo1. 7, No. 6, p. 6, November-December 1976. 
The coastal zone is the site of most of the 2000 cargo terminals of the National Port System. $1 /$ Problems associated with port facilities are due to both shipping activities and the facilities themselves. The presence of offshore fossil fuel deposits and the need for access to port facilities continues to result in movement of many petroleum industry activities into the coastal zone. Other extractive industries such as oyster shell, sand, and gravel mining are also present to some degree in the coastal zone.2/ In the future, desalination plants may become a serious threat to estuarine biota in some areas.

There has been increasing utilization of the coastal zone for recreational activities in recent years. Expenditures for water related recreational activities was projected to increase from $\$ 3.5$ billion in 1964 to $\$ 5.7$ billion in 1975 . 2 In 1972,38 percent of the time spent by Americans on outdoor recreational activities involved water related activities. 3/ All of these factors encourage a net population movement into the coastal zone and urbanization in the vicinity of coastal industrial centers (see Section III-B-3, Municipal Activities). Population in U.S. coastal areas grew 78 percent between 1930 and 1960 , compared to the national population increase of 46 percent. The coastal zone is expected to have a population of nearly 77 million people by 1980.1 The distribution of coastal zone development and the impact on estuarine waters is shown in Table 4 .

\section{a. Sediments}

Suspended sediments may enter estuarine waters as a result of: (1) runoff from agricultural and silvicultural activities (2) suspension of bottom sediments during extraction of sand, gravel, and oyster shells, (3) dredging associated with the construction of shipping channels, (4) maintenance dredging of shipping channels, and (5) urban construction activities. In addition to smothering adult shellfish, the larval stages of many species require a hard substrate on which to settle. Should a shellfish bed or other suitable habitat be covered with silt it may be necessary to reintroduce materials for attachment of larvae before shellfish can reestablish.

1/ "An Assessment of Estuarine and Nearshore Marine Environments," SRAMSOE No. 93, U.S. Department of the Interior, Fish and Wildlife Service, March 1976.

2/ "National Estuarine Study," U.S. Department of the Interior, Fish and Wildlife Service, January 1970.

3/ Kelter, R.J., "Recreational Activities in the Nation's Estuarine Zone," in "Estuarine Pollution: A National Survey," report in preparation, U.S. Environmental Protection Agency, 1976. 
Table 4--COASTAL ZONE ACTIVITIES AND DIRECT IMPACTS

\begin{tabular}{|c|c|c|c|c|c|c|}
\hline DIRECT IMPACTS & 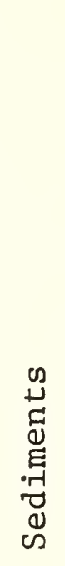 & 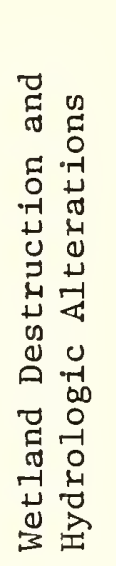 & 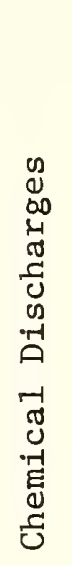 & 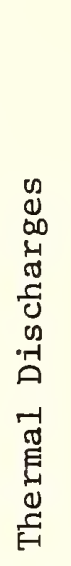 & 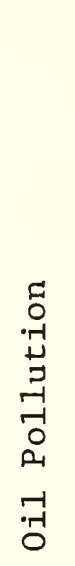 & $\begin{array}{l}0 \\
0 \\
\pi \\
0 \\
0 \\
0\end{array}$ \\
\hline Offshore oil production & & & & & $\mathrm{X}$ & \\
\hline $\begin{array}{l}\text { Port facilities } \\
\text { (coastal and offshore) }\end{array}$ & $\mathrm{X}$ & $\mathrm{X}$ & & & $\mathrm{X}$ & \\
\hline Shipping & & $\mathrm{X}$ & & & $\mathrm{X}$ & $\mathrm{X}$ \\
\hline Extractive industries & $\mathrm{X}$ & $\mathrm{X}$ & & & & \\
\hline Industrial facilities & & $\mathrm{X}$ & $\mathrm{X}$ & $\mathrm{X}$ & $\mathrm{X}$ & \\
\hline $\begin{array}{l}\text { Desalination (future } \\
\text { potential) }\end{array}$ & & $\mathrm{X}$ & $\mathrm{X}$ & $\mathrm{X}$ & & \\
\hline Agriculture, silviculture & $\mathrm{X}$ & $\mathrm{X}$ & $\mathrm{X}$ & & & $\mathrm{X}$ \\
\hline Urbanization & $\mathrm{X}$ & $\mathrm{X}$ & $\mathrm{X}$ & & $\mathrm{X}$ & $\mathrm{X}$ \\
\hline Recreation & & $\mathrm{X}$ & & & $\mathrm{X}$ & $\mathrm{X}$ \\
\hline
\end{tabular}


As described earlier, the construction of factories, refineries, marinas, vacation homes, housing developments, and means of access to them can have serious impacts on shellfish resources. These actions as well as construction and maintenance of shipping channels can drastically alter salinity characteristics of estuaries. By removing wetlands, construction may also allow water from polluted areas to flow rapidly into shellfish waters without the cleansing benefits of natural estuarine filtration. Such effects are discussed more fully in Section 6 of Appendix A.

\section{c. Discharges}

Chemical and Thermal. Shellfish are susceptible to chemical and thermal discharge because of their limited mobility. Such pollutants may directly kill shellfish, or make them less resistent to disease.1/ Chemicals may also taint the flavor of shellfish, making them inedible, or contaminate them with heavy metals such as mercury, making them a health hazard. A survey of power plant environmental reports reveals that infrequent but excessively high temperature discharges are considered environmentally acceptable by the power companies. However, lethal discharges usually occurred too frequently to allow the shellfish to reach a marketable size. Thus, it is obvious that even infrequent excessively high temperature discharges can make an area useless for shellfishing. (See Section III-B-2-c, Power Generation.)

An existing and potential problem may be operation of desalination plants. Thermal and highly saline discharges characterizing such operations could chemically destroy portions of an estuary, and also eliminate shellfish and other estuarine and marine organisms.

Petroleum. Petroleum hydrocarbon pollution is not restricted to accidental oil spills. Indeed, spills contribute only four percent of the total oil pollution in coastal waters. Urban areas, industrial facilities including coastal zone refineries, recreational activities such as boating, shipping operations, and offshore oil production contribute much greater proportions of the hydrocarbons found in coastal waters. 2 f Table 5 summarizes the amounts of petroleum hydrocarbons contributed to the coastal waters by these activities.

Proposed deep-water ports may be a future source of coastal zone oil pollution since they will require the transfer of oil from tankers to

1/ "National Estuarine Study," U.S. Department of the Interior, Fish and Wildlife Service, January 1970.

2/ Farrington, J.W., "Oil Pollution in the Coastal Environment," in "Estuarine Pollution: A National Survey," report in preparation, U.S. Environmental Protection Agency, 1976. 
Table 5--AMOUNTS OF U.S. PETROLEUM AND PETROLEUM HYDROCARBON RELEASED INTO THE MARINE ENVIRONMENT

\begin{tabular}{|c|c|c|}
\hline Source of Input & $\begin{array}{l}\text { Millions of } \\
\text { Metric Tons } \\
\text { Per Year }\end{array}$ & $\begin{array}{l}\text { Percentage } \\
\text { of Total } \\
\text { Input }\end{array}$ \\
\hline $\begin{array}{l}\text { Offshore oil production } \\
\text { (normal operations) }\end{array}$ & 0.003 & 0.2 \\
\hline $\begin{array}{l}\text { Offshore oil production } \\
\text { (accidents) }\end{array}$ & 0.01 & 0.7 \\
\hline $\begin{array}{l}\text { Oil tankers } \\
\text { (normal uperations) }\end{array}$ & 0.209 & 13.8 \\
\hline $\begin{array}{l}\text { Oil tankers } \\
\text { (accidents) }\end{array}$ & 0.03 & 2.0 \\
\hline $\begin{array}{l}\text { Other shipping } \\
\text { (normal operations) }\end{array}$ & 0.078 & 5.2 \\
\hline $\begin{array}{l}\text { Other shipping } \\
\quad \text { (accidents) }\end{array}$ & 0.02 & 1.3 \\
\hline $\begin{array}{l}\text { Industrial, urban, recreational, } \\
\text { and nonpoint }\end{array}$ & 1.16 & 76.8 \\
\hline Total input & 1.51 & 100.0 \\
\hline Total input from accidents & 0.06 & 4.0 \\
\hline
\end{tabular}

Source: Farrington, J.W., "Oil Pollution in the Coastal Environment," in "Estuarine Pollution: A National Survey," report in preparation, U.S. Environmental Protection Agency, 1976. 
pipelines. However, once the oil is in the pipeline, the risk of coastal zone contamination should be reduced, as demonstrated by experience with offshore wells that pump their oil to shore through pipelines.1/ Pollution due to normal operations of tankers in coastal waters may be lessened because of reduced traffic in estuarine areas. Nevertheless, effects of oil spills must be considered serious, since they concentrate large amounts of oil in a relatively small area. 0il discharges from sources such as shipping operations (excluding spills), offshore oil production, recreational boating, and industrial and urban sources are unlikely to have acute effects on the total resource because the concentrations are less severe than from a major spill. Chronic (long-term) effects on shellfish may be a problem, however, especially in areas of heavy coastal zone use.1/

Sewage. Septic pollution may enter estuarine waters from several sources and can result in closures of growing water for public health reasons. Inadequate sewage treatment and storm sewer runoff cause problems near urban areas. Sewage discharge from recreational boating is a problem in some shellfish areas, although this contributes only about 0.1 percent of the septic discharges in coastal waters. 2 / Few marinas in the country have pump-out facilities, and where they do exist, enforcement is so difficult that overboard discharges continue relatively unabated. Onboard waste treatment is expensive for small vessels, and accordingly, is of concern to boat owners. Onboard treatment utilizing chlorine may directly impact shellfish. Residential and vacation homes in coastal areas often contribute septic pollution because of high water tables or poor soils. Commercial shipping adversely impacts shellfisheries because of inadequate, faulty, or nonexistent onboard holding and treatment facilities for human waste. In addition, animal wastes contribute significant amounts of coliform bacteria to shellfish waters. There is an example of this last problem in the Apalachicola Bay case study (Section 8 of Appendix A).

\section{Water Resource Development}

Water resource development in the Nation's drainage basin is of particular concern because fresh water and the nutrients it transports are critical to estuaries. Alteration of natural flow patterns may result in decreased salinity or excessive saltwater incursion. Dams and impoundments level out the natural cycle of high and low flow of water to which estuarine organisms, including shellfish, are adapted. Furthermore, such structures can block the flow of nutrients normally carried to estuaries. The following paragraphs will discuss river and wetlands

1/ Farrington, J.W., "Oil Pollution in the Coastal Environment," in "Estuarine Pollution: A National Survey," report in preparation, U.S. Environmental Protection Agency, 1976.

2/ Amson, J.A., personal communications, Marine Activities Branch, Criteria and Standards Division, U.S. Environmental Protection Agency, January 1977. 
channelization, impoundment, and interbasin water transfer. The discussion will address structures, operations or activities, water quality problems, and potential or actual impacts on estuarine organisms--specifically, shellfish. The effectiveness of impact controls and trends in resource development are also presented.

\section{a. Channelization}

Waterborne commerce and flood control are prime factors affecting decisions to channelize rivers. Construction activities include dredging of river bottoms and emplacement of levees for flood and erosion control. Maintenance dredging of channels is periodically required. Where permanent flood control channels are built, downchannel scouring and erosion necessitate additional dredging.

Downstream turbidity results from suspension of bottom materials during channel construction and maintenance. This reduces light penetration for phytoplankton growth in estuarine areas, and may inundate benthic organisms including shellfish. In addition, heavier boat traffic will increase contaminants such as sanitary wastes, oils and grease, exhaust gases, and other materials.

On the Gulf Coast, a Corps of Engineers development project has the potential to significantly affect oyster resources of the lower Mobile Bay. The Tennessee-Tombigbee Waterway (Tenn-Tom) will require the dredging of 150 million cubic yards of bottom land for a 253-mile-long barge canal through western Alabama and eastern Mississippi.1/ The purpose of the Tenn-Tom is to shorten the distance and travel time for river traffic between Mobile Bay and the Tennessee River by 800 miles. However, significant increases in Bay and River traffic could precipitate accidents, waste discharges, and spill into the waterway and thus into the lower Bay. Discussion of these activities is included in Section III-B-4, Coastal Zone Development.

\section{b. Water Impoundments}

Reservoirs are often multiple-purpose projects utilized for municipal drinking supplies, industrial cooling, agricultural irrigation, flood control, hydroelectric power generation, and recreation. Lock and dam structures are primarily utilized for waterborne commerce. The Tenn-Tom project consists of five dams and ten locks. The Trinity River project, discussed later in this section, is similar but far more extensive.

Impoundment activities include dredging of channels or emplacement of levees during the construction phase. Later phases include flow augmentation to remove sediments and organic and inorganic materials from behind the structure.

1/ D. Moser, "Dig They Must, the Army Engineers, Securing Allies and Acquiring Enemies," Smithsonian, December 1976. 
A major problem with flow augmentation concerns the alteration of natural, cyclical flows of water and other substances originating from upstream sources. Flow augmentation substantially alters the natural volume and constituents of fresh water entering estuarine systems. Water is often released from two or more levels behind impoundments, resulting in a mixing of sediments and also low oxygen content water from the lower layers with fresh water from the upper layers. Heavy rains and storms facilitate releases or organic and inorganic substances accumulated behind dams. Conversely, during the dry season, low water flows with depressed oxygen levels degrade estuarine water quality. Abnormally low water increases salinity thus providing a suitable environment for molluscan predators. Impoundments also impede the natural flow of nutrients from upstream sources to estuaries.

Al1 of these impacts pose threats to the estuary and its resources, but the significance is neither well understood nor quantified. Effects of nutrient blockage by impoundments is not at a stage permitting formulation of reliable cause-effect relationships, although the situation is being investigated in Apalachicola Bay, Florida.1ㅡㄴ It is known that estuarine systems are partially dependent on organic substances originating from the breakdown of leaves, sticks, and other materials. Nutrients such as phosphorous originate in the watershed and "feed" the estuarine system and its organisms. Delay, blocking, and sudden release of nutrients is thought to be detrimental to proper estuarine function. A proposed lock and dam near Blountstown, on the Apalachicola River, Florida, is controversial because of its potential to alter water and nutrient flows into the oyster grounds of Apalachicola Bay.

The Trinity River project in Texas is one of the largest proposed water resource development projects in the Nation. 3 Interviewees identified this project as a potential threat to estuarine dynamics and shellfish resources in Galveston Bay, Texas. The natural course of the 550-mile-long Trinity River, from Dallas to Galveston Bay, will be significantly altered because of construction activities now planned. Waterborne commerce, flood control, and recreational benefits will

1) Proceedings of the Conference on the Apalachicola Drainage System, Gainsville, Florida, April 23-24, 1976, R.J. Livingston and E.A. Joyce, Jr., eds., Florida Department of Natural Resources, Marine Research Laboratory.

2/ Whitfield, W.K., Jr. and D.S. Beaumariage, "Shellfish Management in Apalachicola Bay--Past, Present, Future," Department of Natural Resources, Florida.

3/ "Status Report of Environmental Evaluations, Trinity River Project Texas," Appendix A, U.S. Army Corps of Engineers, Fort Worth District, Texas, 1975. 
result from straightening the river. About 180 miles of waterway normally traversed by barges and other river traffic would be unnecessary. Approximately 700 million cubic yards are initally to be dredged from the channel and about five million cubic yards per year will be removed for maintenance. The environmental problems associated with this project are numerous, but the long-term impact on the estuarine resources of Galveston Bay is not well understood. The alteration of river flow volume, nutrients, and natural inorganic flows into the Bay represent a few presently unquantifiable impacts. Increases in River and Bay traffic, accidents, spills, and waste discharges, pose additional threats to the Bay's waters and shellfish resources.

Based on Congressionally authorized Federal dredging projects, over 350 million cubic yards of material are to be dredged each year from several hundred locations. 1 /

\section{c. Interbasin Transfer}

Most transfers of water from one basin to another occur in the western states, but with increasing growth and development of areas on the East Coast, additional water supplies are required for drinking and for waste disposal. Water for public consumption is expected to increase from 17 percent ( 3.5 billion gallons) of the total amount drawn for all uses in 1960, to 32 percent (10.6 billion gallons) in 1980. 2 Transfer of water from one basin to another reduces fresh water in one and increases it in another. For example, transfers of water into the Patuxent River Basin, Maryland are required for handling wastes produced by a growing population within the Basin. Fifty-four sewage treatment plants account for almost half of the freshwater inflows into the River, and recent studies indicate that this percentage is expected to approach three-fourths of the freshwater inflows by the year 2000, given present growth and development trends.

\section{d. Effectiveness of Impact Controls}

Federal impact control mechanisms are derived mainly from the environmental impact statement (EIS) process under the National Environmental Policy Act (NEPA), the review and coordination procedures established under the Fish and Wildlife Coordination Act (FWCA), and the Federal Water Pollution Control Act Amendments (FWPCA). The U.S. Army Corps of Engineers has prime responsibility for control of 25,000 miles of waterways and 400 dams and man-made lakes, and is the Nation's largest single producer of hydroelectric power. While the Corps has addressed more environmental impacts in recent years, its basic philosophy consistently emphasizes

1/ "Dredged Material Research Program, Third Annual Report," Department of the Army, Corps of Engineers, January 1976.

2/ "Water Policies for the Future," Final Report to the President and to the Congress of the United States by the National Water Commission, Washington, D.C., 1973. 
continued growth and development. Resource Assessment Divisions in Corps' offices were developed in order to provide necessary perspective on impacts of proposed projects. Interviews with Resource Assessment personnel suggest that at times adversary relationships develop between themselves and Corps engineers within their planning framework.

Because there are no enforcement provisions inherent in the EIS process, findings of adverse impacts do not preclude the approval of a proposed project. While the EIS process and review-coordination activities of FWCA are helpful in assessing proposed projects, several critical problems remain. The.first is insufficient funds and personnel in other Federal agencies to provide adequate review, input, and constructive criticisms for other than the largest projects. The second problem is insufficient data to support contentions of damage or impact. Recent information on the long-term effects of water resource development activities on benthic organisms in estuarine areas sheds little light on biological impacts on mulluscan shellfish resources. Physical and mathematical models have been constructed, and predictions have been made (at times specifically in reference to effects on shellfish resources), but the complexity of estuarine dynamics raises some doubt as to the model's validity. It has been found in the course of this study that Federal agency personnel are distressed that projected impacts are based on informec guesswork rather than on substantial research. Some say that because of the subjective nature of such impact projections, and the lack of knowledge about subtle cause-effect relationships, there is a tendency to dismiss unknown or little understood impacts, especially those of long-term duration. The reason for this is clear enough, since certain parameters, such as cost/benefit ratios, while valuable, may be easily manipulated through the use of unsubstantiated and invalid assumptions.

An increasing number of water resource development projects are Congressionally authorized or under active study or consideration by the Corps. The Corps has asked Congress to deauthorize some 400 obsolete projects; but about 600 projects, dating back to the 1940 s (such as the Intracoastal Waterway) are still on the active 1ist. These proposed projects are heavily concentrated in the Mid-Atlantic and Gulf states.

\section{Long-Term Effects of Chemicals and Their Residuals}

Current1y, more than 34,000 products made from one or more of 900 chemical compounds are registered by the U.S. Environmental Protection Agency for use in the environment. $1 /$ Total 1972 production of the top 50 chemicals was approximately 397 billion pounds. 2 The

1/ Ming-Yu Li, "Pollution in Nation's Estuaries Originating from the Agricultural Use of Pesticides," in "Estuarine Pollution Control: A National Assessment," report in preparation, U.S. Environmental Protection Agency, 1976.

2/ "Activities of Federal Agencies Concerning Selected High Volume Chemicals," U.S. Environmental Protection Agency, Office of Toxic Substances, February 1975. 
number of chemical disinfectants, bacteriostats, and germicides entering the market or being considered as pesticides is continually increasing. The uncertainties connected with pesticides are of deep concern. Pesticides are compounds designed to be deadly to living things. These compounds are now familiar by name to many Americans. One of them, Kepone, was responsible for closing the James River in Virginia to harvesting of shellfish and finfish. PCBs (polychlorinated biphenyls) are found everywhere in estuarine waters of the United States; high levels of this chemical are also found in fish of the Great Lakes. Mirex, ranks fourth nationally among toxic compounds found in oysters. To the best of our knowledge, however, it has been found only in low concentrations and only in oysters in the Southeastern United States. Concentrations of Toxaphene exceeding safe levels have been found in oysters in Georgia. Although use of DDT in the United States has greatly diminished, its residuals remain, working their way up through the food chain. As it took years for the effects of these chemicals to be discovered, so it will take years for their residuals and their consequences to disappear.

Substances such as Kepone, PCBs, and heavy metals are nondegradable, persistent, and extremely toxic. Kepone was present in the sediments and water column for many years before samples revealed its existence. While Kepone was subsequently revealed as a serious threat to water quality and biological organisms, and its source identified, the only initial action taken was to close the plant that produced it.

Efforts to eliminate the presence of many toxic substances would possibly require dredging an entire river system or estuary, and impose financial burdens and create additional environmental problems. Industrial waste toxicants are present in the aquatic environment but the severity of their impact or specific corrective actions have not been identified.

Though many studies have been conducted on the effects of heavy metals in water on fish and shellfish, few action levels have been established by state or Federal agencies. During interviews, statements were made to the effect that little progress is being made, even though more data are being collected, because toxicological evidence as to the acceptable body burden is not available. Yet the potential danger is clear. As quoted elsewhere in this report, in some areas "the heavy metals, cadmium, copper and zinc, have been shown to be concentrated in shellfish four to five orders of magnitude above that of the surrounding water...." I The same study also notes that in the area of Hampton Roads, Virginia, where industrial waste appears to be contaminating oysters, the oysters from one station averaged over $6000 \mathrm{ppm}$ in zinc.

1/ Huggett, R.J.,M.E. Bender, and H.D. Stone, "Utilizing Metal Concentration Relationships in the Eastern Oyster (Crassostrea virginica to Detect Heavy Metal Pollution," VIMS Contribution No. 495, Water Research, Vol. 7. pp. 451-460, 1973. 
There are 187 toxic chemicals under some form of evaluation by the Environmental Protection Agency. If "Fina1" effluent 1imitation guidelines have been established for only 32 of these chemicals. Studies are underway to evaluate 97 of these for future listing in the "final" category. The evaluation of these toxic substances, while properly undertaken by EPA under Congressional mandate, presents difficulties because cumulative or synergistic effects on aquatic organisms are not addressed. It is valuable to know the relative toxicities of individual chemicals, yet these substances are often found in combination, and in varying concentrations in receiving waters and estuaries. The possible perturbations and alternative associations among and between the toxic chemicals listed are astronomical. The 1985 water quality goal of "no discharge" was criticized as overly restrictive and impossible to accomplish. However it is an approach to ensuring that cumulative or synergistic impacts are at least not in the array of significant problems that may arise in the future.

The effects of metals and sophisticated chemicals are often very subtle, due to long-term, low-level exposure. As a result it is difficult to identify responses, and even more importantly, to demonstrate cause and effect. The long times required for buildup and for disappearance make it all the more important to obtain the necessary information and take action at an early stage.

The problem of hazardous chemicals, including pesticides, is rapidly growing in importance. The public is increasingly aware that thousands of carcinogenic (cancer-causing), teratogenic (birth defect-causing), and mutagenic (genetic damaging) substances are being introduced into our environment. The need for research is of paramount importance. Information is virtually nonexistent on the effects of toxic substances on living systems at population or community levels. 2 /

1/ "Summary Tabulation of Selected EPA Activities Concerning Toxic Chemicals," Office of Toxic Substances, U.S. Environmental Protection Agency, Apri1 1976.

2/ "Environmental Impact Assessment, Water Quality Analysis," Technical Report, Vol. I, pursuant to P.L. 92-500, National Commission on Water Quality, April 1976. 
Estuaries are where rivers meet the sea. They are enormously complex and ever changing areas normally subject to major fluctuations in physical, chemical and biological conditions.

Estuaries provide harbors, sheltered areas for boating, fishing, swimming and recreation, and logical avenues of waterborne commerce from population centers to the sea. The same areas provide key elements of habitat and energy conversion processes for the biological systems of coastal streams and open coastal waters which support commercial and recreational fishing industries and other valued resources.

Competition and conflict with naturally occurring ecosystems began almost with the first settler. With time, burgeoning populations have generated multiple stress factors through modern technology and economic affluence which have altered the productivity of native species. This is a continuing process which may ultimately result in the demise of many more of the historically important fisheries.

Today, the welfare of the Nation's esturaries is an interest shared by several groups. Scientists are concerned with the hyrodynamics and ecological uniqueness of the freshwater/saltwater interface and the organisms therein. The public maintains a similar interest but generally from a direct user's viewpoint, such as the catch of estuarine dependent fish and shellfish. Some 70 percent of the fishes taken by recreational fishermen are totally dependent on estuaries at some stage in their life cycle.1/ Responsibilities for preserving and managing resources have been delegated to Federal, state, and local governmental agecies. Planners at all levels are concerned with consequences of urban and industrial spraw1. Currently, 53 percent of the Nation's population resides in a narrow band of shoreline roughly 90,000 miles long. $2 /$ In 1976, 447 new plants or plant expansions were planned on the navigable waterways of the United States. 3 /

Clearly, the growth of technology for resource utilization has exceeded its capabilities to assess and control undesirable consequences. Because resource use has been a major factor in establishing a large portion of our national, social, and economic priorities, most planning is geared to the most favorable cost/benefit ratio. Recently, undesirable consequences of indiscriminate resource use have become a national concern. The question to be resolved is whether a natural system can accommodate the consequences of man's activites and still survive. Optimum

1/ Ming-Yu Li, "Factors Limiting the Control of Pollution in the Nation's Estuaries Originating from the Agricultural Use Purposes," in "Estuarine Pollution: A National Survey," report in preparation, U.S. Environmental Protection Agency, 1976.

2/ "The Sixth Annual Report of the Council on Environmental Quality," Council on Environmental Quality, December 1975.

3/ Coasta1 Plains Center for Marine Development Services, The Marine Newsletter, Vol. 7, No. 6, p. 6, November-December 1976. 
planning would intelligently accommodate use of a biological system with minimal or no disturbance. Unfortunately, the mechanisms to bring about this process are not available and solutions to problems are sought after, rather than before, the fact.

The multiple attractions of an estuarine environment may lead to its degradation or destruction. Practically speaking, the many attractions of estuaries result in conflict. For purposes of discussion, resource use conflicts have been grouped into three categories; conflicts between man and nature, harvesting groups, and institutions.

\section{A. Conflicts Between Man and Nature}

Competition for use of estuaries is severe and continues to accelerate. The result is increasing conflicts between users. Many of the impacts are adverse to shellfish and other living resources and many of the damages sustained are irreversible.

A limited number of logical uses can be accommodated within the capacity of a given estuary by intelligent planning and management, but additional competing uses and subsequent impacts may be disastrous to the biological system.

Competing uses should be evaluated for impacts on shellfish and other renewable resources whenever activities are planned or are taking place. These include such activities as: Discharges of inadequately treated sewage, industrial wastes, toxic substances, heat and other wastes; discharges of nutrients or disinfectants from treated sewage; and accidential or incidental discharges of petroleum and toxic substances. Wetlands and open water areas may be destroyed by dredging, filling and spoil disposal associated with recreational, urban and industrial development; airport and highway construction, marinas, navigation projects and beach nourishment; shell, sand and gravel mining; and oil and gas development. The following may singly or jointly alter the resource: Diversion of freshwater flow for industrial, agricultural and municipal uses; modification of natural flow regimens and changes in temperature or salinity by flood control, navigation, and power generation projects; and introduction of excessive fresh water from municipal waste or industrial discharges, agricultural return flows or timberland drainage.

Additional levels of silting and turbidity result from agriculture, lumbering, urban development, highway construction, drainage, mining, and other uses. Runoff patterns are changed by new land use, dams, reservoirs, levees and interbasin diversions. Channels, waterways, and harbor and inlet developments further alter estuarine flushing and tidal exchanges. Agricultural, municipal and industrial waste discharges impact the habitat and the resources through silting and sedimentation, anoxic and toxic condition, and eutrophication. Mining of she11, sand, gravel, and other minerals as well as oil and gas production alter waterways and growing sites. 
Man's intemperatê" harvests in the past have reduced resource abundance, while his management efforts to sustain production have often provided opportunities for introductions of exotic competitors, diseases and predators.

Existing estuarine and coastal environments are now subjected to serious stresses engendered by a multiplicity of habitat changes. Although some evidence of stress and resulting changes can be identified, more often there is an absence of site-specific data by which impacts can be quantified.

\section{B. Commercial-Recreational Use Conflicts}

Interests of commercial and recreational fishermen are frequently competitive. Commercial fishermen claim that recreational interests take money from their pockets while the latter point out their right to harvest public resources. Conflicts may intensify when pollution decreases harvestable areas while at the same time, recreational pressures increase. As more shellfish areas are closed, harvesting intensity increases and the resulting stock depletion directly affects both interests. Creative resource management to retain or increase the number of resource areas may be the only way to improve the problem.

\section{Institutional Conflicts}

Although governmental agencies are mandated by law to equitably manage resources, conflicting interpretations and applications can lessen their effectiveness. A conflict over development of oil and gas may profoundly affect state-Federal relationships. California fought a decision by the Department of Interior to lease offshore lands. The State considered itself unprepared for the impact of the sale while Interior objected to delays in resource planning. Human innovation and need impacts water quality directly or indirectly and contributes to efforts to protect and manage water quality at levels satisfactory for the production and use of shellfish resources. State/Federal water quality standards (receiving water standards) and the National Pollutant Discharge Elimination System permit program are the principal pollution abatement programs directed at the regulation of shellfish growing waters.

It is evident that conflicts over resource uses exist on a number of levels and include a broad range of participants. It may be imprudent to resolve conflicts through regulatory and economic processes alone. Allocation or partitioning of resources without consideration of the ultimate viability of the resource itself would surely diminish its usefulness to all concerned parties. 
V GROWING WATER CLASSIFICATION, TRENDS, 1 / $2 / 3 /$ EVALUATION, VALUE LOSSES, AND POTENTIAL INCREASES IN PRODUCTION

High water quality is required for shellfish propagation and harvesting. Filter feeding mollusks pump large quantities of water containing dissolved or suspended materials through their systems, all of which affect their biological integrity. Juvenile free-swimming mollusks are especially vulnerable to water quality degradation from numerous man-induced and natural sources. Harvesting of adult shellfish is restricted by the sanitary conditions found to exist in the growing waters, and closures, openings, and classifications of growing waters are based on ambient sanitary conditions. The presence of coliform bacteria is the prime factor in classifying growing waters.

\section{A. Growing Water Classification}

Growing waters are classified by state health agencies according to the following categories and criteria.4/

- Approved: Waters classified by a state shellfish control agency as approved for the direct market harvesting of shellfish. Such waters have been determined to be free of hazardous concentration of pathogenic microorganisms and/or industrial wastes by sanitary survey.

- Conditiona11y Approved: Waters that meet approved criteria but are subject to periodic closure due to seasonal population changes, marina operation, or temporary malfunctioning of a sewage treatment plant discharging to the areas. The term seasonal is used by some states to denote such areas.

o Restricted: Waters controlled for harvesting by state agencies for specific purposes. Such waters may be harvested for controlled purification or relaying of shellfish. The bacterial level normally used for this classification does not exceed a median coliform most probable number (MPN) of 700/100 ml.

1/ "National Register of Shellfish Production Areas," Public Health Service, U.S. Department of Health, Education, and Welfare, 1966.

2/ "1971 National Shellfish Register of Classified Estuarine Waters," Food and Drug Administration, U.S. Department of Health, Education, and Welfare, 1971.

3/ "National Shellfish Register of Classified Estuarine Waters 1974," U.S. Environmental Protection Agency, December 1975.

4/ "National Shellfish Sanitation Program, Manual of Operations," Public Health Service, U.S. Department of Health, Education, and Welfare, 1965 (revision). 
- Prohibited: Waters closed for the harvesting of shellfish due to hazardous levels of contamination. The terms closed, restricted and condemned are in use by some states for this classification. A state control agency may, for a variety of reasons, classify an area prohibited even though the waters be safe for shellfish production--for example, areas in or near shipping lanes which are subject to contamination by untreated fecal material and oil.

- Non-Shellfish/Nonproductive Areas: This classification includes the areas that are inaccessible, or do not produce shellfish in commercial quantities, and areas that contain no shellfish but could support commercial species either by natural or aquacultural means.

Classification Criteria. Although classification of shellfish growing waters is based primarily on bacterial levels, shellfish waters are also classified for closure due to the presence of shellfish toxins, paralytic shellfish poison (PSP), radionuclides, untreated fecal contamination, and toxic industrial wastes such as mercury. I/

Closures in General. The States of Maine, Washington, Oregon, and California routinely monitor PSP, but only Maine has two permanent closures for PSP, both of which are on remote islands off the coast. California annually closes mussel and clam beds state-wide, from May 1 to October 31 due to PSP. The presence of PSP in water off the State of Alaska has resulted in closure of nearly all shellfish waters; there are three clam producing areas, located in western Prince William Sound, Cook Inlet, and the Alaskan Peninsula that contain harvestable shellfish. No areas were closed because of radionuclides between 1966 and 1974, and only one area in Texas was closed due to the presence of mercury, and it was subsequently reopened. Kepone was responsible for shellfish ground closure in the James River, but the areas were later partially reopened.

Between 1971 and 1974, the total acreage of classified estuarine she11fish areas remained essentially unchanged; only 700 acres were added in response to minor boundary enlargements. Nationwide, classified shellfish waters increased from 68.7 percent of state waters in 1971 to 71.3 percent in 1974, due, mostly, to reclassification of nearly 700,000 acres from Non-Shellfish/Nonproductive waters to Approved waters in Louisiana. Areas in the Approved category increased by over 123,000 acres during this fouryear period, while the number of Prohibited acres increased nearly 500,000 acres. Areas in the Conditionally Approved category were decreased by over 74,000 acres, mostly in Maryland, due to the adoption of an optional classification standard (fecal coliform instead of total coliform).

I/ "1971 National Shellfish Register of Classified Estuarine Waters," Food and Drug Administration, U.S. Department of Health, Education, and Welfare, 1971. 
The total area of Open, Conditionally Approved, Restricted, and Closed shellfish waters was approximately $14.6 \mathrm{million}$ acres in 1974 (Atlantic coast, 8.8 million; Pacific coast, 0.5 million; Gulf coast, 5.3 million). The total amount of Classified shellfish habitat increased by over 543 thousand acres from 1971 to 1974, the last year for which national statistics were available. Regional differences in growing water acreages were within a few percentage points of 1971 figures. EPA regions $1 /$ I, II, III, and IV showed a slight decrease in Open waters, and Region VI showed a substantial increase in Open waters ( 8 percent increase over 1971 acreage). Regions I, II, III, and IV showed increases in Closed Shellfish waters, with Region IV showing a 5.3 percent increase Region VI showed a 0.2 percent decrease in this category.

Areas in the Approved category increased by 123,121 acres nationwide from 1971 through 1974, mostly due to reclassification of nonproductive and non-shellfish producing waters.

Four states lead the Nation in total acreage available for shellfish production: Louisiana, 3.5 million; Florida, 2.3 million; North Carolina, 2.1 million; and Washington State, 2.0 million. However, the seven key shellfish producing states identified in this report were chosen on the basis of species (oyster, clams, and mussels), abundance, and distribution, as well as geographical representation of the various molluscan shellfish industries. The following is a brief review of closures in the key states identified in the body of this report, and is extracted from the 1975 Register covering the period 1971-1974.

1. Maine--The percentage of Prohibited waters increased from 8.5 percent in 1971 to 9.7 percent in 1974, continuing a trend from 1966. Approved waters decreased by 1.2 percent over that time.

2. New York--There was a slight change of 28 acres from the Open to the closed category.

3. New Jersey--A 2.8 percent decrease in Approved acreage over four years followed the 9.7 percent decrease observed from 1966 through 1971. Reassignment of acreage over the past four years was as follows: 1.2 percent increase in Prohibited waters, 0.5 percent increase in Conditionally Approved waters, and 1.0 percent increase in Restricted waters.

1/ Region I: ME, MA, RI, CT

Region II: NY, NJ

Region III: DE, MD, VA

Region IV: NC, SC, GA, FL, AL, MS

Region VI: LA, TX

Region IX: CA, HI

Region $\mathrm{X}$ : OR, WA, AK 
4. Maryland--The reclassification of 101,499 acres from the Conditionally Approved category, as shown in the 1975 Register, is in error. No major changes occurred during this period. Also, there was not increase in prohibited acreage.

5. Virginia--Approved shellfish growing waters decreased by 2.4 percent between 1971 and 1974, while Closed shellfish waters increased by an equal percentage.

6. Louisiana--Approved acreage increased from 45 percent to nearly 57 percent, and Prohibited acreage increased from 5.6 percent to over 13 percent of the total Classified waters. Most of the increase in both categories was due to the reclassification of 700,000 acres of areas previously considered nonproductive.

7. Washington--From 1971 through 1974, Approved acreage decreased, mainly due to 30,620 acres being reassigned to the Conditiona11y Approved category in Grays Harbor. Prohibited acreage increased only slightly.

\section{B. Trends in Closures}

Al1 regions except the West Coast have experienced a net increase in closures over the four year period. Closures range from a low of approximately 34,000 acres in the Mid-Atlantic States to about 300,000 acres in Louisiana/Texas (Western Gulf States). Most of the increase in closures in the Mid-Atlantic States is attributable to those in Virginia, and most of the increase in the Western Gulf (Texas/Louisiana) is the result of closures in Louisiana. However, an increase of some 500,000 acres of Open waters also occurred. All the key states except Louisiana show various degrees of losses of Open shellfish waters. All of the states except Maryland show an increase in Closed areas.

\section{Evaluation of Trends in Water Quality}

A comparison among three of the criteria, or classification categories, may be useful for evaluating trends in shellfish water quality. Open Non-Shellfish/Nonproductive areas have decreased by 1.14 million acres, while Closed Non-Shellfish/Nonproductive areas have increased by approximately 357 thousand acres. Prohibited areas have increased from 16.1 percent of shellfish waters in 1971 to 18.5 percent in 1974, a 0.6 percent per year increase. However, this represents a reduction, by one-half, of the 1.3 percent annual rate of increase observed in the previous five-year period between 1966 and 1971.

Because shellfish waters are designated Closed unless they have been surveyed, trends in closures may be somewhat misleading. For example, 
8500 acres of Closed waters were recently reopened, and 860 acres were classified Closed, resulting from a December 1976 sanitary survey on the upper New Jersey coast. 1 /

The reclassification of 700 thousand acres of Non-Shellfish/Nonproductive waters in Louisiana to productive status accounted for a substantial percentage increase in growing waters acreage, but was not attributable to increased growing water quality.

Acreage in the last category, Prohibited waters, may indicate water quality trends in the Nation's shellfish producing waters. Ten years of summary data (some of it from earlier years, is unreliable) indicate that the number of Prohibited areas is increasing at a reduced rate, nationwide. This may indicate that overall shellfish water quality, while not increasing, is at least degrading at a lesser rate than in the previous years. A significant reduction in degradation was found in Maryland, where no increase in Prohibited areas occurred from 1971 through 1974. Washington State showed only a slight increase in the Prohibited category.

Caution must be exercised in data interpretation because the state water quality inventories, required under Section 305(b), P.L. 92-500, FWPCA Amendments of 1972, neither confirm nor deny this trend. Each of the state reports has its own format, criteria for review and evaluation, and established data and information content. The result is a lack of standardized and systematized regional summaries and an a11-too-general national water quality inventory. The data and information supplied by the individual states to the EPA regional offices concerning the status and trends associated with water quality and shellfish resources is not uniform. Comparisons between neighboring states with common watersheds, between regions, and on a national scale are therefore difficult if not impossible to distinguish. Any extrapolation of data, information, and trends into either a regional or a national summary is somewhat superficial, if not meaningless.

Because the Prohibited category may be the most reliable indicator of trends in shellfish water quality, it will be necessary to keep a closer watch on the water quality trends associated with this particular category. While the Prohibited category of shellfish waters is not specifically tabulated in the Registers of 1966, 1971, and 1975, the net changes in Open and Closed areas are presented. Table 6 shows these changes from one reporting period to the next. Also, any changes occurring between January 1975 and December 1976 are reflected in the table. Reasons for typica1 closures or reopenings and the type of pollutants responsible are also given.

It can be seen from Table 6 that the prime reason for closures is inadequate or faulty waste treatment facilities that result in bacterial contamination of the growing waters. Domestic waste discharges laden with

1/ Eisele, W.J., personnal communication, New Jersey Department of Environmental Protection, 1977. 
bacteria are apparently directly related to shellfish water closures. Direct untreated discharges, chronic malfunctions of existing facilities, including overflows and bypasses, and other problems discussed elsewhere in this report all contribute to shellfish water degradation and area closures. A 1974 survey revealed that only 65 to 70 percent of treatment plants for which adequate data were available were meeting operating design criteria, while 56 percent of all the plants surveyed did not have adequate data available to evaluate performance. I/ As of January 1 , 1975, four-fifths of the estimated amount of expenditures required to reach EPA goals by July 1, 1977 remained to be spent. This implies that implementation of waste treatment facility construction has been lagging, resulting in a continuing negative impact on molluscan shellfish waters.

It seems clear that the greatest negative impact on the sanitary condition of growing waters is still the domestic waste discharges that find their way directly or indirectly into estuarine and marine waters. Siltation from upstream sources, the effects of dredging and filling operations, chemical contamination, and other problems associated with water quality and shellfish resources also contribute to the overall conditions and trends. The dollar value of losses caused by each of these additional pollutants remains variable and in most cases unknown.

\section{Estimated Value Losses Resulting from Closure of Contaminated Water to Harvesting}

\section{General}

There are examples of estimated value losses both on local and national scales. A 1969 study in Mobile Bay, Alabama, showed that during the 17-year period from 1952 through January 1968, the temporarily Open shellfishing area in Mobile Bay, supporting extensive oyster resources, was closed eight times because of substandard water quality. 27 Average annual shellfish harvests during the seasons with no temporary pollution closures were 1,024,000 pounds. Taking this figure as a base, the impact of pollution closures on oyster production was a net loss in harvestability of 109,000 pounds per year over the 17-year period, all of which occurred between the months of February and April. This loss corresponded to a landed value of $\$ 59,300$ per year. However, the true value of oysters to the community, after processing and distribution, was said to be as high as four times that amount, or $\$ 237,000$ dollars per year.

1/ "Water Quality Analysis and Environmental Impact Assessment of P.L.92-500 Technical Volume," National Commission on Water Quality, Staff Draft Report, January 1976.

2/ Gallagher, T.P., et al., "Pollution Affecting Shellfish Harvesting in Mobile Bay, Alabama," Federal Water Pollution Control Administration, August 1969. 
NET CHANGES IN SHELLFISH GROWING WATER AREAS BETWEEN 1966 AND 1976

(Thousands of Acres, Approx.)

\begin{tabular}{|c|c|c|c|c|c|c|}
\hline State & Status & $1966-1971 \underline{1 /}$ & $1971-1974-2 /$ & $1974-1975^{3 /}$ & $\begin{array}{l}\text { Reasons for } \\
\text { Opening/ } \\
\text { Closure } \\
\end{array}$ & $\begin{array}{l}\text { Type of } \\
\text { Pollutant }\end{array}$ \\
\hline ME & $\begin{array}{l}\text { Open } \\
\text { Closed }\end{array}$ & $\begin{array}{r}+651 \\
+28\end{array}$ & $\begin{array}{l}-12 \\
+12\end{array}$ & $\begin{array}{l}\text { No change } 4 / \\
\text { No change }\end{array}$ & $\begin{array}{l}\text { STP malfunc- } \\
\text { tion and } \\
\text { overloads }\end{array}$ & $\begin{array}{l}\text { Coliform } \\
\text { bacteria } \\
\text { (domestic) }\end{array}$ \\
\hline $\mathrm{NY}$ & $\begin{array}{l}\text { Open } \\
\text { Closed }\end{array}$ & $\begin{array}{r}-343 \\
-13\end{array}$ & $\begin{array}{l}-0.038 \\
+0.038\end{array}$ & $\begin{array}{l}\text { No change } \\
\text { No chan'ze }\end{array}$ & $\begin{array}{l}\text { Urban } \\
\text { runoff }\end{array}$ & $\begin{array}{l}\text { Coliform } \\
\text { bacteria }\end{array}$ \\
\hline $\mathrm{NJ}$ & $\begin{array}{c}\text { Open } \\
\text { Closed }\end{array}$ & $\begin{array}{l}-38 \\
+51\end{array}$ & $\begin{array}{r}-11 \\
+5\end{array}$ & $\begin{array}{l}+8.5 \\
+0.9\end{array}$ & $\begin{array}{l}\text { New survey } \\
\text { New survey }\end{array}$ & $\begin{array}{l}\text { Coliform } \\
\text { bacteria }\end{array}$ \\
\hline MD & $\begin{array}{l}\text { Open } \\
\text { Closed }\end{array}$ & $\begin{array}{r}+114 \\
+44\end{array}$ & $\begin{array}{r}-23 \\
-8\end{array}$ & $\begin{array}{l}\text { No change } \\
\text { No change }\end{array}$ & $\begin{array}{l}\text { STP malfunc- } \\
\text { tion or } \\
\text { overloads }\end{array}$ & $\begin{array}{l}\text { Coliform } \\
\text { bacteria }\end{array}$ \\
\hline VA & $\begin{array}{l}\text { Open } \\
\text { Closed }\end{array}$ & $\begin{array}{l}-0.1 \\
+25\end{array}$ & $\begin{array}{l}-10 \\
+80\end{array}$ & $\begin{array}{l}+58^{5 /} \\
-58\end{array}$ & $\begin{array}{l}\text { Chemical } \\
\text { contamination }\end{array}$ & $\begin{array}{l}\text { Kepone } \\
\text { Kepone }\end{array}$ \\
\hline LA & $\begin{array}{l}\text { Open } \\
\text { Closed }\end{array}$ & $\begin{array}{l}+587 \\
+193\end{array}$ & $\begin{array}{l}+414 \\
+265\end{array}$ & $\begin{array}{l}\text { No ch.ange } \\
\text { No change }\end{array}$ & $\begin{array}{l}\text { High flood } \\
\text { waters in } \\
\text { shellfish } \\
\text { areas }\end{array}$ & $\begin{array}{l}\text { Coliform } \\
\text { bacteria }\end{array}$ \\
\hline WA & $\begin{array}{c}\text { Open } \\
\text { Closed }\end{array}$ & $\begin{array}{l}+134 \\
+308\end{array}$ & $\begin{array}{l}-22 \\
+0.5\end{array}$ & $\begin{array}{l}\text { No change } \\
\text { No change }\end{array}$ & $\begin{array}{l}\text { Surveys } \\
\text { STP overloads } \\
\text { and pulp waste }\end{array}$ & $\begin{array}{l}\text { Coliform } \\
\text { bacteria }\end{array}$ \\
\hline
\end{tabular}

During the harvest season, between 1966 and 1975, it was also estimated that on a nationwide basis $\$ 226$ million in lost resource value resulted from molluscan shellfish area closures (extrapolation from the three years for which data is available to an annual average results in an estimated total resource loss of 226 million for the nine year period: \$10.5 million in 1966; $\$ 28.2$ million in 1971 ; and $\$ 29.2$ million in 1975). If The breakdown by species and by year is given in Table 7 .

1/ National Shellfish Register, 1971.

2/ National Shellfish Register, 1974.

3/ Personal communications, 1977, with state shellfish representatives.

4/ Does not include seasonal closures--e.g., as a result of heavy rains.

5/ As noted previous1y, Maryland adopted the fecal coliform standard. Changes therefore are not indicative of absolvte water quality.

6/ Approximately 58,000 acres of shellfish areas were closed due to Kepone contamination in the lower James River. Areas were reopened during 1976 but much of the growing waters do not contain harvestable quantities of shellfish.

I/ Bell, F.W. and D.R. Canterbery, "Art Assessment of the Economic Benefits which will Accrue to Commercial and Recreational Fisheries, from Incremental Improvements in the Quality of Coastal Waters," submitted to The National Commission on Water Quality, July 1975. 
The dollar losses are greatest for the oyster industry, followed by clams and mussels, but without exception the value losses have increased for all species from 1966 to 1975.

\section{Table 7}

SUMMARY OF VALUE LOSS--ALL SPECIES

\begin{tabular}{|c|c|c|c|}
\hline Species & 1966 & 1971 & 1975 \\
\hline Oysters & $\$ 7,005,243$ & $\$ 17,486,457$ & $\$ 18,017,693$ \\
\hline Clams & $3,533,836$ & $10,643,255$ & $11,069,088$ \\
\hline Mussels & 14,019 & 82,840 & 99,518 \\
\hline Total & $\$ 10,533,098$ & $\$ 28,212,552$ & $\$ 29,186,299$ \\
\hline
\end{tabular}

\section{Losses of Resource and Habitat}

The value of losses accruing from habitat destruction, hydrological changes, and toxic chemicals is difficult to quantify. However, as mentioned in Section III-A-2, 6000 to 7000 acres of oyster reefs were smothered in Texas over a 36-year period. No figures were otherwise available to assess shellfish resource losses in terms of dollar amounts, but the impacts associated with these factors are discussed in the preceding sections.

\section{E. Potential Increases in Domestic Catch}

It has been estimated that increases in biological productivity accruing from water quality improvements related to implementation of the FWPCA Amendments of 1972 could increase nationwide catches, between 1972 and 1985, by 717 million pounds for oysters and 165 million pounds for clams. I/ This translates to increases in productivity of 84.5 percent for oyster harvesting and 88.5 percent for clam harvesting (Table 8 ).

However, assumptions were that full implementation of FWPCA would be in effect, and that a greatly expanded resource base would be paralleled by proportionately expanded industry activities, the first of which is improbable during the present year, and the second questionable (see Washington case study, Appendix A).

1/ "Water Quality Analysis and Environmental Impact Assessment of P.L. 92-500, Technical Volume," National Commission on Water Quality, Staff Draft Report, January 1976. 
Table 8

ESTIMATED POTENTIAL INCREASE IN DOMESTIC CATCH (1972-1985) BY

SPECIES AND STATE DUE TO IMPACT OF P.L. 92-500 ON WATER

QUALITY AND THEREFORE BIOLOGICAL PRODUCTIVITY

(Round Weight) $\underline{1}$

OYSTERS

\begin{tabular}{|c|c|c|c|c|c|}
\hline \multicolumn{3}{|c|}{ OYSTERS } & \\
\hline State & $\begin{array}{l}\text { Increase in } \\
\text { Catch (thou- } \\
\text { sands of } \\
\text { pdunds) } 2 / \\
\end{array}$ & $\begin{array}{c}\text { Percentage } \\
\text { Increase } \\
1985 / 1972 \\
\end{array}$ & State & $\begin{array}{l}\text { Increase in } \\
\text { Catch (thou- } \\
\text { sands of } \\
\text { pounds) } 2 / \\
\end{array}$ & $\begin{array}{c}\text { Percentage } \\
\text { Increase } \\
1985 / 1972 \\
\end{array}$ \\
\hline $\mathrm{ME}$ & -- & -- & $\mathrm{ME}$ & 14,616 & $74.1 \%$ \\
\hline $\mathrm{NH}$ & -- & -- & $\mathrm{NH}$ & -- & -- \\
\hline MA & 231 & $152.8 \%$ & MA & 2,875 & 152.8 \\
\hline $\mathrm{RI}$ & 69 & 140.8 & $\mathrm{RI}$ & 19,598 & 138.6 \\
\hline CT & 183 & 10.5 & $\mathrm{CT}$ & 238 & 10.6 \\
\hline NY & 1,855 & 10.9 & NY & 33,757 & 51.4 \\
\hline $\mathrm{NJ}$ & 35,120 & 133.9 & $\mathrm{NJ}$ & 8,913 & 68.1 \\
\hline $\mathrm{DE}$ & 820 & 10.5 & $\mathrm{DE}$ & 55 & 10.6 \\
\hline MD & 371,080 & 127.3 & MD & 73,220 & 133.3 \\
\hline VA & 91,629 & 127.3 & VA & 7,490 & 127.3 \\
\hline $\mathrm{NC}$ & 6,645 & 92.4 & NC & 1,335 & 81.4 \\
\hline $\mathrm{SC}$ & 1,060 & 6.2 & $\mathrm{SC}$ & 17 & 6.2 \\
\hline GA & 830 & 35.7 & $\mathrm{GA}$ & -- & - \\
\hline FL & 15,234 & 29.7 & FL & 1,054 & 65.3 \\
\hline $\mathrm{AL}$ & 9,083 & 55.5 & $\mathrm{AL}$ & -- & -- \\
\hline MI & 12,903 & 69.1 & MI & -- & -- \\
\hline $\mathrm{LA}$ & 65,885 & 48.9 & LA & -- & -- \\
\hline $\mathrm{TX}$ & 61,721 & 102.6 & $\mathrm{TX}$ & -- & -- \\
\hline $\mathrm{CA}$ & 9,436 & 63.0 & $\mathrm{CA}$ & -- & -- \\
\hline OR & 2,958 & 69.3 & OR & 53 & 46.1 \\
\hline WA & 30,183 & 28.8 & WA & 2,130 & 46.6 \\
\hline $\mathrm{AK}$ & -- & -- & $\mathrm{AK}$ & 75 & 12.6 \\
\hline HI & -- & -- & $\mathrm{HI}$ & -- & -- \\
\hline $\begin{array}{l}\text { National } \\
\text { Totals } \\
23 \text { States }\end{array}$ & $716,9252 /$ & $84.5 \%$ & & $165,425 \underline{2 /}$ & $88.5 \%$ \\
\hline $\begin{array}{ll}\text { 1/ } & \text { F.W. } \\
& \text { will } \\
& \text { Impro } \\
& \text { Commi } \\
\text { 2/ } & \text { Cumul }\end{array}$ & $\begin{array}{l}\text { Bell and E.R. } \\
\text { Accrue to Com } \\
\text { ovements in th } \\
\text { ission on Wate } \\
\text { lative from } 19\end{array}$ & $\begin{array}{l}\text { interbery, " } \\
\text { cial and Re } \\
\text { quality of C } \\
\text { quality, Ju1 } \\
\text { to } 1985 \text {. }\end{array}$ & $\begin{array}{l}\text { ssessme } \\
\text { tiona1 } \\
\text { a1 Wate } \\
75 \text {. }\end{array}$ & $\begin{array}{l}\text { of the Econo } \\
\text { sheries from } \\
\text { " submitted }\end{array}$ & $\begin{array}{l}\text { Benefits } \\
\text { remental } \\
\text { National }\end{array}$ \\
\hline
\end{tabular}


The economic benefits accruing from EPA's construction grants program seem to outweigh the costs, in the long run. "High levels of public expenditures would add to stimulative impacts and lessen inflationary impacts."I/ Expenditures for municipal treatment facilities would undoubtedly benefit the water quality of estuarine and marine areas due to the decreased bacterial loadings. The National Commission on Water Quality states that improved water quality would benefit both watermen and seafood processors. Expanded opportunities for commercial harvesting of shellfish are said to be quantifiable benefits resulting from attainment of 1983 interim water quality goals under FWPCA. Specifically, reopening shellfish areas now closed to harvesting would increase production and provide economic benefits to watermen. Also, aesthetic and recreational benefits and increased land values would accrue to others.

\section{F. The Nationa1 Shellfish Register}

To date, the National Shellfish Register of Classified Estuarine Waters (The Register) has been the principal compilation of data on acreages and causes for closure by states under the National Shellfish Sanitation Program. Information and data contained in the Register were first published as a single table by the Shellfish Sanitation Branch, Public Health Service, DHEW, in 1964. The 1966 Register was published in an expanded form with information and several tables of data including categories of classification and acreage for each of the shellfish producing states. The 1971 Register was published by the Food and Drug Administration, which by then had jurisdiction over the shellfish sanitation program. It also was an expanded and updated version of Classified growing waters and the figures were more accurate. Responsibility for publication of the 1974 Register was placed with the National Enforcement Investigation Center, EPA, Denver, Colorado, and it too expanded upon previous Registers. The EPA Center in Denver has expressed a "lack of interest" in participating in the publishing of the next Register, which would normally be out in 1977 or 1978; no data collection process is ongoing. It was suggested that the FDA, Washington take over the duties because of their shellfish responsibilities. When contacted, however, the FDA Shellfish Sanitation Branch indicated that it was not planning such a move. No future Register is planned, and the responsibility for data collection and publication is now uncertain.

The Register is seriously needed as a shellfish resource management and program evaluation tool. If prepared annually and if State supplied information were standardized and expanded, it would permit a yearly analysis of water quality trends and the effectiveness of pollution abatement programs in making resources available. Widespread or particularly persistent problems or any new or special problems could then be isolated for prompt attention by appropriate agencies.

\footnotetext{
1/ "Water Quality Analysis and Environmental Impact Assessment of P.L. 92-500 Technical Volume," National Commission on Water Quality, Staff Draft Report, January 1976.
} 


\section{G. Summary}

Based on increases in Prohibited areas in 1971-74, degradation of shellfish growing waters is continuing, but nationally only at half the rate of the 1966-1971 period. Several states show decreases or little or no increase in Prohibited areas, while others show significant increases. The lack of universal standards for classification of waters and record keeping makes absolute change difficult to discern.

The National Shellfish Register of Classified Estuarine Waters is an important shellfish resource management tool. It should be published annually. Its basic data should be standardized and expanded as a mechanism for evaluating trends in resource availability and identifying major management problems in water quality. 
This section describes the nature of Federal laws that affect water quality and the shellfish environment and appraises their effectiveness in dealing with the water quality problems described in Section III. The appraisal is based on observations of the law itself (i.e., legislative history, statutory provisions, and key court decisions), reports published by Federal agencies describing problems and progress in carrying out programs under the laws, visits to geographically dispersed sites, and interviews carried out by members of the study team. More details regarding each law may be found in Appendix $B$, and the findings resulting from the site visits are presented in the case studies in Appendix A.

While this section describes a number of Federal laws, the primary focus of this section is on the major laws affecting (1) waste discharge, and (2) water quality. The first three listed below deal primarily with the former, while all four deal with water quality in general.

- Federal Water Pollution Control Act Amendments of 1972. I/

- Marine Protection Research and Sanctuaries Act of 1972, as amended. 2 /

- Fish and Wildlife Coordination Act of 1958. 3 /

- Rivers and Harbors Act of 1899. 4/

Another important law is the Coasta1 Zone Management Act of 1972 which, through designation of area use, can be extremely helpful in achieving the objectives of the four acts listed above.

Clearly the most significant water quality statute is the Federal Water Pollution Control Act (FWPCA). The law's objective is to restore and maintain the Nation's waters (1) by achieving a level of water quality that provides for the protection and propagation of fish, shellfish, and wildife, and allows for recreation in and on the water by July $I$, 1983, and (2) by eliminating the discharge of pollutants into U.S. waters by 1985 .

\section{A. Federal Water Pollution Control Act Amendments of 1972 (FWPCA)}

The approach of FWPCA is to achieve good water quality by controlling the discharge of all pollutants at the source of the discharge. In the case of an identifiable point source, such as an industrial discharge,

1/ P.L. 92-500, 33 U.S.C. 1251 et seq.

2/ P.L. 92-532, 33 U.S.C. 1401 et seq.

3/ P.L. 85-624, 16 U.S.C. 661-664.

4/ 30 Stet. 1151-54, 33 U.S.C., 401 et seq. 
this procedure may be rather straightforward. It is more difficult when pollutants are washed by rainfall from fields and roadways into estuarine areas (nonpoint source or uncontrolled runoff). Nevertheless, the act is comprehensive and includes all sources of all pollutants. The elements of the act's regulatory approach are as follows:

- Technology-based effluent limitations for existing industrial facilities discharging waste water directly into U.S. waters.

- Technology-based effluent limitations for new industrial facilities discharging directly into U.S. waters.

- Pretreatment requirements for industrial facilities discharging into municipal treatment works.

- Effluent limitations for publicly-owned treatment works.

- Water quality related effluent limitations applicable to all dischargers into certain waterways.

- Guidelines for discharges into the oceans. 1/

- Continuation, upgrading, and extensign of Federal-state receiving water quality standards. $\underline{2}$

- Special attention to toxic discharges.

- Performance standards for marine sanitation devices.

- A nationwide discharge permit program.

o Permit program for discharge of dredged material or fill in navigable waters.

- Detailed inspection and monitoring provisions.

- Provision for enforcement.

- Extensive requirements for interstate, state, and local planning and implementation programs.

Among its numerous provisions are four major regulatory functions which have the greatest and perhaps most direct impact of any Federal law concerning water quality on molluscan shellfish resources within the threemile limit, and therefore on the molluscan shellfish industry as a whole.

1/ These guidelines are also applicable to ocean dumping. See discussion of Marine Protection, Research, and Sanctuaries Act, herein.

21 These Federal-state water quality standards were developed under a prior water quality statute. 
The four functions are (1) the Water Quality Standards Program which establishes levels of quality suitable for shellfish growth and harvest; (2) the NPDES Permit Program under which virtually all point source discharges are Identified and quantified, and under which waste treatment and discharge limitations are specified, and discharge monitoring requirements established; (3) the Marine Sanitation Device Program under which sewage discharges from watercraft are controlled; and (4) the dredged and fill material placement program under which discharges to navigable waters are controlled.

\section{Water Quality Standards}

The FWPCA (Section 303) provides for the establishment of water quality standards. These pertain to water quality within a receiving water body as contrasted with effluent standards which apply to the quality of a waste effluent discharged to the receiving water.

A major consideration in the establishment of receiving water standards is that the attainment of high water quality required for propagation and protection of aquatic life, including the harvest of shellfish, does not prohibit any other legitimate human use of that water body, even though a lower quality may satisfy the minimum requirements for the other uses.

A water quality standard consists of four parts:

(1) A classification of use for the body of water on which the standard is being set. Uses include, among others, public water supply, industrial water supply, fish and wildlife, aquatic life (warm water, cold water, etc.), shellfish harvest, recreation, aesthetics, navigation and agricultural water supply.

(2) A definition of criteria for water quality parameters (e.g., dissolved oxygen, $\mathrm{pH}$, temperature, coliforms, toxics and others) necessary to support specific uses for which the water has been classified. Criteria are usually, but not always, expressed as numerical limits above or below which a given parameter in the receiving water may not be exceeded as a result of waste discharges. They are usually considered the lower limits of quality and if exceeded might damage the classified use. Discharges of certain substances may be prohibited.

(3) An implementation schedule establishes dates when the established criteria are to be met.

(4) An antidegradation clause provides for existing water quality that was higher than the declared criteria on the date the standard was set. This water quality is not to be degraded below that higher level except in accordance with certain specified procedures. 
Standards include other substantial conditions essential to their proper administration. One major provision affects water classified for more than one use. In this case, the more stringent of the several criteria established for each parameter applies.

Water quality standards are set by the states and are administered and enforced by the states. The Administrator of EPA has authority to approve the adequacy of the state-established standards and can promulgate such standards if the states' standards are deficient. EPA does provide guidance as to the adequacy of criteria and standards.

In accordance with Section 303, the water quality standards of each state are to be reviewed at least every three years by the state in order to determine if modifications are required.

The water quality criteria for fish, wildlife and aquatic life are, for almost all parameters, more stringent than those for any other use. The criteria set for molluscan shellfish are generally the same as for the protection of the other organisms growing in the same aquatic community, with the exception that the coliform criteria are more stringent.

The coliform criteria is set for the protection of those who might consume the raw shellfish, rather than to protect the shellfish themselves. The coliform criteria has been 70 total coliforms per $100 \mathrm{~m} 1$, using a median MPN, with no more than 10 percent of the values exceeding 230 for the 5 tube test. EPA has concluded that 70 total coliform MPN per $100 \mathrm{ml}$ at the $50 \mathrm{th}$ percentile, is equivalent to a fecal coliform MPN of 14 per $100 \mathrm{ml}$ and now recommends a fecal coliform criteria for shellfish harvesting waters of $14 \mathrm{MPN}$ per $100 \mathrm{ml}$ with not more than 10 percent of samples exceeding $43 \mathrm{MPN}$ for a 5 tube test. All states now use one or the other of these criteria for coliform levels in waters classified for shellfish harvest.

Most if not all states have had water quality standards under some state authority for at least some of their waters for many years. The Federal Water Pollution Control Act of 1965 called for the establishment of Federally approved standards for all interstate and certain coastal waters. Every state submitted standards by mid-1967 for approval by the Secretary of the Interior and the majority of these were approved by early 1969. However, certain components of several standards were the subject of Federal/state disagreement and some of those remained unresolved until the passage of P.L. 92-500. That act established a procedure and cutoff date for approval of any outstanding water quality standards. It also expanded the authority for Federal overview of water quality standards to cover intrastate as well as interstate and coastal waters. The water quality standards which were then outstanding have since been approved. Most, if not all, states are now engaging in, or have recently carried out a review of their water quality standards to determine if modifications are called for. The majority of the states classified all of their waters for some form of use by fish and aquatic life and set criteria to 
protect that use. The use generally provided for propagation as well as growth and other life requirements of the organisms. In a few cases, such as heavily polluted harbors, standards were set only to guarantee the transit of migrating fish.

Most shellfish harvesting waters were classified for this use by the states, but in many cases the areas, or portions of them, could not meet the criteria and were not open to shellfish harvest. The states recognized this as the objective of the pollution abatement program when the standards were set, but established the classification based on "intended use." Some states established lower grade shellfish waters so that clams could be taken for depuration. This survey did not determine the exact distribution of waters that are now either open or closed to shellfish harvest. However, Section V-B, Trends, discusses the trends in open versus closed areas and provides some acreage data.

Should the Act's total regulatory scheme be fully implemented, it would appear that the act's water quality goals could be achieved. However, EPA's "National Water Quality Inventory" I/ reveals that as of 1975 , many severe water problems continue to exist. These problems have negative consequences for molluscan shellfish beds. This fact was confirmed by the study team on its site visits. Valuable clam beds off the coast of Maine have been closed due to water pollution since 1972. In Louisiana, between the years 1971 and 1974, 300,000 acres of shellfish habitat were closed because of pollution. To illustrate the complexity of the situation, southeast Nassau County on Long Island, New York is completely serviced by municipal treatment works. yet its shellfish beds remain closed because of pollution from other sources such as storm-water runoff.

The reason for these failures may be simply stated; the law is not yet fully implemented. A companion EPA document entitled "Clean Water" 2 / describes a multitude of problems, including technical problems, research needs, manpower limitations, economic "realities," monitoring and enforcement problems, and intergovernmental difficulties. These problems will be referred to specifically in discussion of the implementation of the act.

\section{Effluent Limitations and the National Pollutant Discharge Elimination System (NPDES)}

Effluent limitations are provided for by several sections of Title III of the act. Section 402 establishes the NPDES which provides for issuance of waste discharge permits as a means of identifying, defining, and where

I/ "National Water Quality Inventory, 1975 Report to Congress," U.S. Environmental Protection Agency, EPA-440/9-75-104, 1975

2/ "Clean Waters, Report to Congress 1975-1976," U.S. Environmenta1 Protection Agency, (1976). 
Table 9

NPDES PERMIT PROGRAM

States and Territories

(alphabetical listing)

\begin{tabular}{|c|c|c|c|}
\hline & Approved & & Not Yet Approved \\
\hline 1. & California* & 1. & Alabama* \\
\hline 2 . & Colorado & 2 . & Alaska* \\
\hline 3. & Connecticut* & 3. & Arizona \\
\hline 4 . & Delaware* & 4 . & Arkansas \\
\hline 5. & Georgia* & 5. & District of Columbia \\
\hline 6. & Hawaii & 6. & Florida* \\
\hline 7. & Indiana & 7. & Guam and Trust Territories \\
\hline 8 . & Kansas & 8. & Idaho \\
\hline 9. & Maryland* & 9 . & Illinois \\
\hline 10 . & Michigan & 10 . & Iowa \\
\hline 11. & Minnesota & 11. & Kentucky \\
\hline 12 . & Mississippi* & 12 . & Louisiana* \\
\hline 13. & Missouri & 13. & Maine* \\
\hline 14. & Montana & 14 . & Massachusetts* \\
\hline 15 . & Nebraska & 15. & New Hampshire* \\
\hline 16. & Nevada & 16. & New Jersey* \\
\hline 17. & New York* & 17 . & New Mexico \\
\hline 18. & North Carolina* & 18. & Oklahoma \\
\hline 19. & North Dakóta & 19. & Pennsylvania \\
\hline 20. & Ohio & 20 & Puerto Rico \\
\hline 21 & Oregon* & 21. & Rhode Island* \\
\hline 22. & South Carolina* & 22 . & South Dakota \\
\hline 23 . & Vermont & 23. & Tennessee \\
\hline 24. & Virgin Islands & 24 . & Texas* \\
\hline 25 . & Virginia* & 25 . & Utah \\
\hline 26. & Washington* & 26. & West Virginia \\
\hline 27 . & Wisconsin & & \\
\hline 28 . & Wyoming & & \\
\hline
\end{tabular}

Derived from information received from the Water Enforcement Section, Enforcement Division, U.S. Environmental Protection Agency, Washington, D.C., September 29, 1976.

*Indicates a molluscan shellfish resource commercially or recreationally harvested in the continental United States. 
necessary controlling virtually all point source discharges. This section also provides that EPA establish and administer the NPDES permit program as a Federal program except in those cases where the state asks to assume its operation and is certified by EPA as qualified to do so. EPA is the principal enforcing agency for Federal NPDES permits. The states are responsible for enforcement where they have assumed control of the program, but EPA has overview authority and can take legal action for permit violations if the state proves unable to do so. As of September 29, 1976, 27 states and the Virgin Islands had received approval from EPA to run their own NPDES programs (see Table 9). Twelve of the twenty two shellfish producing states in the continental United States have been granted control of their NPDES programs.

A permit will contain such information as the required effluent limitations, process requirements, schedule of compliance, and monitoring requirements. The public is given notice and may comment on the proposed permit. Federal and state fish and wildlife agencies pursuant to the Fish and Wildlife Coordination Act also have an opportunity to comment on the probable impact for fish and wildife should the permit be issued. 1 /

After the permit is issued, follow-up is necessary to ensure that discharges are in compliance with abatement schedules and are meeting effluent limitations. In its "Report to Congress 1975-76," 2/ EPA indicated that it will turn its attention now to compliance monitoring and enforcement. It seems unlikely that it has the manpower to do this for all states and territories that do not have an approved NPDES plan, and concurrently oversee the permitting actions of those states that do. This seems especially true in light of the March, 1975 district court case that held that EPA must include, in its NPDES program, permitting for certain feedlots, separate storm sewer outfalls, and certain agricultural and silvicultural discharges. 3/ EPA estimates there are 1.8 million feedlots in the Nation, and the cost of processing and issuing permits to these feedlots would exceed $\$ 1$ billion. EPA is appealing the decision. 4/

It appears that EPA probably cannot look to the states for all the necessary enforcement action. For example, in Virginia there is a backlog of 2,000 violations going unprocessed because of manpower limitations (see Virginia case study in Appendix A). The following is taken from the

1/ See discussion under Fish and Wildlife Coordination Act, herein.

2/ "Clean Water: Report to Congress, 1975-76," U.S. Environmental Protection Agency, 1975.

3/ Natural Resources Defense Council v. Train, 396 F. Supp. 1393, (March 24, 1975).

4/ "Implementing the National Water Pollution Control Permit Program," Comptroller General of the United States, February 9, 1976. 
New York case study in Appendix A:

"Pollution from industrial plants and electrical plants is moderately controlled. Most plants are under permit or at least pending permit. The problem is basically enforcement. Monitoring is infrequent in most cases due to lack of manpower."

In the Apalachicola Bay case study it was noted that arbitrary enforcement by EPA has led to a lack of cooperation by those holding permits. The EPA regional office in Atlanta indicated that it was wary of reports that provided the same monitoring data month after month.

An accurate evaluation of the effectiveness of the National Pollution Discharge Elimination System is made difficult by the lack of current information on both Federal and State program performance, by conflicting data, and by noncompliance. EPA is apparently dependent on the state performance reports required under Section 305(b) for much of its performance information. The reporting system is not adequate and there is a lack of consistency in data between the various state reports. Therefore, national, regional or intrabasin comparisons are difficult, and in many cases could be meaningless or misleading. Some state reports lack meaningful data on the status of the shellfish waters, and some of the reporting problems stem from the way the reporting requirement has been administered.

EPA headquarters left the decision on format, specific criteria for review, and minimal reporting requirements of the 305 (b) reports to each region and/or state. The states did not use a standard approach and thus the data are not uniform. The states are reluctant to switch over to a uniform system and as a result there is not standardized, systematized national water quality inventory. One of the conflicting data problems stems from the fact that reissued permits are included in the total number of permits issued. Another is that large plants having several outfall points may be reported as a single discharger even though more than one permit may have been issued.

Noncompliance may be illustrated by recent EPA information. Nationwide permit datal show that, as of September 30, 1976, 88 percent $(19,359)$ of the identified municipal dischargers $(21,985)$ and 78 percent $(33,364)$ of

I/ "EPA Formal Reporting System's State Activity Report," Permits Section, Water Enforcement Branch, Enforcement Division, U.S. Environmenta1 Protection Agency, 1976. 
the identified nonmunicipal dischargers $(42,892)$ have been issued permits. EPA estimates in their 1975-76 "Clean Water" report that 50 percent of the municipal discharges with permits will be in compliance by 1977 . This means that approximately 12,350 municipal dischargers will either not be in compliance with their permits or else not have an NPDES permit.

As of January 1977, EPA has identified approximately 38,000 industrial dischargers nationwide, issued 29,000 industrial NPDES permits, and estimates that 90 percent of these permits will be in compliance by July 1977. 1f This means that approximately 26,000 industrial dischargers are expected to be in compliance, and 12,000 industrial dischargers will either not be in compliance or else not have an NPDES permit. Table 10 indicates the status of permits issued for the 23 coastal states (including Hawaii) based on EPA's 1976 state activity report. According to these data 90 percent of the identified municipal discharges and 74 percent of the identified nonmunicipal dischargers have been issued permits. If EPA's national estimate of 50 percent compliance with municipal discharge permits is applied to the data for the seven selected coastal states, one would expect for 1977 that 1978 municipal dischargers would be in compliance and 1932 municiipal dischargers will either not be in compliance, or else not have an NPDES permit. In conducting interviews witn regional EPA officials, the study team learned that the estimate for municipal compliance may be as low as 30 percent for some regions; thus the 50 percent estimate may be optimistic.

The number of the dischargers and permits 1isted in Table 10 which are sited directly on shellfish waters or tributary streams was not determined in the survey. Therefore, it is not possible to estimate the direct effect of these actions on shellfish resources.

In any evaluation of the effectiveness of the act and its implementation, it is important to consider that the law has been in effect for only four years and there are important time considerations in its implementations. Time was required to establish permit criteria for effluent guidelines, regulations, and waste treatment technology; to process and issue permits; and to construct facilities required by the permits. In many castes operating time is required for the receiving waters and the attendant ecological system (indicators) to recover from the years of abuse.

If Bill Jordan, personal communication, Chief, Industrial Permits Branch, Permits Division, U.S. Environmental Protection Agency, January, 1977 . 
Table 10

STATE-BY-STATE BREAKDOWN OF NPDES PERMITS ISSUED BY STATES AND EPA PROGRAM STATUS FOR THE 23 COASTAL STATES SEPTEMBER 30,1976

\begin{tabular}{|c|c|c|c|c|c|c|}
\hline \multirow[b]{3}{*}{ State } & \multicolumn{3}{|c|}{ NEW ENGLAND REGION } & & & \\
\hline & \multicolumn{3}{|c|}{ Municipal $\underline{l}$} & \multicolumn{3}{|c|}{ Non-Municipal $1 / 2 /$} \\
\hline & $\begin{array}{l}\text { No. of Iden- } \\
\text { tified Dis- } \\
\text { charges } \\
\end{array}$ & $\begin{array}{l}\text { No. of } \\
\text { Permits } \\
\text { Issued } \\
\end{array}$ & $\begin{array}{l}\text { Percent } \\
\text { Issued } 3 \text { / }\end{array}$ & $\begin{array}{l}\text { Identi- } \\
\text { fied Dis- } \\
\text { charges } \\
\end{array}$ & $\begin{array}{l}\text { Permits } \\
\text { Issued } \\
\end{array}$ & $\begin{array}{l}\text { Percent } \\
\text { Issued } 3 /\end{array}$ \\
\hline $\mathrm{CT}^{4}$ I & 141 & 125 & 89 & 518 & 510 & 98 \\
\hline ME & 198 & 177 & 89 & 403 & 377 & 94 \\
\hline MA & 212 & 161 & 76 & 768 & 550 & 72 \\
\hline $\mathrm{NH}$ & 104 & 100 & 96 & 190 & 179 & 94 \\
\hline RI & 41 & 32 & 78 & 193 & 162 & 84 \\
\hline Subtotal & 694 & 595 & 86 & 2,072 & 1,778 & 86 \\
\hline \multicolumn{7}{|c|}{ MID-ATLANTIC REGION } \\
\hline $\mathrm{NY}^{4} /$ & 1,067 & 1,209 & $113^{5 /}$ & 1,324 & 882 & 67 \\
\hline NJ & 528 & 415 & 79 & 815 & 546 & 67 \\
\hline $\mathrm{DE}^{4 !}$ & 79 & 63 & 80 & 105 & 163 & 155 \\
\hline $\mathrm{M}^{4} 4$ & 421 & 336 & 80 & 695 & 579 & 83 \\
\hline $\mathrm{VA}^{4} /$ & 848 & 826 & 97 & 1,022 & 878 & 86 \\
\hline Subtotal & 2,943 & 2,849 & 97 & 3,961 & 3,048 & 77 \\
\hline \multicolumn{7}{|c|}{ SOUTH ATLANTIC-GULF REGION } \\
\hline $\mathrm{Nc} 4 !$ & 372 & 181 & 49 & 948 & 1,069 & $113^{\prime \prime}$ \\
\hline $\mathrm{sc}^{4 /}$ & 407 & 326 & 80 & 505 & 993 & $197 \underline{5} /$ \\
\hline $\mathrm{GA}^{4} /$ & 552 & 262 & 53 & 552 & 479 & 87 \\
\hline FL & 335 & 320 & 96 & 957 & 913 & 95 \\
\hline $\mathrm{AL}$ & 271 & 265 & 98 & 566 & 548 & .97 \\
\hline $\mathrm{MS}^{4 /}$ & 382 & 365 & 96 & 726 & 811 & 1125 \\
\hline LA & 351 & 301 & 86 & 3,062 & 479 & 16 \\
\hline $\mathrm{TX}$ & 922 & 945 & $1025 /$ & 3,324 & 1,277 & 38 \\
\hline Subtotal & 3,592 & 2,965 & 83 & 10,640 & 6,569 & 62 \\
\hline \multicolumn{7}{|c|}{ WEST COAST-PACIFIC REGION } \\
\hline $\mathrm{CA} \frac{4 /}{4}$. & 396 & 372 & $101 \frac{5}{5}$ & 1,552 & 1,621 & $104^{5 /}$ \\
\hline OR $\frac{4}{4} /$ & 292 & 292 & $100 \frac{5 /}{51}$ & 551 & 510 & 93 \\
\hline WA 4 & 297 & 292 & $98^{5}$ & 638 & 642 & $1015 /$ \\
\hline $\mathrm{AK}^{\prime}$ & 54 & 46 & 85 & 589 & 510. & 87 \\
\hline $\mathrm{HI} \underline{4}$ & 24 & 43 & $1795 /$ & 145 & 188 & $130^{5}$ \\
\hline Subtatal & 1,046 & 1,070 & 10251 & 3,445 & 3,471 & $101 \underline{5} /$ \\
\hline TOTAL & 8,275 & 7,479 & 90 & 20,118 & 14,866 & 74 \\
\hline
\end{tabular}

Source: "EPA Formal Reporting System's State Activity Report," Permits Section, Water Enforcement Branch, Enforcement Division, U.S. Environmental Protection Agency, Washington, D.C., 1976

1/ Includes major and minor dischargers, according to EPA Permits section, Washington, D.C., private conmunication. A major nonmunicipal discharger is one that discharges over 50 thousand gallons per day; or discharges toxic substances; or is designated a major discharger by a state authority due to special circumstances or considerations; or whose discharge may affect another state. A major municipal discharger is one that discharges over five million gallons per day; or serves a population greater than 10 thousand; or discharges more than 250 thousand gallons per day and has an FWPCA construction grant; or recelves waste from a major non-municipal source.

2/ Includes industrial, agricultural, silvicultural, and Federal facility activities.

3/ Percentage of identified dischargers to whom permits have been issued. States with approved NPDES program under Section 402, P.L. 92-500, FWPCA Amendments of 1972 , as of September $30,1976$.

5/ Note: The number of permits issued exceeds the number of source identified in some cases. The primary reason for this is that reissued permits are included in the number of permits issued. Another factor is that certain large plants having several outfall pipes are reported as a single discharger even though more than one permit may be issued. EPA hopes to rectify this source of confusion by publishing separate data for issued and reissued permits during the coming year. 
The entire story is not told by the number of permits issued as of a certain date although the time when all permits are issued is critical to the achievement of the goals for each waterway. The real measure of effectiveness is implementation. It is necessary to consider whether the permit provisions have been fully implemented and how long they have been operational. Major installations often require two or more years to construct. Since the act has been in effect only since October 1972 , some facilities may not as yet be completed, even though there were no construction delays. Construction of many municipal plants has been delayed by the lack of Federal, State or local matching funds.

Important questions for a January 1, 1977 evaluation of progress may then relate to whether those holding permits are on schedule and if there have been waivers in the requirements.

For these permits which are fully implemented, the efficiency of operations and their strict enforcement constitute additional considerations.

\section{Marine Sanitation Devices}

Untreated sewage from concentrated boating use can create a pollution problem for shellfish waters equal to the untreated wastes of a small town. Pollutants introduced into waterways from commercial vessels and recreational boats are covered by the act under Section 312. EPA is required to promulgate performance standards for onboard marine sanitation devices (MSD), such as treatment equipment or holding tanks, to prevent the discharge of untreated or inadequately treated sewage. The standards are to reflect a consideration of the economic costs involved and the technology available.

Federal standards for MSDs (40 CFR 140) supersede state standards. The Coast Guard is charged with enforcement of the Federal regulations (33 CFR 159). Regulations require that by January 31, 1977 new vessels (those constructed after January 30, 1975) be equipped with MSDs which retain their sewage in a holding tank (type \#3 MSD) or discharge an effluent with either a fecal coliform count of less than 1,000 milliliters (type 非 MSD) or less than 200 per 100 milliliters (type 非 MSD). After January 30, 1980, any device installed in a new vessel must be either type 非 $(200 / 100 \mathrm{ml}$.) or 非 (no discharge).

For existing vessels (built before January 30, 1975), no device is required until January 30, 1980. However, if a type 1 . 1 MSD is installed before January 30, 1978, no new MSD will be required in 1980 . If a device is installed after January 30, 1978, a type 非 will be allowed but must be upgraded to either type 非 2 or $\|^{3}$ by 1980 , depending upon the waters in which the vessel operates. 
The act provides a procedure for states to petition EPA for the establishment of a "no discharge" area in some or all waters of the state (Section 312(f)(3)) to be enforced under state law. For example, "no discharge" status has been approved for two harbors in California, Lake George, New York, and Lake Champlain, Vermont. For approval of the petition, the state must have adequate pump-out and treatment facilities. The procedure has not yet been used specifically for the purpose of protecting shellfish waters.피

Once a petition is approved, boat owners must comply and may not discharge wastes overboard. Many boaters dislike this requirement because some would like to install an onboard treatment device (maceration/ chlorination) and discharge the treated wastes, thereby avoiding use of the pump-out system. This would be allowable under the act, but not if the state chooses to prohibit this with stricter state law.

In addition, EPA has the separate authority to completely prohibit discharge, by Federal regulation, upon the application by a state that the "protection and enhancement of the quality of specified waters.... requires such a prohibition" (Section 312(f)(4)). There is no requirement under this provision (unlike Section 312 (c)(3)) that the state have adequate pump-out and treatment facilities. There have been no petitions granted under this provision to date. $\underline{2}$

The Coast Guard does not board vessels specifically for the purpose of enforcing MSD regulations. Officers do, however, check for the existence of a certified MSS while inspecting pleasure craft for compliance with safety standards. $\underline{3}$

There has been opposition on the part of some pleasure boat owners to installation of holding tanks. Their complaints are as follows:

o They are expensive.

o One must queue up at a shore pump-out facility.

o One must pay a fee to the pump-out facility operator.

o In many cases the pumped-out wastes simply go through and inadequate municipal treatment system right back into the waters that the holding tank system was designed to protect.

State action in the past has typically been to close recreational areas to shellfishing during the recreational issue. This was found to be a problem in the case studies. The problem appears to be getting worse because of population increases along coastal waters, and because

$\underline{1} / \underline{2} / \underline{3}$ Conversation with Lieutenant Knuth, Environmental Protection Branch, U.S. Coast Guard, Washington, D.C. 
of an increasing interest in recreational boating. However, implementation of the current regulations should correct the problem of sewage discharge from watercraft.

It seems reasonable to assume that by January 30, 1980, implementation and enforcement of the EPA/Coast Guard regulations as recently established under Section 312 will go far toward correcting any pollution problems resulting from sewage discharges from watercraft. Should there be such pollution problems in shellfish growing areas, either in the interim or after full implementation in 1980, Section 312 also provides means to prohibit all waste discharges from watercraft. Availability of pumpout facilities should help correct much of the opposition to holding tanks. Local government could either provide the facilities or make the licensing of any marina fuel dock, yacht club or similar facility conditional upon the reasonable availability of pump-out facilities.

\section{Disposal of Dredging Spoil}

Through Section 404, the act seeks to control pollution associated with dredging and filling operations by requiring that a permit for disposal of dredged or fill material into navigable waters be obtained from the Army Corps of Engineers. If The Corps must apply EPA guidelines in issuing the permit, and any Corps permit is subject to a veto by EPA if the discharge of materials will have an "unacceptably adverse effect" on water supplies, shellfish beds or other fishery, wildlife, or recreational areas. Federal and state agencies concerned with the consequences of a given permit on fish and wildlife habitat are afforded the opportunity under the Fish and Wildlife Coordination Act to make their concerns known. 2 I

There are increasing and constant pressures on the environment from the efforts to develop water front property by dredging and filling. 3 / In the New York case study, (see Appendix A), reference is made to dredging and filling activity that destroyed or degraded over 1,100 acres of estuarine habitat over a seven-year period in the early $1960^{\prime}$ s in Suffolk County alone.

The intent of this provision in FWPCA is to ensure that no such activity is carried on without a permit, and that the permittjng process considers,

1/ See discussion on the history of Corps of Engineers' activity which follows the Marine Protection, Research, and Sanctuaries Act in Appendix B.

2/ See discussion of Fish and Wildlife Coordination Act, herein.

3/ Two court cases of importance clarified the reach of FWPCA on dredgeand-fill activities. Both are discussed in Appendix B. In U.S. V. Holland, 373 F. Supp. 665 (M.D. Fla. 1974), the court said that Corps jurisdiction under Section 404 extends to dredge-and-fill activity in waters irrespective of their navigability; in N.R.D.C. V. Callaway, 392 F. Supp. 685 (D.D.C. 1975) the court extended the jurisdiction to all waters of the United States, even wetlands above the high tide line. 
among other concerns, the effect of the activity on shellfish and marine ecosystems generally, and the persistence and permanence of the effects. If insufficient information exists to answer these points, this may be the basis for denial of a permit.

Implementation of Section 404 has been delayed by legal tests of its applicability to certain areas and activities. The extent of the Corps' jurisdiction under the act has only recently been settled and interim permit regulations have been issued.1/ Federal and state fishery agencies, the shellfish industry and the public should observe this program carefully to insure that the Corps and EPA are fully advised concerning shellfish resources.

\section{Toxic Discharges}

The possibility of a "no discharge" status also holds true for toxic pollutants and other hazardous polluting substance. EPA can prohibit the discharge of these substances where it is deemed necessary because of potential harm. As noted earlier in this report, adequate data has not always existed to provide a basis upon which EPA could make judgments concerning certain substances. In these instances EPA has had difficulty in regulating aggressively. EPA was sued by an environmental group to broaden its regulatory efforts on toxic substances. 2/ A settlement was reached by the parties under which EPA agreed to expand its 1ist of toxic pollutants and, in accordance with an agreed-upon timetable, to issue effluent limitations and guidelines, new source standards of performance, pretreatment standards, and to publish water quality criteria for toxic pollutants. As part of its effort in publishing water quality criteria, EPA will be conducting a three-year study on the effects of the pollutants, on the technical feasibility of control, and on economics of the control technology. The study is to be completed by 1979 .

Interviews with EPA Region II officials revealed a concern for toxic substances going into Raritan Bay, New Jersey from industrial dischargers. There are copper discharges in the industrial wastewater, but no effluent guidelines have been established for copper. One of the problems for these who set guidelines is that, as pointed out earlier in this report, toxicological evidence as to the body burden of molluscan shellfish is not available. In the Great South Bay case study (see Appendix A), it was reported that metal-plating wastewater containing toxic heavy metals was being discharged into the Patchogue River and on into Great South Bay.

\footnotetext{
1/ Corps of Engineers Interim Regulations Permits for Activities in Navigable Waters or Ocean Waters, 33 CFR 2091, 120 FR 40, \#144, July 25, 1975, pp. 31320-31344.

2/ Natural Resources Defense Council v. Train, 8 E.R.C. 2120 (D.D.C. 1976).
} 
No investigation was underway to determine the degree of this discharge or to evaluate its effect on the oyster beds of the Bay.

There are also problems for the estuarine habitat from toxic substances that are produced by industry for distribution into the marketplace. Insecticides, herbicides, and pesticides (discussed herein as part of the agricultural wastewater problem) are products that will eventually be washed into the rivers and to the sea. PCBs, a liquid used in transformers, accumulates in oysters and other aquatic organisms and can halt growth, alter the tissues of internal organs, and cause death. In the human body it is a suspected carcinogen PCBs in wastewater, as a manufacturing by-product, would be covered under FWPCA, and is indeed one of the toxic pollutants on EPA's list. Standards have been put forth by EPA I/ which would eliminate the discharge of PCBs in industrial wastewater. Toxic substances that industry proposes to manufacture and market will henceforth be subject to the new Toxic Substances Control Act, $\underline{2}$ and will go through a screening and testing procedure to determine at the outset whether there exists an unreasonable risk of harm to human health or to the natural environment.

For persistent toxic substances that have already found their way into the environment, information is needed to determine their location. The Virginia case study (Section 5 of Appendix A) tells of ongoing research on this matter by state agencies (e.g., in the Potomac River for mercury and the James River for Kepone), and by the Virginia Institute of Marine Science (dredging and resuspension studies).

The control of toxic substances is difficult to achieve because they are widely used and manufactured in large quantities. They enter the aquatic environment through multiple routes, as residuals from normal use, from accidents in the open environment, as incidental components of other wastes and as wastes from the manufacture of many chemical products.

Problems concerning toxic substances are accentuated by their persistence, bioaccumulative characteristics, the increasing numbers of compounds involved and metabolites produced in nature. There is a lack of knowledge concerning the general effects of specific compounds on mankind and nature.

Acceleration of research, monitoring, control through technology and regulation and in cleanup efforts, is needed to solve the toxic substances problems already on hand and to prevent the development of

I/ 41 Federal Register 30468, Ju1y 23, 1976
2/ P.L. 94-469, 15 U.S.C. 2601-2629 (1976). 
additional ones. Diligence in the administration of the efforts under FWPCA, the Toxic Substance Control Act and other Federal and state toxic substances statutes is essential.

\section{Municipal Sewage Treatment}

Publicly owned sewage treatment works (municipal treatment plants) are subject to the provisions of FWPCA, and their discharges must meet effluent guidelines established by EPA. These are, again, technologybased. To comply with the requirement for achievement of secondary treatment due by July 1, 1977), a municipal treatment works must meet the EPA guidelines shown in Table 11.

Using construction grant monies provided under FWPCA, municipalities are constructing sewage treatment plants, and there are success stories associated with that construction. For example, as reported in the Maryland case study, upgrading of a single sewage treatment plant resulted in the opening of 3,600 acres of shellfish waters in the lower Choptank River.

Table 11

EPA GUTDELINES FOR SECONDARY TREATMENT

\begin{tabular}{lll} 
& \multicolumn{2}{c}{$\begin{array}{c}\text { Concentration } \\
(\text { milligrams/liter })\end{array}$} \\
\cline { 2 - 3 } $\begin{array}{c}\text { Percentage } \\
\text { Removal }\end{array}$ & Monthly & Weekly \\
\hline
\end{tabular}

Biochemical Oxygen

Demand (5 day) 85

30

45

Suspended solids

85

30

45

Coliform bacteria

200

400

$\mathrm{pH}$ (acidity/alkalinity index): 6.0 to 9.0 
The availability of Federal construction grant monies to states was delayed, $1 /$ and in some cases state and local matching funds were also not immediately available. The construction program nationally is behind on a schedule that would allow for achieving the July 1, 1977 requirement that all municipal waste treatment works employ secondary treatment. As stated previously, EPA estimates that only 50 percent of the Nation's permitted municipal works will meet that requirement. $2 /$

Construction grants are available for collection systems as well as for treatment works. Many cities have combined sewers, so that updating treatment facilities alone would not solve their problems. However, the cost of replacing a combined sewer system with a separate one is not feasible for many cities.

This situation exists even though, under the act's grant provisions, the Federal Government will provide three dollars for every one local dollar. This reluctance is discussed in the Virginia and Maine case studies. There were two additional factors reported in Maine; construction of a new treatment plant was resisted because of aesthetic considerations, and because it was feared that increased treatment capacity would induce town growth. Finally, some communities simply do not and will not have the money to match against the Federal grant.

Disinfection of sewage effluent requires special attention. This practice is of major importance to the molluscan shellfish industry. It is intended to control coliforms, fecal coliforms and other pathogens which are the principal factor nationwide in the closing of shellfish beds. Unfortunately, chlorination, the principal disinfection method, has now been shown to cause adverse effects, including death in some cases, of living resources in the receiving water. Improved, fall-safe technology is badly needed and should receive priority in research. Special attention should also be given to the effects of massive freshwater discharges from major treatment plants on the natural salt and freshwater and temperature regimens of the estuary.

A related problem comes from an increase in nutrients delivered to receiving waters. This is a direct consequence of population increases and the stepped-up efforts in treatment works construction which has brought volumes of sewage formerly disposed of in septic fields to the waterfront sited sewage plants for treatment and discharge. Treatment of previously untreated wastes discharged to open waters reduces the biological oxygen demand in such waters and the quality is improved.

If Not all construction monies appropriated by the Congress to EPA were made available. As requested by the office of Management and Budget, EPA withheld $\$ 9$ billion in construction grant allotments. The U.S. supreme court, on February 18, 1975, ruled that these construction grant allotments must be passed on by EPA to the states in the full amount allotted by the Congress. Train v. City of New York, No. 73-1377 (U.S., February 18, 1975).

2) "Clean Water, report to Congress, 1975-76," U.S. Environmental Protection Agency, 1976. 
However, much of the original nutrient content of sewage remains in the discharge. These nutrients, basically nitrogen and phosphorus, when in excessive amounts can cause algal blooms leading to a reduction of dissolved oxygen under certain conditions. It is ironic that the program aimed at reducing pollution as a way of assuring a healthful shellfish industry may occasionally lead to conditions harmful to shellfish. Nutrients should be measured carefully so as to provide information for evaluating the future needs for tertiary treatment as more discharges are added to the system.

\section{Stormwater Runoff \\ a. Urban Runoff}

In setting out the effluent guidelines for achievement of secondary treatment, EPA made allowance for deviation from the guidelines for the impact of sudden stormwater flows on treatment works occurring through combined sewers. This point is central to an understanding of why many states will be unable to meet the 1983 goal. If the city has a separate storm sewer system, most of the storm runoff passes directly to the stream, carrying its load of air pollutants gathered by the falling rain, sediments and surface pollutants (e.g., heavy metals, insecticides, organic debris, coliform bacteria, and others).

If there is a combined sewer system, the enormous quantity of water resulting from the storm causes an overload of the municipal treatment works, with the result that overflow pipes carry the excess, mixed with raw sewage in some cases, into the receiving body of water. This stormwater problem was expressed to the study team in every state visited. It was identified as a principal reason for shellfish beds being closed.

The following is taken from the State of Washington case study (see Appendix A) :

\footnotetext{
"High stream runoff and combined wastewater/sewage collection systems result in poorly treated discharges or even raw discharges bypassing the treatment facilities altogether. Elevated coliform counts during these periods result in shellfish area closures..."
} 
One conceptual solution is to require that stormwater be collected and discharged into a treatment works designed and constructed to handle the total flow. Such a system nationwide could cost as much as \$235 billion, almost twice the amount estimated by the states for building a system to handle day-to-day municipal sewage loads, $1 /$ and almost 13 times the amount already provided by Congress. 2/ The survey did not determine the portion of these estimated costs which were related to stormwater discharges in she11fish growing waters.

Separation of combined sewers would accomplish much, as would some form of retention to permit minimal treatment of the initial stormwater flow which probably contains the bulk of the contaminant load. Improved sanitation on city streets and parking lots would reduce the extent of runoff contaminants in many areas.

Stormwater runoff, especially from urban areas and certain agricultural activities, contributes substantially to water pollution problems affecting shellfish resources. Such interests contend that this is the major source of pollution and that point source clean up will still not permit attainment of the water quality levels necessary for shellfish harvest because of the runoff problem and wastes from natural wild populations of waterfowl or other animals. Undoubtedly, non-point source runoff is a major problem in many areas. However, the true impact of runoff on water quality clearly cannot be determined for a given area until all the controllable sources are brought under effective control. There is a tendency to blame all pollution not obviously traceable to a point source on non-point sources. However, in some cases this may in reality include impacts from malfunction or incompetent operation of sewage treatment plants, surreptitious pumping of holding tanks, septic tank seepage, or other violations of permits or standards.

\section{b. Agricultural Wastes}

Agricultural wastes are a major source of pollutants, many of which reach the waterways as stormwater runoff from agricultural areas. Major problems are animal wastes, silt and sediments, nutrients, fertilizers, pesticides, including both herbicides and insecticides, and other agricultural chemicals.

1/ "Needs Survey," reported in "National Water Quality Inventory; 1975 Report to Congress," Washington, D.C., 1975, Environmenta1 Protection Agency, 1974.

2/ In a July 31, 1975 letter to the Office of Management and Budget, EPA suggested the need for additional Federal funding of $\$ 42$ billion, at $\$ 7$ billion annually during fiscal years 1977 through 1982 .

(Comptroller General of the United States, "Implementing the National Water Pollution Control Permit Program," February 9, 1976, p. 35.) 
Virginia has made progress in the handling of animal wastes, and reports that 80,000 acres of shel1fish beds were opened up during 1972 , 1973, and 1974, as a result of the Act.1/ Another example that shows how agricultural wastes are being dealt with under the Act is found in the Great South Bay case study (see Appendix A). Sixteen duck farms on Long Island have been issued NPDES permits. The initial permits did not solve the wastewater problem, and 85 percent of the shellfish waters had to be closed. In the second stage, upgraded treatment has been required, including the following:

o Better wastewater containment.

o Reduction of influent flow.

- Increased disinfection reliability through the use of dual chlorinators with automatic switchovers, and an automatic alarm system to warn of low chlorine levels.

Any agricultural runoff from cultivated lands emanating from precipitation may cause nutrient, chemical and siltation problems in the aquatic system. Increased land clearing and draining, accelerating use of chemicals and fertilizers, and similar intensification of land use may impact on shellfish waters, where effective controls are not available.

An especially difficult problem is how to deal with agricultural runoff that contains pesticides and herbicides. As discussed earlier in this section, FWPCA can control the discharge of these substances at the point of manufacture through regulation of the discharge of industrial wastewaters containing toxic pollutants. The Toxic Substance Act, $\underline{2}$ I previously discussed, and the Federal Insecticide, Fungicide, and Rodenticide Act $\underline{3}$ (FIFRA)--as amended by the Federal Environmental Pesticide Control Act 4 / (FEPCA)--seek to discover, prior to marketing, what the effects on the environment might be, and then to either prohibit any marketing of the product or, where appropriate in the case of an herbicide or pesticide, to license the individual who will apply the product, and to restrict the purpose, manner, and geographical area of its application.

Solutions to the problems of non-point source pollution are largely dependent on the effectiveness of areawide basin planning.

1/ See Virginia case study, Appendix A.

2/ P.L. 94-469, 15 U.S.C. 2601-2629 (1976).

3/ 7 U.S.C. 135, et seq.

4/ P.L. 92-516 (1972). 


\section{Areawide Planning}

The Act provides for regional, basin, and areawide wastewater treatment planning by the states for a rational approach to solving water quality problems (Sections 208 and 209). Through such planning the Act seeks to avoid haphazard construction of treatment works and to provide a means of dealing with the more difficult sources of pollution (e.g., urban runoff and agricultural runoff). With the initial emphasis on implementation of the discharge permit programs and on construction of municipal treatment works, only recently has emphasis been placed on areawide planning. Substantial planning of areawide studies is now underway with most of the initial plans due to be received by EPA in 1978. It seems premature at this time to draw any conclusions as to how effective that program will be. The need for areawide planning was noticed particularly in the Apalachicola Bay case study where construction grant money for a new treatment works has been approved, but areawide planning which is underway, has not advanced enough to deal with the areawide runoff problem. When asked about basinwide planning to alleviate water pollution of Apalachicola Bay's shellfish beds, a Federal official stated that other interests such as agriculture, navigation, and construction would present formidable opposition to a comprehensive plan.

It appears that the "Level $B$ " river basin planning efforts under the Water Resources Planning Act, as required by Section 209 of the Federal Water Pollution Control Act Amendment of 1972, has not been adequately implemented at this time.

Both the areawide and "Level B" planning efforts could assist greatly in addressing difficult pollution problems including those of non-point source pollution.

\section{P.L. 92-500 Summary}

Given time, sufficient matching funds, strict adherence to compliance schedules, and enforcement, the present NPDES program can help to restore and protect shellfish growing area water quality.

The municipal waste treatment program has lagged substantially because Federal construction funds were impounded and state or local matching funds were not always available. It is imperative that the municipal treatment works construction program be accelerated. Continuous monitoring and evaluation of the program will be essential to determine its effectiveness.

Urban and agricultural runoff are probably the most serious pollution sources for which adequate technology and effective program implementation are the least advanced. Implementation of the areawide planning program and the "Level B" river basin plans can assist in correcting these problems. 
Effective protection for shellfish resources and their habitats from placement of dredged and fill material can now be achieved through implementation of the dredged and fill material placement program as defined in the Corps of Engineers' regulations.

Attainment of the high water quality specified for shellfish harvest areas under the water quality standards is essentially dependent on full and effective implementation and enforcement of the water quality standards, the NPDES program, the marine sanitation devices program, control of dredged and fill material placement, and development and application of effective measures for.control of non-point source pollution.

Al1 aspects of the P.L. 92-500 programs which involved issuance of permits, or establishment of water quality standards, would be more effective in protecting shellfish and other living aquatic resources if $\mathrm{F} \& \mathrm{~W}$ agencies could provide EPA and the State pollution control agencies with prompt and pertinent consultations under the Fish and Wildlife Coordination Act and other resource management authorities.

\section{B. River and Harbor Act of $18991 /$}

This law gave to the U.S. Army responsibility for regulating the Nation's navigable waterways. The Act forbids watercourse obstruction except under a permit issued by an authorized official of the Army Corps of Engineers. The definition of "navigable" waterways is a traditiona1 one consistent with the Corps responsibility to keep the navigable waters and their tributaries free of impediments. Thus, the construction of dams and dikes or other alterations may be undertaken only if a permit is issued by the Corps of Engineers. Consistent with the Fish and Wildlife Coordination Act, 29 Federal and State agencies with responsibilities for fish and wildlife concerns are afforded the opportunity to comment on the proposed permit's possible consequences. Again, there are difficulties in achieving this interaction because of staffing limitation within the agencies. This point is developed in the discussion of the Fish and Wildlife Coordination Act.

To be effective, this permit system must be implemented. In the 1971 Puget Sound hearings, Congress learned that an estimated 80 percent of the structures in place were there without a permit--some 50,000 illegal structures in the Sound.

C. Marine Protection, Research, and Sanctuaries Act of 1972, as amended 3 /

This is a companion law to the Federal Water Pollution Control Act Amendments of 1972 (FWPCA). 4 / Congress was concerned that stringent controls on domestic discharge under FWPCA would encourage the dumping of materials into the ocean beyond the 3-mile limit. Title I, often

1/ 30 Stat. 1151-1154, 33 U.S.C. 401 et seq.

2/ P.L. 85-624, 16 U.S.C. 661-664 (discussed herein).

3/ P.L. 92-532, 33 U.S.C. 1401 et seq, 1976 Supp.

4/ P.L. 92-500, 33 U.S.C. 1251 et seq. 
referred to as the Ocean Dumping Act, prohibits or strictly limits the disposal into the ocean of those materials that would adversely affect:

o Human health, welfare, amenities.

o The marine environment.

- Ecological systems.

- Economic potentialities.

This Act is the enabling domestic legislation for fulfilling U.S. responsibilities under the International Ocean Dumping Convention.

Jurisdiction under the Act is divided between the Army Corps of Engineers and EPA. The Corps has permit jurisdiction for the transportation and dumping of material dredged or excavated from navigable waters of the United States. I/ A permit approved by the Corps is subject to the veto of EPA if the Administrator finds that the material will result in an "unacceptable adverse effect on municipal water supplied, shellfish beds and fishery areas (including spawning and breeding areas), wildlife, or recreational areas." 2 /

EPA has responsibility for establishing criteria for ocean dumping and issuing permits pursuant to those criteria for materials other than dredged spoil. In making a decision to issue a permit, EPA is required to consider the following:

o The need for the dumping.

o The effect on health, welfare, aesthetics, and recreation.

o The effect on fisheries resources, plankton, fish, shellfish wildlife, shorelines, and beaches.

o The effect on marine ecosystems, particularly the concentration and dispersion of the dumped materials and potential change in marine diversity, productivity, and stability.

o Such other criteria as may be suggested by Federal, State, and local agencies, and by the general public.

I/ Dredged materials constitute about 90 percent of the materials dumped in coastal waters. The disposal of dredge spoils is of particular concern because aquatic sediments may contain levels of heavy metals, chlorinated hydrocarbons, and other toxic materials several times those found in the overlying water column. Ocean dumping resuspends these elements and thus threatens the surrounding marine ecosystem "Environmental Quality--The Seventh Annual Report of the Council on Environmental Quality," Council on Environmental Quality, Washington, D.C. pp. 25, 279-280, September 1976.

2/ P.L. 92-500, Section 404 (c). 
The U.S. Coast Guard is the designated agency for carrying out surveillance and compliance monitoring. Violations of permits and illegal dumping are subject to civil and criminal penalties.

The Act also provides for the establishment of marine sanctuaries and for research into the causes and effects of marine pollution.

EPA has published regulations that contain the technical criteria used in the evaluation of a permit application (40 CFR 227). These regulations contain, for example, the maximum allowable concentration of toxic substances and apply to the disposal of all materials. If Not all materials currently being dumped meet these criteria. These materials are being dumped pursuant to interim permits and consist of municipal sewage sludge and industrial wastes.

Under EPA's interim permit system, dumpers are required to find and implement alternatives as soon as possible. No new interim permits will be issued after April 23, 1978, other than to municipal and industrial dischargers already dumping into the ocean under interim permits. A11 dumping pursuant to interim permits must terminate prior to 1981.

Large amounts of sludge that must be disposed of are expected to be generated by the upgrading and new construction of municipal treatment works. According to EPA, the volume of sludge produced in 1976 will double by 1981.21. EPA was concerned about the effects of dumping increased volumes of sludge at one of the existing dump sites in the New York Bight, and undertook an investigation of an alternative site. Approximately four million cubic meters ( 5.2 million cubic yards) of sewage sludge are dumped in the Bight annually. However, after study of the matter, EPA decided not to use an alternative site. EPA now plans to phase out the dumping of sewage sludge provided that environmentally sound, and technically and economically viable land-based disposal methods are found. EPA has funded a study of the following land-based alternatives to the ocean disposal of sludge:

o Incineration.

o Pyrolysis.

o Land application.

o Sale as a soil conditioner or fertilizer.

I/ "Final Revision of Regulations and Criteria," U.S. Environmental Protection Agency, Federal Register, Vol. 42, p. 2462, January 11, 1977.

2/ "Environmental Impact Statement on the Ocean Dumping of Sewage Sludge in the New York Bight," U.S. Environmental Protection Agency, February 1976. 
EPA is interested in land-based alternatives for two reasons: (1) The concentrations of heavy metals, organic matter, coliforms, chlorinated hydrocarbons, and nutrients can cause serious problems for marine life in the dump site area, and (2) much of the sludge represents a valuable resource if properly used. EPA's study of alternatives also included the recommendation that the environmental impact of the Corps' dredge material dumping operation be studied, as well as disposal options to eliminate ocean dumping.

Communities in the New York metropolitan area, Philadelphia, and Camden, New Jersey, have been dumping sewage sludge into the ocean for several years and now dump pursuant to interim permits. This dumping is scheduled to cease prior to 1981. There is reason to believe that this dumping has adversely affected marine shellfish resources.

The New Jersey case study (see Appendix A) refers to a recent plankton bloom off the New Jersey coast that resulted in the death of large numbers of finfish and surf clams. Part of the problem was traced to abundant nutrients from ocean dumping. In addition, there is concern that some sewage sludge is being dumped short of the designated area by individuals not going all the way out to the demarcated zone, and that these vessels are evading Coast Guard surveillance. In January 1977 , Camden received an EPA grant of $\$ 1.2$ million to build a sludge composting plant which will allow the city to stop all ocean dumping of its sewage sludge within 6 months.

In summary, EPA expects the combination of strict uniform criteria for wastes and the termination by 1981 of interim permits will drastically curtail ocean dumping and the resultant degradation of the marine environment.1/ Acceleration of the research to find land-based alternatives to ocean dumping could reduce this threat to shell fisheries at an earlier time.

\section{Fish and Wildlife Coordination Act of 1958는}

This single Act, outside of a fully implemented Federal Water Pollution Control Act, has the greatest potential for ensuring a healthful molluscan shellfish environment.

The Act requires every public agency performing or permitting any water diversion, impoundment, dredging, filling, or other watercourse alteration to consult with the Fish and Wildlife Service, the National Marine Fisheries Service, $\underline{3 /}$ and the appropriate state wildlife agency to determine the impacts of the proposed project on fish and wildlife. Recommendations can be made for protecting, conserving, and

1/ "Transition papers to Incoming Carter Administration on Areas of Agency Jurisdiction," U.S. Environmental Protection Agency, January 1977.

2/ P.L. 85-624, 16 U.S.C. 661-664.

3// Reorganization Plan No. IV, 1970. 
enhancing wildlife resources in the project plans. The agency may justify cancelling the project or denying a permit on the basis of fish and wildlife concerns, I/ particularly when recommended by state or local agencies.

The Act applies to the planning and construction of dams and reservoirs, hydroelectric power plants, ship channels, and other navigation projects, dikes, levees and other water supply or flood control projects by public agencies. The Act also applies to permits issued by public agencies under the FWPCA (EPA or state issued NPDES discharge permits and Section 4.04 dredge spoil disposal permits), the River and Harbor Act of 1899 (Corps of Engineers' permits for dredging, pier or other construction in a navigable waterway), Marine Protection, Research, and Sanctuaries Act (ocean dumping permits issued by the Corps for dredged materials, and ocean dumping permits issued by EPA for all other materials), the Deepwater Port Act $2 /$ (construction and operating licenses), and the Outer Continental Shelf Lands Act $3 /$ (offshore drilling leases).

The Fish and Wildlife Coordination Act provides a mechanism for the National Marine Fisheries Service, the Fish and Wildlife Service, and the concerned state fish and game agencies to furnish the permitting and planning agencies with expert consultation services to insure that the public's interest in its natural resources are adequately protected whenever discharge or construction permits are being considered or construction projects are being planned.

Fish and Wildlife reports are filed by the NMFS in response to requests for consultation from the permitting and planning agencies. The NMFS in these reports:

o Describes the project proposal.

o Analyzes the proposed physical changes to the environment.

o Identifies the potential impacts on living resources.

o Recommends measures to prevent or minimize damages and to mitigate unavoidable damages, and can include recommendations to deny issuance of the permit in extreme circumstances.

In the case of waste discharge permits, NPDES, or construction permits, damage prevention measures may include consideration of the amount, kind, condition and schedule of discharges; i.e., sewage, pathogens and coliforms, chemicals, nutrients, silt, oil, fresh water,

I/ This aspect of the Act was confirmed in Zabe1 v. Tabb. $403 \mathrm{~F} .2 \mathrm{~d}$. 199 (1970). (This case is discussed in Appendix B.)

2/ P.L. 93-627, 33 U.S.C. 1501 et seq., discussed herein.

3/ P.L. 83-212, 43 U.S.C. 1331-1343 (1970). 
heat, and other materials; and disinfection methods. Also considered are the location of the discharge structure in relation to shellfish beds or other resources, construction methods and seasonal scheduling, spoil placement, and other factors which could have an impact on the shellfish resources, including their survival, productivity, and harvestability.

The NMFS recommendations to protect shellfish and other resources may include adjustments in quantity, kind or condition of material proposed to be discharged, disinfection techniques, changes in the location of the discharge or of a spoil placement site, the construction methods or season of performance.

The NMFS has found it necessary, because of limitations of funds and manpower, to restrict its activities to projects which would cause the most severe and irreversible damages to the habitats of marine fishery resources. In many cases priorities have been further adjusted by the logistics of project location in relation to NMFS field offices.

The legislative history of the Act recognized that these activites can have severe effects on fish and wildlife and on their habitat. The Corps of Engineers alone conducts hundreds of maintenance dredging operations each year and must dispose of the dredge materials. The Corps also constructs and maintains ship channels such as the $\$ 350$ million Mississippi-Gulf Outlet canal discussed in Appendix A, and massive public works programs involving dams, reservoirs, and many other projects. The Bureau of Reclamation also has large scale water development projects in the Western States, many of which may severely impact estuaries with molluscan shellfish resources.

The total number of projects and permitting activities of all public agencies is impressive. In fiscal year 1975, the National Marine Fisheries Service received approximately 400 notices of proposed Federal projects, 11,000 notices of proposed dredge-and-fill and construction permits from the Corps of Engineers, and over 25,000 notices of proposed NPDES permits from EPA and state officials (See Table 12). These large numbers of requests for comments in some instances, have overwhelmed the limited staff of the National Marine Fisheries Service and some State agencies. The Fish and Wildlife Service, however, has stated that their efforts to protect shellfish resources have been effective relative to their responsibilities under the Section 10 and 404 permit programs, particularly in the last 5 years. However, the Fish and Wildlife Service indicates that they too lack the resources to adequately handle the large number of NPDES permit notices which they receive. 
NATIONAL MARINE FISHERIES SERVICE

ENVIRONMENTAL ASSESSMENT DIVISION CASELOAD RESPONSES

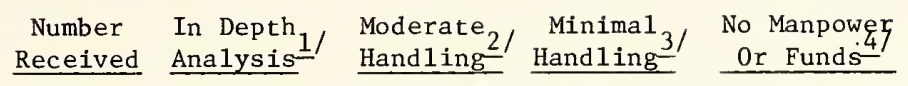

FY 1973

Section 10 and 404 permits

NPDES permits

Other permits

NRC \& FPC Licenses

Federal projects

FY 1974

Section 10 and 404 permits

NPDES permits

Other permits

NRC \& FPC Licenses

Federal projects

FY 1975

Section 10 and 404 permits

NPDES permits

Other permits

NRC \& FPC Licenses

Federa1 projects

FY 1976

Section 10 and 404 permits

NPDES permits

Other permits

NRC \& FPC Licenses

Federa1 projects

TOTALS

Section 10 and 404 permits

NPDES permits

Other permits

NRC \& FPC Licenses

Federal projects
8,076
2,758
132
7
456

$\begin{array}{rr}11,069 & 824 \\ 30,071 & 130 \\ 159 & 82 \\ 31 & 26 \\ 386 & 100\end{array}$

11,548

25,581

223

20

417
14,624
9,697 ㄴ
337
15
332

605
13
62
13
220

3,591

952

91

7

96

3,896
189
57
5
175

3,186

$-7$

3,163

29,752

$--$

$--$

105

$\begin{array}{rr}4,851 & 2,501 \\ 3 & 24,613 \\ 35 & 35 \\ -- & -- \\ 11 & 90\end{array}$

4,110

493

103

4

50

5,492
--
54
--

4,339

9,192

89

112

$\begin{array}{rr}45,320 & 2,425 \\ 68,107 & 161 \\ 851 & 268 \\ 73 & 56 \\ 1,591 & 539\end{array}$
14,420
1,669
335
17
457
16,962
3
111
$--$

11,510

66,274

137

$288 \quad 307$

Adapted from information received from the Environmental Assessment Division.

1/ An "in-depth analysis" involves: thorough knowledge of the biotic system affected, which may be gained through site visits and literature searches; study and understanding of the design and effects of the proposed alteration; coordination with all concerned states, Federal agencies, and others; and filing of a written analysis. Appearances at public hearings and in court may be required.

2/ "Moderate handling" requires lesser effort than "in-depth analysis", but still requires first-hand knowledge of the area affected and of the proposed alteration. Typically, the size of the project is smaller, design specifications more routine, and coordination is required with fewer other parties. Public hearings and court appearances are not required.

3/ This portion of the workload is treated in one of several ways: screened out as not requiring response; given cursory review and responded to with a form letter; or, no action may be taken. The number of kinds of workload items which are handled in these ways varies among regions, depending on such factors as the numbers of states and Federal agencies in the region, variation in level of cooperation among interested parties, and social and economic importance of fisheries resources.

$4 /$ NMFS responds with a letter to issuing agency advising of "no manpower or funds" available for review. Cases so treated are not viewed as having been adequately screened.

5/ Does not include FY 1976 (T) period (7/76-9/76).

6/ This drop from previous years may reflect a failure to receive all public notices. 
In reviewing and analyzing permit requests and Federal projects, the National Marine Fisheries Service has consistently been concerned with near shore and estuarine waters and their attendant shellfish resources. Laboratories staffed by knowledgeable scientists located on both coasts and the Gulf of Mexico are providing NMFS habitat protection biologists with the information necessary for making critical management decisions. The National Marine Fisheries Service, based on their acknowledged expertise in the estuarine and marine field, is not satisfied that the shellfish resources, their habitat and their future are being adequately safeguarded. It should be stated that not all of the permits would be of major importance to fish and wildlife concerns. However, the task of screening 36,000 total requests requires the attention of people who are knowledgeable and can recognize those permits or projects that will require active involvement because the projects present a real risk to fish and wildlife habitat. Without adequate staff for these agencies, much of the effectiveness of the Fish and Wildlife Coordination Act is lost and there are no mechanisms which compensate for this lack of performance. The Act recognizes that the permitting agencies may lack the competence to evaluate the impacts of their proposals on the public's natural resources. Thus, the effectiveness of the permitting programs as environmental and natural resources protection measures is compromised by the lack of input by the resource management agencies.

In a letter from two members of the U.S. House of Representatives to the Secretary of Commerce, $1 /$ the following observation was made:

... we think that you have an obligation under the Coordination Act to, at least, inform in writing EPA, the Corps of Engineers, and other permitting and licensing agencies, and, most importantly the public that a particular permit application will have no significant effect on fish, shellfish and wildlife resources, or that you lack the funds and manpower to comment thereon.2

The Secretary of Commerce, on behalf of the National Marine Fisheries Service, replied with the following assurances: 3 /

\footnotetext{
"We intend to meet our obligations and responsibilities under the Fish and Wildlife Coordination Act to the best of our capability... We feel that the public is entitled to the best effort that we can make on each application within the framework of our funds and manpower."
}

1/ Letter to Secretary of Commerce from the Chairman of the Subcommittee on Fisheries and Wildlife Conservation (Committee on Merchant Marine and Fisheries) and the Chairman of the Subcommittee on Conservation and Natural Resources (Committee on Government Operations), U.S. House of Representatives, June 6, 1973.

2/ Ibid., p. 2 .

3/ Letter to the Chairman, Subcommittee on Conservation and Natural Resources, Committee on Government Operations, U.S. House of Representatives from the Secretary of Commerce(Acting), July 14, 1973. 
As noted in Table 12, the National Marine Fisheries Service has been able to provide a "sufficient response" or an "in depth response" in only a small fraction of the total projects it is asked to review. The Regional Directors of the National Marine Fisheries Service have been instructed to respond to every EPA notice of permit action and, where appropriate, to issue a standard letter stating that the NMFS is unable to provide review because of lack of funds or manpower.1/

In the Apalachicola Bay case study, staffing limitations were noted at the Habitat Protection Branch of National Marine Fisheries Service in Panama City, Florida. At that facility, hundreds of requests are received each month seeking their review and comment on marine resource impacts and the potential habitat losses associated with proposed projects. Only the very major projects receive attention. NPDES requests receive no substantive review.

On a positive note, it was observed in several of the case studies that where comment is offered, it is considered. In Great South Bay, Long Island, New York, a proposed sewage pipeline that will cross under the Bay has been opposed by National Marine Fisheries Service because shellfish beds may be disrupted by the resulting siltation, possible reduction in streamflows, and changes in salinity. The New York State Department of Environmental Conservation notes that the Corps is seeking comment from state and Federal agencies as to its projects. $2 / \mathrm{A}$ cooperative attitude on the part of the Corps in regard to minimizing environmental harm was noted in the State of Washington case study. One final cbservation on this point. In Apalachicola Bay, the Corps makes an effort to bypass shellfish beds that are "flagged" or staked out by the watermen. Where there is no alternative to disrupting a given shellfish bed, the State of Florida has, on occasion, relayed the shellfish to new sites prior to the dredging operation. This is a remarkably hopeful sign of cooperation between Federal, state, and local institutions, and is an encouraging indicator of what can be accomplished by communication and cooperation.

Adequate corrective action cannot be taken on behalf of fish and wildlife, however, without sufficient numbers of trained personnel to monitor and make enlightened recommendations that will assure viability of the resource and minimize the risk of harm.

1/ Letter to National Marine Fisheries Service Regional Directors from the Director, National Marine Fisheries Service, February 12, 1974 .

2/ See New York case study, Appendix A. 
It is clear the FWCA provides an authority for the Federal fishery agencies (National Marine Fisheries Service and the U.S. Fish and Wildlife Service) and the state fishery agencies to participate in permitting and planning activities of the Federal construction agencies and therefore ensure that the public interest in its fish and wildlife resources is adequately considered in the decision-making processes. However, it is also clear that because of the lack of funds and manpower, the Federal fishery agencies have been unable to participate to an adequate degree and provide the permitting agencies with the expert consultation and advice concerning shellfish and other fish and wildlife resources in the activities those agencies conduct. A substantial number of the 68,107 public notices for NPDES permits (See Table 12) received by the NMFS during 1973-76, were in estuarine and coastal water areas where shellfish resources could have been, or undoubtedly were, involved but where this was undetermined. Obviously in most of those cases the permitting agencies were compelled to make their decisions without benefit of the resource management expertise of the Federal Government as housed in the fishery agencies, and specifically without benefit of the NMFS expertise concerning potential impacts on shellfish and other marine fishery resources. Therefore, the execution of the NPDES and other permitting programs may have been less effective in protection of shellfish and other resources than it would have been had the fishery agencies been funded and staffed to carry out the resource protection and management responsibilities given them by the Congress in the FWCA. This problem is in urgent need of resolution.

The Secretary of Commerce in a report, "A Marine Fisheries Program for the Nation, 1/ has recommended that the Fish and Wildlife Coordination Act be strengthened through amendments. A summary of potential amendments is set out in Appendix B.ㄱ/ These amendments would underscore and further clarify the consultation role of the National Marine Fisheries Service. Most importantly, the proposed amendments would allow for the transfer of funds from Federal construction and licensing agencies to fish and wildlife agencies so that these agencies will have the fiscal resources to carry out the purpose of the Act.

1/ "A Marine Fisheries Program for the Nation," U.S. Department of Commerce, July 1976.

2/ See Appendix B, Fish and Wildlife Coordination Act of 1958 (Comment section). 
E. Coasta1 Zone Management Act of $1972^{1 /}$ the Amendments of $1976^{2 /}$

The land at the water's edge unquestionably belongs to the individual states and to the people. $3 /$ This is firmly established in the Nation's laws and traditions. Thus, when Congress saw a need to protect, conserve, and restore the Nation's coastal zone, it passed legislation that would encourage the individual coastal and Great Lakes states to take on the task. The Coastal Zone Management Act provides money to assist the state's planning process and to administer the plan once it is approved.

The Federal role is to establish guidelines for the planning process and to coordinate the activities of Federal agencies in the coastal zone with the state plan. The law effectively makes a pledge to the states that once a state plan is approved, Federal activities in the coastal zone will be consistent with the provisions of the plan, except under conditions of overriding concern.

The Coastal Zone Management Act of 1972 contains a provision with special potential for the protection and restoration of shellfish resources and their habitat as well as other aquatic life.

Section 305 of the Act requires that each state make "an inventory and designation of areas of particular concern within the coastal zone." Section 306 requires that provisions be made for "procedures whereby specific areas may be designated for the purposes of preserving or restoring them for their conservation, recreational, ecological, or aesthetic values."

CZM regulations of 15 C.F.R. 923.13(b) require that the states provide policies or actions to manage the Geographic Areas of Particular Concern, once the areas have been designated.

Under the provisions of these sections of the Act, all major shellfish areas should be inventoried by the state and considered for designation as Geographic Areas of Particular Concern. If designated the states are responsible for policies and actions to protect them from competing uses and to restore their values.

The State Coastal Zone Plans should, of course, recognize the complexity and interdependence of all components of the ecological system of an estuary such as food web relationships, life history stages, and the detailed functions of physical and chemical elements of the system.

1/ P.L. 92-583, 16 U.S.C. 1451 et seq.

2/ P.L. 94-370 (1976).

$\underline{3} /$ The seabed also, out to a distance of 3 miles (three "leagues" for a few Gulf Coast States). See Discussion of Submerged Lands Act. 
Delineations of only limited geographic sites within an estuary, without regard to the complexity and interaction of the components within the estuarine system, may not provide adequate protection for a specific resource.

The State Coastal Zone Management agencies should be adequately informed concerning shellfish resource areas if they have consulted with State and Federal F\&W agencies to secure their views. In addition, in the State CZM Public Hearing Process, the shellfish industry and the public should inform the CZM agencies of the location, extent, threats, problems, needs, and opportunities affecting all shellfish grounds. Therefore, under the existing procedures the CZM plans of the State should contain the necessary provisions for designation, protection, and restoration of all shellfish resources areas.

Indications are that this may not be the case in all States. Verbal reports indicate that some States may not be doing an adequate job in inventorying and designating shellfish areas or other areas of major ecological concern. The State and Federal fishery agencies, the fishing industry, and the public, in general, should participate fully in all pertinent State Coastal Zone Management activities to insure that shellfish areas are adequately reported in the State inventories of areas of particular concern, and that they be designated for protection and restoration.

The Office of Coastal Zone Management should insure that all States are adequately complying with the requirements of Section 305(b)(3), 306 (c) (9), of the Act during the planning process and that all shellfish grounds are included in the GAPC inventories.

Before any States Coastal Zone Management Plan is submitted to the Secretary of Commerce for approval, the Office of Coastal Zone Management should assure that this activity has been fully dealt with in that plan and that adequate policies and actions are specified for protection of "Geographic Areas of Particular Concern."

The Coastal Zone Amendments of 1976 were passed to deal with the many conflicts of use in the estuaries and coastal areas. Congress recognized the inevitability of coastal energy-related activity and sought to provide funds to study, plan for, manage, and control the related impacts. Energy facilities foreseen by the amendments include the following:

- Electric power generating plants.

o Petroleum refineries.

o Gasification plants.

o Nuclear fuel facilities.

- $0 i 1$ and gas facilities.

- Petroleum transfer facilities. 
The amendments establish a Coastal Energy Facility Impact Fund which, in addition to supporting the planning function, may be used to "reduce, ameliorate, or compensate" for negative impacts.

As of this writing, only the State of Washington has an approved coastal plan. It will probably be several years before an accurate measurement can be taken of the degree to which planning under the Coastal Zone Management Act is beneficial to the estuary.

The Coastal Zone Management Act focuses on requiring each State to plan for its own needs. It is not necessarily true that a series of approved state plans will represent the best plan for the region. There is no provision in the Act to coordinate interstate river basin planning for coastal states whose estuaries are fed by interstate rivers.

F. The Submerged Lands Act ${ }^{1 /}$ and the Outer Continental Shelf Lands Act-

A Supreme Court decision (1947) held that the Federal Government rather than the states owned the seabed adjacent to the states' coastlines. $3 /$ The Submerged Lands Act was passed in 1953, conveying to the states that portion of the seabed lying seaward of their coast to a distance of 3 miles. Ownership and control of the seabed from that point seaward was to remain with the Federal Government. The Outer Continental Shelf Lands Act was subsequently passed to deal with the leasing and developing of the Federally-owned submerged lands.

The Secretary of the Interior conducts the leasing of the seabed on behalf of the Federal Government. The Secretary publishes regulations that must be drafted to prevent the waste of, and provide for the conservation of, natural resources (the definition includes fish, shellfish, and other marine life). The Secretary also drafts the individual leases. Consistent with the provisions of the National Environmental Policy Act, the Secretary must take environmental concerns into consideration when drafting a given lease. Furthermore, the Secretary may suspend operations under existing leases when it is determined that the risk to the marine environment outweighs immediate national interests in exploring and drilling for oil and gas.니

1/ P.L. 83-31, 43 U.S.C. 1301-1315 (1970).

2/ P.L. 83-212, 43 U.S.C. 1331-1343 (1970).

$3 /$ United States v. California, 332 U.S. 19 (1947).

4/ Gulf Oil Corporation v. Morton, 493 F, 2d 141 (1947). 
Because leasing for offshore drilling is a major Federal activity affecting the environment, an environmental impact statement (EIS) is required.1/ This allows for a review of the likelihood and degree of possible negative consequences for the marine environment. One problem with the EIS process relates to the geographical size of the leased areas. These areas have been so large that fish and wildlife review agencies have had difficulty particularizing their concerns regarding a specific organism at a specific location.

There is evidence of Federal and state cooperation in the program. The Secretary has entered into cooperation agreements with several coastal states $2 /$ where existing state regulations for exploratory drilling have been adopted as the Secretary's regulations. $3 /$

Statistics released by the Department of the Interior show a doubling of offshore leases between 1973 and 1974, and a corresponding doubling of the acreage leased. This, of course, reflects activities at the Federal level following the 1973 Arab oil boycott. Even considering this increased activity, the potential for more is great: Only 4.5 percent of the outer continental shelf of the contiguous states is under lease. 4 /

This potential does not look promising for marine life that might be harmed by both oil spills from the drilling operations and by related activities closer to shore (e.g., pipelines, refineries, etc.).

I/ National Environmental Policy Act, P.L. 91-190, 42 U.S.C. 4321-4347, (1970).

2/ These states are Georgia, Florida, Alabama, Louisiana, Texas, and California.

3/ "Outer Continental Shelf Statistics," U.S. Department of the Interior, June 1976.

4/ "Outer Continental Shelf Statistics," U.S. Department of the Interior June 1976. Total U.S. outer continental shelf is 560 million acres; contiguous U.S. continental shelf area is 186 million acres. 
G. Deepwater Port Act of $1974^{1 /}$

The Nation's need for oil from other nations is increasing despite efforts at conservation. Alaska oil will soon be arriving at contiguous U.S. coastal ports. Alaska and Mid-East oil will be carried in very large crude carriers (VLCCs), and ultra large crude carriers (ULCCs). The latter have a draught requiring as much as 100 feet of water.

Because these deep-draught vessels cannot enter U.S. ports without major modifications to the ports (deep dredging followed by continuous maintenance dredging), and because close-in to shore they bear a greater risk of going aground and spilling their cargo, much planning has gone into the construction of deepwater ports to off-load these vessels "at sea." Their oil would then be brought in via pipelines from the deepwater port for subsequent refining and transportation.

As with offshore drilling, the handling of vast quantities of oil in the marine environment represents substantial risk to fish, shellfish and other marine life.

The Deepwater Port Act seeks to authorize and regulate the construction and operation of deepwater ports in a manner that will prevent or minimize adverse impacts on the marine environment. Drafted in 1974, the Act acknowledges the environmental aspects of the following laws:

o The National Environmental Policy Act.

- The Federal Water Pollution Control Act.

o The Marine Protection, Research, and Sanctuaries Act.

o The Coastal Zone Management Act.

The legislative history accompanying the Act specifically recognizes that construction and operation of a deepwater port may degrade and despoil wetlands, estuarine areas, and wildlife habitats. The Act, therefore, establishes strict liability for oil spills associated with a deepwater port, and establishes a compensation fund for those harmed by a spill. 2 /

1/ P.L. 93-627, 33 U.S.C. 1501 et seq.

2/ The Act also directs the Attorney General of the United States to conduct a study on oil spill liability for spills from a11 sources. 
Deepwater ports will soon be a reality. Two deepwater ports have recently been licensed by the Department of Transportation. L0OP will be located off the coast of Louisiana, and SEADOCK will be located off the coast of Texas. The licenses contain conditions designed to minimize the likelihood of catastrophic spills, and chronic spills, leaks or bilge discharges. Failure of those conditions to prevent the occurrence of these events could result in serious damage to shellfish resources. These conditions are one of the results of consultations between the Secretary and the National Oceanic and Atmospheric Administration in 1975, when drafting regulations for site evaluation and preconstruction testing, and when establishing review criteria for evaluation of deepwater port applications.

H. Fishery Conservation and Management Act of $1976^{1 /}$

This Act extends the territorial limits of the United States -for fishing purposes--to 200 miles. Within the newly established fishery conservation zone, the Act establishes exclusive U.S. fishery management authority. Further, the Act calls for immediate action to conserve and manage fishery resources within the zone. Although the Act deals for the most part with finfish, its provisions are applicable to molluscan shellfish and would be of direct use in support of the surf clam found many miles out on the ocean floor. Most other molluscan shellfish are found within the Nation's (and individual states) traditional 3-mile limit, and there has been little controversy in international law as to their ownership. Because the Act speaks broadly of fishery resources, its authority could be relied upon to rebuild, restore, or maintain molluscan shellfish beds, and to prevent or minimize irreversible or long-term efforts on the resource and its habitat. This effect could be supported by the comprehensive fishery research program provided for in the Act.

Regional Councils established by the Act are to develop a plan for each stock of fish. This phrase, "stock of fish" includes molluscan shellfish, so it would be appropriate for the Councils to include the resource in their planning effort. There needs to be, however, a cooperative effort with the States, in which the resource is found, to implement the plan. It may be noted that regional plans that focus concern on spawning fish (such as salmon) will likely be considering the water quality of rivers and estuaries through which these species pass in their life cycle. Planning efforts directed at better management of those waters on behalf of anadromous and catadromous fish will be of benefit to molluscan shellfish.

I/ P.L. 91-190, 42 U.S.C. 4321-4347 
I. The National Environmental Policy Act of 1969 // and the Estuarine Areas Act 2

In the introduction to this section it was pointed out that these two laws serve to underscore the Nation's concern for the environment and, in particular, its estuarine environment. The Estuarine Areas Act provided a valuable service in calling for an inventory of the Nation's estuaries. That inventory was to focus, in part, on shellfish--their value and their potential.2/ The Estuarine Areas Act also contains a requirement that where a Federal agency's activities will affect an estuarine area, the agency must give consideration to the effects of those activities of the estuary. Further, where plans affecting an estuarine area are to be submitted to the Congress, the Secretary of the Interior, shall be afforded an opportunity to comment on those effects. This provision reinforces review provisions of the Fish and Wildlife Coordination Act of 1958, previously discussed.

The National Environmental Policy Act (NEPA) also requires agencies of the Federal Government to be responsive to environmental concerns when proposing legislation, or when considering the undertaking of a major action which will have a significant impact on the environment. An agency review mechanism established under the Act allows for comment by fish and wildlife agencies. Again, this is complementary to the Fish and Wildlife Coordination Act review mechanism, and is also complementary to the Estuarine Areas Act.

NEPA goes a significant step further than the Estuarine Areas Act. NEPA requires that a statement be prepared, regardless of whether the proposed project is to be submitted to the Congress, on every major action proposed. The statement, which has become known as the Environmental Impact Statement (EIS), must include the following:

o The environmental impact of the proposed action.

o Adverse environmental effects which cannot be avoided should the proposal be implemented.

o Alternatives to the proposed action.

1/ P.L. 90-454, 16 U.S.C. 1221-1226.

$\underline{2} /$ U.S. Department of the Interior, Fish and Wildlife Service, Washington, D.C., January 1970. 
J. The Water Resources Planning Act $1 /$

The Water Resources Planning Act presents a framework for river basin planning. The Act establishes a Water Resources Council composed of cabinet-level members and other agency heads, as appropriate. The President is authorized to establish river basin water commissions for related river basins. Although primarily concerned with the traditional matter of water quality, these commissions are required to consider environmental effects of a proposed plan including effects on estuarine areas. "Level B" plans are defined as regional or river basin plans. They are to resolve long-range problems, focus on mid-term needs, and recommend action plans and programs.

The Federal Water Pollution Control Act Amendments of 1972, directed the President, through the Water Resources Council, to complete "Level B" plans for all basins in the United States by January 1, 1980. Telephone communication with a staff member at the Water Resources Council indicated that this is an uncealistic goal.

\section{K. Research and Development Laws}

It is clear from the "Research Needs" section of this report that much is unknown about the effects of pollutants on molluscan shellfish. Several of the laws discussed have provisions for water quality research. These include:

- Federal Water Pollution Control Act Amendments of 1972.

o Marine Protection, Research, and Sanctuaries Act of 1972.

o Fish and Wildlife Coordination Act of 1958.

o Fishery Conservation and Management Act of 1976.

To this list may be added the following:

o Commercial Fisheries Research and Development Act of 1964.2/

o Anadromous Fish Conservation Act. $\underline{3}$ /

o Water Resources Research Act of 1964. 4/

1/ P.L. 89-80, 42 U.S.C., Sec. 1962 et seq.

2/ P.L. 88-309, 16 U.S.C. 779 et seq.

3/ P.L. 89-304, 16 U.S.C. 757

4// P.L. 88-379, 33 U.S.C. 1961 et seq. 
The Commercial Fisheries Research and Development Act was passed in 1964 to (1) stimulate research on the development of commercial fisheries, (2) develop new commercial fisheries, and (3) provide relief funds for commercial fishery failures due to a resource disaster arising from natural or undetermined causes. The Act's legislative history specifically describes a need for research on the effects of pollution on commercial fisheries. The Act specifically mentions shellfish and provides Federal cooperation in the development of commercial fisheries by supplementing state research and development funds.

The Anadromous Fish Conservation Act $t^{1 /}$ provides money for conserving, developing, and enhancing the anadromous fishery resources of the Nation that are subject to depletion from water resource developments and other causes, including water pollution.

\section{Summary}

Current Federal laws appear to be adequate for protection and restoration of water quality and for the production and harvest of molluscan shellfish resources if those laws were adequately implemented and enforced. Possible exceptions are nonpoint source controls, and problems for which improved technology is necessary, such as disinfection. Research results will, of course, improve the achievements of a11 these programs.

A number of Federal laws are important to the protection of water quality for molluscan shellfish resources. Principal among these are the Federal Water Pollution Control Act of 1972, the Marine Protection, Research and Sanctuaries Act of 1972, the Fish and Wildlife Coordination Act of 1958, as amended, and the River and Harbor Act of 1899. The following comments summarize the effectiveness of these laws:

\section{- Federal Water Pollution Control Act of 1972}

- Many administrative problems relate to the complexity and magnitude of the Act's undertaking and therefore explain some of the apparent lag in achievement of the objectives as of 1977.

- Progress is being made toward clean up and the 1977 goal of Best Practical Treatment. Full implementation has not been attained because requirements for guidelines, standards, criteria, regulations, surveys, and similar administrative mechanisms require development time. Legal tests, plus time for issuance of permits, construction and operation of facilities has meant that many abatement efforts now in progress are not yet operational.

1/ Anadromous fish begin their life in fresh water, migrate to saltwater and return to fresh water to spawn. The salmon is an example. 
- The permit program is difficult to evaluate due to the lack of current information, confused data, and non-compliance. Nationally, by July 1, 1977, 44 percent of the identified municipal dischargers and 62 percent of the identified industrial dischargers are expected to be in compliance with their permits. For the key coastal states, 48 percent of the identified municipal dischargers are expected to be in compliance with their permits.

- Shortcomings exist in compliance monitoring and enforcement partly as a result of manpower shortage.

- The construction grants program is lagging behind the schedule necessary to meet the 1977 goal, due in part to the impoundment of monies by the Executive Branch in the past.

- Urban storm runoff and combined sewer problems are inadequately addressed because of almost no action on areawide Planning or Leve1 B Planning under the Water Resources Planning Act.

- Reairements for disinfection substantially benefit the she11fish industry. However, the use of chlorine creates problems because of (a) questionable application techniques, (b) inadequate training of personnel, and (c) toxicity of chlorine to the biota in receiving waters. Research for new technology is needed.

- Lack of funding for advanced treatment, incomplete municipal compliance and discharge of nutrients from treated wastes creates the potential for eutrophic conditions.

- Non-point sources of wastes, particularly agricultural and urban runoff, may tend to obscure the effectiveness of the point source control program. Conversely, permit violations may tend to make pollution from non-point sources appear disproportionately heavy.

- Delay in implementing the Corps Section 404 regulation while awaiting court settlement of the Corps' title in dredged and fill material discharge has prevented attainment of full benefit from this provision of the Act. The Corps of Engineers proposed regulations are adequate to provide protection for shellfish resources in the placement of dredged and fill material.

- Implementation of the regulations for control of waste from water craft should result in elimination of most pollution from these sources by January 1980; in the interim, states may initiate action to protect shellfish waters by prohibiting a11 sewage discharges from water craft in certain circumstances. 
- Marine Protection, Research and Sanctuaries Act of 1972

- Enforcement of ocean dumping regulations may be inadequate and may result in dumping short of the legal distance offshore.

- Environmental consequences of ocean dumping are causing increased concern over the appropriateness of this practice.

- Fisheries research is ongoing, but there appears to be a low priority for shellfish.

- A few sanctuaries are designated, and some of these include shellfish.

- Fish and Wildlife Coordination Act of 1958

- Severe staffing and funding limitations of the National Marine Fisheries Service and the Fish and Wildlife Service make

- full implementation impossible.

- Implementation of this Act can ensure consideration of shellfish resources in all water related Federal permitting and construction activities.

- River and Harbor Act of 1899

- Implementation of the Corps of Engineers Construction Permit Program (Section 10) would be more effective if more consultative services could be provided to the Corps by the fish and wildlife agencies pursuant to the Fish and Wildlife Coordination Act.

- More effective enforcement of the Corps of Engineers regulations is needed.

- Coasta1 Zone Management Act

o Inventory and designation of geographic areas of particular concern by the States can result in major protection and restoration of water quality in important shellfish areas.

o The OCZM should not forward any State Plan for Secretarial approval unless all the requirements concerning "Areas of Particular Concern" have been adequately treated in the plan.

o State CZM agencies should be advised by State and Federal agencies, the fishing industry and the public concerning shellfish resource matters. 


\section{- Other Federal Legislation}

- Several Federal acts pertaining to fishery research provide the necessary authorities for research on water quality and shellfish resources which would supply information and technology necessary for protection and restoration of shellfish resources. 
A. Research Needs

1. Conclusion

There are a number of unanswered questions that have serious implications for the health of molluscan shellfish and the public. The problem of insufficient knowledge hampers adequate control efforts. The following topics are chief among the research needs.

- Confirmation of the scientific validity of the standard used to classify growing waters as "safe". Specifically, research is needed to define growing waters so that a balance may be achieved which will both protect human health as well as allow the safe harvesting of resources. Research is also needed to determine the toxicity of 'contaminants to both shellfish and consumers.

- A thorough examination of the literature to evaluate effects of flooding with particular emphasis on beneficial effects. The goal is a better understanding of the degree to which natural systems rely on and require fluctuations in fresh water, nutrients, and silt, both upstream and along the coast.

o Better understanding of the mechanisms of pesticide movement through soil, water, and air, its eventual transport to estuaries and the sea, and physiological pathways and rates of uptake and storage and the generation of metabolites.

- Investigations of the magnitude of the pesticide problem and the behavior of toxic substances in the environment; and development of alternatives to toxic compounds and updating of criteria, guidelines, and standards for management of toxic substances in the environment. This includes developing baseline inventory information as well as programs for routine sampling and monitoring.

- Substantive investigations into (a) reasons for the occurrence of those viral, fungal, and bacterial diseases of shellfish, (b) possible management alternatives such as continued support of efforts to develop resistant stocks, and (c) the subtleties included in the organism's susceptibility to disease (i.e., the chronic effects of heated water, change in diet due to eutrophic conditions, maximum allowable toxic levels in growing waters, and other man-induced activities). 
- Better understanding of the life cycles and the physical and chemical variables governing the behavior of predators of commercially important molluscan shellfish, in order to (a) be better able to predict predator "invasions," and (b) develop more sophisticated and effective control techniques.

- Continued investigations into plankton blooms leading to identification of the causative elements, recognition of conditions that bring the elements together, and development of an early-warning system to predict occurrences and allow precautionary measures to be taken before a bloom becomes a public health problem. Conclusive information would be used to support efforts to eliminate the cause(s) of plankton blooms.

- Conduct analyses of agricultural and silvicultural practices to (a) identify those of significance to estuaries, (b) characterize fully the consequences of the environmental hazards resulting from such practices, (c) examine existing and new pest control techniques and their economic and technical feasibility, and (d) develop background information supporting guidelines, criteria, and standards for these practices.

o Review available information and conduct new studies where necessary to clarify the controversy surrounding the role of treated cooling water from power plants with particular emphasis on the sublethal and chronic impacts (heat, toxic substances, radionuclides) to substantiate or refute current claims regarding molluscan shellfish.

- Examine the effectiveness of present treatment and disposal methods for domestic wastes, with special attention to (a) the relationship between toxic wastes and biological treatment systems, (b) further development, testing, and demonstration of cost-effective alternative methods to chlorine disinfection, sludge disposal (uther than ocean dumping), and the collection, storage, treatment, and potential uses of stormwater.

- Evaluate waste contributions to coastal waters from small scattered, low-income coastal communities and private residences, with special attention to seasonal variations. The evaluation should also include a review of the state of the art to identify existing and alternative treatment systems. 
- Expand and develop existing information bases to increase our predictive capabilities, with special attention to:

- The resuspension of contaminants as a result of dredging activities and their subsequent behavoir in the environment.

- The alterations of salinity and current patterns and the long-term consequences.

o Examine the relevance and adequacy of existing techniques such as interbasin transfer and upstream impoundments for meeting water supply demands, including consideration of the feasibility of other techniques such as desalination and reuse (followed by testing and demonstration where applicable).

- Examine possible effects on water resources of new energy

- generation methods such as wind or solar devices. This analysis should be cursory and generally limited to examination of planned systems for cooling requirements and major emitted pollutants (if any).

- Review existing studies to collect and integrate information on chemicals concerning regulatory control techniques for manufacturers and users. There is a need to determine the present and future usefulness of these techniques, to identify candidates for replacement and suggest viable alternatives.

o Develop an adequate information system to provide timely, accurate, and complete data on human health effects and ecological effects.

\section{Option}

An option is to direct research toward the needs identified above, with a level of funding reflecting the seriousness of unknown impacts. Several of the laws discussed in Section VI have provisions for research dealing with water quality and molluscan shellfish resources. They include the:

o Federal Water Pollution Control Act of 1972

o Marine Protection, Research, and Sanctuaries Act of 1972

- Fish and Wildlife Coordination Act of 1958

o Fishery Conservation and Management Act of 1976 
o Commercial Fisheries Research and Development Act of 1964

- Anadromous Fish Conservation Act of 1965

o Water Resources Research Act of 1964

B. Fish and Wildlife Coordination

\section{Conclusion}

Most fish and wildlife agencies, the National Marine Fisheries Service in particular, are so severely understaffed and underfunded that full implementation of their responsibilities under the Fish and Wildlife Coordination Act of 1958 cannot be achieved. Particularly critical is the case load for review of Sections 10 (Rivers and Harbors Act of 1899) and 404 (FWPCA of 1972) permits, NPDES permits, and Federal projects.

\section{Option}

a. The primary option is to adequately staff and fund the fish and wildlife agencies. Existing procedures would allow an adequate review of permits and projects if this were done.

b. A supporting option would be to achieve passage of the proposed amendments to strengthen the Fish and Wildlife Coordination Act as set out in the national program by the Department of Commerce. These amendments would expand coverage to additional Federal developments including OCS activities; clarify the role of NMFS under the Act; strengthen mechanisms for consideration of fisheries in planning decisions for water developments and permits; and provide for transfer of funds from Federal construction and licensing agencies to the fish and wildlife agencies for FWCA study purposes.

\section{Shellfish Growing Waters}

\section{Conclusion}

Based on increases in Prohibited areas in the years 1971-74, degradation is continuing, but nationally at only half the rate of the 1966-1971 period. Several states show decreases or little or no increase in Prohibited areas, while others show significant increases. The lack of universal standards for classification of waters and record keeping makes absolute changes difficult to discern.

It seems clear that the greatest negative impact on the sanitary condition of growing waters is still the domestic waste discharges. Siltation from upstream sources, the effects of dredging and filling operations, chemical contamination, and other problems associated with water quality and shellfish resources also contribute to the overall losses and alterations. Dollar value of losses caused by additive pollutants are variable, however, and in most cases cannot be determined. 
The EPA National Enforcement Investigation Center has no plans to continue data collection and publication of the National Shellfish Register of Classified Estuarine Waters. The FDA Shellfish Sanitation Branch has indicated they do not plan to assume the responsibility. The document is an important resource management tool.

\section{Option}

Special attention should be given to municipal construction and permitting programs; funding should be increased for the planning and construction of treatment facilities; and a mechanism should be devised to (a) segregate permits affecting shellfish waters for special attention, especially those in seed processing areas, and (b) explore class action permits. This procedure would allow concentration on the review of permits for discharges with the greatest potential to adversely affect shellfish waters. Immediate attention should be given to publication of the National Shellfish Register on an annual basis with expansion of data to include more detailed information on water quality and molluscan shellfish.

\section{Water Quality Control Laws}

\section{Conclusion}

The existing laws, if fully implemented, should result in clean water and a healthful shellfish environment. There are, however, implementation problems.

To have an accurate measure of the effectiveness of these laws, specifically the Federal Water Pollution Control Act Amendments of 1972, one would have to inventory the Nation's shellfish beds on July 1, 1983, to determine the viability of the resources. One can say, however, that as of 1977 shellfish beds are closed to harvesting because of water quality problems, and that the mechanisms provided by law are only beginning to achieve positive results. The permit program of the Federal Water Pollution Control Act Amendments of 1972 is of particular importance to molluscan shel1fish. In the 23 coastal states (including Hawaii), 90 percent of the identified municipal discharges have been issued permits. However EPA estimates that only 50 percent of that number will be in compliance by July 1977 . Nonmunicipal dischargers are estimated to have a higher percentage of compliance. of concern also to the interests of the molluscan shellfish industry are programs dealing with urban-agricultural runoff through areawide waste management, and Level B river basin planning.

\section{Option}

There should be full implementation of all Sections of the Federal Water Pollution Control Act Amendments of 1972, with particular emphasis on construction grants, NPDES, water quality standards, compliance and enforcement, research and development, areawide waste treatment and river 
basin planning. The program of the Water Resources Council to carry out a "Level B" river basin plan for every river basin by 1980 should be accelerated, with special emphasis on coastal river basins.

\section{E. The Coastal Zone Management Act of 1972}

\section{Conclusion}

This Act has particular potential for protection and restoration of shellfish producing waters. Section 305 and 306 require a State inventory, designation procedures and protective actions for Geographic Areas of Particular Concern in the State CZM plan. Under this procedure, any State could designate, protect and restore quality of all its shellfish waters and provide long range protection and management.

It appears that this element of the CZM program is not receiving adequate emphasis in some States. The State and Federal fishery agencies, fishing industry and the public need to advise the state CZM planners of the need to identify, designate and protect estuarine systems containing she11fish resources.

\section{Option}

a. The State CZM offices should consult State and Federal fishery agencies concerning shellfish resource needs in connection with inventory, designation and protection of "Geographic Areas of Particular Concern."

b. The fishing industry, the public, and the State and Federal fishery agencies should advise the State CZM Planners of shellfish resources and the need for "Geographic Areas of Particular Concern" during public hearings and other State CZM planning activities.

c. The Office of CZM should not forward any State CZM plan to the Secretary of Commerce for approval until all requirements for inventory, designation, protection and restoration of "Geographic Areas of Particular Concern" have been fully complied with as specified in Sections 305 and 306 of the CZM Act of 1972 and in 15 C.F.R. 923.13(b).

\section{F. Consistent Agency Jurisdiction}

\section{Conclusion}

Several Federal and state agencies hold responsibilities for direct and indirect implementation and enforcement of regulations to protect molluscan shellfish resources and their habitat or to insure consumer quality for shellfish harvested from estuarine waters.

o State governments are not uniformly organized, but involved state agencies usually include: 
- A fishery agency to manage and regulate the harvest of shellfish resource and which handles FWCA responsibilities for the State.

- A pollution control agency to classify waters, set standards, regulate discharges, monitor quality, and enforce pollution laws.

- A public health agency to insure that public health aspects of shellfish products are adequate.

- A State Coastal Zone office which is charged with planning and zoning to insure compatible land use and habitat protection.

- Key Federal agency roles include:

- EPA - Oversees pollution control programs of Federal and State Government. They define guidelines and standards, issue NPDES (waste discharge) permits unless the state has assumed that program, and insure state performance and enforcement of Federally approved state pollution control programs. EPA enforces Federal permits and state permits it the state defaults. Advises State and Federal permitting agencies concerning the impacts of proposed actions on water quality.

- Corps of Engineers - Issues Federal permits for construction (dredging, piers, etc.) in U.S. navigable waters, permits for ocean dumping of dredged material.

- U.S. Coast Guard - Issues Federal permits for bridges in navigable water, enforces ocean dumping, enforces marine sanitation devices and assists $\mathrm{COE}$ in monitoring compliance with construction permits.

- The NMFS and F\&WS (and state fishery agencies) under the FWCA advise the state and Federal permitting agencies concerning the impacts of their proposed actions on water quality and fish and wildlife, including shellfish.

- Food and Drug Administration - Establishes safety standards to protect the public health in shellfish products harvested and shipped in interstate commerce.

The implementation of these several programs to meet the objective of obtaining clean water involves specific responsibilities and special expertise within each agency. The programs and mechanisms are available to achieve pollution abatement, resource management, and to insure product safety for the consumer. The need for strengthening the program funding, staffing and administration has already been expressed. Simplification and streamlining of the management and regulatory procedures wherever possible without loss of effectiveness is essential. Meeting this need will 
minimize potential interface problems among the many entities involved, thereby insuring program efficiency. Good cooperation, supported by adequate exchange of data, is particularly necessary as is good communication between all governmental interests and the shellfish industry.

\section{Option}

Federal water quality regulations require constant reevaluation with regard to responsibility of origin, technical adequacy, implementation, and enforcement, so that deficiencies and conflicts can be identified at an early stage and minimized. In addition to achieving passage of amendments to strengthen the Fish and Wildlife Coordination Act, the option of using oversight hearings as a vehicle to examine the effectiveness of associated programs would be of value.

To see that its interests are protected, the molluscan shellfish industry should participate in all State and Federal regulatory procedures effecting shellfish waters. These include among others the review and establishment of water quality standards and Coastal Zone Management Activities such as inventory and designation of "Geographic Areas of Particular Concern" and definition of policies and actions to protect such areas. 


\section{LIST OF APPENDICES}

Appendix A

Appendix B

Appendix C

Appendix D
Studies . . . . . . . . . . . A

Legislation • • • • • • • . B

Contacts and Interviews . . . . . $\mathrm{C}-1$

Bibliography . • . . . . . . 
Appendix A

CASE STUDIES

CONTENTS

1. Scarborough, Maine.. . . . . . . . . . . A-1

2. Great South Bay, Long Island, New York . . . . . . A-4

3. Raritan Bay and the New Jersey Coast . . . . . A-8

4. Choptank River Basin, Maryland . . . . . . . . A-13

5. Virginia .............. . $\mathrm{A}-17$

6. Mississippi River Delta, Louisiana . . . . . . . A-21

7. Washington State .............'. A A-26

8. Apalachicola Bay, Florida . . . . . . . . . A-32 


\section{Scarborough, Maine $\underline{\underline{1} / \underline{2} / \underline{3} /}$}

Scarborough, Maine was selected as the subject of a case study because of localized opposition to pollution abatement and proximity to a valuable molluscan shellfish habitat. The resulting problems are typical of those in many areas along the coastlines of the United States. Scarborough is a predominantly residential community within the Greater Portland Metropolitan area. The town, favored by its clam resources, proximity to Portland, good regional transportation, and attractive residential neighborhoods, has good growth potential. Further development, however, is constrained by lack of adequate sewage collection and treatment facilities within the town.

At present, only the Oakhill area of Scarborough is served by a public treatment plant. Other areas rely on individual septic systems. Poor soil conditions throughout the town cause frequent septic system malfunctions and failures. As a result, untreated sewage finds its way into the various bodies of water in Scarborough, severely degrading water quality in these areas. Other major waste sources include untreated sewage discharged from private lines into the ocean, and raw sewage overflowing from cesspools into adjacent waterways. Also contributing to wasteloads is the Higgins Beach area where over 200 households discharge their raw sewage into a septic tank with a holding capacity of 1000 gallons. The resulting seepage flows into the marsh area of the Spurwink River near the Higgins Beach swimming areas. This beach has already been closed to swimming because of water pollution.

In an effort to prove the water quality in the town of Scarborough, the Scarborough Sanitary District has submitted an application to EPA, Region I, requesting Federal funds to design and construct a major collection and treatment facility to serve the Scarborough area. Several alternative plans have been reviewed by EPA, and of these, two have received primary consideration.

1/ "Environmental Impact Statement on Wastewater Collection and Treatment Facilities for Scarborough, Maine," Draft Report, U.S. Environmental Protection Agency, December 1975.

2/ "Sanitary Survey Report of Scarborough, Maine," Maine Department of Marine Resources, 1974.

3/ Some of the data for this section were obtained from personal interviews with representatives from State and Federal agencies as well as documents provided by them. 
One plan, which EPA favors, calls for an internal Scarborough system combined with a single treatment plant and an ocean outfall located off Prouts Neck, an affluent suburb within the town. The other calls for total transfer of Scarborough wastewater to a treatment plant in South Portland. Either system would abate water pollution. Implementation of the Prouts Neck alternative, if approved could begin immediately. Construction of the South Portland alternative would involve delays. The State of Maine has already approved a project to expand South Portland's wastewater treatment system. A decision now to transfer Scarborough's wastewater to Portland would require not only changes in the South Portland plant's design, but also time-consuming negotiations between the two communities. It is EPA's view that delays associated with the South Portland system are unacceptable.

A primary consideration in EPA reasoning is the Scarborough clam flats. This resource is among the richest in the State of Maine. The clam growing areas in Scarborough, however, have been closed to open harvesting since 1971 because of water quality problems. These flats, if reopened, could contribute as much as $\$ 3$ million a year to the Scarborough community, a sum that is significant in view of the fact that the town of Scarborough has little industry and few employment opportunities. Snow Foods, one of the two food processing plants in town, cannot use the local clams to process clam chowder.

In addition, tourism, which also has good growth potential and could contribute to the Scarborough economy, is limited by the town's inadequate sewage system, which threatens recreational water use. Implementation of the preferred plan will improve existing water quality and be of substantial benefit to the town's clam industry and to recreational harvesting. Because of the small scale of the project, its other effects on the manmade environment would be minimal.

The Prouts Neck wastewater collection and treatment system, however, is not acceptable to all members of the Scarborough community as the best possible alternative. Several questions have been raised concerning the potential socio-economic and environmental effects of the proposed system on the town. In particular, it is asked whether the proposed system would generate excessive growth within the town. Another frequently expressed concern is the possibility of the treated effluent finding its way back to the Scarborough swimming areas, thus creating a health hazard. The strongest opposition, however, comes from the residents of the Prouts Neck area who object both to the placement of the ocean outfall off Prouts Neck and to the treatment plant being located within the community. In an effort to settle the ongoing debate over the proposed system, EPA has recently drafted an environmental impact statement on the project. However, because of continued controversy, a final draft is pending. Thus, the entire matter remains unresolved. 
It is interesting to note that earlier studies have determined Prouts Neck to be the optimum location for the proposed ocean outfall. Further, it has been reported that the treated effluent discharged from the outfall will have a minimum impact on water quality in the area where it will be constructed, which at present is suitable for recreational purposes and shellfish harvesting.

The residents of Prouts Neck are not completely unconcerned about the improvement of water quality standards in Scarborough. Even though the proposed project was rejected, several alternative systems were suggested (of which the. South Portland plan discussed earlier was considered to be the most feasible). However, it was strongly implied by those interviewed that the Prouts Neck opposition to the new system, which is said to be based on its potential threats to the environment, is in fact an attempt to shroud their real concerns, which may be based on aesthetic rather than environmental considerations.

In summary, it must be emphasized that the clam flats are the major considerations in EPA's pollution abatement activity in Scarborough. Revenue from this resource is denied the community because of serious water quality problems in and around Scarborough. Further, absence of adequate sewage treatment facilities stifles town growth and development. It appears, therefore, that implementation of the proposed system will improve water quality, with subsequent benefits to the clamming industry. Reliable studies report that the proposed facility preferred by EPA is the best available alternative. Nevertheless, significant comments against the proposed project continue. Certain questions raised by residents of Scarborough deserve serious consideration, while others appear to have been raised only to delay construction of the proposed system indefinitely. The Prouts Neck waste treatment controversy typifies the problems frequently encountered by EPA in its efforts to abate pollution. 
Great South Bay was selected for study because of typical communication difficulties among State, Federal, and local agencies charged with pollution abatement and molluscan shellfish management responsibilities. Four principal factors intensify this problem: a high volume of nutrients contributed to the Bay, private and town ownership of the Bay, many sources of contaminants around the shore, and highly productive shellfish beds within the Bay.

Great South Bay, located off the south shore of Long Island along Suffolk and Nassau Counties, New York, is the largest of a series of estuarine areas protected from the Atlantic Ocean by a barrier beach. It is approximately 30 miles long and six miles wide at its broadest point. There are 70,000 acres of aquatic habitat, 6000 acres of undisturbed marsh, as we11 as shoals, mud flats, open saltwater areas, freshwater tributaries, and seeps. I/

A low elevation and high water table characterize Long Island freshwater flow properties. Direct runoff following rainstorms generally contributes only a small amount of annual streamflow. It is estimated that only five percent of the total streamflow on Long Island results from direct runoff. The other 95 percent comes from ground water seepage. 2 /

Great South Bay is one of the most productive shellfish grounds in the United States. I/ There are 58,280 acres of shellfish growing waters, 3,870 of which were closed in 1974 and remained closed in 1975.

The molluscan shellfish industry is the most lucrative of the commercial fishing industries in New York, and Great South Bay is the largest producer. Hard clams, which bring a price of up to $\$ 50$ dollars per bushel are the principal resources. Large stocks occur in closed waters and entice shellfish poachers to harvest them. Cultivation of the eastern oyster, once prevalent in the Bay, is now significantly reduced.

In general, Federal and State agencies and the local townships do not perform an adequate job of enforcement of closures due to a lack of facilities and personnel. State coordination with local police forces, water patrols, and even the courts would probably improve the illegal harvesting problems.

The newly created Bureau of Shellfisheries now handling the sampling and classification of waters has been charged with the management of the State shellfish resource program. Although the program is working better than it was five years ago, enforcement which is a responsibility of the

\footnotetext{
1/ "National Estuarine Study," U.S. Department of the Interior, Fish and Wildlife Service, January 1970.

2/ "Draft Environmental Impact Statement for Fire Island to Montauk Point, Department of the Army, Corps of Engineers, March 1976.
} 
conservation offices of the Division of Law Enforcement is a continuing problem. Patrolling is not always adequate in certain areas. This is primarily due to a lack of funds and to cutbacks in personnel. In addition, industrial and municipal plants are not always inspected as frequently as is necessary to enforce the discharge permit program.

Conservation officers are required to send a weekly report on their activities to the Division of Law Enforcement. There have been frequent reports of illegal harvesting (i.e., from uncertified areas) in the Great South Bay. According to FDA, between March 1974 and March 1975, there were 103 arrests made by State officials for illegal harvesting. I/ Most of these arrests resulted in reduced-charge convictions.

It is evident that this area needs constant surveillance as a deterrent to would-be offenders. It has been suggested that the courts have been unduly lenient. It has also been suggested that there is a need for better coordination of local police activities with the state agencies. It has been recommended by one Federal agency that in areas where shoreline patrols are scarce due to inadequate manpower, agreement could be negotiated with local authorities to share in patrolling responsibilities and to coordinate their activities with the State.

Some problems have developed with the present classification of approved growing waters in New York. Recommendations to close 1600 acres of growing area in Great South Bay were made by the New York State Department of Environmental Conservation, Bureau of Shellfisheries in Stonybrook. The situation is currently being reviewed, but the areas are still classified as approved. FDA has also indicated a need to reclassify these waters based on State findings.

Several programs are currently ongoing in the Bay to conserve the hard clam resource through methods of relaying clams from condemned waters to approved waters for cleansing. This again requires the cooperation of State and local agencies. FDA is encouraging the expansion of this activity. In 1975-76, three townships in the Bay area were involved in the programs; Babylon, Islip, and Brookhaven. The State pays for the operation and is reimbursed by the townships. The townships receive 50 percent matching funds from the U.S. Department of Commerce, National Marine Fisheries Service, under Public Law 88-309. The acceptance of these Federal funds by the townships, however, may cause a loss of sovereignty over growing areas by placing on the townships obligations imposed by the Federal government. Thus, certain townships are sometimes reluctant to participate in relaying activities even in totally closed areas.

The relaying process has proved successful but requires adequate cleansing and constant monitoring for poaching violations. Relaying is conducted in the western portion of Long Island Sound mostly by the towns. Shellfish in the Bay are relayed to public grounds.

1/ Private Communication 
In the early settlement of Long Island, much of the western Bay bottom land was granted to individuals, first by the Dutch via patents, then by the English. Large portions of the eastern half of the Bay are in the hands of towns or of private citizens as one of the provisions of 17 th Century grants from the King of England.

The current complications of a rapidly growing population and the resulting impact on the environment can be expected to continue in Suffolk County. In the 1960 's, over a seven-year period, more than 1100 acres of estuarine habitat were destroyed or degraded by dredging and filling operations related to development in the Great South Bay, Nassau County area. I/ It has been projected that by $1985,1.5$ million of the additional six million people that will inhabit the New York region will be living in Nassau and Suffolk Counties. Since the north shore in Nassau County and the western area, in Suffolk County have already been taken up by urbanization, the pressures for development will be on the remaining vacant lands, mostly privately owned, in central Suffolk County. As a result, the remaining wetlands are in jeopardy.

A11 Federal and State agencies seem to concur on at least one point: Storm runoff and groundwater contamination are the major causes of water quality degradation in most of the Long Island shellfish areas. A prime example of this is in southeast Nassau County. One hundred percent of the county is sewered. However, the waters are still closed for shellfishing because of stormwater runoff problems, ineffective sewage treatment, and sewage treatment plant overflows. In addition, there is the political problem of trying to convince local townships to spend more time and money to clean up these waters and to enforce closures.

Increased treatment plant construction and upgrading is being planned, but it is not certain that the results will be beneficial since it can be argued that these plants will not solve the problems in heavy runoff areas. In the case of the Southwest Sewer District Ocean Outfall project which will include a sewage pipeline under the Bay to discharge in the ocean, the project has the approval of both the New York/New Jersey Region Environmental Protection Agency and the New York District Army Corps of Engineers. However, Department of the Interior personnel suggest that two potential problems remain unresolved in connection with the project, as proposed, which may affect shellfish:

1. No indication has been given as to the long-term effects of a change in salinity for the Bay due to the decreased stream runoff which would result from implementation of the proposed new sewage treatment plant.

2. Bottom habitat alteration and loss may result from dredging and back filling operations. 2 /

\footnotetext{
1/ "National Estuarine Study," U.S. Department of the Interior, Fish and Wildlife Service January 1970.

2/ Private Communication.
} 
Most of the new buildings along the shore have been using some form of subsurface disposal system resulting in removal of bacteria, but they have increased the rate of phosphates and nitrates that enter the Bay through groundwater systems. This, together with the runoff from new shopping centers and the increase in recreational boating wastes, is detrimental to the water quality of the Bay. Recreational boating wastes continue to be detrimental despite a State law requiring pump out facilities.

A significant but more controllable source of contamination is duck farm wastes. In the Moriches Bay area, which is connected by channel to Great South Bay, there are 16 of these farms, all with National Pollution Discharge Elimination System (NPDES) permits. At one time most of the Great South Bay area was closed to molluscan shellfishing because of duck farm waste discharges. The major result of these discharges was the introduction of large amounts of nitrogen into shellfishing waters. This can alter the food supply by causing an increase in certain species of plankton that are not the preferred food of the shellfish, and also by causing a depletion of the preferred food. An increase in sheer plankton numbers may also clog the gills of these filter feeders. Currently, contamination from the duck farms is under control.

The future of Great South Bay molluscan resources will depend on management agencies correctly perceiving the problems, and achieving a better balance of social and economic interests with resource preservation and enhancement. 


\section{Raritan Bay and the New Jersey Coast}

Water pollution problems in the Raritan Bay area are serious enough to result in complete closure of the entire Bay and ancillary embayments and rivers, except for the Navesink and Shrewsbury river complex. The estimated overall flushing time for the entire Bay System is 32-42 tidal cycles or 16-21 days. 1 /

In the early 1900s the Bay was a major resource for hard and soft clams and oysters. The oyster industry collapsed because the waters where they grew became polluted by industrial wastes. The available hard clam resource for direct marketing has diminished by 100 percent since 1900, and soft clams that are harvested must be depurated.

An outbreak of hepatitis in 1961 was traced to consumption of raw shellfish from the Bay. This resulted in closure to all shellfishing areas by order of the New Jersey State Commissioner of Health. 2 / The Raritan Bay closure resulted in a minimum of 3,000 men being put out of work. About 2,850 acres that had been utilized for shellfish harvesting were lost, resulting in an approximate loss of $\$ 8.5$ million (dock value) annually to the economy. $3 /$ The area is still closed for direct marketing of she11fish. Harvesting oysters and hard clams is permitted for transplanting to approved areas for cleansing, but is not practical. Soft clams are harvested and subsequently cleaned in a depuration plant.

The origin of high fecal bacteria counts has been traced to many inadequate sewage treatment plants and to raw sewage from sources in New Jersey and New York. The 1974 EPA analysis of the Bay's water quality 4 / indicates five wastewater sources: (1) waste loading entering the Bay from Arthur Kil1, (2) wastewater discharges from the New York Harbor System, (3) waste loading frcm the Middlesex County Sewerage Authority treatinent facility (Note: completion of conversion to a secondary plant is anticipated by 1977 / /), (4) other point source waste loading, and (5) upstream discharges.

1/ "Water Quality Analysis of the Raritan-Lower Bay System," U.S. Environmental Protection Agency, December 1974.

2/ "The National Estuarine Pollution Study," Report in Congress, Senate Document No. 91-58, Secretary of the Interior, March 1970.

3/ "Pollution Control in the U.S.--Some Recent Accomplishments," a Report to the Deputy Administrator, U.S. Environmental Protection Agency, November 1976.

4/ "Water Quality Analysis of the Raritan-Lower Bay System," U.S. Environmental Protection Agency, December 1974.

5/ "New Jersey Water Quality Inventory," pursuant to Section 305(b) of P.L. 92-500, State of New Jersey Department of Environmenta1 Protection, May 1976. 
EPA also points to potential toxic substances and other pollution pouring into the Bay from industrial discharges in the western portion of the Bay. There are cooper discharges into the Bay system, but no copper permit standards. This problem is complicated, or intensified, in the western end of the Bay due to the poor hydrodynamic, physical, and flushing characteristics that are unique to that portion of the Bay. The eastern portions suffer less because of the influx of cleaner ocean water. I/ Also, New York's water pollution program has increased in effectiveness since implementation of P.L. 92-500.

The New Jersey/New York boundary runs down the middle of the Bay and through the mixing area for effluents from the Raritan River, Sandy Hook, and Arthur Kill (New Jersey), and from the Hudson, Staten Island, and Arthur Kill (New York). In general cooperation between New York and New Jersey on interstate pollution appears to be reasonably good in the judgment of personnel interviewed at the New Jersey Environmental Protection Agency, Division of Water Resources. However, there have been cases when halting of chlorination by New York City officials has added pollution to Raritan Bay. Cooperation is perhaps aided by the fact that although New York presents problems larger in scope, its economic resources are more adequate to deal with them, and New Jersey, though not as economically able to cope with the problems, represent a smaller-scale threat to water quality.

The nature and extent of pollution problems on an interstate basis is exemplified by the 1976 algal bloom and subsequent massive fish and shellfish kills, including surf clams and sea scallops, along the entire New Jersey coast. While there has been no confirmation of a direct causeand-effect relationship between the waste disposal area and the fish kill, the conditions were such that the quantity and constituents of the waste material could well have caused or have been implicated in such a phenomenon.

The fish kill was first observed in late June 1976. In early October 1976, oxygen levels had recovered somewhat, but many marine animals had been killed. The fish kill extended from south of Manasquan Inlet to just south of Atlantic City. It extended out into the ocean to depths of 30 fathoms. The area affected was 2100 to 2200 square miles. Refined estimates indicate that the quantities of surf clams affected are greater than previously anticipated. The Food and Drug Administration on April 1, 1974 issued a warning concerning the harvesting of mollusks in an area

1/ "New Jersey Water Quality Inventory," pursuar,t to Section 305 (b) of P.L. 92-500, State of New Jersey Department of Environmental Protection, May 1976. 
in the New York Bight Apex. A complete report on the incident is being prepared by personnel of the Sandy Hook Laboratory, Northeast Fishery Center, NMFS.

Although the kill is complex and little understood, the possibility exists that events occurred in the following sequence. $\underline{1}$

(1) Presence of levels of essential and abundant algal nutrients (phosphates and nitrates) not generally present in the ocean but available in (a) the sludge disposal area--the New York Bight, (b) ocean outfalls of treated sewage from New Jersey shore communities, and (c) discharges into Raritan Bay and New York harbor from the Hudson River drainage system.

(2) Dispersion of sludge wastes and sewage effluents by bottom currents.

(3) Proper concentration and nutrient conditions created for algal bloom.

(4) Algal bloom; slow at first, increasing exponentially.

(5) As available nutrients were consumed, die-off rate of algae increased.

(6) As die-off rate increased, massive settling occurred and bacterial decomposition increased with attendant increase in oxygen demand.

(7) Development of thermally stratified water layers (thermocline).

(8) Oxygen depletion and creation of an anaerobic water layer.

(9) Suffocation of bottom dwelling mollusks.

(10) As anaerobic conditions moved southward along the New Jersey coastline, other productive surf clam and scallop beds were overlain with anaerobic water layers and were also affected.

The New York Bight is the prime dumping area for sewage sludge, dredged materials, dirt, industrial wastes, and wrecked vessels. Currently,

1/ "Mortalities of Fish and Shellfish with Anoxic Bottom Water in the Middle Atlantic Bight," U.S. Department of Commerce, National Marine Fisheries Service, Middle Atlantic Coastal Fisheries Center, September 1976 . 
about four million cubic meters (5.2 million cubic yards) of sewage are dumped in the Bight annually and three billion liters of sewage enter the ocean daily from the Hudson River outfall.

Alternative ocean dumping sites have been suggested, but possible adverse effects on bottom-dwelling organisms near those sites were found to be unacceptable. EPA recommended continued use of the present dump site, and designated an alternative site for future use, if necessary, with close monitoring for potential hazards arising from the present dump site in the Bight.

Over the years, urbanization and industrialization have replaced the former agrarian complex on the Raritan Bay, Hudson River and Havesink and Shrewsbury River Valleys. During that time many millions of gallons of untreated sewage have flowed into the Hudson-Raritan estuarine system. These major projects partially funded by EPA (a 15-mile outfall 1ine and two treatment plants) were built that have led to improving water quality, thus allowing two-thirds of the Bay's 25,250 acre estuarine area to be reopened on a restricted scale to some forms of shellfish harvesting such as relaying and depuration. $\underline{2} /$

There are many new treatment plants under construction, and plans for upgrading in many problem areas are underway. The Section 208 areawide studies will address point as well as nonpoint problems. $3 /$ This would seem to indicate a future trend of improvements, although sufficient data are not available to determine whether water quality will be upgraded prior to 1983. 3/ Future plans for water quality cleanup in the Bay area (some New York projects included) should impact favorably on the shellfish growing area. The New Jersey Water Quality report $3 /$ indicates that approximately 15 million gallons per day (MGD) of effluent have been or will be transferred from the Bay and its tributaries to the Atlantic Ocean ultimately to be increased to 45 MGD to allow for growth), and that 80-90 MGD of primary effluent issuing from the Middlesex County Sewerage Authority facility will be upgraded to secondary treatment by 1978 .

The following suggestions for future research, growing area management practices, and pollution abatement programs have been made by State and Federal personnel:

1/ "Draft Environmental Impact Statement on the Ocean Dumping of Sewage Sludge in the New York Bight," U.S. Environmental Protection Agency, February 1976.

2/ "Pollution Control in the U.S.--Some Recent Accomplishments," Report to the Deputy Administrator, U.S. Environmental Protection Agency, November 1976.

3/ "New Jersey Water Quality Inventory," pursuant to Section 305 (b) of P.L. 92-500, State of New Jersey Department of Environmenta1 Protection, May 1976. 
o Increase relay and transplant programs, and patrolling of existing relay areas. The need for heavier patrolling of these areas also implies a need for additional manpower in order to avoid a cutback on survey activities.

o Continue improvement of waste treatment, with greater emphasis on nonpoint source pollution abatement programs. Reassessment of water quality improvement trends, once the Section 208 studies have been implemented.

o Establish standards or action levels for heavy metals and other toxic chemicals.

o Conduct studies to define the significance of benthal oxygen demand and photosynthetic production during the critical summer and fall months.

c Terminate ocean dumping. 


\section{Choptank River Basin, Maryland}

The phenomenon of interest in the Choptank River is the relationship between the characteristics of a large (approximately 600,000 acres), predominantly agricultural drainage basin and a proportionately sma11 (approximately 7,000 acres) but significant molluscan resource. The significant impact of agricultural runoff on clams and oysters is intensified by activities associated with recreational boating, channel dredging, and lowlevel urbanization.

The Choptank River has shown some improvement in its water recently, which was attributed to upgraded sewage treatment. The problem of high nutrient levels may still be difficult to solve completely in areas experiencing heavy runoff.

The total area of the Basin, including the water surface area, is about 867 square miles, draining in a southwesternly direction toward Chesapeake Bay. The surface of the basin is a low, flat to gently rolling plain characterized by a variety of geographic features--terraces, remnant dunes, basinlike depressions, stream channels, swamps, marshes, and coasta1 waters-with a coastline of irregularly indented inlets and bays, and tidal rivers and creeks. 17

Some of the soils in Dorchester, Talbot and Caroline Counties are deep, well drained, and suitable for septic systems. Other types are less favorable for septic disposal, particularly during the rainy winter months.

Oysters and soft-she11 clams are commercially harvested in the nearly 7,000 acres of the Choptank River region. A recent survey by the Department of the Interior indicated that the average annual harvest between 1966 and 1970 was 219,000 pounds of soft-shell clams (valued at $\$ 69,000$ ) and 2,281,000 pounds of oysters (valued at $\$ 1,445,000) . \underline{2}$ I

Some molluscan shellfish areas in the Choptank River are frequently opened and closed because of fluctuations in quality due to inadequately sewered urban regions. Previously closed shellfish waters in the upper portions of Little Choptank River were opened in August 1975. 3 / One reason for recent improvement of water quality in the area was suggested to be an extremely dry year. This may indicate that stormwater runoff is a highly significant source of pollution in this area.

The Water Resources Administration (WRA), Department of National

1/ "Choptank River Basin Water Quality Management Plan," Maryland State Department of Natural Resources, Water Resources Administration, November 3, 1976.

2/ "Chesapeake Bay Future Conditions Report," U.S. Department of the Interior, Fish and Wildlife Service, January 1976.

3/ "Maryland Water Quality," pursuant to Sec. 305(b), P.L. 92-500, State of Maryland, 1976. 
Resources (DNR), writes the permits and administers its own National Permit Discharge Elimination System (NPDES) program. The divisions within WRA and the Maryland Environmental Health Agency are responsible for the inspection, investigation, and enforcement of the NPDES program.

In this river basin the point discharges are both municipal and industrial. In 1975, nine sewage treatment plants (STPs) and 12 seafood processing plants were required to specify improvements to upgrade waste treatment. Primary treatment plants, inefficient secondary treatment plants, and/or plants that combine storm drain and sewer systems cause the most severe problems.

The Maryland Department of Natural Resources has projected that by 1980 in some areas, such as along the Tred Avon River, population growth will be responsible for routine overloads. 1 Although the city of Cambridge provides secondary treatment, the collector system has 17 overflow points that cause surface pollution problems. During heavy rains, overflows in combination with raw sewage, industrial wastes, and stormwater return untreated waste back into Cambridge Creek and the Choptank River, The town of Secretary, near the Choptank River, has a secondary treatment system, but this facility overloads and does not meet NPDES permit conditions. Furthermore, through ineffective operation the waste stabilization lagoons at the town of Trappe have contributed to the closure of La Trappe Creek.

The water quality report for Maryland2/ stated that through upgrading of a single STP, 3,600 acres of shellfish waters in the lower Choptank were opened in September 1974. It was also stated that upgrading of the Cambridge STP to secondary treatment and improvements in the sewer collection system would drastically improve water quality in the Choptank River downstream from the STP.

It has been suggested that although upgraded treatment should lessen bacteriological counts, increased nutrient levels in the receiving waters may result in other kinds of problems, such as algal blooms, for these waters.

Poultry, seafood and other types of food processing, and canneries are the major industries in this area. Many of these industries have their own treatment systems or pre-treat waters before discharge into municipal systems. A few industries discharge directly into municipal systems, contributing to overloads in the system.

The heaviest concentration of runoff problems is found in the watershed above Cambridge. The problem exists mainly in localized and inaccessible rural areas, making assessment and control difficult. According to the

I/ "Water Quality Management Plan, Basin Plans," (Choptank River), Maryland Department of Natural Resources, 1976.

2/ "Maryland Water Quality," pursuant to Sec. 305(b), P.L. 92-500, State of Maryland, 1976. 
Maryland State water quality report the problems are not easily correctible, since many animals are present in such locations. It should also be noted that large populations of waterfowl in the Basin contribute to the agricultural waste in these waters. The Canada goose wintering population in Maryland has increased since the $1940^{\prime}$ 's due to a changeover to corn and soybean agriculture. $\underline{1}$

The Maryland Environmental Health Administration (EHA) and the Department of Natural Resources disagree with the Food and Drug Administration's (FDA) coliform criterion, most probable number (MPN) of 70 per $100 \mathrm{ml}$. The EHA considered as ideal the fecal coliform MPN of three per $100 \mathrm{ml}$. or less as a guideline for approved areas. It has also been suggested that the water criteria for the market standard are unenforceable (not more than 10 percent of samples can exceed total coliform MPN of 230 per $100 \mathrm{ml}$.) EHA is also responsible for classifying the shellfish waters. The shellfish waters seem to be adequately classified, but frequent opening and closure are of concern to the Food and Drug Administration.

To conserve the shellfish resource, methods of relaying and depuration are used in harvesting in the Choptank River and in Broad Creek. In 1975 about 165,540 bushels of -oysters were relayed from the Choptank and 9,115 from Broad Creek. This was done during the closed season and mostly by the State agencies rather than by individuals.

Recreational boating is heavy in Maryland. On the waterways themselves the use of thousands of boats for recreational purposes and as weekend residences results in overboard dumping of sanitary and other wastes. There is a lack of enforcement for the control of waterway pollution in Maryland, as well as insufficient patrolling to monitor boating waste violations.

There have been frequent violations by boats in the Choptank Basin waters. The closures in these areas are usually a result of boating wastes combined with other watershed pollution sources described earlier. Maryland is presently trying to provide for "no discharge area" permits in order to protect these waters.

In the Choptank Basin area, maintenance dredging is necessary for all the waterways used for recreational boating and commercial shipping. Agricultural drainage systems built for farm production purposes also require dredging activities. The extreme upper Choptank River drainage in Maryland and Delaware will be channelized and modified under the Federal-State-County Soil Conservation District plan developed in Maryland. Most of this channe1ization will be done in Delaware. Activities will include drainage projects as well as the building of a dam and a lake in the upper reaches.

The main concern here is that this project could result in increased

1/ "National Estuarine Study," U.S. Department of the Interior, Fish and Wildlife Service, 1970. 
land runoff, increased organic loadings, and higher solids and turbidity levels in the upper Choptank River area. Although this area is a significant distance from the shellfish waters, the cumulative effects on the downstream area are not known.

The Army Corps of Engineers is responsible for carrying out these projects, and cooperates with environmental agencies to the extent that it applies the recent informal Dredge-Spoil Disposal Criteria set up by Federal and State agencies at a conference in Maryland.

Sedimentation due to land use and shoreline erosion is a recognized problem in Maryland. The Maryland Soil Conservation Service is involved in soil erosion and conservation attempts in every county, and most incorporated municipalities in the Choptank Basin have adopted sediment and erosion control ordinances. I/ Cooperation between the county planning and zoning departments and the Local Soil Conservation Districts is ongoing, but most counties are understaffed.

Minor kills of soft-shell clams as a result of flooding by hurricane Agnes occured in the Choptank area. According to a study done for the Baltimore District Corps of Engineers, in Maryland, over 90 percent of the soft-shell clam mortalities resulted from the combined stresses of low salinity and high water temperatures. $\underline{2}$

The activities associated with recreational boating, channel dredging, and low-level urbanization tend to intensify the significant impacts of agricultural runoff, resulting in marginal water and resource quality. However, the frequent shifts between open and closed status and the planned upgraded treatment suggest the area's potential for water quality improvement.

1/ "Choptank River Basin Water Quality Management Plan," Maryland State Department of Natural Resources, November 3, 1976.

$2 /$ "Impact of Tropical Storm Agnes on Chesapeake Bay," Department of the Army, Corps of Engineers, March 1975. 


\section{Virginia}

From conversations with Virginia control officials, it appears that despite efforts toward improved water quality, Virginia's shellfish industry may experience setbacks if Federal and State disagreements over shellfish management policies remain unresolved.

Surf clams and oysters (Crassostrea virginica) comprise the major portion of shellfish produced in Virginia's waters. In 1974, 58.2 million pounds of clams brought a dockside value of $\$ 6.8$ million, and 6.6 million pounds of oysters brought into Virginia's economy $\$ 4.9$ million (dockside value). Employment of an estimated 36,000 persons is provided for by this annual yield. In $1974,293,000$ persons were involved in recreational harvesting. $1 /$

In 1974, public grounds totaled 240,000 acres and leased acreage totaled 100,230 acres. A total of 107,156 acres of shellfish growing waters were condemned through 1972. The State Water Control Board (SWCB) assisted the Bureau of Shellfish Sanitation (Virginia Department of Health) in reopening 79,338 acres during 1972, 1973, and 1974 as a result of efforts directed toward the control of animal wastes. However, in June 1975, FDA published the proposed rules for the National Shellfish Safety Program, and in anticipation of the enforcement of the rules, the Virginia Bureau elected to utilize more stringent criteria in its evaluation of classified growing waters. This, together with subsequent water quality problems encountered, resulted in 237,426 acres closed as of January 1, 1976.

State agency officials do not anticipate additional closures in the near future and hope that pollution abatement projects called for in the National Pollutant Discharge Elimination System (NPDES) that are under construction now by municipalities, will solve most problems in the next five to eight years.1/

There is, however, a great deal of concern as to whether trends in reopenings can be established. Reasons for this include the questionable attainability of the standards, and the emphasis that is being placed on establishment of buffer zones. Buffer zones are areas closed to shellfish harvesting as a precaution against breakdown or failure of nearby sewage treatment plants. It has been suggested by some state officials that use of alarm systems and fail-safe features in treatment plants, rather than continued use of buffer zones, could reopen growing areas where the present water quality is adequate to meet the existing harvesting standards. Although the Virginia Shellfish Sanitation Program is moving toward increased sanitary control of growing water areas, there are differences of opinion regarding the definition of animal wastes as a health hazard. The Bureau of Shellfish Sanitation contends that animal waste does not constitute a public health hazard, whereas the Virginia Water Control Board contends it is a

\footnotetext{
1/ "1976 Water Quality Inventory," pursuant to Sec. 305(b) of P.L. 92-500, Virginia State Water Control Board, April 1976.
} 
potential hazard. There also appear to be inconsistencies involved in the criteria for classification on growing waters--some areas are closed solely on the basis of high bacteriological counts, while others with high counts remain open. Water quality problems facing State agencies are several, and their current status is summarized in the following paragraphs.

Both Federal and State agencies recognize and acknowledge the problem of chlorination effects on water quality--a chlorine level of $0.05 \mathrm{ppm}$ can be fatal to oyster larvae, whereas levels above that are required for effective disinfection of sewage waste. I/ This is particularly significant considering the heavy dosages administered to treat combined sewer overflow. There is no attempt to reduce chlorine levels for treatment of light sewage loads and, further, Virginia has no water quality standard for chlorine (i.e., maximum levels).

An intrastate conflict exists between public health interests who claim that levels must be high to protect health, and water quality interests who favor lower, more enforceable levels to protect the resource. It has been recommended that the Virginia State Water Control Board closely watch ongoing studies concerning use of ozone treatment of sewage and ultraviolet irradiation as alternatives to chlorination. 2 /

Though many studies have been conducted of the effects on fish and shellfish due to heavy metals in water, action levels (i.e., established limits beyond which a public health hazard is present) have not been established by either State or Federal agencies. A statement was made that no real progress is being accomplished, even though more data are being collected, because toxicological evidence as to the body burden is unavailable. One report issued by VIMS 3 / pointed out that.

"The heavy metals, cadmium, copper and zinc--have been shown to be concentrated (in shellfish) four to five orders of magnitude above that of the surrounding water (Kopfler and Mayer, 1969). Aside from the obvious public health...aspects...the phenomenon may be used to detect pollution sources (Schuster and Pringle, 1969)"

and

"...concentrations of heavy metals...in oysters are a function of not only source but also the animal's position in the estuary. The future use of concentration ratios is suggested which allows:

1/ Private communication from a source at Virginia Institute of Marine Science.

2/ Kelly, C.B., "The Toxicity of Chlorinated Waste Effluents to Fish and Considerations of Alternative Processes for the Disinfection of Waste Effluents," Virginia State Water Control Board, June 1974.

3/ Huggett, R.J., M.E. Bender, and H.D. Stone, "Utilizing metal Concentration Relationships in the Eastern Oyster (Crassostrea virginica) to Detect Heavy Metal Pollution," Water Research Vol. 7, PP. 451-460, 1973. 
(1) an indication whether metal concentrations in organisms are from natural or manmade sources;

(2) recognition of problem areas before they reach nuisance levels;

(3) prediction, with some certainty, of areas which would be adversely affected by unnatural additions of metals; and

(4) prediction of areas which could best tolerate unnatural additions of metals."

The Virginia State Water Control Board indicates that as of December 1, 1975, the animal waste program issued 381 State "No-Discharge" Certificates to operations in which animal wastes were handled in a liquid or semi-liquid form. This assured that the wastes from 14 percent of the total number of pigs in the State, 11 percent of the dairy cattle, and less than one-half percent of the beef cattle and one-half percent of the poultry are no longer a threat to water quality. The program resulted in preventing $61,000 \mathrm{lb} . /$ day of $\mathrm{BOD}$ and $277,000 \mathrm{lb}$./day of total solids from entering State waters. I/ The State requires that all animal producers handling liquid waste must have a discharge certificate.

State officials noted that there is a lack of federally supported research in shellfish sanitation and that some of the subjects needing investigation in terms of protection of growing areas were: effects of wildlife, boat discharges, non point sources, effects of herbicides on lower animal life, and determination of body burden for metals. In Lynhaven Bay, for example, much progress has been made toward alleviating point source problems, but non point source pollution continues to be an unsolvable problem.

Virginia suffers from lack of manpower, as do Federal agencies having jurisdiction over water quality. There is a backlog of 2000 violations that are going uncorrected due to manpower limitations. In addition, illegal harvesting is a problem, partly because patrol of closed areas is insufficient.

Cooperation between State, industry, and FDA will suffer significant setbacks unless certain doubts and disagreements are more adequately addressed :

- There is a need, if indeed the fecal and/or coliform standard is realistic, for bacterial standards to be substantiated to State satisfaction.

1/ "1976 Water Quality Inventory," pursuant to Sec. 305(b) P.L. 92-500, Virginia State Water Control Board, April 1976 
- The question of what constitutes a public health hazard, in terms of coliform counts and the presence of animal wastes, needs to be investigated and settled.

o The extent to which discretion will be allowed the State in classifying growing areas needs to be determined.

- The conflict between public health and water quality interests in terms of effective disinfection of waste versus chlorine-related resource mortalities needs to be resolved.

Funding by State and Federal agencies should allow for (1) accelerated efforts to test and demonstrate alternatives to chlorine treatment, (2) further investigation of the effects of herbicides on lower forms of animal life, and (3) the development of a body of knowledge that pulls together all resources (past research results, etc.) to determine body burden for heavy metals. 
6. Mississippi River Delta, Louisiana

The Louisiana coastline is a maze of shallow estuarine bayous, lakes, and marshes formed and maintained by the meanderings of the Mississippi River. Following shrimp and menhaden, the oyster fishery is the third largest fishery in Louisiana, with a 1975 harvest valued at over seven million dollars. 1/ This was about 15 percent of national oyster harvest. 2 / There are approximately 460,000 acres of public oyster seed waters in the State containing natural oyster reefs that are augmented by planted cultch materials. Roughly 180,000 acres of wetlands are leased to individuals as private oyster beds. $\underline{3} /$

Major problems to molluscan shellfishes have geen caused by flood control and channelization of the Mississippi River, 4 flooding of the river,, and construction and presence of numerous shipping channels, boat canals, and oil pipelines traversing the State's coastal lakes, swamps and bayous.6/

The Louisiana estuarine zone experiences almost all the problems typical of other estuarine areas in the Nation. Population increases, urban and industrial pollution, agricultural runoff, exploitation of oil resources, and commercial shipping have impacted its estuaries. Except in areas in and adjacent to main channels of the Mississippi River and around urban areas such as New Orleans, resources problems are not magnifying. There is, however, a potential for significant losses of resources in the near future.

Oysters and other estuarine biota are greatly dependent on fresh water. It carries nutrients from the land and helps to maintain a salinity range in which, the organisms are most productive. The numerous flood control structures, such as levees built along the Mississippi, direct river water further out into the Gulf of Mexico, rather than over and through the bayous.

1/ "Louisiana Landings, Annual Summary 1975," Current Fisheries Statistics, No. 6922 , U.S. Department of Commerce, National Marine Fisheries Service, October 1976.

2/ "Summary of Oyster Landings, 1929-1975," Oyster Industry Report.

3/ "Unique Ecological Features of the Louisiana Coast," Louisiana State Planning office, June 1976.

4/ "Louisiana Government and the Coastal Zone--1972," Louisiana Advisory Commission on Coastal and Marine Resources, March 1972.

5/ V. Casper, FDA Dallas, personal communications.

6/ Schafer, H.E., Jr., "The Louisiana Oyster Fishery," in Proceedings of a Public Symposium on the Oyster Fisheries of the Gulf States, Gulf Coast Research Laboratories, Biloxi, Mississippi, October 1972. 
Because of this redirected flow, higher salinity water intrudes further into the bayous each year. Accordingly, estuarine organisms move further inland where they are closer to urban and industrial pollution sources. The problem is compounded by construction of canals and pipelines through the bayous making unobstructed channels for fresh water to flow through the estuarines and into the Gulf with minimal mixing. $1 / 2$ It has been estimated that salt water intrusion has reduced the effectiveness of oyster seed grounds in southeastern Louisiana by over 60 percent.

Nutrients trapped behind dams further reduce estuarine production. A classical example is the Nile River Delta and estuary in Egypt. The Aswan Dam blocked flow from the Nile Drainage Basin into the Delta and a once productive fishery in the area has been severely depleted, quite probably due to nutrient entrapment. $\underline{4}$

Flooding in an unaltered river basin can be beneficial to the basin and its estuary. Flooding has a scouring effect--clearing the river and estuary of accumulated sediments and debris, depositing them to create new coastal land, and thus enlarging the estuary. In addition, debris carried from a watershed provides nutrients and stored energy (in the form of detritus) for estuarine urganisms. $5 / 6 /$ Under natural conditions the destructive effects of even severe floods disappear in a short time, resulting often in a more productive river basin and estuary.

In an altered river basin such as the Mississippi Basin, flooding can be a severe problem, especially to estuarine biota such as shellfish. Because shellfish beds have migrated inland in response to high salinity, $6 /$ there is a smaller buffer zone of brackish water between the shellfish and freshwater. When flooding occurs, shellfish are surrounded by essentially fresh water rather than the low salinity brackish water to which they are accustomed. Though shellfish easily withstand brief exposure to fresh water by closing their shells, flood control structures increase flooding periods, prolonging exposure of shellfish to fresh water and potential mortality

The lower Mississippi River is heavily contaminated with agricultural, shipping, urban, and industrial pollutants from New Orleans and Baton Rouge. If Floodwaters carrying these substances can contaminate or poison

1/6/ "Louisiana Government and the Coastal Zone--1972," Louisiana Advisory Commission on Coastal and Marine Resources, March 1972.

2/ Schafer, H.E., Jr., "The Louisiana Oyster Fishery," in Proceedings of a Public Symposium on the Oyster Fisheries of the Gulf States, Gulf Coast Research Laboratories, Biloxi, Mississippi, October 1972.

3/ "Cooperative Gulf of Mexico Estuarine Inventory and Study," Louisiana Wild1ife and Fisheries Commission, 1971.

4/5/ Champ, M.A., personal communication, Department of Biology, American University, Washington, D.C.

7/ "National Water Quality Inventory, 1974 Report to Congress," EPA-440/9-74-001, U.S. Environmental Protection Agency, 1974. 
shellfish. Unfortunately, a great deal of their pollution is from non-point sources and therefore, difficult to control.

It should be added, beneficial effects would take place by adding Mississippi River water to the estuary. Releases of river water through the Bonne Carre spillway into Lake Pontchartrain reputedly benefit oysters by eliminating drills and other oyster pests which are intolerant of fresh water.

Construction and maintenance of shipping channels, canals and oil pipelines promote additional resouce problems. The Mississippi River-Gulf Outlet canal, constructed by the Army Corps of Engineers, emphasizes the apparent low priority given shellfishing interests (and concerns for the coastal zone environment in general) where interests of heavy industry, waterways, and navigation are involved.

The Outlet is currently functional, but not fully completed. It is a seaway canal 36 feet deep and 500 feet wide extending 76 miles from New Orleans into the Gulf of Mexico in an uninterrupted straight line. It is intended to provide improved shipping access to New Orleans and the Mississippi River, bypassing the river Delta. The estimated total construction cost of the canal is over $\$ 350$ million.1/

The Outlet cuts a path through Plaquemines and St. Bernard Parishes which have some of the most important oyster beds in the state. The 450,000 acres of public oyster seed waters in this area supply approximately 80 percent of the oysters transplanted to privately leased oyster beds in the State's coastal zone.2/ The combined harvest from the public seed waters and privately leased oyster beds in this area is roughly 55 percent of the State total or approximately 8 percent of the national harvest $3 /$ Currently, public seed waters, although experiencing some problems with high salinity intrusion, have remained relatively clean. Privately leased oyster beds, further inland and closer to New Orleans, have not been as fortunate, and occasional closings have occurred. $4 \underline{5}^{\prime}$

1/ "1973 Annual Report of the Chief of Engineers on Civil Works Activities," G.P.O. No. 008-022-00088, Department of the Army, Corps of Engineers, 1973.

2/ "Unique Ecological Features of the Louisiana Coast," Louisiana State Planning office, June 1976.

3/ "Louisiana Landings, Annual Summary 1975," Current Fisheries Statistics, No. 6922, U.S. Department of Commerce, National Marine Fisheries Service, October 1976.

4/ "Louisiana Shellfish Sanitation Program Appraisa1, July 1, 1975 .June 30, 1976," U.S. Department of Health, Education, and Welfare, Food and Drug Administration, 1976.

5/ Schafer, H.E., Jr., "The Louisiana Oyster Fishery," in Proceedings of a Public Symposium on the Oyster Fisheries of the Gulf States, Gulf Coast Research Laboratories, Biloxi, Mississippi, October 1972. 
Increased turbidity and silt load as a result of dredging and spoil disposal during construction of the canal are localized, therefore, not an immediate problem for the shellfisheries. Maintenance dredging of the canal, however, will probably prevent recovery of productive shellfish populations. Moreover, the canal and maintenance spoil could considerably alter water flow patterns and result in increased saltwater intrusion. $1 / 2 /$ Heavy use of the canal is likely to introduce significant shipping-related pollution which, through tidal action and long-shore currents may spread over much of the shellfish waters in the area. Finally, the canal provides a direct path for severely polluted water from New Orleans to the shellfish, essentially eliminating filtration normally provided by bayous and marshes.

Although less critical to the discussion of Louisiana's shellfish waters, there are other pollution sources worthy of mention.

Urban and industrial pollutants, particularly from New Orleans, have caused some closures in privately leased oyster beds. For the most part, however, pollutants either flow down the Mississippi River channel into the Gulf, thereby bypassing major shellfish areas, or natural filtration in the bayous removes the polluants before they reach major shellfish areas.

Movement of human population closer to the shellfish waters is causing some problems due to inadequate waste treatment facilities. High water tables are partly to blame. In addition, population influxes are followed by the construction of levees for hurricane protection, and canals for boat travel, $3 /$ all of which remove or dislocate habitat.

Exploitation of oil in Louisiana's estuarine zone carries with it the danger of oil well leaks and spills. Unfortunately, such events occur in proximity to the State's major shellfish waters. Although there is evidence that oysters can recover from small oil spills, $3 /$ the effects of large spills are not as well understood.

Agricultural pollution is an increasing problem in the area. Farm runoff carries fertilizers, insecticides, silt, and wastes from cattle operations which raise coliform counts. The latter may result in closing of shellfish beds,, 1

The large volume of commercial shipping passing through Louisiana each year ( $\$ 2.8$ billion for New Orleans alone) $2 /$ also introduces an abundance of contaminants into the state's estuarine zones.

1f Schafer, H.E., Jr., "The Louisiana Oyster Fishery," in Proceedings of a Public Symposium on the Oyster Fisheries of the Gulf States, Gulf Coast Research Laboratories, Biloxi, Mississippi, October 1972.

2/ "Louisiana Government and the Coastal Zone--1972," Louisiana Advisory Commission on Coastal and Marine Resources, March 1972.

3/ St. Amant, L., Director, Louisiana Wildlife and Fisheries Service, personal communications. 
From 1971 to 1974, Louisiana increased the acreage open to shellfishing from about 1.5 million acres to slightly over 2 million acres. During the same period, however, closures increased for approximately 200,000 acres to almost 500,000 acres.ㅌ/ Between July 1975 and June 1976, estuarine areas in the State showed a generally improved water quality and there were no new closures. This is believed due to low stream flows in the Mississippi River during that period (22-year low) resulting in reduced transportation of contaminants into the estuaries. Most of the closed shellfish waters in the State adjoin the Mississippi River channel or large urban areas. There are also isolated closures in rural areas when sewage or animal wastes contaminate shellfish waters.르리

Fortunately, State and Federal agencies in Louisiana recognized many of the water quality problems mentioned in this study and are working on solutions to them. For instance, saltwater intrusion in the estuarine zone may be alleviated by installation of structures for transferring fresh, untreated water from the Mississippi River into the bayous. Because of contaminants in the river, shellfish grown in water transfer areas must, of course, be depurated before they are marketable. 4/ Unfortunately, most urban and industrial pollution is from nonpoint sources, thus solving Louisiana's water quality problems will be easy.

In the final analysis, the fate of Louisiana's coastal fisheries and shellfisheries will depend on whether the fishing industry with its annual harvest worth $\$ 70$ million, $\underline{5} /$ can compete with interest of heavy industries. Their annual production is in the billions of dollars and the maintenance and enhancement of the State's naturally renewing shellfish resources will be a battle not easily won.

1/ "National Shellfish Register of Classified Estuarine Waters, 1974," U.S. Environmental Protection Agency, December 1975.

2/ Casper, V., FDA Dallas, personal communications.

3/ "Louisiana Shellfish Sanitation Program Appraisal, July 1, 1975 June 30, 1976," U.S. Department of Hea1th, Education, and Welfare, Food and Drug Administration, 1976.

4/ Schafer, H.E., Jr., "The Louisiana Oyster Fishery," in Proceedings of a Public Symposium on the Oyster Fisheries of the Gulf States, Gulf Coast Research Laboratories, Biloxi, Mississippi, October 1972.

5/ "Louisiana Government and the Coasta1 Zone--1972," Louisiana Advisory Commission on Coastal and Marine Resources, March 1972. 


\section{Washington State}

The water quality and molluscan shellfish resource problems of the State of Washington differ from those found in other key states. In Washington such problems are of comparatively low intensity, and among management agencies there is a demonstrated awareness of existing conflicts concerning estuarine uses and the future implications of these conflicts. Adequate waste treatment plants in this State are being constructed or updated, and nonpoint source pollution is not as servere as in other areas. In general, water quality in Washington's estuarine areas has not yet suffered a high degree of degradation, and these areas deserve close observation. In the future, they may serve as examples of effective resource management techniques. Table A-I shows several parameters of water quality in four estuarine areas, and indicates the relatively high quality of the State's waters, as well as improvement in some previously degraded areas.

Growing water conditions for oysters and clams in the State are now considered good for the following reasons:

o Abundance and diversity of water resources, both fresh water and marine.

o High assimilative capacities for pollution.

- Abundant and diversified shellfish resources in several estuarine areas.

o No dense industrial centers along the shores.

- Relatively high pollution control efforts by Federal and State agencies under existing laws and guidelines.

o No severe shellfish-related water quality problems at the present time.

o High degree of citizen interest and support for environmental quality and pollution abatement efforts.

Were any of these conditions to deteriorate significantly, the effects on shellfish resources would be felt almost immediately.

Washington remains the only State to have received approval of its work plan under the Coastal Zone Management Act of 1972. Although there are conflicts among State and Federal agencies with respect to the management and utilization of coastal zone lands and resources, progress seems likely.

Washington was also one of the first states to gain approval of its National Pollutant Discharge Elimination System (NPDES) program under the Federal Water Pollution Control Act Amendments of 1972 (FWPCAA). According to information provided by the State's Department of Ecology, which administers the permit program, State water quality standards are being met 


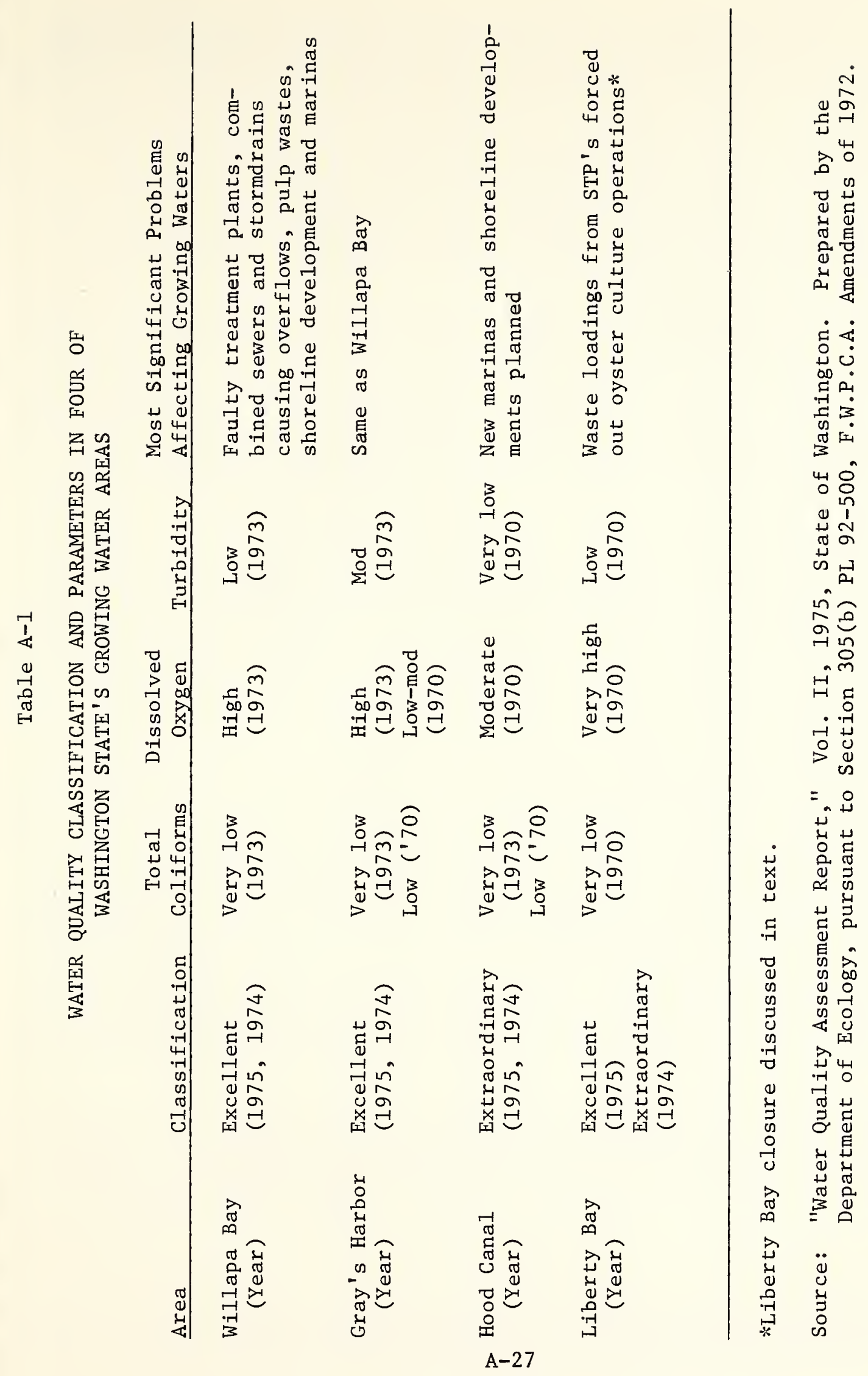


through the NPDES system: "The present permit system for point discharges appears to provide adequate water quality for shellfish protection." However, see the discussion of Liberty Bay, below and in Table A-1. Permittees are also required to have self-monitoring programs. In Washington, all the permits that have been applied for have been issued, including 475 NPDES permits that allow controlled discharges in or near molluscan shellfish waters. While most of the wastewater discharges are disinfected with chlorine, a few plants are considering a change to ultraviolet irradiation or ozone treatment. Of the dischargers not presently conforming with effluent limitation guidelines, most or all are scheduled to meet requirements for secondary treatment by 1980 .

Some of Washingtons estuaries have been impacted by sedimentation from logging and from poor land use, which contributes to the need for dredging. Dredging and filling activities carried out in or near estuarine waters are closely monitored by State and Federal officials who coordinate reviews with the Army Corps of Engineers. Channel dredging in Willapa Bay and Grays Harbor, and hydraulic dredge harvesting of geoduck clams in Puget Sound were identified as potential problems, but the degree of significance was not specified.

The State does not presently require pump-out facilities for marinas, and the overboard discharge of domestic sewage from recreational boats is seen as a contributing factor to shellfish related water quality problems. However, guidelines have been adopted that may require pump-out facilities at new or expanding marinas. Violations of shellfish water quality standards due to commercial and military vessels that discharge their wastes overboard are also seen as a problem.

Because nonpoint source discharges could still be a major cause of problems for water quality, the State has also taken steps to implement its areawide waste treatment planning under Section 208, FWPCAA. Regional sewage treatment plants are planned for Willapa Bay and Liberty Bay in Puget Sound. The Environmental Protection Agency recently investigated the mortality of oyster larvae reared in a hatchery in Liberty Bay, suspecting heavy metal discharges as the destructive agent. More serious problems were discovered relating to violations of waste discharge permits or dischargers having no. permit at all.1/ It is significant that a Federal agency looked into the problem, although results were somewhat inconclusive. The oyster hatchery has since moved elsewhere, and it remains to be seen what beneficial effects the planned relocation of outfalls outside the Bay will have on the water quality of Liberty Bay.

Willapa Bay, located on the Pacific Coast, is bounded by a well developed peninsula and by marshes, grasslands, and uplands in the east, north, and south. It supports an extensive fishery and has a tremendous potential

1/ "Chemical and Biological Survey of Liberty Bay, Washington," EPA-910/9-76-029, U.S. Environmental Protection Agency, September 1976. 
for additional shellfish culture. $1 /$ However, in discussions with State fisheries personnel, it was suggested that if additional culture areas were made available for leasing, it was doubtful that watermen could take advantage of the availability because market demands for the product are current1y low.

The large Pacific or Japanese oyster was imported from Japan in 1905 for commercial growing purposes, and has provided a vast resource of large oysters. Large oysters are otherwise available only from East Coast markets. Attempts to culture the Eastern U.S. oyster in West Coast estuaries have been unsuccessfu1. The Pacific oyster requires specific conditions for spawning available in only a few of Washington's waters, including Willapa Bay. 2 Intertidal hardshell clams, non-molluscan shellfish (shrimp and crabs), and commercial and sport finfish are also abundant in the Bay.

The attractive features that make Willapa a valuable natural resource can a]so lead to its downfall. Expanding human population, summer residential development, agricltural development, and industrial development adjacent to Willapa Bay are affecting the environment on which fish and wildlife resources depend. The few streams entering Willapa Bay are sources of fresh water vital to agriculture, industry, and aquatic life in the estuary. The Bay and adjacent ocean absorb the various wastes and other discharges that accumulate in the streams from towns, industry, agriculture, summer recreational communities, and other land use practices throughout the basin. The inlet from the ocean affords easy access for marine transportation. 1 f

The waters of Willapa Bay are well circulated except at the head of the bay, where more flushing is thought to be needed; they transport food to natural communities and remove their wastes, maintain high levels of dissolved oxygen, and aid dispersal of shellfish eggs and larvae. The watershed of about 900 square miles is devoted primarily to agriculture and forestry.

There are four municipal waste dischargers averaging 330,000 gallons per day on the lower reaches of the Willapa River. 2/ High stream runoff and combined waste water/sewage collection systems result in poorly treated discharges, or even raw discharges bypassing the treatment facilities. Elevated coliform counts during these periods result in shellfish area closures several times each year. During these periods, shellfish harvesting close to the mouth of the river is restricted or prohibited. Regional waste treatment facilities should alleviate some of the more pressing water quality problems in the eastern areas of the bay.

1/ "National Estuarine Study," U.S. Department of the Interior, Fish and Wildlife Service, January 1970

2/ Washington Marine Atlas, State of Washington Department of Natural Resources, July 1974. 
Four industrial dischargers are also located near the mouth of Willapa Bay on the River--two associated with forest products companies, and two with oyster processing. Approximately 750,000 gallons per day (GPD) are discharged by the forest products companies, and 85,000 GPD by the oyster processing plants. If Pulp wastes causing elevated coliform counts are still a problem in the Bay, but the quantities have been reduced significantly since enactment of P.L. 92-500.

The western portion of the State experiences a very high seasonal rainfall. During the rainy season (average monthly rainfall during the period October through December is eight inches), drainage basin flows are high. The primary runoff period (rain and snow melt) is November through April, which coincides approximately with shellfish harvesting season. Flows into the treatment plants originating from nearby areas often exceed waste water treatment capacities. Large quantities of coliform bacteria from forest, agricultural, and urban sources find their way to the Bay system during this season, and most avoid passing through a treatment facility. Excessive fresh water flows into the Bay lower the bacteria mortality rate usually associated with saline water, thereby periodically closing areas to shellfishing during the harvest season.

The U.S. Army Corps of Engineers has performed maintenance dredging for river channels, Bay shipping lanes, and marinas in the Willapa Bay and Harbor areas since the $1890^{\prime} \mathrm{s}$. The Bay channel bisects productive shellfish culturing and producing areas westward of the mouth of Willapa River. Maintenance dredging for deep draft navigation in Willapa Bay will terminate in 1977. Between 1975 and 1977, channels have been maintained to accommodate shipping traffic. The following is quoted from the Final Environmental Impact Statement on the Willapa River and Harbor Navigation Project, prepared by the Corps in January 1976: "Impacts on water quality will be limited to the time of dredging and shortly thereafter through 1977. These impacts will occur annually during late fall and winter months when (the bay channels are dredged)...total duration of these impacts will be about 60 days per year." It should be pointed out again that shellfish harvesting in the immediate area also occurs during "late fall and winter months." Concern for the buildup of silt on the oyster beds, which could cause permanent damage by smothering the oysters, was responded to with a pledge of further observations during dredging activities to determine if this is, in fact, the case.

Between 1964 and 1974 approximately 1.5 million cubic yards of dredged material were disposed of within the Bay's estuarine areas. Annual maintenance of the inner Bay channel requires removal of 130,000 cubic yards of material annually. Dredged material from the present activities will be placed at one of two sites covering about 20 acres within the estuary but away from productive shellfish beds.

\footnotetext{
1/ Washington Marine Atlas, State of Washington Department of Natural Resources, July 1974.

2/ "Water quality Assessment Report (305(b))," State of Washington Department of Ecology, June 1975.
} 
Recent available information on resuspension of materials due to dredging and its effects on benthic organisms is minimal; hydrographic characteristics play an important role in the movement of these materials throughout the bay system, and should be carefully researched.

Other, less urgent problems relate to development of the estuarine shoreline. As migration to the shoreline environment continues, housing and attendant activities will contribute to the diminshment of the Bay's estuarine productivity. Methods used for pollution reduction and abatement for continued estuarine resource protection should be monitored closely in this area. The water quality is still superior and pollution levels are presently 1ow. There is no guarantee, however, that this situation will continue in the future.

Nonpoint source pollution mechanisms in urban and agricultural runoff, sediment transport, and the large category of "unknown" sources of pollution have not yet been thoroughly studied. Contamination from these sources will continue to affect Willapa Bay and shellfish growing waters elsewhere in the nation, and it may be years before any significant action is taken. Federal and State agency priorities, financial constraints, and manpower limitations are some of the reasons for this.

Although Washington has many water problems in common with those of other shellfish producing states, though to a lesser degree, it also has features that differ, such as the location of the State, its water resources, State efforts to minimize unnecessary Federal intervention, and success in carrying out State responsibilities established under Federal laws. It will be interesting to note the progress, as well as the setbacks, in implementing government programs. Future trends in water quality, molluscan shellfish resources, and related research should be monitored. If the State can solve its more pressing problems and retain a relatively thriving resource, it may serve as an example to other areas. If it cannot, other states with similar but more intensive water quality problems should not expect any greater success in terms of improved water quality or protection of shellfish resources. 


\section{Apalachicola Bay, Florida}

Apalachicola Bay is the largest producer of shellfish in the State of Florida. It was chosen as a case study because it exhibited a range of problems associated with Federal progrm activities. The bay is not yet significantly degraded, but the potential for degradation is high should its relatively minor problems be allowed to increase in magnitude. There has been limited Federal action that would mitigate existing problems concerning shellfish water quality.

Apalachicola Bay includes a series of lagoons and an estuary located behind barrier islands and a reef on the northeastern Gulf Coast of the Florida Panhandle. The bay is about 36 miles long and varies in width from one to 14 miles. Total area of the bay is approximatelv 180 sanare miles. The bay is relatively shallow, averaging about 5 feet in depth. Maximum depth is 32 feet at one of the passes from the Gulf. It is estimated that 46,000 acres of the bay (approximately 40\%) are suitable for growing oysters, although only 5-6,000 acres currently have commercially valuable oyster bars. 1 /

Apalachicola Bay is the only Florida Bay into which a large river (Apalachicola River) drains. The river system includes an area over 19,000 square miles and is composed of four major rivers and numerous creeks, streams, and marshes. The bay has historically provided ideal oystering and does so today. The reefs provide the major employment for the people of Franklin County and especially for those living in the seacoast villages bordering the bay.1/ An economic survey in 1965 showed that there were 1,561 people employed full-time by the fishing industry and 1,199 people engaged in other occupations.2/ In 1970, the local oyster industry employed 471 tongers, 519 shuckers and 94 housemen and skimboard operators. Total employment in the industry was 1,084 out of a total labor force of $2500 . \underline{I} /$

The shallow bars of the bay are ideal for oysters in terms of tidal exchange, salinities, and a lack of heavy urbanization in the immediate vicinity. In 1970, approximately 70 percent of the oyster meats produced in the state were harvested from the bay, and the 1975 harvest was nearly 90 percent of the state total. Remoteness of the shellfish beds from heavily urbanized areas has helped to protect the resource from deterioration due to poor water quality.

The sanitary lines surrounding the mouth of Apalachicola River have not changed in many years. A buffer zone consisting of a "Conditionally Approved Area" surrounding the Bay closure line is periodically closed to shellfishing when waste loadings pose a health hazard. The remainder of the Bay is

presently open.

1/ Rockwood, C.E., et al, "A Management Program for the Oyster Resource in Apalachicola Bay, Florida," Florida State University, Tallahassee, 1973.

2/ Colberg, M.R. and D.M. Windham, "The Oyster Based Economy of Franklin County Florida," U.S. Department of Health, Education, and Welfare, July 1965 . 
The major problems affecting Florida's oyster production are pollution and disease. Pollution, however, is thought to be the greatest threat to the industry. Major producing areas have already been lost and others are currently threatened because of pollution. Although a lesser problem, fungal diseases are capable of destroying oyster beds almost overnight. Furthermore, oysters living in polluted areas are apparently weakened and become more susceptible to disease. $1 /$

It is apparent that Florida's shellfish industry is dependent on the preservation of environmental quality in the Apalachicola River watershed. Problem sources of the watershed include: point and nonpoint discharges, urbanization, dredging and filling, boating and shipping, interstate pollution, conflicts among Federal responsibilities and programs, and synergistic or cumulative impacts.

In considering Federal permit activities, a major workload requirement of the Environmental Assessment Branch of the National Marine Fisheries Service (NMFS) in Panama City, Florida, is to review Corps of Engineers dredging and filling permits pursuant to provisions of the Fish and Wildlife Coordination Act. NMFS receives literally hundreds of permit applications each month, and is charged with commenting on their respective impacts upon marine resources and the potential consequences of habitat losses. Constraints of time, personnel, and financial resources allow NMFS to make site investigations only for "major operations." Other sites go unvisited, and EPA's NPDES permit applications are not reviewed. $2 /$

While there is a demonstrated need to respond to alteration projects in the coastal zone, the coordination of activities by NMFS and other Federal agencies, for other than those directly related to habitat protection, is limited. This appears to be the case with molluscan shellfish resources. A small NMFS laboratory in Panama City has numerous estuarine research projects underway, but none on molluscan shellfishes. Resources of concern in this report will benefit from increases in knowledge of estuarine systems however.

The distribution of Federal construction grants to municipalities in the South Atlantic-Gulf Region follows pathways similar to those in other regions. Heavily polluted waters are given more consideration and higher priority than waters with less pollution. Although Apalachicola Bay contains the most productive shellfish resources in Florida, the water quality problems are deemed insufficiently great to warrant significant Federal financial or program emphasis. Aged and faulty collection and treatment facilities have brought about plans to construct a new waste

لِ Joyce, A., Jr., "Florida's Oyster Industry and Current State Research Activities," in Proceeding of a Public Symposium on the Oyster Fisheries of the Gulf States, Biloxi, Mississippi, October 1972.

2/ Hall, J.R., "An Application of Coastal Resource Management and Conservation," National Marine Fisheries Service, Southeast Region, U.S. Department of Commerce, Panama City, Florida, 1976. 
treatment facility in the town of Apalachicola. However, both point and nonpoint sources of waste discharge remain a problem. Upstream sewage treatment plants discharge wastes treated mostly by primary techniques, and a large cattle ranch discharges substantial fecal coliform loading into tributaries and marshlands upstream of the bay. Additional water quality problems relate to the use of septic systems by towns and trailer parks, and attendant overflows or seepages.

Areawide waste treatment planning and nonpoint source waste discharges are dealt with under Section 208 of the Federal Water Pollution Control Act Amendments of 1972. The dividing line between point source discharges and nonpoint discharges appears to be a problem in one particular agricultural location near the Bay System. In early 1976, personnel from EPA Ecological Review Branch, Atlanta, Georgia, became involved with pollution problems associated with a 35,000-acre cattle ranch having about 10,000 head of cattle approximately 10 miles upstream from the mouth of the Apalachicola River. Drainage canals and natural streams on the ranch carry wastes from the ranch into the river. It is said to be one of the biggest ranches of its type in the South. With one animal sewage equivalent to about 16 humans, fecal loadings from the ranch would be roughly equivalent to a city of 100,000 persons. A regulation issued by EPA on July 10, 1976, covering intensive agricultural activities such as feedlots, did not cover agricultural operations associated with pastureland. Thus, the cattle ranch continues its activities beyond the reach of the NPDES permit system. According to EPA personnel, this regulation frustrated their efforts and the study of pollution problems was dropped. Agricultural and other nonpoint sources of pollution will also be dealt with under Section 208 planning. The possibility of designating Apalachicola Bay as a National Estuarine Sanctuary under Section 312 of the Federal Coastal Zone Management (CZM) Act is being investigated at the Florida Department of Natural Resources. An implemented CZM plan and a designated sanctuary would help to protect against incompatible upstream uses or developments.

An Army Corps of Engineers representative suggested that one of the Corps' biggest water resource planning problems was dealing with two or more states. This occurs whenever projects are proposed on the Upper Apalachicola or Chattahoochee Rivers. State boundaries of Florida, Georgia, and Alabama intersect on or near the impounded waters of these rivers behind Jim Woodruff Lock and Dam, a Corps project. Alternatively, states may have to coordinate activities with two or more Corps Districts. The State of Georgia has jurisdictions of the Mobile, Jacksonville, and Savannah Districts intersecting near the center of the State. It should be pointed out, however, that the Corps Districts are based on watersheds, and this could be beneficial for activities dealing with environmental matters.

With the exception of special studies, the Corps conducts few follow-up studies to determine nutrient and sediment accumulations behind dams.

Similarly, impacts associated with resuspension of those materials following storms and other phenomena are not regularly investigated. Instead, existing published studies are relied upon heavily in evaluations of post-project impacts. 
In addition to the problems described above, others of significance to Apalachicola Bay deserve mention:

o Present Enforcement of EPA regulations apply only to point-source discharges.

- EPA cannot always believe discharge monitoring data submitted by plant operators. For example, the same figures appear month after month.

o Training funds for plant operators are slow to materialize.

o Over-chlorination affects mortality of oyster larvae and spat oysters, whose tolerance for chlorine is small.

o Arbitrary enforcement of treatment plant violations leads to a lack of cooperation.

- Bypass of untreated municipal wastes into Apalachicola Bay occurs during malfunctions or heávy river runoff.

o Shellfish areas closed for many years because of pollution remain closed.

o Wetland destruction resulting from uncoordinated sequential marina development has occurred in estuarine areas.

- EPA can only recommend construction of pump-out facilities for old marinas and new marinas.

o Corps spoil disposal areas for dredging operations are not designated by the State.

Some of the problems and issues mentioned are unique to the bay system, and some are found throughout the Nation. Unique problems are: (1) the largest oyster producing area in the State has low Federal agency priority with respect to pollution abatement; (2) a drainage basin that touches three states with numerous and complex pollution problems is without a completed areawide plan (Section 208) or a river basin plan (Section 209) under serious consideration; and (3) despite efforts to upgrade wastewater treatment facilities through EPA grant monies, an upstream agricultural discharger could render the new Apalachicola treatment plant worthless in terms of reducing coliform loadings into the Bay.

A possible approach to preserving and enhancing the molluscan shellfish resource in the Apalachicola Bay System is given below. This approach is based on inputs from representatives of the various agencies visited in the course of this investigation. As always, limitations to funding and manpower play critical roles in program effectiveness.

1. Review agency priorities should emphasize research to protect estuarine habitat, water quality, and significant shellfish resources in the bay. 
2. Design and implement Section 208 areawide waste treatment plans, with emphasis on watershed management.

3. Develop methods to mitigate nonpoint source agricultural discharges.

4. Fund studies for determination and mitigation of the effect of man's activities on shellfish waters within the bay system.

5. Organize one or more teams of regional Federal agency personnel from among the various Federal departments and divisions involved, to better coordinate activities such as (a) laboratory and field research, (b) permits, (c) enforcement, (d) water resources, (e) dredging and filling, (f) environmental assessment (g) marine biology, (h) construction grants, and (i) coastal zone management. The team should include members of State conservation and planning agencies, fishery industry representatives, members of the scientific community, and concerned private citizens. The objective is to establish interchanges of ideas leading to management and rational resource allocations.

6. Produce frequent periodic reports noting progress made, areas of conflict, status of water quality and shellfish, and recommendations to maintain and improve resources. 
Appendix B

LEGISLATION

Note: Comments attached to the overview of the laws in this appendix are generally based on the law itself, its legislative history, and important court cases. Information on the application of the laws and on their effect may be found in the body of the report (Section VI). 


\section{CONTENTS}

1. Federal Water Pollution Control Act Amendments of 1972 . . . . . . . . . . . . . . . B-1

2. Section 404, Federal Water Pollution Control Act Amendments of 1972 . . . . . . . . . . . B-10

3. Rivers and Harbors Act of 1899 . . . . . . . . B-12

4. Marine Protection, Research, and Sanctuaries Act of 1972 $\mathrm{B}-15$

5. Fish and Wildlife Coordination Act of 1958 . . . . . B-21

6. Estuarine Areas Act . . . . . . . . . . . B-26

7. Commercial Fisheries Research and Development Act of 1964 . . . . . . . . . . . . . . B-28

8. Anadromous Fish Conservation Act . . . . . . . . B-29

9. Fishery Conservation and Management Act of 1976 . . . B-30

10. Water Resources Research Act of 1964 . . . . . . B-34

11. The Submerged Lands Act . . . . . . . . . B-35

12. Deepwater Port Act of 1974 . . . . . . . . . B-37

13. The National Environmental Policy Act of 1969 . . . . B-40

14. Coastal Zone Management Act of 1972 . . . . . . B-44

15. Coastal Zone Management Act Amendments of 1976 . . . B-46

16. Water Resources Planning Act . . . . . . . B-47 
1. Federal Water Pollution Control Act Amendments of 1972, P.L. 92-500, 33 U.S.C.A. Sec. 1251, et seq. (1976 Supp.)

\section{History}

The act was originally passed in 1948 and went through substantial amendment in 1956 and 1965. Prior to 1972, the act's focus was on ambient quality, and allowable discharges were related to the estimated assimilative capacity of the receiving body of water. Pre-1972 enforcement was found to be slow and cumbersome due to the requirements of conferences and waiting periods, judicial review of conference recommendations, and problems of measurement and causation. In 1960, the Supreme Court interpreted the provisions of the Refuse Act of 1899 to require that permits for discharges into navigable waters must be obtained from the Army Corps of Engineers. A 1970 Executive Order directed the Environmental Protection Agency to work with the Corps on the establishment of a national permit program. Although never fully implemented, the national program represented a major policy shift affecting all rather than only the worst polluters. The Refuse Act system was found to be deficient in that it applied only to industrial polluters and divided authority between two Federal agencies. The 1972 Amendments to this act greatly extended the discharge permit program.

\section{Purpose}

The purpose of this act is to restore and maintain the chemical, physical, and biological integrity of the Nation's waters. In order to achieve this purpose, the act declares a "no discharge" goal for 1985; an interim goal of water quality which "provides for the protection and propagation of fish, shellfish, and wildlife and provides for recreation in and on the water by 1983; a policy of prohibiting toxic pollutants; a policy that Federal assistance be provided for the construction of public waste treatment plants; and a policy that a major research and development effort be made to develop necessary technologies. Finally, the act declares a policy of leaving primary responsibility with the states so long as state laws and actions are consistent with the act. (Sec. 101).

\section{Implementation}

The act establishes a permit system. Lischarges are absolutely prohibited without a permit issued by EPA or the state (if the latter has an EPA approved and delegated program). Standards are based on guidelines to be promulgated in accordance with the "best practicable" (1977 requirement) or "best available" (1983 requirement) treatment technologies. (Sec. 301). (Some have termed the 1977 requirement an "end of the pipe" treatment; while the 1983 requirement would 
involve the entire manufacturing process).

1. Effluent Discharge Limitations

a. Existing privately-owned point sources are subject to the 1977 standards.

b. "New" point sources (or parts of a point source representing a substantial addition to an old source) are subject to the 1983 standards, including no discharge where feasible.

c. Toxic effluent discharges are controlled based on their "ambient effect," or judged individually in terms of ambient differences among locales.

d. Thermal discharges are subject to the same criteria as other pollutants unless a lower standard is sufficient to attain the water quality goals, or unless a higher standard is needed for the same purposes--this ties thermal discharge substantially into an "ambient effect" criterion.

e. Discharges of oil and "hazardous substances" (as designated by EPA) are prohibited.

f. Discharges into public treatment works which cannot be handled by them are prohibited unless pretreated.

g. Radiological, chemical, or biological warfare agents or high-level radioactive waste may not be discharged.

2. Water Quality Standards

a. EPA (or states) may impose stricter limitations where necessary to achieve the water quality goals of the act (protection and propagation of shellfish, inter alia, by 1983).

b. Water Quality criteria are to be published by EPA which, in part, provide information "on the factors necessary for the protection and propagation of shellfish..." (Sec. $304(\mathrm{a})(2)(B))$, for the assistance of dischargers in translating the requirements of the act. 
c. A national water quality inventory is to be published by EPA showing which waters are of unsatisfactory quality and making recommendations for improvement. 1 /

d. EPA is to set (or approve) water quality standards and plans consistent with the goals of the act, as a benchmark to determine whether the more stringent limitations ("a" above) need be applied. These standards are to be developed by taking standards of the previous water quality law and revising them as needed. The states are to submit these standards to EPA for review, possible further revision, and publication. (Sec. 303). This approach acts as a part of a nondegradation policy to see that water quality does not deteriorate below what it was under the prior law.

e. EPA is to publish the degree of effluent reduction attainable through the application of best practicable control technology available for classes and categories of privately-owned point sources. (Sec. $304(\mathrm{~b})(1))$.

f. EPA is to specify factors to be taken into account in determining required control measures for a given industrial category, including (among others):

- Cost of technology vs. effluent reduction benefits.

- Age of the equipment and facilities involved. (Sec. 304 (b) (2)).

g. EPA is to issue guidelines relating to discharges into the oceans which are to include: (Sec. 403(c)(1)).

- The effect of disposal of pollutants on human health or welfare, including but not limited to plankton, fish, shellfish, wildlife, shorelines, and beaches.

- The effect of disposal of pollutants on marine life including the transfer, concentration, and dispersal of pollutants or their byproducts through biological, physical, and chemical processes; changes in marine ecosystem diversity, productivity, and stability; and species and community population changes.

I/ "National Water Quality Inventory," EPA-440/9-75-014, U. S. Environmental Protection Agency, 1975. 
o The effect of disposal, or pollutants on aesthetic, recreation, and economic values.

- The persistence and permanence of the effects of disposal of pollutants.

- The effect of the disposal at varying rates, of particular volumes and concentrations of pollutants.

- Other possible locations and methods of disposal or recycling of pollutants including land-based alternatives.

o The effect on alternate uses of the oceans, such as mineral exploitation and scientific study.

Finally, where insufficient information exists on any proposed discharge to make a reasonable judgment as to these guidelines, no permit is to be issued. (Sec. 404 (c) (2)).

\section{Certificates and permits}

a. Certification by the state that the discharge is in conformity with effluent limitations under the act is necessary prior to issuance of an EPA permit.

(Sec. 401 (a) (1)).

b. Permits for discharging are issued by EPA requiring the discharge to conform to the effluent limitations. The state can take over this function if it submits and maintains an approved program. (Sec. 402).

c. Dredge/fill permits are to be issued by the Secretary of the Army subject to the scrutiny and veto of EPA. If

If See discussion of Army Corps of Engineers' responsibility under the Federal Water Pollution Control Act, the Rivers and Harbors Act, and the Marine Protection, Research, and Sanctuaries Act infra. 
4. Inspections

a. Owners/operators must monitor their discharges, and keep records, reporting the results of such monitoring to EPA (or the state) as required.

b. EPA has the right to enter and inspect the premises of any discharger.

5. EPA is to promulgate standards of performance for marine sanitation devices (such as holding tanks) to prevent the discharge of untreated or inadequate treated sewage. The standards are to reflect a consideration of the economic costs involved and the technology available. (Sec. 312).

6. Municipal Wastes: Treatment

a. Discharges from publicly owned treatment facilities are to be processed using the "best practicable" waste treatment technology (1983 requirement.) (Sec. 201(b)). The process contemplated by the act shall do the following: (Sec. 201 (d)).

o Recycle potential sewage pollutants.

o Dispose of nonrecycled pollutants so as to keep them confined and contained.

- Reclaim wastewater.

o Dispose of sludge in a manner that will not result in environmental hazards.

b. EPA is to publish information on the degree of effluent reduction attainable through the application of secondary treatment. (The 1977 requirement.) (Sec. $304(d)(2))$.

c. EPA is to publish information on alternative waste treatment management technique and available systems (Sec. $304(d)(2))$.

d. EPA is authorized to make grants for the construction of publicly owned treatment works (Sec. 201(g)).

e. For industrial users of publicly owned facilities, the act establishes pretreatment requirements and provides that fees be charged to industrial users in proportion to the user's wastewater load. (Sec. 204 (b)). 
a. The act seeks to deal with water quality planning and management through areawide or regional processes. (Sec. 208).

b. State Governors are to designate an areawide planning agency for areas which, because of "urban industrial concentrations or other factors" have difficult water quality control problems. (Sec. 208(a)).

c. For other parts of the state, local governments may join together to form a planning agency. Remaining parts of the state not in a planning agency will have their planning done by the state government. (Sec. 208(a)(6)).

d. Guidelines are to be published by EPA for assisting planners in identifying and evaluating nonpoint sources of pollutants. (Sec. $304(\mathrm{e})(1))$.

e. Information for planning agencies and others, is to be published on ways to control pollution from

- Agricultural, silvicultural, mining, and construction activities (including runoff problems).

- Saltwater intrusion resulting from reduction of freshwater flow (e.g., reduced flow caused by upstream modifications).

- Changes in water movement, flow or circulation caused by dams, levees, channels, causeways, or diversion facilities. (Sec. $304(\mathrm{e})(2))$.

f. Using this and other information provided by EPA, planning agencies are to develop a plan which describes

o What treatment works will be needed over a 20-year period.

- How the planning agency will deal with nonpoint sources of pollution including urban stormwater runoff, agricultural sources, mine-related sources and construction-related sources.

o How it will deal with saltwater intrusion into rivers, lakes, and estuaries resulting from reduction of fresh water flows.

- How it will control disposition of residual wastes.

$$
\mathrm{B}-6
$$




\section{Enforcement}

Basically, enforcement is by way of policing discharge limitations and water quality standards. EPA (or the state) may issue compliance orders, initiate civil actions in Federal district courts, or bring criminal actions punishable by fines (up to $\$ 25,000$ per day) or imprisonment. Citizens suits are also authorized.

\section{Other Affected Authority (Sec. 511)}

1. The authority of the Secretary of the Army is not affected except that dredge/fill permits as reviewed by EPA are conclusive as to the dredge/fill operation's effect on water quality. $1 /$

2. Discharges under the Rivers and Harbors Act of 1910, and the Supervisory Harbors Act of 1888, are to be regulated pursuant to this act except as to effect on navigation and anchorage. 1/

3. Except for waste treatment plant construction, and the issuance of discharge permits, EPA actions under the act are not "major Federal action" for NEPA purposes (i.e., no environmental impact statement is required).

\section{Definitions}

o "Pollution" means the man-made or man-induced alteration of the chemica1, physical, biological and radiological integrity of water. (Sec. $502(19))$.

o "Pollutant" means dredged spoil, solid waste, incinerator residue, sewage, garbage, sewage sludge, munitions, chemical wastes, biological materials, radioactive materials, heat, wrecked or discarded equipment, rock, sand, cellar dirt and industrial, municipal, and agricultural waste discharged into water. (Sec. $502(6))$.

o "Toxic pollutant" means those pollutants, or combinations of pollutants, including disease-causing agents, which after discharge and upon exposure, ingestion, inhalation or assimilation into any organism, either directly from the environment or indirectly by ingestion through food chains, will, on the basis of information available to the Administrator, cause death, disease, behavioral abnormalities, cancer, genetic mutations, physiological malfunctions (including malfunctions in reproduction) or physical deformations, in such organisms or their offspring. (Sec. 502(13)).

1/ See discussion of Army Corps of Engineers' responsibilities under the Federal Water Pollution Act, the Rivers and Harbors Act, and the Marine Protection, Research, and Sanctuaries Act infra. 
"Point source" means discrete conveyance, including but not limited to any pipe, ditch, channel, tunnel, conduit, well, discrete fissure, container, rolling stock, concentrated animal feeding operation, or vessel or other floating craft, from which pollutants are or may be discharged. By regulation, EPA had at one time limited the definition of this term to exclude certain hard-to-manage pollution sources such as storm sewers, small feedlots, and irrigation return flows. The district court in NRDC v. Train 396 F. Supp. 1393 (D. DC, 1975) held that this definition was too restrictive and contrary to the intent of Congress, thus requiring EPA to issue guidelines for these sources.

- "Navigable waters" means the waters of the United States, including the territorial seas. This has been interpreted to mean all waters of the United States which affect interstate commerce without regard to their navigability. $\underline{1}$

\section{Reports}

EPA is required to submit an annual report to Congress which gives an overview of the progress toward implementation of the act, problems associated with implementation, status of state programs, enforcement actions pending or completed, and the costs of carrying out the provisions of the act.

Each state must submit an annual report which includes a description of the water quality, the extent to which the waters provide for the protection and propagation of a balanced population of shellfish, etc., analysis of the impact of the effluent limitations on meeting the goals of the act, estimate of social and economic costs necessary to achieve the goals, and a description of the nature and extent of nonpoint sources of pollutants and recommendations for programs to control them.

If U.S. v. Holland, 373 F. Supp. 665 (M.D. Fla., 1974). (E1sewhere in this Appendix appears a discussion of "navigable waters" under the 1899 Rivers and Harbors Act. It is pointed out there that "navigability" is a meaningful point of reference relevant to the Corps of Engineers'responsibility to keep waters free of impediments to navigation. In U.S. V. Holland, the court found that the Congress in passing FWPCA, had defined away the navigability restriction such that "...the sole limitation on the reach of Federal power (is) the commerce clause." 373 F. Supp. 665, 671. The court went on to say that "... water pollution has a serious effect on interstate commerce and... Congress has the power to regulate activities which cause such pollution." 373 F. Supp. 665, 673)). 
A report of the National Study Commission on Water Quality established by the act was to be submitted three years after passage of the legislation. $1 /$

FWPCA, prior to 1972, contained provisions calling for a report to Congress (developed by the Secretary (later Administrator of EPA), Secretaries of the Army, Agriculture, and the Water Resources Council)) which was to include: $\underline{2}$

- An analysis of the importance of estuaries to the economic and social well-being of the people of the United States and of the effects of pollution upon the use and enjoyment of such estuaries.

o A discussion of the major economic, social, and ecological trends occurring in the estuarine zones of the Nation;

o Recommendations for a comprehensive national program for the preservation, study, use, and development of estuaries of the Nation, and the respective responsibilities which should be assumed by Federal, state, and local governments and by public and private interests.

Proposed Amendments

Amendments have been proposed that would

- Grant EPA authority to extend the July 1, 1966 requirement for the achievement of "best practicable control technology" by industrial discharges and "secondary treatment" by municipal dischargers.

o Replace the 1985 "no discharge" goal with a less stringent goal.

o Postpone "best available technology" 1983 requirement.

- Allow for consideration of receiving water's capability to absorb a given discharge.

- Grant EPA flexibility to selectively waive or modify the 1977 best practicable control technology requirement on a case-bycase basis.

- Relate toxic pollutant discharge permit requirements to background pollution levels (i.e., using receiving water standards).

1/ "Report to Congress," National Commission on Water Quality, March 18, 1976.

2/ "The National Estuarine Pollution Study," U.S. Department of the Interior, March 25, 1970. 
- Establish pretreatment requirements as only general requirements and give municipalities the sole authority to establish specific treatment requirements.

- Restrict wetlands jurisdiction of the act such that the Corps of Engineers' authority would be limited to traditional definition of "navigable waters"--i.e., below the tide line.

These proposed amendments and their effect on water quality and on shellfish habitat are discussed in the body of the report.

\section{Comment}

(May be found within body of report in Section VI.)

2. Section 404, Federal Water Pollution Control Act Amendments of 1972, P.L. 92-500, Sec. 2, 86 Stat. 884, U.S.C. 1344 (1974)

\section{History}

Dredge-and-fill operations, particularly in estuarine areas, have a well-recognized negative impact on shellfish production. Since the 1899 Rivers and Harbors Act, Congress has placed primary authority to regulate such activity with the Army Corps of Engineers but only for the purpose of maintaining navigation. The Congress has experimented with several statutory schemes that would have the Corps consider fish and wildlife protection as well as navigability in its dredge-and-fill permit programs. The problems of coordination and resolution of conflicts between the navigation interests of the Corps and the water quality interests of the newly formed Environmental Protection Agency arose in a number of court cases after 1970. There was initial confusion about overlapping jurisdiction. Congress finally attempted to settle the issues by incorporating Section 404 into the 1972 Federal Water Pollution Control Act Amendments. (See comment following discussion of Marine Protection, Research and Sanctuaries Act.)

\section{Purpose}

The purpose of this act is to coordinate (1) the authority of the Army Corps of Engineers to permit the discharge of dredge-and-fill material into navigable waters with (2) the expertise of the Environmental Protection Agency in evaluating the negative impact of such discharges on water quality and local ecosystems. 


\section{Implementation}

The Administrator of the Environmental Protection Agency in conjunction with the Corps promulgates guidelines (40 C.F.R. 230) for determining degradation of navigable waters using as a minimum the criteria listed in Section 403 of the act (33 U.S.C. 1343). (These criteria are set out in the summary of the Federal Water Pollution Control Act, supra, under "Implementation," Sec. 2(e).)

The Corps is then responsible for applying the Environmental Protection Agency guidelines to each dredge-and-fill permit application. If the guidelines would prohibit the specification of a discharge site, the Corps may proceed to evaluate the economic impact of the proposed activity and to balance the economic impact against the water quality impact to determine whether the permit might still be in the public interest.

The Administrator retains authority to deny or restrict the uses of any specific disposal site whenever he determines, after public notice and opportunity for comment, that the discharge of materials will have an "unacceptably adverse effect" on water supplies, shellfish beds and fishery areas, wildlife, or recreational areas. He must consult with the Secretary of the Army before exercising this veto of the Corps permit, although the act leaves the Administrator with the ultimate veto authority.

The act still left two issues unresolved. First, to what extent does the act change the definition of "navigable waters"? In 1975, a U.S. District Court ordered the Corps to promulgate guidelines for permits to discharge dredge-and-fill materials into all of the waters of the United States, specifically including wetlands, a major shellfish area. 1 l

Second, which agency has the primary duty to enforce Section 404? FWPCA is silent as to 404 enforcement. As a result, negotiations were undertaken toward an interagency agreement that appears to place this responsibility in the hands of the Corps, with independent EPA action to be taken in appropriate cases such as emergencies.

1/ NRDC V. Ca1laway, 392 F. Supp. 685 (1975). 
Section 516 of FWPCA as amended, requires EPA to submit a comprehensive report within 90 days after each session of Congress is convened. $1 /$

\section{$\underline{\text { Comment }}$}

(Comment section is integrated with discussion of Corps of Engineers' responsibilities, which follows the Marine Protection, Research, and Sanctuaries Act of 1972, infra.)

3. Rivers and Harbors Act of 1899, 30 Stat. 1151-1154, 33 U.S.C. 401 et seq. (1974): Act of March 3, 1905, 33 Stat. 1147, 33 U.S.C. 419 (1974); and Other Miscellaneous Provisions of U.S. code, Title 33

\section{History}

The 1899 legislation was seminal in its delegation to the Army of the explicit Congressional power to regulate navigable waterways. It came at the threshold of the 20th century, when the United States had secured internal peace and developed economic strength through its industrial revolution. The Nation viewed its future in terms of its impressive economic potential and its growing power in foreign trade markets. Just as an ambitious program of railroad construction had fostered domestic growth, so the development of harbors and waterways would prove valuable in maintaining an international position of economic and strategic strength. Moreover, the military possessed the engineering expertise of the day. Those dual themes--economic development coupled with military experience and strength--help to explain why the Nation's first comprehensive statutory water use regulations came to be implemented by the Army's Corps of Engineers. Environmental protection was not a part of this original scheme.

\section{$\underline{\text { Purpose }}$}

The purpose of this act is to promote the Army's control and improvement of harbors and waterways by dredging, filling, diverting, and impounding waters, and to prevent the obstruction and degradation of navigable waterways by other users and by adjacent (riparian) landowners. The act modifies the common law "reasonable use doctrine" governing water rights by expressly forbidding watercourse obstructions except under permits issued by the Secretary of the Army.

1/ The Environmental Protection Agency has in fact issued reports on its enforcement activities for the years 1970-72, 1972-74 and 1975, respectively. These reports describe section 404 enforcement activity. 


\section{Definitions}

The term "navigable waters" has been defined more and more broadly over the years by the courts. The original judicial definitions included rivers, streams, and lakes capable of supporting waterborne commerce, and coastal waters from the mean high tide mark seaward. (The Daniel Ball, 10 Wall. 557, 77 U.S. 557 (1870).) This was expanded to include watercourses whose past history of commercial use made them navigable despite subsequent physical or economic change. (Economy Light and Power Co. v. United States, 256 U.S. 113 (1921).) The term was further expanded to include watercourses that could be made navigable if modified by "reasonable improvement." (United States v. Appalachian Electric Power Co., 311 U.S. 377 (1940).) Because the Rivers and Harbors Act was designed to keep the navigable waters of the United States free of impediments to navigation, these "reaches" of the definition proved satisfactory. Recent developments in the definition of "navigable waters" as used in the Federal Water Pollution Control Act encompass bays, estuaries, and marshlands with definable ecological or economic links to be more traditional "navigable" bodies of water. See 33 C.F.R. 209.260.) (See further discussion of the term "navigable waters" under the accompanying FWPCA material.)

\section{Implementation}

The construction of dams and dikes $\frac{1 /}{5}$ and the dumping of refuse materials, $2 /$ or "any obstruction or alteration" $3 /$ in navigable waters or their tributaries not affirmatively authorized by Congress are expressly prohibited unless an authorized official of the Army Corps of Engineers has issued a permit for such activity.

The act gives the Army unfettered discretion to deny a permit for the above activities in the interests of navigability or anchorage. The Corps has promulgated regulations from time to time to reflect its evolving policies regarding these interests. (33 C.F.R. 209.120.) However, in recent years, Congress has enacted legislation dealing with water-related interests other than navigation, and has required the Corps to coordinate with or defer to the judgment of other state and Federal agencies vis-a-vis the issuance of permits. These statutes include the Fish and Wildife Coordination Act, the Federal Water Pollution Control Act, and the Marine Protection, Research, and Sanctuaries Act, all discussed herein. The Environmental Protection Agency, the Fish and Wildlife Service, and the National Marine Fisheries Service are the agencies most frequently involved in the coordinating effort.

\begin{tabular}{ll}
\hline $1 /$ & Rivers and Harbors Act, Sec. 9 (33 U.S.C. 401) \\
$\underline{2} /$ Id., Sec. 13 (33 U.S.C. 407) \\
$\underline{3}$ Id., Sec. 10 (33 U.S.C. 403)
\end{tabular}


Surveillance and other enforcement activities are conducted by the Corps through its own staff, its harbor supervisors and their patrol boats, the Coast Guard, and with other Federal agencies' resources made available to the Corps by interagency agreement.

Two sections of Title 33 U.S.C. giving the Corps various authorities relate explicitly to shellfish. 33 U.S.C. 419 (33 Stat. 1147) authorizes the Army to regulate the dumping of dredging and refuse except in waters within state boundaries that are used for lawful oyster cultivation. However, if such waters are a "navigable channel of interest to the United States" the exception does not apply, and the Army maintains its authority to regulate.

33 U.S.C. 452 (28 Stat. 360, Act of August 18, 1884) makes it unlawful "to engage in fishing or dredging for shellfish" in any channels leading to New York Harbor. The statute simply seeks safe navigation in this particularly busy harbor area.

\section{Oversight}

The 1889 Act provides no oversight other than that of the Secretary of the Army over the Chief of Engineers. It also clearly reserves to the Congress the power to authorize and approve projects in navigable waters. Any review of Army activities carried out pursuant to the 1899 Act must come under the provisions of other, more recent legislation. (See the accompanying discussions of the Fish and Wildlife Coordination Act, the Federal Water Pollution Control Act, and the Marine Protection, Research, and Sanctuaries Act.)

\section{Reports}

The Rivers and Harbors Act of 1899 does not require reports by the Secretary of the Army or by the Corps of Engineers to any other agency or to Congress. It does imply internal reporting in that the secretary of the Army may grant permits upon the recommendation of the Chief of Engineers.

\section{Comment}

(Comment section is integrated with discussion of Corps of Engineers' responsibilities which follows the Marine Protection, Research and Sanctuaries Act of 1972, infra.). 
4. Marine Protection, Research, and Sanctuaries Act of 1972, P.L. 92-532, 86 Stat. 1052, as amended by the Act of March 22, 1974, P.L. 93-254, 88 Stat. 50, 33 U.S.C.A., 1401 et seq. (1976 Supp.) 33 C.F.R. 209.120

\section{History}

National and international publicity has decried the increasing volume and toxicity of materials being dumped into the oceans. Part of the concern is the economic and health consequences to nations that rely on the oceans' fish resources. Concerned that stringent controls on domestic dumping under the Federal Water Pollution Control Act Amendments of 1972 would encourage the dumping of materials outside the three-mile limit, Congress enacted the Marine Protection, Research and Sanctuaries Act of 1972.

\section{Purpose}

The purpose of this act is to regulate the dumping of all materials into ocean waters, and to prevent or strictly limit the dumping of those materials that would adversely affect:

o Human health, welfare, or amenities

o The marine environment

- Ecological systems

- Economic potentialities

The act also encourages research into ocean pollution and its effects on the interests listed above, and authorizes the establishment of marine sanctuaries that would preserve pristine conditions and provide baseline information for the purposes of marine research.

\section{Implementation}

The act is organized into three parts (titles): ocean dumping, research, and marine sanctuaries.

\section{Ocean Dumping}

The act seeks to control dumping by regulating the transport of any material out of the United States for dumping into ocean waters, and the dumping of material transported from outside the United States, if the dumping occurs in waters over which the United States may exercise jurisdiction and control under international law. Transport in either case is prohibited unless authorized by a permit issued by the Environmental Protection Agency or by the Army Corps of Engineers. 
The Corps' permit jurisdiction for the purposes of this act relates solely to the transportation and dumping of material dredged or excavated from the navigable waters of the United States, and is subject to the veto of the Administrator of the Environmental Protection Agency.

The Corps may issue its own permit after public notice and opportunity for hearing if it finds no "unreasonable degradation or danger" to the four interests listed above (33 U.S.C. Sec. 1413(a)). In addition, the Secretary of the Army may make an independent analysis of the effect of a denia1 on

- Navigability

- Economic and industrial development

- Foreign or domestic commerce

in order to weigh the need for the dumping (Sec. 1413(b)). Alternative sites must be considered (Sec. 1413(b)). If there is no economically feasible alternative to dumping, the Secretary must certify that finding; the Enviromental Protection Agency then has 30 days in which to exercise a veto of the permit (Sec. 1413(c) and (d)). The sole ground on which the veto may be exercised is that the material will result in "unacceptably adverse" impacts on (e.g.) shellfish beds, spawning and breeding areas, or other parts of the marine environment (Sec. 1413(d)).

The Environmental Protection Agency's permit jurisdiction is much broader than that of the Corps, covering virtually all materials other than dredged materials (Sec. 1412(a)). The Administrator must use at least the following criteria in evaluating a given permit application, after giving public notice and opportunity for comment (Sec. 1412(a)):

o The need for the dumping.

o The effect on health, welfare, economics, aesthetics, and recreation.

o The effect on fisheries resources, plankton, fish, shellfish, wildlife, shorelines, and beaches.

- The effect on marine ecosystems, particularly the concentration and dispersion of the dumped materials and the potential changes in marine diversity, productivity, and stability.

- Such other criteria as may be suggested by the Fish and Wildlife Service, and other Federal, state, and local agencies, and by the general public as may appear appropriate. 
The Environmental Protection Agency and the Corps of Engineers are authorized to use the skills and resources of the U.S. Coast Guard to perform surveillance, compliance monitoring, arrest, search, and seizure for the purposes of enforcing the act (Sec. 1417).

The act provides for both civil and criminal penalties (Sec. 1415). A particularly critical provision of the act gives any person standing to sue in Federal court tó enjoin any alleged violations either by private party or by a Federal, state, or local agency (Sec. 1415(g)(1)). Tempering the incentive for frivolous citizen suits is a provision empowering the court to award attorneys' fees and costs as appropriate (Sec. 1415(g)(4)) .

\section{$\underline{\text { Research }}$}

The second major part of the act mandates a comprehensive program of monitoring and research by the Department of Commerce on the effects of dumping in the ocean, in other tidal waters, in the Great Lakes, and in connecting waters. It further directs the Department of Commerce to study long-range effects of pollution, overfishing, and other man-induced changes in ocean ecosystems. Substantial appropriations are authorized for these research goals.

\section{Marine Sanctuaries}

The Secretary of Commerce is further directed to designate marine sanctuaries in ocean waters along the continental shelf and to regulate activities in these sanctuaries so as to preserve and restore them for conservation, recreation, aesthetic, and ecological purposes. Only after consulting with local states affected and with Secretaries of State, Defense, Interior, Transportation, and with the Administrator of the Environmental Protection Agency, and after approval by the President, may the Secretary of Commerce so designate these areas.

Civil penalties alone are established for violation of any forthcoming regulations. The act carefully limits its reach to only those persons otherwise subject to United States jurisdiction consistent with principles of international law. This section of the act is apparently an advance framework for implementing future treaties and international conventions on the law of the sea.

\section{$\underline{\text { Reports }}$}

The Environmental Protection Agency must submit an annual report to Congress on its administration of the act. The Secretary of Commerce must submit to Congress a report on its ocean dumping research program at least annually. 
(Note: the following comment integrates discussion of Corps responsibility under FWPCA and the Rivers and Harbors Act (dredge-and-fill permitting) and the Marine Protection, Research, and Sanctuaries Act (ocean dumping)).

Bays, estuaries, and marshlands are highly important as spawning and nursery ground for many commercial species of shellfish. Dams, dikes, and dredge-and-fill operations in those areas by private and public agencies to aid navigation and to provide new land for development have increased tremendously. Many bayfill projects have transformed once fertile shoreline into biological deserts. Similarly, as domestic water quality controls have tightened, dredged materials have been more frequently dumped in ocean waters outside the three-mile limit, adversely affecting the quality and yield of shellfish collected at sea. Not only does dredging and filling change the physical shape and biological structure of shellfish beds, but such activity often unearths or introduces pollutants into the shellfish ecosystem. Some pollutants simply kill fish, while others are ingested by and become concentrated in the fish, creating a public health hazard for humans who eat shellfish.

The shellfish industry has clearly had a powerful incentive to seek strong regulation of dredge-and-fill and other watercourse modification projects by public and private agencies. Such regulation has traditionally been performed by the Army Corps of Engineers, whose original functions were simply to improve navigability for economic and strategic strength, not to protect the environment or the shellfish industry. Modern-day Corps regulation, however, is more inclusive of an obligation to protect the shellfish habitat. This broadening of focus by the Corps has had a stepby-step development, as will be discussed:

Since at least 1899, when Congress passed the Rivers and Harbors Act, the Corps has had authority for an extensive permit program regulating dumping and alterations to navigable waters. With the Fish and Wildlife Coordination Act some 50 years later, Congress directed the Corps to consider fish and wildlife protection and enhancement in its project plans and permit deliberations. In a 1967 Memorandum of Understanding, the Corps and the Fish and Wildlife Service established a coordination procedure. 1/

In the previously described case of Zabel v. Tabb, the Corps exercised its environmental responsibility in denying a dredge-and-fill permit to a developer. The appellate court upheld the Corps' action citing the 1958 Fish and Wildlife Coordination Act (16 U.S.C. 661 et seq.), the environmentally-based objections of the Fish and Wildlife Service, and the 1967 Memorandum of Understanding between the Secretary of the Interior and the Secretary of the Army mentioned above.1/

1/ $430 \mathrm{~F} \cdot 2 \mathrm{~d} 199(1970)$. 
In 1970, the President issued Executive Order No. 11547 in an effort to implement a national industrial pollution discharge control program using the Corps' permit authority under the 1899 Rivers and Harbors Act.

The passage of the National Environmental Policy Act of 1969 (NEPA) and the formation of a central, technically qualified Environmental Protection Agency placed another duty on the Corps (and all Federal agencies) to effectuate government environmental policies (42 U.S.C. 4321-4347). Relevant to the issues at hand, NEPA raised the issue of coordinating and resolving conflicts between the navigation and anchorage responsibilities of the Corps and the water quality interests of the Environmental

Protection Agency, while requiring a look at such other considerations as the shellfish responsibilities of the Fish and Wildlife Service (see accompanying discussion of NEPA). Congress incorporated Section 404 of the 1972 Water Act Amendment to define the mutual responsibilties of the Corps and EPA. Almost simultaneously, Congress enacted the Marine Protection, Research, and Sanctuaries Act of 1972 to establish a parallel statutory scheme for EPA and the Corps to coordinate in an ocean dumping permit program.

Following the 1972 acts, the Corps promulgated regulations incorporating environmental considerations into the permit evaluation process. However, it took a restrictive view of the "navigable waters" under its jurisdiction, and did not involve itself with requiring permits for wetlands dredge-andfill activity. The Corps had traditionally concerned itself with private operations anywhere seaward of either harbor lines or mean high tide marks. Wetlands, of course, usually included the estuaries and marshes landward of (and therefore outside) these jurisdictional lines. In 1975, a Federal court ordered the Secretary of the Army to adopt new permit.regulations offering protection to environmental and shellfish interests in all of the waters of the United States under its authority found in Section 404 of the 1972 Water Act. If The new regulations are being phased in over a threeyear period beginning in July 1976 to cover wetlands permits (33 C.F.R. $209.120(\mathrm{~g})(3))$.

1/ 1976 saw legislation introduced in the Congress related to this court decision. The proposed legislation would delimit the Corps of Engineers Section 404 permit authority to the traditional navigable waters definition. This would leave unregulated dredge-and-fill activities in wetlands areas above the mean high tide mark. Conceivably, these wetlands could then become a free-fill zone subject only to local control. (See H.R. 9560 and S.2710, 94 th Congress, 2nd. Session, 1976). 
The laws affecting the Corps' authority to regulate water projects have potential for beneficial impact insofar as they (1) provide the Corps with expert consultation on shellfish problems, and (2) give the Corps a duty to weigh shellfish interests with other interests such as navigation in evaluating a project permit. The Corps must apply the expertise of the Fish and Wildlife Service, the Environmental Protection Agency, the National Marine Fisheries Service, and state agencies (such as fish and game agencies) in reaching each permit decision. (See 16 U.S.C. 662(a) and 33 C.F.R. 209.120(d).) 1 Moreover, there is an opportunity for public comment (and public hearings, where appropriate) after each permit application is filed.

There is recourse to the Federal courts for judicial review of the Corps' administrative action in granting a permit, or for the Environmental Protection Agency's failure to veto a permit, when it is felt that the action significantly lowers water quality and results in negative impacts on the shellfish industry at a given locale. But the courts will not act unless petitioned. In this regard, environmental groups, Federal and state fisheries agencies, and the shellfish industry itself are all in a position to monitor permit applications that could have serious impact on fishery habitats.

A final point deserves comment: To be effective, the permit system must be enforced. In the 1971 Puget Sound hearings, Congress learned that an estimated 80 percent of the structures in place were there without a permit--some 50,000 illegal structures in the Sound. The Corps seldom refers criminal cases to the U.S. Attorney unless there has clearly been a willful violation. ${ }^{\prime}$ It must rely on other agencies such as the National Marine Fisheries Service, the Fish and Wildlife Service, and state fishery agencies for leads, and it must rely on the Coast Guard for surveillance and arrest.

The Environmental Protection Agency has elected to leave dredge-andfill enforcement to the Corps, though the EPA does have general water quality enforcement powers of its own. Fortunately, with the new civil penalty provisions in the 1972 acts, the stiff "reasonable doubt" burden of proof is relaxed. Thus, enforcers may be more willing to prosecute: the easier the burden of proof, the greater the likelihood of a successful prosecution, and the greater the incentive for strict enforcement.

Perhaps even more important to the enforcement issue are the citizen suit provisions of the 1899 and 1972 acts. The mechanism is there for the public, Federal, and state agencies, and for the shellfish industry to protect the shellfish habitat by carefully monitoring dumpers and dredging operations and their effect on water quality.

I/ But see discussion accompanying Fish and Wildlife Coordination Act (16 U.S.C. 661-664), which details problems with the provision of such input.

2/ An enforcement action taken in the State of Washington in July of 1976 led to a Federal court finding that the shellfishermen engaged in hydraulic clam harvesting in privately leased tidelands of Puget Sound were required to obtain a permit from the Corps of Engineers for their dredging operation. 
5. Fish and Wildlife Coordination Act of 1958, P.L. 85-624, 72 Stat. 563, 16 U.S.C. 661-664 (Amending the Original Act of 1934 (48 Stat. 401) and the Coordination Act of 1946 (60 Stat. 1080))

\section{History}

The Coordination Act of 1946 (60 Stat. 1080) authorized the Fish and Wildlife Service to consult with any public agency or private Federal licensee or permittee planning to alter any stream or body of water, with a view to minimizing the decline of wildlife resources. However, after 12 years of experience with the 1946 act, the Congress noted the following deficiencies (Senate Report No. 1981, July 28, 1958):

- No clear authority for the Fish and Wildlife Service to enhance or improve fish resources by suggesting changes in another agency's water projects.

- No clear application to dredging of (or other impacts on) bays and estuaries--i.e., on major shellfish spawning and nursery grounds--either by the Government or by private interests.

o No clear application to the backlog of hundreds of Army Corps of Engineers' projects already authorized but not yet underway.

o No clear relative weights assigned to fish and wildlife interests.

The Senate Report accompanying the 1958 act also makes it clear that shellfish may be affected by dam construction upstream. This interference with the flow of fresh water to the sea allows salt water incursion to take place at the river mouth, altering the salinity of the water in the estuary. The Report notes too that dredging, filling, and diking operations, carried out to improve navigation and to provide new industrial or residential land, can disturb nursery and feeding grounds.

Considering these facts, and in contemplation of an expected exponential growth in water projects, Congress passed the 1958 Coordination Act.

\section{$\underline{\text { Purpose }}$}

The purpose of this act is to ensure that commercial and sporting fish and wildlife concerns are considered equally with navigation, landfill, hydroelectric power generation, flood control, and other water resource interests whenever a Federal agency plans, licenses, or permits a watercourse modification for any purpose whatever.

\section{Definitions}

"Wildlife" means birds, fishes, mammals, and all other classes of wild animals, as well as aquatic and land vegetation on which wildlife depends. 


\section{Implementation}

The act mandates that the public agency performing or permitting any water diversion, impoundment, dredging, filling, or other watercourse alteration shall consult with the Fish and Wildlife Service and the appropriate state wildlife agency to determine the impacts of the project on fish and wildlife. That agency may incorporate suggestions for protecting, conserving, and enhancing wildlife resources into the project plan, but it is not mandatory.

The act authorizes the transfer of monies from the Federa1 agency proposing construction of a watercourse modification to the Fish and Wildlife Service for the Service to carry out its wildlife impact investigations and coordinated planning. Said monies are to come out of the project's appropriations or other funds designated for investigations, engineering, or construction. This authority to transfer, however, is discretionary and refers only to the Fish and Wildlife Service as the potential recipient of funding.1/

The water project itself and any areas of land or water acquired in connection with the project shall have provision made for the conservation, maintenance, and management of wildlife resources and their habitat. The use of these waters and lands shall be in accordance with plans approved by the particular agency head, the Secretary of the Interior, and the appropriate state wildlife agency representative.

In addition, lands and waters may be acquired by Federal construction agencies for the very purpose of preserving the wildlife potential of the particular project area.

The Secretary of the Interior, through the Fish and Wildiife Service and the Bureau of Mines, is authorized to investigate the effects of domestic sewage, mine, petroleum, and industrial waste, erosion silt, and other polluting substances on wildlife, and the secretary is authorized to make reports to Congress along with recommendations for alleviating the effects of pollution. These investigations shall include:

o Determination of standards of water quality for the maintenance of wildlife.

o The study of methods of abating and preventing pollution (including recycling of wastes).

o The gathering of data and the distribution of study results to Federal, state and local governments or to private organizations.

1/ Under Reorganization Plan No. 4 of 1970, functions carried out by the Secretary of the Interior (Bureau of Commercial Fisheries) were vested in the Secretary of Commerce (National Oceanic and Atmospheric Administration--National Marine Fisheries Service). 
One Federal agency with extensive authority over water resources projects is the Corps of Engineers. (See accompanying discussion under Rivers and Harbors Act, FWPCA, Section 404, and Marine Protection, Research, and Sanctuaries Act.) In 1967, the Secretary of the Interior and the Secretary of the Army issued a Memorandum of Understanding that outlines in detail the administrative procedures by which the Corps of Engineers is to accommodate the findings and opinions of the Fish and Wildlife Service for Corps projects, including its permitting activities. However, as is the case with all Federal licensing or permitting agencies, the Corps retains final permit authority.

Regulations voluntarily promulgated by the Corps in 1968 led to a broadening of jurisdiction relating to the consideration of environmental impacts of its programs, specifically, to water quality and wildlife values consistent with the 1958 Coordination Act. A number of court decisions beginning with Zabel $\mathrm{v}$. Tabb1 have resulted in a framework within which the Corps is to take an affirmative stance with respect to protection of wildlife, and with respect to other environmental concerns spelled out in related legislation since 1970. The Zabel case confirmed the Corps' authority to rely on the 1958 Coordination Act in making a permit decision. In a 1974 case, the issue arose as to whether Corps jurisdiction for dredgeand-fill activity under FWPCA, Section 404 extended to wetlands above the high tide line. The court said it did.2/ Following a 1975 court order, the Corps adopted comprehensive regulations governing the administration of their permit programs for navigable waters.1/ These regulations explicitly direct District Engineers to consider effects of project activities on shellfish (among other interests) and to deny (or place conditions on) a permit where the net public benefit is negative or uncertain. 2 /

(33 C.F.R. 209.120(f)).

1/ 403 F.2d 199 (1970) Mssrs. Zabel and Russe11 owned land on Boca Ciega Bay near St. Petersburg, Florida. They wished to dredge and fill on their property to build a trailer park. The Corps of Engineers denied their request for a permit even though there would be no effect on navigation. The Corps based its denial on environmentally based opposition by the U.S. Fish and Wildlife Service, stating that because of this opposition, approval would be inconsistent with the intent of Congress as expressed in the Fish and Wildlife Coordination Act. The land-owners filed suit and prevailed at the District Court level (296 F. Supp. 764). However, the Court of Appeals reversed, holding that, indeed, the Corps could refuse to issue a permit for substantial ecological reasons even though the project would not interfere with navigation, flood control, or the production of power.

2/ U.S. v. Holland, 373 F. Supp. 665 (M.D. F1a. 1974). 
The 1958 Coordination Act improved Congress' ability to evaluate the performance of such water project agencies as the Corps of Engineers and the Bureau of Reclamation by mandating that both the Fish and Wildife Service report and the terms of the final project permit be incorporated into the Agency's annual report to Congress. Also, judicial review of agency action is available under Section 702 of the Administrative Procedures Act. $\underline{3}$ /

\section{$\underline{\text { Reports }}$}

The Act clearly requires the inclusion of findings and opinions of the Fish and Wildlife Service in annual reports by the Corps to Congress, as well as in the reports to the Congress originating with any other water project agency. Individual watercourse project recommendations to Congress by an agency shall include an estimate of the wildlife benefits or losses associated with the project. Congress could then incorporate conservation measures into its approval and funding of the project.

\section{Comment}

The Fish and Wildlife Coordination Act of 1958 is an important environmental law. It preceded the National Environmental Policy Act (NEPA) by 12 years in its call for the incorporation of wildlife interests in water resource activities. The original act of 1934 recognized the need for research into the effects of water pollution on wildlife and for study of methods of preventing and abating pollution.

Although not foreseen at the time, the act has become an integral part of the implementation of water quality permit programs under the Federal Water Pollution Control Act and the Marine Protection, Research, and Sanctuaries Act. Permitting activities of EPA and the Corps of Engineers are reviewed under the provisions of this act. The act currently provides the primary mechanism for consideration of fish and wildlife resources in Federal programs involving the planning, construction, and regulation of activities which have an impact on the resource habitat. Thus, the Fish and Wildlife Service and the National Marine Fisheries Service have the opportunity to comment on the activities contemplated within a given permit request as to the effects of that activity on fish and wildlife. This is similar to the opportunity afforded these agencies to provide analyses for and a review of environmental impact statements (EISs) on major Federal actions pursuant to NEPA. However, the opportunity for input to the

I/ N.R.D.C. V. Callaway, 392 F. Supp. 685 (1975). See 33 C.F.R. 209.120.

2/ Under Reorganization Plan No. 4 of 1970 , functions carried out by the Secretary of the Interior (Bureau of Commercial Fisheries) were vested in the Secretary of Commerce (National Oceanic and Atmospheric Administration--National Marine Fisheries Service). The NMFS was afforded the opportunity to comment on activities which affect fishery resources.

3/ 5 U.S.C. 551 et seq. 
permitting and planning process is superior to that of EIS review and comments. This is because the FWCA provides opportunity to advise the construction or permitting agency of the resource involvement, potential impacts and potential means to prevent damage to resources during the earliest phases of a project or permit planning and not after the plan has been completed and approaches the final decision stage as occurs with an EIS.

It should be noted that, as is the case with EIS's this opportunity to comment does not include the power to halt a given activity. Quoting from the legislative history:

"The legislation would be a permissive law so far as it concerns relationship between project construction agencies and fish and wildlife conservation agencies. The latter would not be given any veto power over any part of the water resource development program." (Senate Report No. 1981, July 28, 1958).

Nevertheless, it is important that the opportunity for comment by fish and wildlife agencies is provided. Their identification of a threat to fish and wildlife might result in a veto by the permitting agency (EPA or Corps) that does have the power to say no to a given permit request.

The effectiveness of this law will be greatly influenced by the degree to which fish and wildlife agencies are staffed and funded to provide the analyses necessary for critical comment on proposed construction projects and on the permits (and EISs) referred to them by the Federal permitting and licensing agencies, in particular, EPA and the Corps of Engineers.

In addition, extensive experience with the act has revealed a need for amendment and strengthening of the act. "A Marine Fisheries Program for the Nation"I/ recommends amendment of the act. It recognizes that such amendments might include:

(1) Expanding coverage to projects and developments of all Federal and development agencies, including outer continental shelf development.

(2) Including NOAA (National Marine Fisheries Service) specifically among agencies which are to be consulted on fisheries impacts.

(3) Strengthening mechanisms for effective consideration of fisheries habitat.

(4) Provide for mandatory transfer of funds from Federal construction and licensing agencies to fish and wildlife agencies for conducting studies and investigations required by the act.

If U.S. DOC., NOAA, NMFS, July 1976 (p. 39). 
6. Estuarine Areas Act, P.L. 90-454, 16 U.S.C. 1221-1226

\section{History}

Senate Report No. 1419 (July 17, 1968) declared that many estuarine ecosystems are being altered to the detriment of desirable organisms by pollution, poor water flow control, and by development resulting from population pressures for housing, industrial development, and other man-made structures such as hurricane protection breakwaters.

\section{Purpose}

The purpose of this act is to protect, conserve, and restore these estuaries in a manner that provides an appropriate balance with the national need for developing them. A further purpose is to recognize and to maintain state responsibility in this regard.

\section{Implementation}

The Secretary of the Interior was directed to conduct an inventory of the nation's estuaries and to adjudge them as to the following factors:

- Wildife and recreational potential

- Ecology

o Value to marine, anadromous, and shellfisheries

o Aesthetic value

- Importance to navigation

o Value for flood, hurricane, and erosion control

o Mineral value

o Value of their submerged lands

o Value for more intensive development for economic use (urban/commercial/industrial development) 
The study $1 /$ was to be conducted in conjunction with an estuarine pollution study, authorized under the Federal Water Pollution Control Act.2

The Secretary was also to consider whether any estuarine area should be acquired or administered by the Secretary or by a state or local subdivision, or whether such area could be adequately protected through existing law.

Section 1224 requires that where a Federal agency's activities will affect an estuarine area, the agency shall give consideration to the effects of those activities on the estuary, and where plans affecting an estuarine area are to be submitted to the Congress for approval, the Secretary of the Interior shall be afforded an opportunity to comment on those effects.

\section{$\underline{\text { Reports }}$}

The Secretary of the Interior was directed to submit the National Estuary Study and Inventory to the Congress via the President not later than January 30, 1970.ㄱ/

\section{Comment}

This legislation is an early link in the legislative chain leading to expanded pollution controls and to the present-day Coastal Zone Management Program. There are no standards established by this act nor are there any enforcement mechanisms. The act predates the National Environmental Policy Act of 1969, but it might be described as a similar kind of legislation--a policy-setting (or pre-policy setting) act setting forth the Nation's recognition of the value and importance of its estuarine areas.

The act's provision which requires Federal agency consideration of estuarine impacts when that agency's activities will affect an estuary, has the effect of focusing specific attention on the estuary. This is complementary to NEPA which requires consideration of many environmental concerns, and the Fish and Wildlife Coordination Act which requires consideration of the wildlife resource (e.g., the shellfish itself).

1/ "National Estuary Study," Fish and Wildlife Service, U.S. Department of the Interior, January 1970.

2/ "The National Estuarine Pollution Study," U.S. Department of the Interior, March 25, 1970.

3/ Supra, note 1 . 
7. Commercial Fisheries Research and Development Act of 1964 , P.L. 88-309, 16 U.S.C.A. 779 et seq.

\section{History}

This act was passed in 1964 (1) to stimulate research on and development of commercial fisheries, (2) to develop new commercial fisheries, and (3) to provide relief funds where there has been a commercial fishery failure due to a resource disaster arising from natural or undetermined causes. The legislative history reports testimony of a state commissioner of commercial fisheries that "... we need to know how...productivity has been affected in the past, and might be affected in the future, by overharvesting, by pollution, by use of adjacent lands, and by existing and planned coastal industries."

\section{Purpose}

The purpose of this act is to provide for Federal cooperation in the development of commercial fisheries by supplementing state research and development funds.

\section{Definitions}

"Commercial Fisheries" means any organization, individual, or group of organizations or individuals engaged in the harvesting, catching, processing, distribution, or sale of fish, shellfish, or fish products (Sec. 779), (emphasis added).

\section{Implementation}

Five million dollars is authorized per year for research and development projects. Appropriations are distributed to the 50 states and five territories based on a formula established by the act. Federal funding of as much as 75 percent of the project is authorized, depending on the type of activity and scope of the project.

One and one-half million dollars is authorized per year for projects, with a preference given to states in which there is a commercial fishery failure due to a resource disaster arising from natural or undetermined causes, for any purpose appropriate to restore the affected fishery or to prevent a similar failure in the future. Federal funding is allowed up to 100 percent under this authorization. One hundred thousand dollars is authorized to be made available to states for developing new commercial fisheries. Again, Federal funding of as much as 100 percent is authorized. (Sec. $779(b))$. 


\section{$\underline{\text { Reports }}$}

The Secretary of Commerce is to submit an annual summary of funding activities under the act. II

Comment

It seems clear that monies under this act would be available to study the water quality problem as it affects the shellfish habitat and the associated commercial impacts. Relief funds provided by the act could go toward the restoration of shellfish beds damaged as a result of a "resource disaster of natural or undetermined causes." However, it would appear that relief money would not be available for shellfish habitat damage resulting from a man-made resource disaster such as the loss of shellfish beds because of water pollution.

\section{Anadromous $2 /$ Fish Conservation Act. P.L. 89-304, 16 U.S.C. 757}

\section{History}

This act is a parallel to the Columbia River fishing development program initiated by the Congress in 1938. It extends the focus to anadromous fish of other river basins and to fish that have similar life cycle characteristics in the fresh waters of the Great Lakes.

\section{Purpose}

The purpose of this act is to conserve, develop, and enhance the anadromous fishery resources of the nation, and $f$ ish in the Great Lakes that ascend streams to spawn, that are subject to depletion from water resource developments and other causes including water pollution and predation from the sea lamprey.

\section{Definitions}

\section{(See Footnote 2.)}

\section{Implementation}

The Secretary of Commerce $3 /$ is authorized to enter into cooperative agreements with the states and other non-Federal interests to conduct

1/ See, e.g., "Grants-in-Aid for Fisheries: Program Activities," National

2) Marine Fisheries Service, Department of Commerce, October 1976.

2/ Anadromous fish are an important food fish. The salmon is but one example. They begin their life in fresh water, migrate to salt water, and return to fresh water to spawn.

3/ The act reads "...the Secretary (of the Interior)..." Under Reorganization Plan No. 4 of 1970 , functions carried out by the Secretary of the Interior (Bureau of Commercial Fisheries) were vested in the Secretary of Commerce (National Oceanic and Atmospheric AdministrationNational Marine Fisheries Service). 
investigations, surveys, and research; to construct and maintain fish facilities; and to conduct studies. Into the management of streams and bodies of water for the conservation and enhancement of this valuable fishery resource.

Federal funding is authorized for as much as sixty-six and two-thirds percent of a given project depending on the scope of the project.

This act will expire on June 30, 1979.

\section{Reports}

The Secretary of Commerce, on the basis of studies conducted under this act and under the Fish and Wildlife Coordination Act, $\underline{\text { / }}$ is to make recommendations to the Administrator of the Environmental Protection Agency 2/ "...concerning the elimination or reduction of polluting substances detrimental to fish and wildlife in interstate or navigable waters or the tributaries thereof."

\section{Comment}

The classification "anadromous fish" does not include molluscan shellfish. Nevertheless, it is clear that any efforts that go toward conserving, developing, and enhancing the water quality of the anadromous fish environment will be of benefit to other species, including molluscan shellfish which share that water environment. As the legislative history of an amendment to the act reveals (Senate Report No. 93-892 accompanying P.L. 93-362), most of the coastal and Great Lakes states have participated in the program.

The Administrator's enforcement authority in this regard is contained in FWPCA.

9. Fishery Conservation and Management Act of 1976, P.L. 94-265, 16 U.S.C. 1801 et seq. (June 1976 Supp.)

\section{History}

Passed in 1976, this legislation was highly controversial because it extends the territorial limits of the United States (for fishing purposes) to 200 miles. During the Congressional deliberations, the United States

1/ See accompanying discussion of the Fish and Wildlife Coordination Act (P.L. 85-624), as amended (16 U.S.C. 665).

2/ The act states that these recommendations are to be made to the Secretary of Health, Education, and Welfare. Pursuant to the Reorganization Plan No. 3 of 1970, responsibilities of the Department of Health, Education, and Welfare were transferred to the Environmental Protection Agency. 
was participating in the International Law of the Sea Conference, and it was anticipated that passage of the legislation might hurt the U.S. position at the conference. Additionally, the migratory species fishermen (especially tuna fishermen) who fish in waters off other countries were afraid that other governments might retaliate, thus cutting them out of choice fishing sites off foreign shores. As a result, an exclusion from regulation for "highly migratory species" was made a part of the act.

\section{Purpose}

The purpose of this act is to provide exclusive U.S. overall management of fishery resources in the "fishery conservation zone" consistent with legitimate uses of the high seas. The purposes are (1) to take immediate action to conserve and manage the fishery resources by establishing a fishery conservation zone and (2) to establish an exclusive U.S. fishery management authority.

Although not stated by Congress as a purpose of the act, provision is made in the act for a comprehensive fishery research program designed to further the specific purposes of conservation and management.

\section{Definitions}

"Fish" means finfish, mollusks, crustaceans, and all forms of marine animal and plant life other than marine mammals, birds, and high migratory species. (emphasis added).

"Fishery" means (a) one or more stocks of fish that can be treated as a unit for purposes of conservation and management and that are identified on the basis of geographic, scientific, technical, recreational, and economic characteristics, and (b) any fishing for such stocks.

"Fishery resource" means any fishery, any stock of fish, any species of fish and any habitat of fish.

"Stock of fish" means a species, subspecies, geographic grouping or other category of fish capable of management as a unit.

"Conservation and Management" means all the rules, regulations, conditions, measures, and methods, required to rebuild, restore, or maintain (or are useful to rebuild, etc.) any fishery resource and the marine environment; and that are designed to assure that:

(1) A supply of food and other products may be taken, and that recreational benefits may be obtained, on a continuing basis.

(2) Irreversible or long-term adverse effects on fishery resources and the marine environment are avoided.

(3) There will be a multiplicity of options available with respect to future uses of these resources. 
The term "optimum" with respect to the yield from a fishery, means:

(1) The amount of fish that will provide the greatest overall benefit to the nation with particular reference to food production and recreational opportunities.

(2) The amount of fish that is prescribed as such on the basis of the maximum sustainable yield from such fishery, as modified by any relevant economical, social, or ecological factor.

\section{Implementation}

Eight regional fishery management councils are to be set up for the United States, composed of state and Federal officials and other "qualified individuals" in the areas of conservation, management, and sport and commercial fishing. They are to devise "fishery management plans" for each individual "stock of fish" or "unit" within its boundaries. The plans are to include conservation and management measures applicable to foreign fishing and fishing by United States vessels; the plans also are to assess and specify the present and probable future condition of and the maximum sustainable yield and optimum yield from the fishery.

The plans may also include permit requirements for fishing in the particular fishery management zone, or taking of Continental Shelf fishery resources (including mollusks) beyond the zone; designation of zones where, and periods when, fishing shall be limited; limitations on the catch of fish, and limitations or prohibitions on the use of particular equipment.

The Secretary of Commerce must approve or disapprove a plan within 60 days or develop a plan if the cognizant council fails to produce an adequate plan. If the Secretary develops a plan, the council may review it and suggest modifications.

The Secretary is also required to conduct a comprehensive program of fishery research to carry out and further conservation, management, and other purposes and policies of the act, including research on the impact of pollution on the abundance and availability of marine life (304(e)).

The regulations promulgated pursuant to this act contain a number of important clarifying provisions (see 50 CFR 601 and 602, 41 F.R. 39437, Sept. 15, 1976). First, the plans are "major Federal action" for NEPA purposes, and the Regional Councils must make an environmental assessment to determine if an Environmental Impact Statement is necessary (601.21(b)(1)). Second, the regulations require the Regional Councils to coordinate development of the plans with the provisions of the situs state's Coastal Zone Management Plan required by the Coastal Zone Management Act, 16 U.S.C. 1451 et seq. (This regulation is found at 50 CFR 601.21(b)(3)). The third important provision is that which clarifies the concept of optimum sustainable yield; while the older concept, maximum sustainable yield, focuses primarily on methods of assuring a continuing supply of fish, optimum 
sustainable yield is broader in its scope to include "the economic wel1being of the commercial fishermen, the interests of the recreational fishermen, the fish habitat quality and the welfare of the Nation"

(602.2(B)(3)). Thus a standard based on optimum sustainable yield might well deviate from maximum sustainable yield, if other conditions including the quality of the fish habitat so dictate.

\section{Comment}

The legislative history of this act deals extensively with fish other than shellfish. It may be inferred that the problems of shellfish were not a major consideration in the passage of this legislation, although they are mentioned in the act. To the extent this is true, it will be particularly important to monitor the extent to which activities of the Secretary of Commerce and of the Regional Councils support the interests of shellfish and of the shellfish industry including the problem of habitat water quality. An examination of the makeup of the Regional Councils would be one indicator of the relative concern that could be expected. Another indicator would be the degree to which research funds authorized under the act are expended for study of shellfish habitat problems, including the effects of pollution and degradation of the wetland and estuarine environment.

Fishery management science has traditionally used the "maximum sustainable yield" concept, which asks only the question: How much fish can be taken without affecting the continual replenishment of the stock? This legislation introduces the "optimum sustainable yield" concept, which asks the further question: What other effects must be considered when determining the amount of fish that can (or should) be taken? These other effects include the greatest overall benefit to the Nation in terms of food production; economic effects, social effects, and ecological factors.

In implementing the optimum sustainable yield concept, the Regional Councils develop plans for each "stock of fish," the definition of which includes shellfish. An examination of these plans would determine the extent to which problems with the health of shellfish are covered. These plans are now being drafted. Given the Councils' power to restrict or even suspend fishing of particular species, or in particular areas, there exists the potential capability to control fishery quality problems, although management of the shellfish resource within the three-mile limit would remain a state function.

"Qualified individuals" are to serve on the Regional Councils. These are defined in the act to include persons knowledgeable or experienced with regard to the management, conservation, or recreational or commercial harvest of the fishery resources of the respective geographical areas. This would at least infer representation of the shellfish industry, as well as persons concerned about the relative quality and health of the catch. Substantial control could be expected in light of the Councils' near plenary powers over fishing in their respective areas. 
Overall, the act provides for the exclusive management of fishery resources by the United States (and through the Regional Councils) out to the new 200-mile fishery management zone, or further, to the extent of the Continental Shelf (on which particular mollusks may be found). Such comprehensive management, including ecological considerations, at least has the potential for dealing with the spectrum of problems associated with the shellfish industry, including the water quality issue as it affects shellfish. However, the language of the act, the persons constituting the Councils, and the fact that optimum sustainable yield is still tied to the maximum sustainable yield concept--all lead to an interpretation of the act's language that is much more related to the size and perpetuation of the catch than to either the quality of the catch or the condition of its habitat. Again, the effectiveness of the act in dealing with any problem related to water quality as it affects shellfish will largely depend on the kind of actions taken by and restrictions put forth by the Secretary of Commerce and by the Regional Councils.

10. Water Resources Research Act of 1964, P.L. 88-379, 33 U.S.C.A. 1961 et seq.

\section{History}

The legislative history (House Report No. 88-1136) speaks of "...impending water shortages..." and the need for "...increasing usable water supplies or making more efficient use of present supplies..." The areas in which research is contemplated are tied to the water quantity issue. Examples are:

(1) Reducing reservoir evaporation.

(2) Reducing wasteful irrigation practices and losses due to irrigation water seepage.

\section{Purpose}

The purpose of this act is to expand water resources research to help cope with the "mounting water use problems posed by the projected growth of our population and economy" and to meet the "critical need for additional hydroscientists" (House Report No. 88-1136).

\section{Implementation}

This act establishes water resources research institutes in each state (or through state "compacts") at colleges and universities. Preference is given to the land grant colleges, but others are eligible. They are to research issues discussed above and to plan programs to develop hydroscientists.

The act authorizes the Department of Interior to make grants for research into water problems related to the Department's "mission." 


\section{Enforcement}

The activities of the various institutes and research projects are to be monitored, and there must be checks on the use of funds.

\section{Reports}

There are requirements that each grantee engage in a program of dissemination of its findings. Also, the Secretary is to submit an annual report to Congress on activities funded under the act.

\section{Comment}

This legislation was part of a series of laws dealing with water resource management. It approaches the problem from the standpoint of accommodating water quantity needs associated with population and economic growth; it does not focus directly on water quality. One realizes, however, that there are indirect connections between water resource development and water quality that can affect shellfish, such as the construction of a dam that could affect downstream water flows, with consequences for the ecology of the estuary at the river mouth. It would appear that the act could be used to fund research on these indirect water quality issues.

\section{The Submerged Lands Act, P.L. 83-31, 43 U.S.C. 1301-1315 (1970) and The Outer Continental Shelf Lands Act, P.L. 83-212, 43 U.S.C. $1331-1343(1970)$}

\section{$\underline{\text { History }}$}

These laws grew out of the 1947 Supreme Court decision in United States v. California (322 U.S. 19 (1947)), which held that the Federal Government rather than the states owned the seabed adjacent to the states' coastlines. In 1953 Congress passed the Submerged Lands Act, conveying to the states that portion of the seabed lying seaward from the coast to a distance of three miles. Ownership and control of the seabed from that point seaward (the outer continental shelf) was to remain in the Federal Government. Subsequently, Congress passed the Outer Continental Shelf Lands Act dealing with the leasing and development of that outer continental shelf seabed.

\section{Purpose}

The purpose of this act is to establish hegemony over the respective offshore areas (zero to three miles, three miles ari beyond) in contemplation of development of the oil, gas, and mineral resources of the Nation's continental shelf.

\section{$\underline{\text { Definitions }}$}

The term "natural resources" includes oil, gas, minerals, fish, shrimp, 
oysters, clams, crabs, lobsters, sponges, kelp, and other marine animal and plant life.

\section{Implementation}

Lands and waters extending out to three miles, and the natural resources therein and thereunder, are declared to be in the ownership of the respective states "...to manage, administer, lease, develop, and use...." (43 U.S.C. Sec. 1311). Beyond that three-mile limit, the subsoil and seabed appertain to the Federal Government "... and are subject to its jurisdiction, control, and power...." (43 U.S.C. Sec. 1332). Said Federal power and control includes leasing of the seabed for purposes of developing the oil, gas, and mineral resources therein. The Secretary of the Interior is to conduct the leasing of the seabed on behalf of the Federal Government and is authorized to issue regulations in conjunction with that responsibility.

\section{Reports}

The Secretary of the Interior is to submit an annual report to the Congress that includes a financial accounting of the year's activities vis-a-vis the leasing program.

\section{Comments}

The acts predate the heightened environmental activity of the 1960s and 1970s. Thus it is not surprising to find the Outer Continental Shelf Lands Act stressing oil, gas, and mineral development without significant comment as to environmental concerns. The oil and gas leasing programs have been criticized because of this fact. The Secretary must, however, draft regulations to prevent the waste of natural resources. The Secretary also has the responsibility to take environmental concerns into consideration when he drafts individual leases. Under the provisions of the National Environmental Policy Act of 1969, he must do so:

The Congress authorizes and directs that, to the fullest extent possible: (1) the policies, regulations, and public laws of the United States shall be interpreted and administered in accordance with the policies set forth in this (Act).... (42 U.S.C. Sec. 4332)

Thus, the Secretary's actions in suspending certain outer continental shelf oil leases following the Santa Barbara oil spill were upheld by the court:

The Secretary has full authority to reconcile objectives of this chapter (Outer Continental Shelf Lands Act) and the National Environmental Policy Act by regulating drilling under government leases with an eye to the protection of the environmental quality of the continental shelf. (Union 0il Co. of Calif. v. Morton, 512 F.2d 743, C.A. Ca1. 1975.) 
And in a similar case:

This chapter (Outer Continental Shelf Lands Act) authorizes the Secretary of the Interior to suspend operations under existing leases whenever he determines that risk to the marine environment outweighs immediate national interest in exploring and drilling for oil and gas. (Gulf Oil Corp. v. Morton, 493 F.2d 141, C.A. Cal. 1974.)

The provision cited by the court so authorizing the Secretary is found in the language of the act stating that the Secretary's rules and regulations must "...provide for the prevention of waste and conservation of the natural resources of the outer continental shelf...." (43 U.S.C. 1301 (e)(2)(3).) The court then referred back to the act's comprehensive definition of natural resources which, as noted above in the "definitions" section, includes fish, shrimp, oyster, etc., as well as the oil, gas, sulphur, and mineral resources.

The Federal leasing program as a major Federal program affecting the environment, comes under the National Environmental Policy Act requirement that an environmental impact statement be written. This allows for a review of the likelihood and degree of possible negative consequences for the environment. However, the magnitude of the leasesale areas presently considered under the EIS is very large. This makes it difficult for agencies responsible for marine resources to treat impacts with specificity.

Finally, it should be noted that the Federal consistency requirement under the Coastal Zone Management Act of 1972 requires that activities conducted by the Federal Government be coordinated with and consistent with the state's approved management plan for its coast. This requirement would apply to the Federal Government's leasing program, especially as it affects the state's water quality and land use planning. Virtually all off shore drilling requires substantial shore-based support which can, in turn, have a negative effect on the water quality of proximate shellfish beds.

\section{Deepwater Port Act of 1974, P.L. 93-627, 33 U.S.C. 1501 et seq.}

\section{History}

The shipping of oil will increase when Alaskan oil becomes available. New large crude-carrying vessels from the mid-East and from Alaska will require water depths of up to 100 feet for safe operation. Because of the advantages of off-loading such vessels "at sea" and bringing in their product via pipelines for subsequent handling ashore, Congress established a program to govern the construction and operation of offshore deepwater ports. Environmental advantages put forth in the legislative history accompanying the act (Senate Report No. 93-1217) are that deepwater ports will reduce the risks of groundings, collisions, and oil spills. 


\section{Purpose}

The purpose of this act is to authorize and regulate deepwater ports and to protect the marine and coastal environment by preventing or minimizing any adverse impact that might occur as a consequence of the development of such ports.

\section{$\underline{\text { Definitions }}$}

"Coastal state" (adjacent coastal state) means a state (1) where the pipeline first comes ashore, or (2) that is within 15 miles of the deepwater port or its pipelines, or (3) that bears substantial risk of serious damage to its coastal environment from an oil spill associated with the deepwater port.

"Coastal environment" includes transitional and intertidal areas such as bays, lagoons, salt marshes, estuaries and beaches. The term also includes fish, wildlife and other living resources.

"Marine environment" includes the coastal environment, waters of the contiguous zone and waters of the high seas; the fish, wildlife and other living resources of such waters; and the recreational and scenic values of such waters and resources.

A "deepwater port" is defined as a "new source" for purposes of FWPCA. As such it would be subject to standards of performance established by EPA pursuant to Section $306(a)$ of FWPCA.

\section{Implementation}

To construct and operate a deepwater port, a license must be obcained from the Secretary of the Department in which the Coast Guard is operating (presently the Department of Transportation). There are a number of prerequisites to the granting of a license, several of which relate directly or indirectly to the issue of water quality:

o The Secretary must find that the deepwater port would be...consistent with...environmental quality,

o The Secretary must determine that...the deepwater port will utilize the best available technology so as to prevent or minimize adverse impact on the marine environment. Environmental criteria must be consistent with NEPA, and ....(a) single detailed environmental impact statement must be prepared,

- EPA must have an opportunity to adjudge whether or not the deepwater port will conform with provisions of the Clear Air Act, FWPCA, and the Marine Protection, Research and Sanctuaries Act, 
- The Secretary may not issue a license unless the Governor of any adjacent coastal state has approved the proposed port (i.e., the Governor has a veto power over the project). There is room for negotiation here: the Secretary may agree to conditions requested by the Governor that would bring the project more in line with particular state concerns such as water quality.

The Act calls upon the Secretary to establish regulations relating to cleanup of pollution discharges. Where a spill occurs, the act attaches strict liability to owners/operators of a vessel that discharges oil or natural gas into the marine environment and to a deepwater port licensee where the port facility itself does the discharging. Over and above these sources of recovery, the act establishes a Deepwater Port Liability Fund to assure that no one harmed by a related spill is left uncompensated. The Attorney General is authorized to file suit on behalf of citizens harmed by a discharge from the port's operation.

Upon request of a state, and after having received recommendations from NOAA, the Secretary is to designate that state as an "adjacent coastal state" if he determines that there is a risk of damage to its coastal environment equal to or greater than the risk posed to a state directly connected by pipeline to the proposed deepwater port.

The Secretary is to consult with NOAA when preparing regulations relating to site evaluation and preconstruction testing where such activity would (1) adversely affect the environment, (2) interfere with authorized uses of the Outer Continental Shelf, or (3) pose a threat to human health and welfare.

The Secretary is to consult with EPA, NOAA, and other Federal agencies to establish environmental review criteria consistent with NEPA to be used in evaluating deepwater port applications. These criteria shall include, in part:

(1) The effect on the marine environment

(2) The effect on fishing

(3) The effect on human health and welfare.

\section{Reports}

of interest is an annual report required to be submitted by the Secretary to the President of the Senate and the Speaker of the House that (1) inventories all deepwater port development; (2) offers a summary of management, supervision, and enforcement activities; and (3) makes recommendations for new legislative authority where needed.

The act also calls for a study by the Department of Justice on the need for uniform oil spil1 liability legislation covering all sources of oil pollution, not solely deepwater ports. 
There is an inevitable tension between the national need for the petroleum these deepwater ports will handle and the likelihood of environmental harm, including water quality degradation. Quoting from the Senate Report (No.93-1217):

"...anticipated environmental impacts include (inter alia)...

Degradation and despoliation of wetlands, estuarine areas, wildlife habitats and recreation values; and...

Increased potential for air and water pollution...."

The report also recognizes the catastrophic damage that would follow the breakup of an oil tanker in heavy seas a few miles off our seacoast. offshore areas are susceptible to severe storms and winds, that could damage both ships and deepwater ports. In terms of harm suffered by a nearby shellfish industry, long-term losses might go uncompensated. Cleanup costs following a spill would fit neatly into the act's liability provisions and would be obvious. However, as the report states, "... damage to resource values are less easily quantified and may go unperceived for some time following a polluting event." Subtle and long-term poisoning of a seabed from minor leaks or bilge discharges will likely be considered in the requisite environmental impact statement, but that consideration alone will not be sufficient to ameliorate the harm. The fact that a deepwater port facility must comply with FWPCA discharge criteria does not mean that there will be no violations, accidental or otherwise; hence the liability provisions. A shellfish industry that has suffered because of a water quality reduction, whether catastrophic or long-term, might well not be satisfied with money damages. Unfortunately, injunctive relief is moot in the case of a catastrophic spill, and would be difficult to obtain in the case of subtle, long-term water quality degradation.

13. The National Environmental Policy Act of 1969, P.L. 91-190, 42 U.S.C. 4321-4347(1970)

\section{History}

The 10-year period leading up to the passage of the National Environmental Policy Act (NEPA) had witnessed increasing pressures on the environment from population growth, high-density urbanization, industrial expansion, resource exploitation, and complex technological change. A need was evident for a coordinated approach to deal with the environmental consequences of these pressures. 1969 was to be the year of action. The House Bill (H.R. 6750, 91st Cong., 1st Sess. (1969)) provided for a Council on Environmental Quality with an oversight responsibility. The Senate bil1 (S.1075, 91st Cong., 1st Sess. (1979)) went so far as to give every citizen a healthful environment as a matter of right. The Senate bill also was the only one to contain the requirement for an environmental impact statement (EIS). In conference, the right to a healthful environment was deleted and the requirement for an EIS was 
found acceptable by the House. The final version was passed by both Chambers in the third week of December 1969, and was signed into law on January 1, 1970 .

\section{Purpose}

The purposes of this act are (1) to establish a policy that will encourage harmony between man and his environment, to prevent or eliminate damage to the environment and biosphere, and to enrich the understanding of the Nation's ecological systems and natural resources; and (2) to establish a Council on Environmental Quality.

\section{Implementation}

The policy declared in the act is that all practicable means and measures shall be used "...to create and maintain conditions under which man and nature can exist in productive harmony, and fulfill the social, economic, and other requirements of present and future generations of Americans." The act directs that, to the fullest extent possible, policies, regulations, and laws of the United States are to be interpreted and administered in accordance with this declaration.

Agencies of the Federal Government are to broaden their planning and decision-making; they must include a statement of the following factors in every recommendation or report on proposals for legislation and other major Federal actions: (Sec. 102(2)(c).)

o The environmental impact of the proposed action.

o Adverse environmental effects that cannot be avoided should the proposal be implemented.

- Alternatives to the proposed action.

o The relationship between local short-term uses of the environment and the maintenance and enhancement of longterm productivity.

- Irreversible and irretrievable commitments of resources that would be involved.

The compilation of this information has become known as the environmental impact statement (EIS).

The act also creates a Council on Environmental Quality with a general monitoring, research, and policy-formulating role in environmental matters. One Council function is to assist the President in preparing an annual report to Congress to include, in part, the status and condition of the aquatic environment--marine, estuarine, and fresh water. The Council is also encouraged to recommend legislation, where appropriate. 
To assist in the preparation of EIS's, the Council has issued guidelines for the interpretation of the act's requirements in regard to:

- Circumstances that require filing of an EIS

- The precise contents of the Statement

- Procedures for preparation and filing. 1 /

Much litigation has taken place in an attempt to satisfactorily define the meaning of such expressions as "to the fullest extent possible"; "major... actions"; "Federal actions"; "actions significantly affecting...the environment"; "a detailed statement"; "environmental impact"; "environmental effects"; "alternatives"; etc. The hoped for definitions are elusive--a court answers to definitional questions on a case-by-case basis, generally referring back to the policy goals stated in the act and using common sense to review the relevant facts of the case before it. Thus an action is a "major action" if the court decides that it is. 2 /

\section{Enforcement}

The act contains no enforcement mechanism. As a result, "enforcing" the goals of the act and oversight of the EIS filing requirement have devolved to environmental public interest groups who have engaged in extensive litigation in this regard.

\section{$\underline{\text { Reports }}$}

An annual Environmental Quality Report is to be sent to Congress to include the following:

- Status and condition of the Nation's environmental resources.

o Trends in the quality, management, and utilization of the resources.

- Adequacy of available natural resources for fulfilling the Nation's human and economic requirements.

1/ 40 C.F.R.Sec. 1500.1 et seq., issued pursuant to Executive Order No. 11514 of March 5, $\overline{19} 7 \overline{0}$.

2/ In referring to the language of the act, a New York Federal District Court remarked that it would be difficult to conceive of statutory terms larger, looser, or more cloudy. 
o An across the board review and assessment of programs and activities (Federal/state/local governments;

private sector) affecting the environment.

- A program for remedying deficiencies, including recommendations for new legislation where needed.

\section{Comment}

This act is, as its name indicates, a policy act. It is important that the policy goals contained in the act are there for the Federal Government to consider as it conducts its day to day activities. At the Federal level, agency consideration of the act's goals is to be assured by the requirement that an EIS be prepared for proposed major projects that have a significant impact on the human environment. As mentioned above, however, the act has no enforcement mechanism. The Council on Environmental Quality has no power to order an agency to do anything. It has no line responsibility in the Nation's environmental affairs and has no authority to supervise or to intervene in agency regulatory activities. It does coordinate the interagency review provided under the act. It also monitors the EIS process and makes comment in its annual report.

In the area of water quality, the Federal Water Pollution Control Act (FWPCA) relieves agencies of any obligation to review effluent limitations or impose any stricter discharge standards as part of a NEPA assessment. (33 U.S.C. Sec. 1371(c)(2).) Furthermore, FWPCA also removes actions taken by the EPA Administrator pursuant to FWPCA from the EIS requirements of NEPA--i.e., the Administrator's FWPCA actions are statutorily deemed not to be a major Federal action significantly affecting the quality of the human environment. There are two important exceptions, however; (1) Federal assistance for the purpose of constructing publicly owned treatment works, and (2) effluent discharge permits issued for new point source discharges. These actions are still deemed to be major Federal actions requiring the filing of an EIS. Such an EIS would presumably deal with any negative water quality impacts on shellfish habitat where such impacts would occur.

A further--and critical--observation about NEPA is that once the requirement is satisfied for the drafting of an EIS, the proposed project can proceed. The theory is that the work proceeds with full knowledge of associated negative impacts, that mitigative measures, where possible, have been taken (though not compulsory), and that alternatives have been considered and rejected. There is positive effect for the shellfish environment insofar as constructive comment produced by the interagency review process is considered and insofar as negative impacts revealed by the EIS process create politically organized resistance at a level sufficient to modify or halt the project where appropriate.

Even as a planning tool vis-a-vis the quality of the shellfish environment, NEPA has shortcomings. This is because the focus of the EIS review is on the impacts of the case at hand, and not on the larger issue of how the case relates to cumulative local, regional, and national problems 
and needs. For example, a proposed siting of a U.S. Navy ship repair facility on a bay would result in consideration of associated impacts in accordance with NEPA. But the facility may or may not be in the best interests--from a planning standpoint--of the local community, the region, or the state. If that bay were a particularly valuable spawning ground, or fishery, how would the "national need" for a military ship repair capability be compared to local commerical fishing interests? The Coastal Zone Management Act, as amended, would help coordinate this kind of planning, but NEPA would not, by itself, meet the issue, other than revealing that there is this conflict.

Again, NEPA protects the shellfish environment to the extent that private groups (environment/industry) and government agencies with responsibilities for the resource act as watchdogs of Federal actions to ensure that environmental impacts of proposed projects are inventoried; and that alternatives to the project and/or ameliorative actions are considered.

14. Coastal Zone Management Act of 1972, P.L. 92-583, 16 U.S.C. 1451 et seq.

\section{History}

In 1966, the 89 th Congress created the Commission on Marine Science, Engineering, and Resources. This commission issued a report entitled "Our Nation and the Sea" recommending the passage of Federal coastal zone management legislation. Several bills were subsequently proposed, including S.3183. This particular bill was derived from recommendations of the Department of the Interior in its National Estuary Study (performed pursuant to the Estuarine Areas Act, P.L. 90-454). The legislative history accompanying S.3507, the bill which finally became law, acknowledges that coastal and estuarine waters and marshlands are vital for several reasons, including the provision of nutrients, nursing areas, and spawning grounds.

\section{Purpose}

The purpose of this act is to effectively manage the Nation's rich coastal zone, recognizing it as a resource of many values:

o Natural

- Commercial

o Recreational

o Industrial

o Aesthetic

Management power and authority is placed at the state level, with the Federal Government establishing standards and playing a coordinating

$$
\text { B-44 }
$$


role, and with Federal agencies cooperating insofar as those agencies carry out activities in or related to the coastal zone. Thus, permits, licenses, and financial assistance from Federal agencies are to be consistent with approved state coastal zone management plans.

The act specifically recognizes that fish, shellfish, and other living marine resources are ecologically fragile and therefore vulnerable to the activities of man.

\section{Definitions}

"Coastal zone" means coastal waters (including the lands therein and thereunder) and the adjacent shorelands. Included also are Great Lakes waters.

"Management program" includes a comprehensive statement in words, maps, illustrations (etc.) setting forth objectives, policies, and standards to guide public and private uses of lands and waters in the coastal zone.

"Water use" means activities conducted in or on the water; it does not mean or include the establishment of any water quality standard or criteria or the regulation of the discharge or runoff of water pollutants. This aspect is to be handled within the Federal Water Pollution Control Act, and standards and controls thereunder are to be incorporated into the management program.

\section{Implemention}

With Federal matching money available for planning, each coastal state (including the Great Lakes states) is to draft a management program for the land and water resources of its coastal zone. Furthermore, Federal money is available on a matching basis to meet the costs of administering the state's management program.

\section{Oversight}

The State programs are submitted to the Secretary of Commerce for approva1. (As pointed out in the Senate Report (92-753) accompanying the act, there could be, in theory, 35 substantially different management programs.) The Secretary conducts a continuing review of the management programs and of the performance thereunder. A Coastal Zone Management Advisory Committee is established to advise, consult with, and make recommendations to the Secretary on methods of policy concerning the coastal zone.

\section{$\underline{\text { Reports }}$}

The Secretary is to submit a report annually (by November 1 of each year) to the President for transmittal to the Congress. The report is to list, inter alia, programs approved and problems encountered in administering the act. 
The act specifically looks to existing pollution control legislation for controlling that aspect of the coastal zone management problem. It is true, however, that local zoning and general planning--conducted in the spirit of the act--would indirectly affect pollution levels in a given location by the degree and kind of development authorized. The act, at least, would seem to result in a more conscious balancing of the gains and losses associated with such a decision.

\section{Coastal Zone Management Act Amendments of 1976, P.L. 94-370}

\section{History}

Within its concern for responsible coastal zone management, the Federal Government found the need for responsible handling of energy related activities along the coast. The concern is related to a postOPEC-boycott drive for energy self-sufficiency, and recognizes that the coastal zone will be significantly involved in such a drive.

The legislative history of the original House bill (Report No.994-878 on H.R. 3981) shows that the purpose of a molluscan shellfish study $1 /$ called for in P.L. $94-370$ is to have a review of all aspects of the shellfish industry to determine if additional regulations should be imposed upon that industry by the Food and Drug Administration.

\section{Purpose}

The purpose of this act is to provide assistance to the coastal states to study, plan for, manage, and control and impact of energy resource development and production that affects the coastal zone.

\section{$\underline{\text { Definitions }}$}

"Coastal energy activity" includes generally any outer continental shelf energy activity; any transportation, conversion, treatment, transfer, or storage of liquefied natural gas; and any transportation, transfer, or storage of oil, natural gas, or coal.

"Energy facilities" include generally:

- Electric power generating plants

- Petroleum refineries

- Gasification plants

- Nuclear fuel facilities

I/ Of which this review of laws is a part. 
o $\quad 0 i 1$ and gas facilities

o Petroleum transfer facilities

Implementation

Assistance is provided to the coastal states in the form of grants or loans from a newly established Coastal Energy Facility Impact Fund. Money is provided for planning and for reducing, ameliorating, or compensating for negative impacts resulting from the energy facility or resource deve1opment activity.

Included in these amendments is the aforementioned requirement for a special study of the molluscan shellfish industry by the Secretary of Commerce.

\section{Reports}

of interest to the water quality issue and the shellfish industry is an addition to the Secretary of Commerce's reporting requirements under the Coastal Zone Management Act Amendments of 1972. This is the requirement that he or she include in the report a description of the economic, environmental, and social consequences of energy activity affecting the coastal zone and an evaluation of the effectiveness of Federal financial assistance in dealing with such consequences.

\section{Comment}

This act admits the inevitability of increased coastal energy related activity, and it recognizes that there will be substantial impacts on the coastal zone including impacts on water quality. Where negative impacts cannot be ameliorated, the act contemplates the payment of compensation. For example, payment might go to compensate for individual shellfish industry losses resulting directly from coastal energy activities (where such losses can be tied to said activity). Water pollution associated with periodic spills or seepages might result in this kind of situation.

16. Water Resources Planning Act, P.L. 89-80, 42 U.S.C. Sec. 1962 et seq.

\section{History}

A six-year effort to pass comprehensive water resources and river basin planning legislation culminated in the enactment of this legislation in 1965. The major barriers to previous bills were lack of assurance of an adequate state role vis-a-vis the Federal Government and a concern that ongoing planning bodies would be displaced even if they were functioning effectively.

An important aspect of this legislation was the stated concern for water quality as we11 as quantity. Then Secretary of HEW Cohen, in his 
letter of support for the bill, said it would be a vehicle for coordinating HEW's programs of water pollution control with water resources planning.

\section{Purpose}

The purpose of this act is to encourage conservation and to develop the Nation's water and related land resources through sound, comprehensive, and coordinated planning by:

(1) Establishing a cabinet-level Water Resources Council.

(2) Authorizing the President to establish river basin planning commissions when and where needed.

(3) Providing financial assistance to states for water resources planning.

\section{Implementation}

Section 101 establishes a Water Resources Council composed of:

(1) A chairman designated by the President.

(2) Secretaries of the Interior, Agriculture, Army, Commerce, HUD, Transportation, (and HEW, prior to 1975 Amendment).

(3) Administrator of EPA (since 1975).

(4) Chairman of Federal Power Commission.

(5) Other agency heads as deemed appropriate.

The duties of the Water Resources Council are to study and prepare a biennial assessment of the adequacy of water supplies to meet requirements in each region and the national interest; and to relate river basin plans to other water resources related programs and policies (Sec. 102).

The Council is to adopt principles, standards, and procedures for developing river basin plans (Sec. 103) and to review plans submitted by river basin commissions with regard to:

o The plan's efficacy.

o "The effect of the plan on the achievement of other programs for the development of agricultural, urban, energy, industrial, recreational, fish and wildlife, and other resources of the entire Nation..." (emphasis added), (Sec. 104).

Recommendations (following review) for project funding pursuant to the plan are a Presidential duty, delegated to the Director of the Office of Management and Budget by Executive Order. 
The President is authorized to establish river basin water and related land commissions ("commissions") upon request of the Council or a state, for any defined river basin or group of related river basins. The commissions include a Federal chairman, representatives of Federal agencies having a "substantial interest," a representative of each state lying in included basins, and representatives of interstate compacts or international commissions created by treaty (Sec. 201).

These commissions are to carry out the purposes of the act, create water resources development plans, and report annually to Congress (Sec. 204).

Five million dollars is authorized annually for grants to states on a one-to-one matching basis to fund continuous planning and to implement plans.

In 38 Federal Register 24777 (September 10, 1973), the Water Resources Council issued "principles and standards" for development of plans.

These "principles and standards" attempt to accomplish two possibly competing objectives:

- To enhance national economic development and improve national economic efficiency.

- To enhance the quality of the environment by management, conservation, restoration, or improvement of the quality of certain natural and cultural resources and ecological systems.

Alternative plans are to be devised under the act and are required to include complete displays or accounting of relevant beneficial and adverse effects of these two objectives (38 F.R. 24781).

(1) Among the environmental quality effects of the proposed plan to be displayed are those on:

o Open and green space, wild and scenic rivers, lakes, beaches, shores, mountains and wilderness areas, estuaries, and other areas of natural beauty. (emphasis supplied).

- Selected ecological systens.

o The quality of water, land, and air resources.

- Irreversible commitments of resources to future uses.

(2) Special consideration is directed to estuarine areas, fish and wildife habitat, and the harmonizing of land and water use objectives with conservation (38 F.R. 24795). 
(3) Plans may include specific measures for "enhancing the fish and wildlife resources and associated opportunities for the direct harvesting of fish and game as a commercial product," including assessment of values of future production with and without the plan (38 F.R. 24805).

(4) Estuaries are specifically listed as areas for which beneficial effects of water resources management should be considered. Their importance for the harvesting of marine resources, and for the support of marine ecosystems is noted. The biological significance of the estuaries is to be stated (naming species), and effects of the plan on estuaries are to be evaluated (38 F.R. 24811).

(5) The plan's relationship to the water quality goals of the Federal Water Pollution Control Act, and state standards developed pursuant thereto are to be assessed (38 F.R. 24814).

(6) Plans to be developed are of three types or levels (38 F.R. 24824):

- Level A--"Framework studies and assessments" to make broad evaluations, appraisals, and recommendations for further study.

- Level B--"Regional or river basin plans" are "reconnaissance-level evaluations" of water and land resources for an area. They are to resolve long-range problems, focus on "middle term" needs and desires, and identify and recommend action plans and programs.

- Level C--"Implementation studies" are to assess the feasibility of Level A or B plans and set the stage for implementing them.

(7) The FWPCA Amendments of 1972 directed the President, through the Water Resources Council, to complete Level B plans for all basins in the United States by January 1, 1980 (Sec. 209).

(8) The display methods of developing plans under the Water Resources Planning Act by accounting for economic and environmental objectives are held adequate to satisfy the purposes of NEPA (38 F.R. 24869).

\section{Comment}

Water resources planning traditionally concerned itself with maximizing the availabiluty of water according to needs. Planning did not extend beyond a particular program or project. This act sought to extend planning over time and to include concerns of water quality and environmental protection.

Shellfish are not specifically treated by the act. However, they would be considered "fish", or part of the marine environment of estuaries, or as part of an estuary's "biological significance" to bring them into the act's purview. 
The extensive "principles and standards" developed pursuant to the act anticipate a very precise method of evaluating tradeoffs. In this sense, it could be expected that the act would provide a vehicle for assessing the effects of water resource projects on up-river and estuarine water quality directly, and the effect on shellfish somewhat less directly. 

Appendix C

CONTACTS AND INTERVIEWS 

Appendix C

CONTACTS AND INTERVIEWS

BY

Stanford Research Institute

Allen, George

U.S. Army Corps of Engineers

Planning Division

Atlanta, Georgia 30300

404/285-6043

Allen, Harry

U.S. Environmental

Agency, Region II

Water Division

26 Federal Plaza

New York, New York 10007

212/264-1463

Amson, Jonathan

U.S. Environmental Protection Agency

Criteria and Standards Division

Marine Activities Branch

Washington, D.C. 20460

202/245-3039 (Phone Contact)

Anderson, James

Food and Drug Administration

3032 Bryan Street

Dallas, Texas 75204

214/749-2733

Baldacchino, Nell

U.S. Fish and Wildlife Service

1825 B Virginia Street

Annapolis, Maryland 21401

301/269-5448

Bartel, Kenneth

Compliance/Planning Section

Environmental Resources

P.O. Box 2063

Harrisburg, Pennsylvania
Baxter, Linda

U.S. Army Corps of Engineers

Environmental Assessment Division

New York District

Bender, Michael

Virginia Institute of Marine Science

Gloucester Point, Virginia 23690

804/642-2111

Beswick, Ralph

Washington Department of Natural Resources

Public Land Building

Olympia, Washington 98504

206/753-1935

Bigham, Glenn

U.S. Environmental Protection Agency, Region VI

Dallas, Texas 75202

$214 / 349-2142$

Bishop, Charlie

Department of Health and Human Resources

Office of Health Service and Environmental Quality

Bureau of Environmental Services P.0. Box 60630

New Orleans, Louisiana 70160

504/568-5100

Blogoslawski, Walter

National Marine Fisheries Service

Northeast Fisheries Center.

Milford Laboratory

Milford, Connecticut (Letter

Comments) 
Bonchonsky, Michael

U.S. Environmental Protection Agency, Water Division

26 Federal Plaza

New York, New York 10007

212/264-4296

Boyd, Joyce

U.S. Environmental Protection Agency

Monitoring and Data Support

Division

Washington, D.C. 20460

202/426-7792 (Phone Contact)

Bruce, Dave

Louisiana State Department of Health

New Orleans, Louisiana

Bulter, Bill

U.S. Environmental Protection Agency, Region I

JFK Federal Building

Boston, Massachusetts 02203

Campbe11, Robert

U.S. Environmental Protection Agency

National Enforcement Investigations

Center

Office of Enforcement

Denver, Colorado (Phone Contact)

Casper, Victor

Food and Drug Administration

Shellfish Consultant

500 S. Ervay Street

Suite 470-B

Dallas, Texas 75204

214/749-3951

Champ, Michael

Biology Department

American University

Washington, D.C. 20016

202/688-2091
Chica, Bill

Maryland Department of Natural

Resources

Water Resources Administration

Water Permit Section

Tawes State Office Building

Annapolis, Maryland 21401

Clem, J. David

U.S. Food and Drug Administration

Shellfish Sanitation Branch

$\mathrm{HFF}-417$

200 C Street, S.W.

Washington, D.C. 20204

202/245-1557

Collin, George

U.S. Environmental Protection Agency

South Area Operations Branch

1412 Peachtree Street

Atlanta, Georgia 30300

Corelli, Charles

U.S. Army Corps of Engineers

Seattle, Washington

206/753-6887 (Phone Contact)

Coulter, James

Maryland Department of Natural Resources

Tawes State office Building $\mathrm{C}-4$

Annapolis, Maryland 21401

Courson, Robert

U.S. Environmental Protection Angency, Region $\mathrm{X}$

Surveillance and Analysis Division 1200 6th Avenue

Seattle, Washington 98101

206/442-1106

Couture, Pete

National Marine Fisheries Service 14 E1m Street

Gloucester, Massachusetts 01930 
Crawford, Robert

Resource Development and Support Division

Office of Federal and State Relations

Capital Building, Room 150

Charleston, West Virginia 25305

Critchlow, Gale

Division of Fish, Game and Shellfisheries

P.O. Box 1809

Trenton, New Jersey 08625

609/292-2083

Cummings, Joseph

U.S. Environmental Protection Agency

Manchester Laboratory Site

P.0. Box 283

Manchester, Washington 98353

206/478-7666

DeLuise, Frank

U.S. Fish and Wildlife Service

Patchogue, New York

516/475-3434

Dice, Steve

U.S. Army Corps of Engineers

Seattle, Washington

206/221-3628

Douglas, James

Marine Resources Commission P.0. Box 756

Newport News, Virginia 23607

805/245-2811

Dow, Robert

Department Marine Resources

West Boothbay Harbor, Maine 07538

207/289-2291
Duke, Thomas

U.S. Environmental Protection Agency

Sabine Island Marine Laboratory

Gulf Breeze, Florida 32561

904/932-5311

\section{Dunsavage, Peter}

U.S. Environmental Protection Agency, Region VI

First International Building

1201 Elm Street

Dallas, Texas 75270

Dupee, Dave

U.S. Army Corps of Engineers

New England Division

424 Trapelo Road

Building 113 North

Waltham, Massachusetts 02154

617/894-2400

Eisele, William

Shellfish Control

State of New Jersey

P.0. Box 2809

Trenton, New Jersey 08625

609/292-0566

E11iot, Bruce

U.S. Environmental Protection

Agency, Region VI

First International Building

$1201 \mathrm{E} 1 \mathrm{~m}$ Street

Dallas, Texas 75270

214/749-1983

Ferrazzuolo, Richard

U.S. Environmental Protection

Agency, Region IV

1421 Peachtree Street

Atlanta, Georgia 30300

404/526-5289 
Fox, Bill

U.S. Environmental Protection Agency

Criteria and Standards Division

West Tower, 401 M Street, S.W. Washington, D.C. 20460

202/245-3044

Furst, Charles

U.S. Environmental Protection Agency, Region IV

1421 Peachtree Street

Atlanta, Georgia 30300

Gagliardo, Michael

Maryland Department of Natural Resources

Water Resources Administration

Tawes State Office Building D-2

Annapolis, Maryland 21401

301/269-2221

Garreis, Mary Jo

Shellfish Consultant

Maryland Department of Health and

Mental Hygiene

129 Swernway Road

Arnold, Maryland 21012

Geiger, David

U.S. Army Corps of Engineers

Environmental Resources Branch

P.0. Box 2946

Portland, Oregon 97208

503/221-6437 (Phone Contact)

George, Harry

Maryland Department of Natural

Resources

Natural Resources Police

Tawes State Office Building

Annapolis, Maryland 21401

301/269-2249

Givins, Dale

Louisiana Stream Control

Commission

Louisiana State University

Baton Rouge, Louisiana

504/389-5309
Goggins, Phil

Department Environmental Protection

State House

Augusta, Maine 04333

Goldfine, Neil

Department of Environmental

Protection

Division of Water Resources

P.0. Box 2809

Trenton, New Jersey 08625

Grahm, Doug

U.S. Army Corps of Engineers

P.0. Box 1229

Galveston, Texas 77553

713/763-1211

Griffith, Robert

Alabama Department of Public Health

State Office Building

Montgomery, Alabama 36130

205/832-3175

Ha11, John

National Marine Fisheries Service P.0. Box 4218

Panama City, Florida 32401

904/234-5061

Hammond, Frank

Maryland Department of Natural Resources

Water Resources Administration

Tawes State Office Building D-3

Annapolis, Maryland 21401

301/269-3871

Hannesschlager, Robert

U.S. Environmental Protection Agency, Region VI

First International Building

1201 Elm Street

Dallas, Texas 75270

214/749-2625 
Haven, Dexter

Virginia Institute of Marine

Science

Gloucester Point, Virginia 23062

804/642-2111

Hays, Max

Department of Social and Health Services

Environmental Health Program

Food and Housing Section

Airport Complex Building IV

MS-4-1

Olympia, Washington 98504

206/753-5962

Heinen, Edward

U.S. Environmental Protection Agency, Region IV

Ecological Review Branch

1421 Peachtree Street

Atlanta, Georgia 30300

Hodges, John

National Marine Fisheries Service

Environmental and Technical Services Division

P.0. Box 4332

Portland, Oregon 97208

$503 / 234-3361$

Houck, George

Department of Ecology

Water Quality Management Section

Olympia, Washington 98504

503/234-3361

Hurst, John

Department of Marine Resources

W. Boothbay Harbor, Maine 07838

207/633-5572
Jackson, Kenneth

U.S. Army Corps of Engineers

New England Division

Permits Branch, Operations Division

424 Trapelo Road

Building 113 North

Waltham, Massachusetts 02154

$617 / 894-2400$

Janis, James

U.S. Environmental Protection

Agency

Program Evaluation Division

PM 222 Room 1017 West Tower

401 M Street, S.W.

Washington, D.C. 20460

202/755-0340

Johnson, Robert

U.S. Environmental Protection Agency

Criteria and Standards Division

West Tower

401 M Street, S.W.

Washington, D.C. 20460

202/245-3042

Kerver, Jim

Louisiana State Department of

Health

New Orleans, Louisiana

Kidd, De11

U.S. Army Corps of Engineers

New England Division

424 Trapelo Road

Building 113 North

Waltham, Massachusetts 02154

Kinerva, Roger

Maryland Department of Natural

Resources

Tawes State Office Building

Annapolis, Maryland 21401

301/269-3558 
King, Charlie

Department of Environmental

Protection

Water Pollution Control Board

State House

Augusta, Maine 04333

207/289-2558

Klesh, William

U.S. Army Corps of Engineers

Environmental Analysis Branch

P.0. Box 1715

Baltimore, Maryland 21203

301/962-2558

Krantz, George

University of Maryland

Horn Point Environmental

Laboratory

Cambridge, Maryland 21613

301/228-8200

Lee, Walter

U.S. Environmental Protection

Agency, Region III

Curtis Building

6 th and Walnut Street

Philadelphia, Pennsylvania 19106

215/597-3658 (Phone Contact)

Lindsay, Cedric

Department of Fisheries

Shellfish Program

1115 General Administration

Building

Olympia, Washington 98504

206/753-6749

Livingston, Robert

Florida State University

Department of Biological Science

Tallahassee, Florida

904/644-1466

Lyman, Robert

U.S. Army Corps of Engineers

P. 0. Box 17300

Fort Worth, Texas 76102
Macmillan, Bruce

Department of Environmental

Conservation

Marine Environmental Control

Building 40

State University of New York

Stony Brook, New York 11790

McGinnis, Frank

Virginia Seafoods

Irvington, Virginia (Phone Contact)

Marlar, John

U.S. Enviromental Protection

Agency, Region IV

Water Division

1421 Peachtree Street

Atlanta, Georgia 30300

Marsha11, Howard

U.S. Environmental Protection Agency

Region IV

Ecological Review Section

1421 Peachtree Street

Atlanta, Georgia 30300

Mattis, Gene

U.S. Environmental Protection Agency Region III

Water Program Division

Philadelphia, Pennsylvania 19106

215/597-8745

Matuszeski, Bill

National Oceanic and Atmospheric Administration

Office of Coastal Zone

Management

3300 Whitehaven Street, N.W.

Washington, D.C. 20235

202/634-4235

Mantzaris, Christopher

National Marine Fisheries Service

Environmental Assessment Division

Gloucester, Massachusetts 01930

$617 / 281-3600$ 
McElroy, Kenneth

Maryland Department of Natural Resources

Water Resources Administration Planning Division

Tawes State Office Building

Annapolis, Maryland 21404

McErlean, Andrew

U.S. Environmental Protection Agency

401 M Street, S.W.

Washington, D.C. 20460

202/755-0638 (Phone Contact)

McGrail, John

South Portland Planning

Commission

331 Veranoly Street

Portland, Maine 04103

207/774-9891

McKewen, Thomas

Maryland Department of Natural Resources

Sewer Treatment Plants

Tawes State Office Building

Annapolis, Maryland 21401

301/269-3351

Milunas, J .

Food and Drug Administration

57 th Street, N.E.

Atlanta, Georgia 30323

404/881-3570

Moore, Donald

National Marine Fisheries Service

Building 308, 4700 Avenue U

Galveston, Texas 77550

713/763-1211 Ext. 696

Moulton, Robert

U.S. Army Corps of Engineers

Portland, Oregon

503/221-6437

Mulnick, Jerrold

Food and Drug Administration

Brooklyn, New York

212/965-5071
Murchelano, Robert

National Marine Fisheries Service Oxford Marine Laboratory

Oxford, Maryland 21654

301/226-5771 (Phone Contact)

Murphy, Joellen

National Oceanic and Atmospheric Administration

Office of Coastal Zone Management 2001 Wisconsin Avenue, N.W.

Washington, D.C. 20235

$202 / 634-4249$

Nelson, Gary

National Marine Fisheries Service P.0. Box 4218

Panama City, Florida 32401

Nelson, Jack

Water Development Board

Austin, Texas

515/475-4344

Nelson, John Ray

Bon Secour Fisheries, Inc.

P.0. Box 68

Bon Secour, Alabama 36511

205/943-8511

Nuzzo, Bill

U.S. Environmental Protection Agency, Region I

JFK Federal Building

Boston, Massachusetts 02203

$617 / 223-5137$

Oland, James

U.S. Fish \& Wildlife Service

1805 B Virginia Avenue

Annapolis, Maryland 21401

301/269-5448

Pacheco, Anthony

National Marine Fisheries Service

Middle Atlantic Coast Fisheries

Center

Sandy Hook, New Jersey

201/872-0200 
Pollis, Gerry

U.S. Environmental Protection Agency

Technical Support and Standards Section

6 th and Walnut Street

Curtis Building

Philadelphia, Pennsylvania 19106

Possidento, Mark

Areawide Waste Treatment Management Planning Board

209 Court Street

Middletown, Connecticut 06457

203/347-3700

Presne11, Maynard

Food and Drug Administration

Dauphin Island, Alabama

Pullen, Jack

U.S. Army Corps of Engineers

P.0. Box 4218

Galveston, Texas 32401

713/763-1211

Reed, Dan

Department of Environmental

Protection

Bureau of Water Quality Control

Division of Licensing and

Enforcement

State House

Augusta, Maine 04333

207/289-2591

Rich, Warren

Maryland Department of Natural Resources

Water Resources Administration

Tawes State Office Building

Annapolis, Maryland 19106

301/269-2230
Ricigliano, Anthony

New Jersey Department of Environmental Conservation

P.0. Box 2809

Trenton, New Jersey 08625

Riley, Frank

National Marine Fisheries Service 14 Elm Street

Gloucester, Massachusetts 01930

$617 / 281-3600$

Rihgers, Jon

National Marine Fisheries Service

Regional Planning office

14 Elm Street

Gloucester, Massachusetts 01930

$61 \% / 281-3600$

Rogers, Reginald

U.S. Environmental Protection Agency, Region IV

Ecological Review Section

1421 Peachtree Street

Atlanta, Georgia 30300

Rooney, James

U.S. Environmental Protection Agency, Region II

26 Federal Plaza

New York, New York 10007

Rubelman, Robert

Maryland Fisheries Administration

580 Taylor Avenue

Annapolis, Maryland 21401

$301 / 267-5558$

Sanderson, Albert

Maryland Department of Natural Resources

Maryland Water Resources Administration

Tawes State Office Building

Annapolis, Maryland 21404

301/269-3871 
Schneck, Robert

New York State Department of

Environmental Conservation Marine Resources Sanitation

Building 40

State University of New York Stony Brook, New York 11790

516/751-7900

Schwalm, Darrel1

Food and Drug Administration

109 Holton Street

Winchester, Massachusetts

617/729-5700

Shafer, Harry

Louisiana Department of Wildlife and Fisheries

Seafood Division

400 Royal Street

New Orleans, Louisiana 70130

Shehan, Mason

Maryland Department of Natural

Resources

580 Taylor Avenue

Annapolis, Maryland 21401

301/269-3678

Silva, Jim

U.S. Environmental Protection Agency, Region IV

1421 Peachtree Street, N.E.

Atlanta, Georgia 30300

Silver, Kenneth

Food and Drug Administration

State Program Branch

Brooklyn, New York

212/965-5070
Smith, Don

U.S. Environmental Protection

Agency, Region I

Water Quality Branch

JFK Federal Building

Boston, Massachusetts 02203

617/223-5137

Snyder, Ted

Department of Environmental

Conservation

State University of New York

Building 40

Stony Brook, New York 11790

516/751-7900

Solis, Jim

Maryland Department of Natural

Resources

Water Resources Administration

Planning Division

Tawes State Office Building

Annapolis, Maryland 21404

Sommerset, Ira

Food and Drug Administration

Shellfish Sanitation Branch

Baltimore, Maryland

301/962-4052

St. Amant, Lyle

Louisiana Department of Wildlife

and Fisheries

400 Royal Street, Room 126

New Orleans, Louisiana 70130

504/568-5670

Stapleford, Robert

Virginia State Water Control

Board

P.O. Box 11143

Richmond, Virginia 23220

804/786-1411 
Stott, Robert

Food and Drug Administration

Shellfish Sanitation Branch

Seattle, Washington 98101

206/442-0520

Tolley, Everett

Executive Director

Shellfish Institute of North America

212 Washington Avenue

Baltimore, Maryland 21204

301/821-7860 (Phone Contact)

Tracy, Harry

Department of Ecology

Biological and Chemical

Investigations Section

Olympia, Washington 98504

503/234-3361

Turner, Don

National Marine Fisheries Service

P.0. Box 1229

Galveston, Texas 77553

713/763-1211

Tuttle, Merritt

National Marine Fisheries Service Environmental Assessment Division Portland, Oregon 97208

503/234-3361

Verber, James

Food and Drug Administration

Shellfish Sanitation Branch

Northeast Technical Service Unit

Construction Battalion Center

Building S-26

Davisville, Rhode Island 02854

401/267-2307
Wallace, Gil

U.S. Environmental Protection

Agency, Region IV

Water Enforcement Branch

1421 Peachtree Street

Atlanta, Georgia 30300

Walters, Charles

National Marine Fisheries Service

Coastal Zone Management Assessment

Division

Portland, Oregon 97208

503/234-3361

Whitfield, Bill

Department of Natural Resources

Tallahassee, Florida

904/488-5471

Wiley, Cloyde

Virginia State Health Department

Bureau of Shellfish Sanitation

109 Governor Street

Richmond, Virginia 23219

Willis, James

National Marine Fisheries Service

Beaufort, North Carolina

919/728-4595 (Phone Contact)

Wittig, Ernest

U.S. Army Corps of Engineers

P.0. Box 1229

Galveston, Texas 77553

713/763-1211 Ext. 491

Wong, Edward

U.S. Environmental Protection Agency

$240 \mathrm{Highland}$ Avenue

Lexington, Massachusetts

$617 / 861-6700$ 
Woodfield, William

Woodfield Fish and Oyster Company

Galesville, Maryland 20765

301/867-3421 (Phone Contact)

Woods, Fred

U.S. Environmental Protection Agency, Region VI

Permits Branch

First International Building

1201 Elm Street

Dallas, Texas 75270

Yagel, Gerald

Virginia State Water Control

Board

Division of Special Projects

P.O. Box 902

Kilmarnock, Virginia 22482

804/435-3181

Yerman, Andy

Department of Environmental

Conservation

State University of New York

Building 40

Stony Brook, New York 11790

Zeller, Howard

U.S. Environmental Protection

Agency, Region IV

Enforcement Division

1421 Peachtree street

Atlanta, Georgia 30300

404/326-2211 

Appendix D

BIBLIOGRAPHY

CONTENTS

1. Personal Authors................. D-1

2. Conference and Symposium Proceedings..... D-6

3. Corporate Authors--State Agencies ..... D-7

4. Corporate Authors--Federal Agencies...... D-9

5. Congressional Hearings............. D-17 

Appendix D

BIBLIOGRAPHY

1. Personal Authors

Bastian, R.K., "Municipal Sludge Management," U.S. Environmental Protection Agency, Apri1 1976.

BelI, F.W. and E.W. Canterbery, "An Assessment of the Economic Benefits Which Will Accrue to Commercial and Recreational Fisheries, from Incremental Improvements in the Quality of Coastal Waters," submitted to National Commission on Water Quality, July 1975.

Biggs, R.B., "The Effects of Industrialization on the Estuary," in Estuarine Pollution Control: A National Assessment," U.S. Environmental Protection Agency, report in preparation, 1976.

Brinsfield, R.B. and D.G. Phillips, "Waste Treatment and Disposal from Seafood Processing Plants," Draft Report, University of Maryland Center for Environmental and Estuarine Studies, Reference No. 76-129 HPEL.

Calabrese, A. "How Some Pollutants Affect Embryos and Larvae of American Oyster and Hard-She11 Clam," Mar. Fish. Rey. Vol. 34 (11-12), 1972.

Calabrese, A., R.S. Collier, D.A. Nelson and J.R. MacInnes." The Toxicity of Heavy Metals to Embryos of the American Oyster Crassostrea virginica," Mar. Biol. Vol. 18, 1973.

Calabrese, A. and H.C. Davis. "Effects of 'Soft' Detergents on Embryos and Larvae of the American Oyster (Crassostrea virginica) Proc. Nat. Shellfish Assoc. Vol. 57, 1967.

Calabrese, A. and D.A. Nelson. "Inhibition of Embryonic Development of the Hard Clam, Mercenaria mercenaria, by Heavy Metals," Bull. Env. Contamination and Tox. Vol. II(1), 1974.

Calabrese, A., J.R. MacInnes, D.A. Nelson and J.E. Miller. "Survival and Growth of Bivalve Larvae Under Heavy-Metal Stress," Mar. Biol. 1976.

Carpenter, J.H. and D.L. Macalady, "Chemistry of Halogens in Seawater," in Proceedings of the Conference on the Environmental Impact of Water Chlorination, U.S. Environmental Protection Agency, 1976.

Carter, H.L., "Future Land Requirements to Produce Food For an Expanding Population," in "Perspectives on Prime Lands," U.S. Department of Agriculture, 1975. 
Chapman, C.R., "The Texas Water Plan and Its Effects on Estuaries," in A Symposium on the Biological Significance of Estuaries, Sport Fishing Institute, Washington, D.C., March 1971.

Champ, Michael A., "Nutrient Loading in the Nation's Estuaries," in "Estuarine Pollution Control: A National Assessment," U.S. Environmental Protection Agency, report in preparation, 1976.

Clark, J., "Status of Estuarine Ecosystems in Relation to Sportfish Resources," in "Estuarine Pollution Control: A National Assessment," U.S. Environmental Protection Agency, report in preparation, 1976.

Coastal Plains Center for Marine Development Services, The Marine Newsletter, Vol. 7, No. 6, p. 6, November-December 1976.

Colberg, M.R. and D.M. Windham, "The Oyster Based Economy of Franklin County, Florida," U.S. Dept. of Health, Education, and Welfare, July 1965.

Copeland, B.J., "Effects of Decreased River Flow on Estuarine Ecology," Water Pollution Control Federation Journal, November 1966.

Cowardin, L.M., V. Carter, F.C. Golet, and E.T. LaRoe, "Interim Classification of Wetlands and Aquatic Habitats of the United States,"U.S. Fish and Wildlife Service, March 1976.

Davey, E.W., and D.K. Phelps, "Trace Metals in the Oceans: Problem or No?," in "Estuarine Pollution Control: A National Assessment," U.S. Environmental Protection Agency, report in preparation, 1976.

Davis, H.C. and H. Hidu. Effects of pesticides on embryonic development of clams and oysters and on survival and growth of the larvae. Fish. Bul1. Vol. $67(2), 1969$.

Davis, W.P. and D.P. Middaugh, "A Review of the Impact of Chlorination Processes Upon Marine Ecosystems," in "Estuarine Pollution Control: A National Assessment," U.S. Environmental Protection Agency, report in preparation, 1976.

Ellis, R.H., P.B. Cheney, and D.R. Zoellner, "A Method for Applying Research to Environmental Planning and Management: A Case Study of Issues Important to the Chesapeake Bay Region," Report to the National Science Foundation, May 1973.

Farrington, J.W., "Oil Pollution in the Coastal Environment," in "Estuarine Pollution Control: A National Assessment," U.S. Environmental Protection Agency, report in preparation, 1976.

Feibusch, H.A., "Solid Waste Disposal and its Relationship to Estuarine Pollution," in "Estuarine Pollution Control: A National Assessment," U.S. Environmental Protection Agency, report in preparation, 1976. 
Fletcher, W.W., "The Land Use Implications of the Clean Air Act of 1970 and the Federal Water Pollution Control Act Amendments of 1972,". Library of Congress, Congressional Research Service, NA 9000, 74-176 EP 4 October 1974, Addendum 5, December 1975.

Frost, W.H., "Report of the Committee on Sanitary Control of the Shellfish Industry," Public Health Reports, Supplement No. 53, 1925.

Furfari, S.A., "A Problem Paper on Boat Wastes and the National Shellfish Sanitation Program," U.S. Dept. of Health, Education, and Welfare, January 1968 .

Gallagher, T.P., F.J. Silva, L.W. Olinger, and R.A. Whatley, "Pollution Affecting Shellfish Harvesting in Mobile Bay, Alabama," Federal Water Pollution Control Administration, August 1969.

Galtsoff, P.S., "The American Oyster, Crassostrea virginica," Fishery Bulletin, Vol. 64, 1964.

Geraghty, Miller, Van Der Leeden, and Troise, Water Atlas of the United States, Water Information Center, Inc., 1973.

Glass, S., "Supreme Court Decisions on Impoundment of Water Pollution Control Act Funds," Library of Congress, Congressional Research Service, TD 420 U.S. B, 75-64A (Revised) 572/113A, 24 June 1975.

Gushee, D.E., "An Analysis of P.L. 92-500, The Federal Water Pollution Control Act Amendments of 1972," Congressional Research Service, Library of Congress, November 1972.

Hall, J.R., "Application of Coastal Resource Management and Conservation," U.S. Department of Commerce, National Marine Fisheries Service, Southeast Region.

Hamblet, F.E., W.F. Hill, Jr., E.W. Akin, and W.H. Benton, "The Effect of Turbidity on Viral Depuration by the Oyster, Crassostrea virginica," U.S. Dept. of Health, Education, and Welfare, 1968.

Helz, G.R., "A Preliminary Evaluation of Possible Environmental Hazards Associated with the Present Widespread Use of Chlorine," Research in Aquatic Geochemistry, University of Maryland, 1975.

Hoehn, R.C., C.W. Randa11, and T.J. Grizzard, "The Significance of Nonpoint Sources of Pollution in Shellfish Growing Areas," presented at The 1976 Interstate Seafood Seminar, Rehoboth Beach, Delaware, October 1976.

Hopkins, S.H., J.W. Anderson, and K. Horvath, "The Brackish Water Clam, Rangia cuneata, as Indicator of Ecological Effects of Salinity Changes in Coastal Waters," U.S. Army Corps of Engineers, June 1973. 
Huggett, R.J., M.E. Bender, and H.D. Stone, "Utilizing Metal Concentration Relationships in the Eastern Oysterm (Crassostrea virginica) to Detect Heavy Metal Pollution," Water Research, Vol. 7, pp. 451-460, 1973.

Jensen, L.D., "The Effects of Thermal Discharges upon Aquatic Organisms in Estuarine Waters with Discussion of Limiting Factors," in "Estuarine Pollution Control: A National Assessment," U.S. Environmental Protection Agency, report in preparation, 1976.

Joyce, E.A., Jr., "Florida's Oyster Industry and Current State Research Activities," in Proceedings of a Public Symposium on the Oyster Fisheries of the Gulf States, Biloxi, Mississippi, October 1972.

Kelly, C.B., "The Toxicity of Chlorinated Waste Effluents to Fish and Considerations of Alternative Processes for the Disinfection of Waste Effluents," Virginia State Water Control Board, June 1974.

Kelter, R.J., "Recreation Activities in the Nation's Estuarine Zone," In "Estuarine Pollution Control: A National Assessment," U.S. Environmental Protection Agency, report in preparation, 1976.

Kennish, Michael J., "Monitoring Therma1 Discharges: A Natural Method," Underwater Naturalist, Vol. 9, No. 4, pp. 8-11, June 1976.

Klashman, L.M., K.H. Walker, and R.T. Dewling, "Pollution Control in the Raritan Bay Area," Developments in Water Quality Research, June 1969.

Korringa, P., "Recent Advances in Oyster Biology," Quarterly Review of Biology, Vol. 27, 1952.

Li, Ming-Yu, "Pollution in the Nation's Estuaries Originating from the Agricultural Use of Pesticides," in "Estuarine Pollution Control: A National Assessment," U.S. Environmental Protection Agency, report in preparation, 1976 .

Lincor, J.L., "The Impact of Synthetic Organic Compounds on Estuarine Systems," in "Estuarine Pollution Control: A National Assessment," U.S. Environmental Protection Agency, report in preparation, 1976.

Livingston, R.L., "Resource Management and Estuarine Function with Application to the Apalachicola Drainage System," in "Estuarine Pollution Control: A National Assessment," U.S. Environmental Protection Agency, report in preparation, 1976.

Lumsden, L.L., H.E. Hasseltine, J.P. Leak, and M.V. Veldee, "A Typhoid Fever Epidemic Caused by Oyster-Borne Infection," Public Health Reports, Supplement No. 50, 1925. 
Lynch, M.P., B.L. Laird, N.B. Theberge, and J.C. Jones, eds., "An Assessment of Estuarine and Nearshore Marine Environments," U.S. Dept. of the Interior, March 1976.

Mangum, D.C. and W.F. McIllhenny, "Control of Marine Fouling in Intake Systems - A Comparison of Ozone and Chlorine," in Aquatic Applications of Ozone, W.J. Blogoslawski and R.G. Rice, eds., International Ozone Institute, 1975.

Mason, J.D. and W.R. McLean, "Infectious Hepatitis Traced to the Consumption of Raw Oysters," American Journal of Hygiene, Vol. 75, pp. 1-32, 1961.

Matthiessen, G.C., "A Review of Oyster Culture and the Oyster Industry in North America," Woods Hole Oceanographic Institute, August 1971.

May, E.B., "A Survey of the Oyster and Oyster Shell Resources of Alabama," Alabama Marine Resources Bulletin No. 4, February 1971.

McHugh, J.L., "Estuarine Fisheries: Are They Doomed?" Given at Third Estuarine Research Conference, October 1975.

McKee, J.E., and H.W. Wolf, "Water Quallty Criteria," U.S. Department of Health, Education and Welfare, Public Health Service, 1963.

Mihursky, J.A., "Thermal Discharges and Estuarine Systems," in "Estuarine Pollution Control: A National Assessment," U.S. Environmental

Protection Agency, report in preparation, 1976.

Miller, A.P., "A Study of Pollution of a Shellfish Producing Area," American Journal of Public Health, Vol. 26, No. 6, pp. 970-978, October 1936 .

Morris, J.C., "The Chemistry of Aqueous Chlorine in Relation to Water Chlorination," in Proceedings of the Conference on the Environmental Impact of Water Chlorination, U.S. Environmental Protection Agency, 1976.

Moser, D., "Dig They Must, The Army Engineers, Securing Allies and Acquiring Enemies," Smithsonian, December 1976.

Neilson, B.J., "Water Quality in Small Coastal Basins," Report to Hampton Roads Water Quality Agency, Virginia Institute of Marine Science, August 1976.

Ortolano, L., "Water Resources Decision Making on the Basis of Public Interest," Army Corps of Engineers, February 1975.

Presnell, M.W., "Cooperative Bacterlological Study of Commercial Practices of Oyster Harvesting and Processing in Alabama," U.S. Dept. of Health, Education, and Welfare, November 1970. 
Presnel1, M.W. and C.B. Kelly, "Bacteriological Studies of Commercial Shellfish Operations on the Gulf Coast," U.S. Dept. of Health, Education, and Welfare, 1961.

Rockwood, C.E., et al., "A Management Program for the Oyster Resource in Apalachicola Bay, Florida," Florida State University, 1973.

Roosenburg, William H., "Greening and Copper Accumulation in the American Oyster, Crassostrea virginica, in the vicinity of a Steam Electric Generating Station," Chesapeake Science, Vo1. 10, No. 344, pp. 241-252, September-December 1969.

Santor, J.D., and G.B. Boyd, "Water Pollution Aspects of Surface Contaminants," U.S. Environmental Protection Agency, EPA-R2-72-081, 1972.

Swingle, H.A. and E.A. Hughes, "A Review of the Oyster Pishery of Alabama,?"(Reprint).

von Rumker, R., E.W. Lawless, and A.F. Meiners, "Production, Distribution, Use, and Environmental Impact Potentials of Selected Pesticides," U.S. Environmental Protection Agency, 1974.

Whitfield, W.K., Jr. and D.S. Beaumariage, "Shellfish Management in Apalachicola Bay, Past-Present-Future," Unpublished Report, Florida Dept. of Natural Resource, undated.

2. Conference and Symposium Proceedings

Conference on Aquatic Pollutants With Special Emphasis on Neoplasia, New York Academy of Science, 1976.

Conference in the Matter of Pollution of the Navigable Waters of Mobile Bay and Its Tributaries, U.S. Dept. of the Interior, Mobile, Alabama, January 1970.

Proceedings of the Conference on the Apalachicola Drainage System, Florida Department of Natural Resources, Gainesville, Florida, April 1976.

Proceedings of the Conference on the Environmental Impact of Water Chlorination, U.S. Environmental Protection Agency, 1976.

Proceedings of a Public Symposium on the Oyster Fisheries of the Gulf States, Gulf Coast Research Laboratories, Biloxi, Mississippi, October 1972.

Proceedings of the Sixth National Shellfish Sanitation Workshop, U.S. Department of Health, Education, and Welfare, Food and Drug Administration, February 1968.

Proceedings of the Eighth National Shellfish Sanitation Workshop, U.S. Department of Health, Education, and Welfare, Food and Drug Administration, New Orleans, Louisiana, January 1974.

$$
\text { D-6 }
$$


Proceedings of the Ninth National Shellfish Sanitation Workshop, U.S. Dept. of Health, Education, and Welfare, Food and Drug Administration, Charleston, South Carolina, June 1975.

Symposium on Bacterial Indicators of Potential Health Hazards Associated With Water, American Society for Testing and Materials, Chicago, Illinols, June 28, 1976.

\section{Corporate Authors--State Agencies}

Alabama Water Improvement Commission, "Water Quality Report to Congress for Calendar Year 1974, pursuant to Sec. 305(b), P.L. 92-500, Apri1 1975.

for Calendar Year 1975," pursuant to Sec. 305(b), P.L. 92-500, April 1976.

Town of Apalachicola, Florida, "Sewage Treatment Plan Submitted for Construction Grants Funding by EPA," 1976.

Calffornia State Water Resources Control Board, "Annual Water Qual1ty Inventory Water Year 1975," pursuant to Sec. 305(b), P.L. 92-500, July 1976.

Delaware Department of Natural Resources and Environmental Control, "Delaware 1975 State Water Quality Inventory Report to Congress," pursuant to Sec. 305(b), P.L. 92-500, Apr11 1975.

"Delaware 1976 State Water Quality Inventory Report to Congress," pursuant to Sec. 305(b), P, L. 92-500, July 1976.

Florfda Department of Environmental Regulation, "1976 Water Qual1ty Inventory for the State of Florida," pursuant to Sec. 305(b), P.L. 92-500, April 1976.

State of Hawa11, "Water Quality in the State of Hawal1 Report," pursuant to Sec. 305(b), P.L. 92-500, Apri1 1975.

"Water Quality in the State of Hawal1 Report," pursuant to Sec. 305(b), P.L. 92-500, June 1976.

Interstate Sanitation Commission (New York-New Jersey-Connect1cut), "1975 Report on the Water Pollution Control Activities and the Interstate Air Pollution Program," 1975.

Louislana Advisory Commission on Coastal and Marine Resources, "Loulsiana Government and the Coastal Zone--1972," March 1972. 
Louisiana State Planning Office, "Louisiana Coastal Resources Program Annual Report, FY 75-76," 1976.

Louisiana Coast," June 1976.

, "Unique Ecological Features of the

Louisiana State Planning Office, "FY 1977 State of Louisiana Water Pollution Control Program Plan," 1976.

Loulsiana Stream Control Commission, "State of Louisiana Water Quality Criteria," 1973.

Louisiana Wildlife and Fisheries Commission, "Cooperative Gulf of Mexico Estuarine Inventory and Study," Louisiana, 1971.

State of Maine Department of Enviromental Protection, "Basin Water Quality Management Planning in Maine," Apri1 1975.

, "Maine Water Quality

Status 1975," pursuant to Sec. 305(b), P.L. 92-500, April 1975.

State of Maine Department of Environmental Protection, "Maine Water Quality Status 1976," pursuant to Sec. 305(b), P.L. 92-500, 1976.

State of Maine Department of Environmental Protection and U.S.

Environmental Protection Agency, "Water Quality Standards Summary," September 1972.

Maine Department of Marine Resources, "Sanitary Survey Peport of Scarboro (sic), Maine," 1974 .

State of Maryland, "Maryland Water Quality," pursuant to Sec. 305(b), P.L. 92-500, 1976.

Maryland Department of Natural Resources, "Water Quality Management Plan, Basin Plans," 1976. , "Upper Bay Survey," February 1976.

Mississippi Marine Conservation Commission, "Cooperative Gulf of Mexico Estuarine Inventory and Study, Mississippi," 1973.

New England River Basins Commission, "Long Island Sound Regional Study, People and the Sound," January 1975.

New Hampshire Water Supply and Pollution Control Commission, "State of New Hampshire 1975 National Water Quality Inventory Report to Congress," pursuant to Sec. 305(b), P.L. 92-500, Apri1 1975. 
New Jersey Department of Environmental Protection, "Ocean Pollution Causes and Remedies in the Atlantic Coastal Area," October 1976. , "New Jersey Water

Pollution Control Program for Fiscal Year 1976-1977," 1976.

Inventory," pursuant to Sec. 305(b), P.L. 92-500, May 1976.

New York State Department of Environmental Conservation, Division of Pure Waters, ."1973-74 Boat Basin Study," Unpublished Report.

pursuant to Sec. "New York State Water Quality In
305(b), P.L. 92-500, Apri1 1975. , "New York State Water Quality Inventory Report," pursuant to Sec. 305(b), P.L. 92-500, May 1976.

Oregon Department of Environmental Quality, "Water Quality Control in Oregon, A Status Report," April 1975.

Texas Bureau of Environmental Health, "Oyster Growing Water Evaluations and Conclusions in Connection with Recent Hepatitis Outbreaks--Texas and Georgia," January 1974 .

Virginia State Water Contro1 Board, "1976 Water Quality Inventory," pursuant to Sec. 305(b), P.L. 92-500, April 1976.

1977," Ju1y 1976 .

, "Internal Program Work Plan Fiscal Year

, "Virginia's Shellfish Program Status,"

September 1976 .

, "Water Quality Standards," November 1974.

State of Washington Department of Ecology, "Water Quality Assessment Report," pursuant to Sec. 305(b), P.L. 92-500, June 1975.

State of Washington Department of Natural Resources, Washington Marine Atlas, July 1974 .

4. Corporate Authors--Federal Agencies

U.S. Council on Environmenta1 Quality, "Environmenta1 Impact Statements, An Analysis of Six Years Experience by Seventy Federal Agencies," March 1976. 
, "Environmental Quality--1976,

Seventh Annual Report of the Council on Environmental Quality,

September 1976.

Department of the Army, Corps of Engineers, "1973 Annual Report of the

Chief of Engineers on Civil Works Activities," G.P.0. No. 008-022-00088, 1973.

, "Chesapeake Bay Existing

Conditions Report," NTIS No. AD/A-005 504, December 1973.

, "Chesapeake Bay Future

Conditions Report" (draft) January 1976.

, "Corps of Engineers Interim

Regulations on Permits for Activities in Navigable Waters or

Ocean Waters," Federal Register, Vo1. 4, No. 144, pp. 31320-31344, July 1, 1975.

, "Development of Models for

Prediction of Short-Term Fate of Dredged Material Discharged in the Estuarine Environment," May 1976.

, "Disposal of Dredge Spoil

Problem Idnetification and Assessment and Research Program Development," Technical Report No. H-72-8, 1972.

, "Distribution of Manganese,

Nickel, Zinc, Cadmium, and Arsenic in Sediments and in the Standard Elutriate," NTIS No. AD-A026 355, June 1976.

Department of the Army, Corps of Engineers, "Dredged Material Research Program, Third Annual Report," January 1976.

, "Ecological Evaluation of

Proposed Discharge of Dredged or Fill Material into Navigable Waters," Miscellaneous Paper D-76-17, May 1976.

, "Final Environmental Statement

on Apalachicola, Chattahoochee, and Flint Rivers, Alabama, Florida, and Georgia (Operation and Maintenance)," April 1976.

, "Draft Environmental Impact Statement for Fire Island to Montauk Point, New York Beach Frcsion Control and Furrican Protection Project," March 1976.

, "Final Environmental Impact

Statement on the Grays Harbor and Chehalis River Navigation Project, Operation and Maintenance," June 1975. 
"Final Environmental Impact

Statement on the Maintenance of Great South Bay Channel and Patchogue River and Long Island Intercoastal Waterway, New York Navigation Projects," December 1975.

, "Final Enviromental Impact

Statement on the Port of Grays Harbor/Kaiser Steel Corporation Permit Application, No. 071-OYB-1-002533, Hoquiam, Washington," July 1976.

, "Draft Environmental Statement

of the Theodore Ship Channel and Barge Channel Extension, Mobile Bay, Alabama," March 1976.

, "Final Environmental Statement

on Wicomico River (East) Operation and Maintenance Dredging Project, Wicomico River, Maryland," January 1976.

, "Final Environmental Impact

Statement on the Willapa River and Harbor Navigation Profect-Washington," January 1976.

, "First Steps Toward Achieving Disposal Area

Reuse," NTIS No. ADA-024 646, April 1976.

, "Identification of Objectionable Environmental

Conditions and Issues Associated with Confined Disposal Areas," NTIS

No. AD/A-000 895, September 1974.

Department of the Army, Corps of Engineers, "Identification of

Relevant Criteria and Survey of Potential Application Sites for

Artificial Habitat Creation," October 1976.

, "Research Study on the Effect

of Dispersion, Settling, and Resedimentation on Migration of

Chemical Constituents During Open-Water Disposal of Dredged

Materials," NTIS No. AD-A022 144, February 1976.

or: Chesapeake Bay," March 1975.

, "Impact of Tropical Storm Agnes

, "Status Report on Environmental

Evaluations, Trinity River Project, Texas," 1975.

, "Techniques for Reducing

Turbidity Associated with Present Dredging Procedures and Operations," May 1976. 
"Water Resources Development by

the U.S. Army Corps of Engineers in Washington," 1975.

U.S. Department of Commerce, Bureau of the Census, "Statistical Abstract of the United States," 1975.

U.S. Department of Commerce, National Marine Fisheries Service, "Application of Coastal Resource Management and Conservation," J.R. Ha11, SE Region.

, "Basic

Economic Indicators, Clams, 1947-74," Current Fisheries Statistics No. 6794, June 1975.

tive Gulf of Mexico Estuarine Inventory and Study, Florida,"

NOAA TR NMFS CIRC-368, November 1972.

tive Gulf of Mexico Estuarine Inventory and Study--Texas,"

"Coopera-

NOAA TR NMFS CIRC-393, September 1975.

, "Fisheries

of the United States, 1975," Current Fishery Statistics No. 6900, March 1976.

Statistics of the United States, 1971," Statistical Digest

"Fishery

No. 65, 1971.

for Fisheries Program Activities, 1976," October 1976.

"Grant-in-aid

U.S. Department of Commerce, National Marine Fisheries Service, "Louisiana Landings, Annual Summary 1975," Current Fisheries Statistics No. 6922, October 1976.

of Fish and Shellfish with Anoxic Bottom Water in the Middle

Atlantic Bight," Red Flag Report, September 1976.

, "Report of

the National Marine Fisheries Service for the Calendar Year 1975," July 1976.

States Marine Fishery Resource," MARMAP Contribution No. 1 ,

"The United March 1974.

U.S. Department of Commerce, National Oceanic and Atmospheric Administration,

"Report to the Congress on Coastal Zone Management, July 1974

through June 1975," April 1976.

$$
\mathrm{D}-12
$$


"Report to the Congress on Ocean Dumping Research, January through December 1975," June 1976.

"Report to the Congress on Ocean Pollution, Overfishing, and Offshore Development, July 1974 through June 1975," June 1976.

U.S. Department of Commerce, Office of the Secretary, "A Marine Fisheries Program for the Nation," Statement by Elliot M. Richardson, Secretary of Commerce, July 1976.

U.S. Department of Commerce, Office of Coastal Zone Management, "Living Coastal Resources - a Coastal Zone Management Technical Assistance Documient," July 1976.

U.S. Environmental Frotection Agency, "Chemical and Biological Survey of Liberty Bay, Washington," EPA-910/9-76-029, September 1976.

$1975-76, " 1976$. , "Clean Water, Report to Congress

, "Development Document for Effluent Limitations Guidelines and New Source Performance Standards for the Fish Meal, Salmon, Bottom Fish, Clam, Oyster, Sardine, Scallop, Herring, and Abalone Segment of the Canned and Preserved Fish and Seafood Processing Industry Point Source Category," September 1975.

, "Draft Environmental Impact Statement on the Ocean Dumping of Sewage Sludge in the New York Bight," February 1976.

, "Draft Environmental Impact Statement on Wastewater Collection and Treatment Facilities for Scarborough, Maine," December 1975.

, "Environmental Impact Statement on Wastewater Treatment Facilities Construction Grants for the Lower Raritan River Basin and for the South Shore of Raritan Bay," June 1973.

U.S. Environmental Protection Agency, "EPA Enforcement, A Progress Report, December 1974 to December 1975," 1976.

Activity Report," 1976.

, "EPA Formal Report System's State 
, "Estuarine Pollution--A National

Survey," report in preparation, 1976.

, "Fina1 Revisions of Regulations and

Criteria," Federa1 Register, Vo1. 42, p. 2462, January 11, 1977.

, "Draft Guidelines for state and

Area-wide Water Quality Management Program Development," February 1976.

, "National Pollutant Discharge

Elimination System," Federal Register, Vo1. 41, No. 134, p. 28493, July 1976.

"Nationa1 Shellfish Register of

Classified Estuarine Waters, 1974," December 1975.

, "National Water Quality Inventory,

1974 Report to Congress," EPA-440/9-7.4-001, 1974

, "National Water Quality Inventory, 1975 Report to Congress," EPA-440/9-75-014, 1975.

, "Ocean Dumping in the United

States-- 1976," June 1976.

, "Pollution Control in the U.S.--Some

Recent Accomplishments, Report to the Deputy Administrator,"

November 1976.

, "Protection of Shellfish Waters,"

Technical Bulletin, EPA-430/9-74-010, July 1974.

, "Quality Criteria for Water,"

EPA-440/9-76-023, 1976.

, "State Continuing Planning Process

Handbook," December 1975.

, "Summary Tabulation of Selected EPA

Activities Concerning Toxic Chemicals," Apri1 1976.

, "Transition Papers to Incoming

Carter Administration on Areas of Agency Jurisdiction, January 1977.

, "Water Quality Analysis of the

Raritan-Lower Bay System" December 1974.

Bay, Florida," June 1975.

, "Water Quality Study, St. Andrew

D-14 
U.S. Environmental Protection Agency, "Water Quality Inventory 1974, Southeastern United States," June 1975.

FY 1977," undated.

, "Water Quality, Regional Guidance,

U.S. General Accounting Office, Comptroller General of the United States, "The Coastal Zone Management Program, An Uncertain Future,"

December 1976.

"Federal Agencies Administering Programs Related to Marine Science Activities and Ocean Affairs," Report to Congress, February 1975.

"Implementing the National Water Pollution Control Permit Program: Progress and Problems," Report to House Committee on Public Works and Transportation, Subcommittee on Investigations and Review, February 1976.

"The Need for a National Ocean Program and Plan," Report to Congress, October 1975.

Problems and Progress in Regulating Ocean Dumping of Sewage Sludge' and Industrial Wastes," January 1977.

"Protecting the Consumer from Potentially Harmful Shellfish (Clams, Mussels, and Oysters)," Report to Congress, March 1976.

"Research and Demonstration Programs to Achieve Water Quality Goa1s: What the Federal Government Needs to Do," Report to Congress, February 1975.

U.S. Department of Health, Education, and Welfare, Food and Drug Administration, "Bacteriological Study of Waters and Soft Shell

Clams, Mya arenaria, in the Miles River, Maryland," July 1973.

September 1976.

New York, March 1974," June 1974.

, "National Register of Shellfish Production Areas," 1966. 
U.S. Department of Health, Education, and Helfare, Food and Drug Administration, "National Shellfish Register of Classified Estuarine Waters," FDA 74-2013, 1971. "National Shellfish Sanitation Program Manual of
Operations 1965.

, "National Shellfish Safety Frogram, Proposed Rulemeking," Federa1 Register, Vo1. 40, No. 119, June 1975.

Island, Virginia," July 1970.

U.S. Department of the Interior, Bureau of Reclamation, "Water and Land Resource Accomplishments, 1974," October 1975.

U.S. Department of the Interior, Fish and Wildife Service, "An Assessment of Estuarine and Nearshore Marine Environments," SRAMSOE No. 93, March 1976.

Our Fish and Wildife Heritage, Annual Report--FY 1975, U.S. Fish and Wildife Service," undated.

, "Nationa1

Estuarine Study," January 1970.

U.S. Department of the Interior, Geological Survey, "Outer Continertal Shelf Statistics, Calendar Year 1975," June 1976.

U.S. Department of the Interior, Office of Water Research and Technology, "Annual Report 1975," undated.

Secretary of the Interior, "The National Estuarine Pollution Study," Report to Congress, Senate Document No. 91-58, March 1970.

National Commission on Water Quality, "Public Law 92-500, Water Quality Analysis and Environmental Impact Assessment Technical Report," NTIS No. PB-252 167, Apri1 1976.

Staff Draft Report, November 1975.

"Draft Repcrt to Congress,"

, "Report to Congress by the National Comission on Water Quality," March 1976. 
National Commission on Water Quality, "Draft Report by Environmental Quality Systems, Inc.," 1976.

, "Water Policies for the Future," Report to the President and the Congress of the United States, G.F.C. No. 5248-00006, June 1973.

, 'Water Quality Analysis and Environmental Impact Assessment of P.L. 92-500, Technical Volume," Staff Draft Report, January 1976.

U.S. Department of Transportation, "Activities Relating to the Deepwater Port Act of 1974, Report to Congress, Fiscal Year 1975," January 1976.

U.S. Water Resources Council, "1975 Water Assessment Problem Identification (Draft Report)," June 1976.

5. Congressicral Hearings

Outen, R., "Statements on Behalf of Natural Resources Defense Council, Hearings on Implementation of the Section 404 Permit Program," U.S. Senate Committee on Public Works, July 1976.

Speth, G., "Statements on Behalf of Natural Resources Defense Council and other Organizations, Hearings on Implementation of the Section 404 Permit Program," U.S. Senate Committee on Public Works, July 28, 1976.

Taft, P.R. (Assistant Attorney General, Land and Resources Division), "Statements Concerning P.I. 92-500," U.S. Senate Committee on Public Norks, July 27, 1976.

U.S. Department of Interior, Fish and Wildlife Service, "Hearings on Estuarine Areas," House Merchant Marine and Fisheries Subcomittee on Fisheries and Wildlife Conservation, March 1967. 


PENN STATE UNIVERSITY LIBRARIES

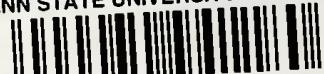
A000070941180

NOAA--S/T $77-2754$

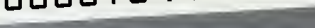

